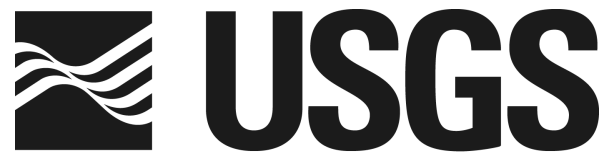

science for a changing world

WASHINGTON STATE
DE PART MEN T O F

E C 0 L 0 G Y

\title{
Grays Harbor Wave Refraction Experiment 1999: \\ Data Report
}

Guy Gelfenbaum, Christopher R. Sherwood, Laura A. Kerr, and Keith Kurrus

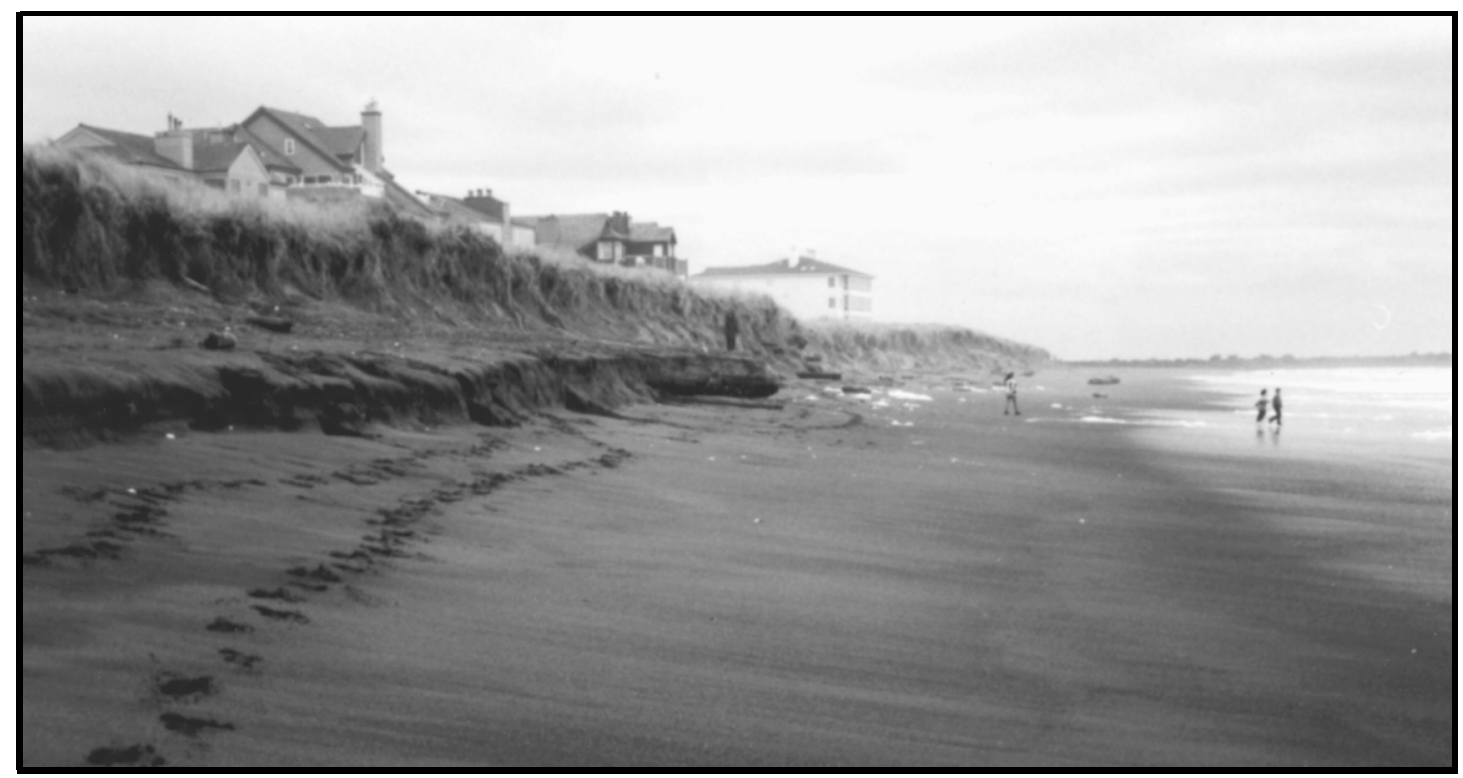

Open-File Report 00-404

November 2000

Prepared in Cooperation with

Washington State Department of Ecology

U.S. Department of the Interior

U.S. Geological Survey 



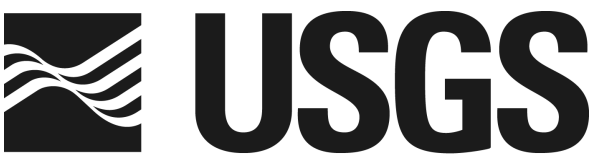

science for a changing world

WASHINGTON STATE

$\mathbf{E} \mathbf{C}^{\mathrm{O}} \mathbf{0} \mathbf{O}^{\mathrm{Y}}$

\section{Grays Harbor Wave Refraction Experiment 1999: \\ Data Report}

Guy Gelfenbaum ${ }^{1}$, Christopher R. Sherwood ${ }^{1}$, Laura A. Kerr ${ }^{1}$, and Keith Kurrus ${ }^{2}$

Open-File Report 00-404

November 2000

\section{Prepared in Cooperation with Washington State Department of Ecology}

This report is preliminary and has not been reviewed for conformity with the U.S. Geological Survey editorial standards or with the North American Stratigraphic code. Any use of trade, firm, or product names is for descriptive purposes only and does not imply endorsement by the U.S. Government.

U.S. Department of the Interior

U.S. Geological Survey

${ }^{1}$ U.S. Geological Survey, Menlo Park, CA

2 Evans-Hamilton, Inc., Seattle, WA 
Cover Photograph: Ocean Shores, Washington is located on the north side of Grays Harbor inlet. This photograph was taken in 1996.

2nd Printing February 2001 


\section{SUMMARY}

The Southwest Washington Coastal Erosion Study (SWCES) is a five-year multidisciplinary investigation of the coastal region between Tillamook Head, Oregon and Point Grenville, Washington cosponsored by the U. S. Geological Survey and the Washington State Department of Ecology. The Grays Harbor Wave Refraction Experiment was a series of measurements made near the entrance to Grays Harbor between October and December, 1999. The objectives of the measurements are (1) to calibrate and verify numerical models of wave transformation (primarily refraction and shoaling), and (2) to provide information about bottom sediment size, waves, currents, and suspended-sediment concentrations for use in calculations of sediment transport. This report describes data obtained during that experiment.

Six tripods were deployed near the entrance to Grays Harbor, Washington. These tripods contained pressure sensors, acoustic doppler profilers, acoustic doppler velocimeters, and optical backscatter sensors to measure waves, tides, currents, and suspended-sediments. Data were recovered from all instruments except one damaged at the northern shallow site during the first deployment (Site NS).

Several observations should be noted with any interpretation of these raw data.

1) The tripod at Site SS was apparently picked up and placed back on the bottom by unknown parties between 1618 and 1842 GMT on October 18, 1999 (during the first deployment). There was no apparent damage to the tripod, but it may have been moved slightly, and new coordinates were not determined during recovery.

2) The pressure sensor data associated with the acoustic doppler profiler at Site SD are suspiciously erratic at the beginning of Deployment 1 , suggesting that the sensor port may have been partially blocked. The data appear correct beginning at 1622:30 October 8 (profile 284).

3) Wave directions (not presented in this report) estimated from Site MD during the second deployment differ by about $16^{\circ}$ from the expected direction, suggesting the possibility of compass error or miscalibration.

4) The measured distance between the acoustic doppler velocimeter (ADV) sensor and the sea floor changed (and generally decreased) at all 5 ADV sites during each deployment, suggesting that the tripod was either being worked into the bed (more likely) or that net deposition of sediment occurred (less likely). Estimates of sensor elevation are particularly important for interpretation of current and suspended-sediment data from the ADV and associated optical backscatter sensor (OBS).

Data and conclusions provided in this open-file report are preliminary and may contain errors that remained undetected in routine quality-control checks. Future analysis may modify some values. Therefore, these data are provided to and accepted by the user with any accompanying faults and defects. Any person or entity that relies upon information generated by or obtained herein does so at their own risk. 


\section{TABLE OF CONTENTS}

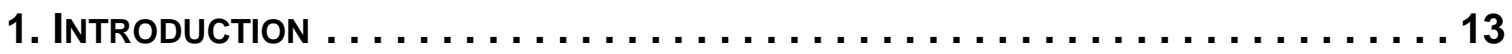

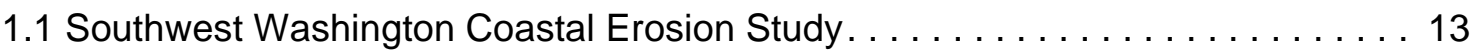

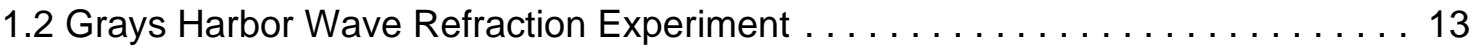

2. Data Collection Methods . . . . . . . . . . . . . . . . . . . 15

2.1 Experiment Overview ................................... 15

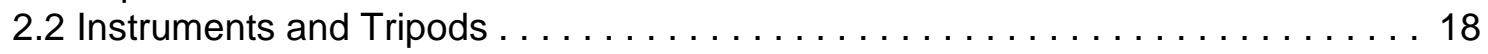

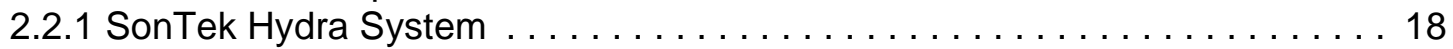

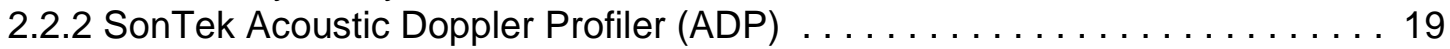

2.2.3 Sea-Bird Seagauge Wave and Tide Recorder .................. 20

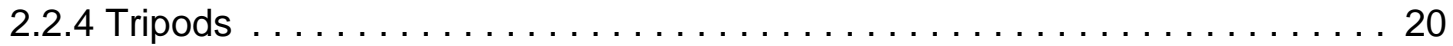

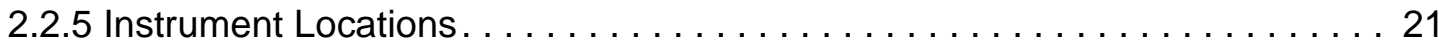

2.2.6 Optical Backscatter Sensor Calibrations..................... 26

2.3 Bottom Sediment Samples . . . . . . . . . . . . . . . . . . . . . . . 26

2.4 CTD Profiles . . . . . . . . . . . . . . . . . . . . . . . . . 27

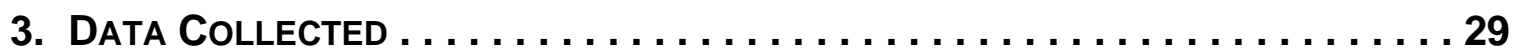

3.1 Bottom Sediment Samples . . . . . . . . . . . . . . . . . . . . . . . . . 29

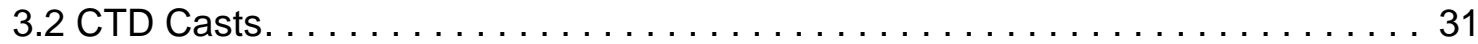

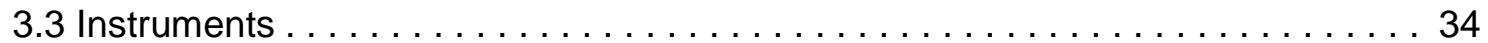

4. Preliminary Observations from the Data . . . . . . . . . . . . . 99

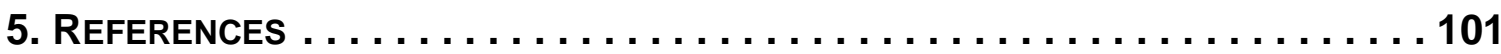

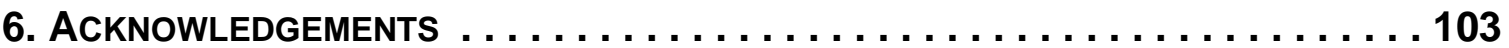

APPENDIX A. Field Logs. . . . . . . . . . . . . . . . . . . . . . . . . . . . . . 105

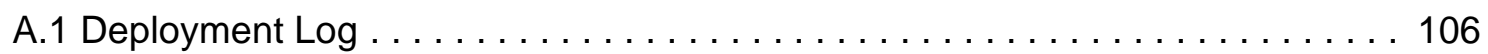

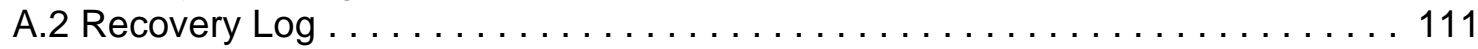

APPENDIX B. DESCRIPTION OF FILES ON CD-ROMS AND CONTENTS OF

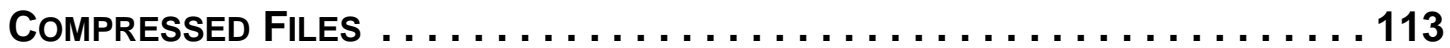

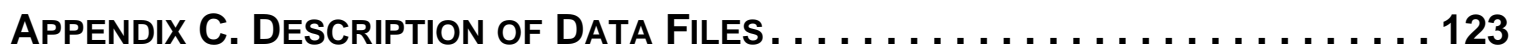

C.1 SonTek Hydra System . . . . . . . . . . . . . . . . . . . . . . . . . . . 124

C.2 Sea-Bird Seagauge Wave and Tide Recorder . . . . . . . . . . . 128

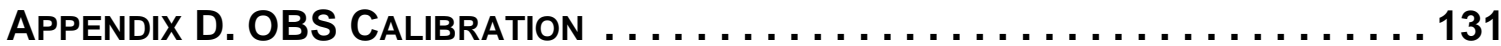

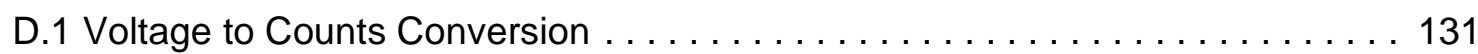

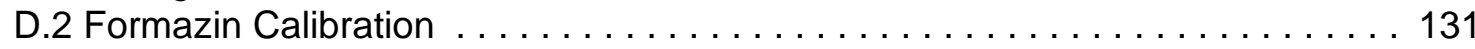




\section{LIST OF FIGURES}

Figure 1. Chart of the study area near Grays Harbor, Washington showing sites where USGS tripods were deployed for the wave refraction experiment. . . . . . 16

Figure 2. Time series of data collected by the Grays Harbor, WA CDIP buoy during the time of the Grays Harbor Wave Refraction Experiment.. . . . . . . . . . . 17

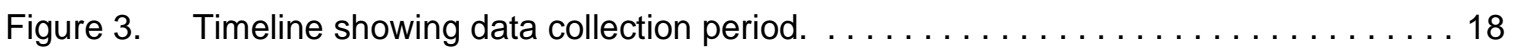

Figure 4. Schematic drawing of tripods deployed at Sites ND, NS, MD, SD, and SS. . . . 21

Figure 5. Photograph of tripods deployed at Sites MS, ND, and NS (left to right). . . . . . 22

Figure 6. Photograph showing relative placement of Hydra data logger and ADP on tripod. . 23

Figure 7. Photograph showing relative placement of Paros and ADVOcean on tripod. . . . 23

Figure 8. Photograph showing relative placement of ADV and OBS on tripod. . . . . . . . 24

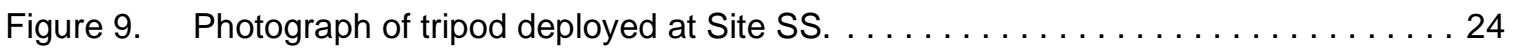

Figure 10. Schematic illustration of tripods deployed at Sites ND and SD, showing path

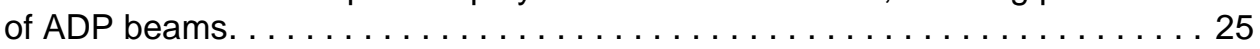

Figure 11. Photograph of tripod used to deploy the Sea-Bird Seagauge wave/tide recorder

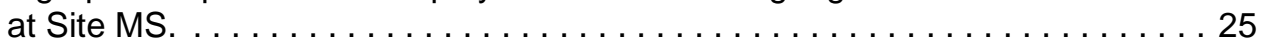

Figure 12. Grain size distribution histograms for the six sites $\ldots \ldots \ldots \ldots \ldots \ldots \ldots \ldots . \ldots \ldots$

Figure 13. Profiles of salinity, temperature, and density measured at Sites ND and NS on

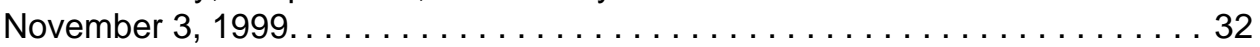

Figure 14. Profiles of salinity, temperature, and density measured at Site MS on November 3, 1999, and Sites MD, SD, and SS on November 27, 1999. . . . . . 33

Figure 15. Time series of east (positive eastward), north (positive northward), and vertical (positive up) velocity components, turbidity, and distance to the bottom from data collected by the ADV at Site ND. . . . . . . . . . . . 42

Figure 16. Time series of signal strength collected for each ADV receiver at Site ND. . . . 43

Figure 17. Time series of signal correlation for ADV receivers at Site ND. . . . . . . . . . . 44

Figure 18. Time series of heading, pitch, roll, and distance to the bottom from data collected by the ADV at Site ND. . . . . . . . . . . . . . . 45

Figure 19. Time series of pressure, temperature, speed, and direction from data collected by the ADV at Site ND. . . . . . . . . . . . . . 46

Figure 20. Time series of the response of the OBS, turbidity, suspended sediment concentration, and distance to the bottom for Site ND. . . . . . . . . . . . 47

Figure 21. Time series of low-pass filtered velocity and cumulative alongshore and

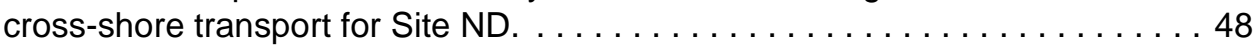

Figure 22. Time series of suspended sediment flux and cumulative alongshore and cross-shore suspended sediment transport for Site ND. . . . . . . . . 49

Figure 23. Time series of significant wave height, mean period, pressure, and temperature from data collected by the ADP at Site ND. . . . . . . . 50

Figure 24. Time series of heading, pitch, and roll from data collected by the ADP at

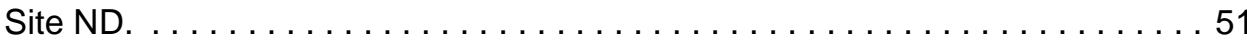


Figure 25. Time series of east (positive eastward), north (positive northward), and vertical (positive up) velocity components, speed, and direction in cell 1

(2.25 mab) from data collected by the ADP at Site ND . . . . . . . . . . 52

Figure 26. Time series of east (positive eastward), north (positive northward), and vertical (positive up) velocity components, speed, and direction in cell 2

(2.75 mab) from data collected by the ADP at Site ND. . . . . . . . . . 53

Figure 27. Time series of east (positive eastward), north (positive northward), and vertical (positive up) velocity components, speed, and direction in cell 20

(11.75 mab) from data collected by the ADP at Site ND. . . . . . . . . . . 54

Figure 28. Time series of east (positive eastward), north (positive northward), and vertical (positive up) velocity components, speed, and direction in cell 36

(19.75 mab) from data collected by the ADP at Site ND. . . . . . . . . . 55

Figure 29. Time series of low-pass filtered velocity for several ADP cells at Site ND. . . . . 566

Figure 30. Time series of cumulative alongshore and cross-shore transport for several

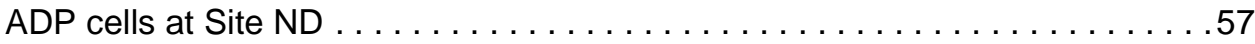

Figure 31. Progressive vector diagram of currents at Site ND. $\ldots \ldots \ldots \ldots \ldots \ldots \ldots \ldots 8$

Figure 32. Time series of east (positive eastward), north (positive northward), and vertical (positive up) velocity components, turbidity, and distance to the bottom from data collected by the ADV at Site NS . . . . . . . . . . . . . 59

Figure 33. Time series of signal strength collected for each ADV receiver at Site NS.. . . . . 60

Figure 34. Time series of signal correlation for ADV receivers at Site NS . . . . . . . . 61

Figure 35. Time series of heading, pitch, roll, and distance to the bottom from data collected by the ADV at Site NS. . . . . . . . . . . . . . . . 62

Figure 36. Time series of pressure, temperature, speed, and direction from data collected by the ADV at Site NS. . . . . . . . . . . . . . . . 63

Figure 37. Time series of low-pass filtered velocity and cumulative alongshore and cross-shore transport for Site NS. . . . . . . . . . . . . . . 64

Figure 38. Time series of east (positive eastward), north (positive northward), and vertical (positive up) velocity components, turbidity, and distance to the bottom from data collected by the ADV at Site MD. . . . . . . . . . . . . 65

Figure 39. Time series of signal strength collected for each ADV receiver at Site MD. . . . . 66

Figure 40. Time series of signal correlation for ADV receivers at Site MD. . . . . . . . 67

Figure 41. Time series of heading, pitch, roll, and distance to the bottom from data collected by the ADV at Site MD. . . . . . . . . . . . . . 68

Figure 42. Time series of pressure, temperature, speed, and direction from data collected by the ADV at Site MD. . . . . . . . . . . . . . . . 69

Figure 43. Time series of the response of the OBS, turbidity, suspended sediment

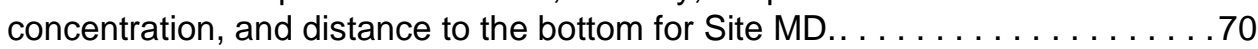

Figure 44. Time series of low-pass filtered velocity and cumulative alongshore and

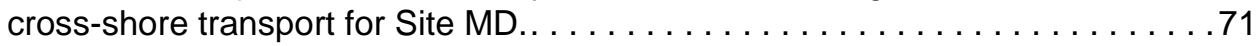

Figure 45. Time series of suspended sediment flux and cumulative alongshore and cross-shore suspended sediment transport for Site MD.. . . . . . . . . . 72

Figure 46. Time series of east (positive eastward), north (positive northward), and vertical (positive up) velocity components, turbidity, and distance to the bottom from data collected by the ADV at Site SD . . . . . . . . . . . . . . . . . 73 
Figure 47. Time series of signal strength collected for each ADV receiver at Site SD. . . . . 74

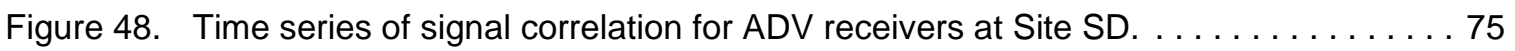

Figure 49. Time series of heading, pitch, roll, and distance to the bottom from data

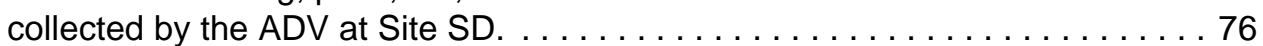

Figure 50. Time series of pressure, temperature, speed, and direction from data

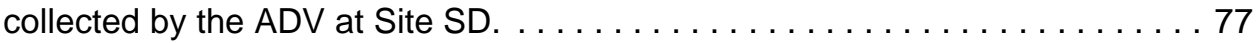

Figure 51. Time series of the response of the OBS, turbidity, suspended sediment

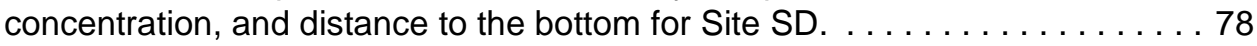

Figure 52. Time series of low-pass filtered velocity and cumulative alongshore and

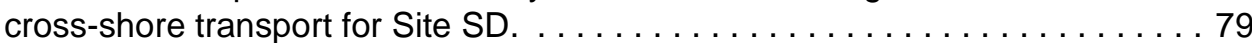

Figure 53. Time series of suspended sediment flux and cumulative alongshore and cross-shore suspended sediment transport for Site SD . . . . . . . . 80

Figure 54. Time series of significant wave height, mean period, pressure, and temperature from data collected by the ADP at Site SD . . . . . . .

Figure 55. Time series of heading, pitch, and roll from data collected by the ADP at

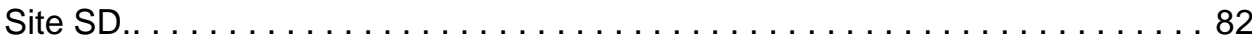

Figure 56. Time series of east (positive eastward), north (positive northward), and vertical (positive up) velocity components, speed, and direction in cell 1 (2.25 mab) from data collected by the ADP at Site SD . . . . . . . . . 83

Figure 57. Time series of east (positive eastward), north (positive northward), and vertical (positive up) velocity components, speed, and direction in cell 2 (2.75 mab) from data collected by the ADP at Site SD . . . . . . . . . . . . 84

Figure 58. Time series of east (positive eastward), north (positive northward), and vertical (positive up) velocity components, speed, and direction in cell 20 (11.75 mab) from data collected by the ADP at Site SD . . . . . . . . . 85

Figure 59. Time series of east (positive eastward), north (positive northward), and vertical (positive up) velocity components, speed, and direction in cell 36 (19.75 mab) from data collected by the ADP at Site SD . . . . . . . . 86

Figure 60. Time series of low-pass filtered velocity for several ADP cells at Site SD . . . . 87

Figure 61. Time series of cumulative alongshore and cross-shore transport for several

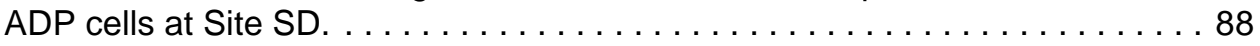

Figure 62. Progressive vector diagram of currents at Site SD. $\ldots \ldots \ldots \ldots \ldots \ldots \ldots$

Figure 63. Time series of east (positive eastward), north (positive northward), and vertical (positive up) velocity components, turbidity, and distance to the bottom

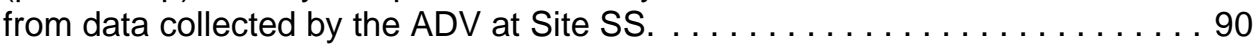

Figure 64. Time series of signal strength collected for each ADV receiver at Site SS. . . . . 91

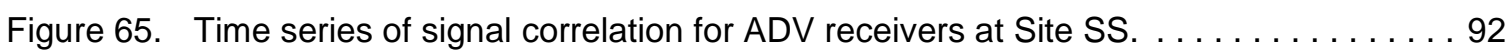

Figure 66. Time series of heading, pitch, roll, and distance to the bottom from data collected by the ADV at Site SS. . . . . . . . . . . . . . 93

Figure 67. Time series of pressure, temperature, speed, and direction from data

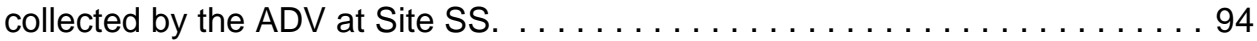

Figure 68. Time series of the response of the OBS, turbidity, suspended sediment concentration, and distance to the bottom for Site SS. . . . . . . . . . . . 95

Figure 69. Time series of low-pass filtered velocity and cumulative alongshore and cross-shore transport for Site SS. 
Figure 70. Time series of suspended sediment flux and cumulative alongshore and cross-shore suspended sediment transport for Site SS . . . . . . . . . .97

Figure 71. Time series of pressure and temperature data collected by the Seagauge at Site MS. . . . . . . . . . . . . . . . . . . 


\section{LIST OF TABLES}

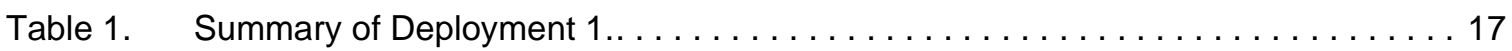

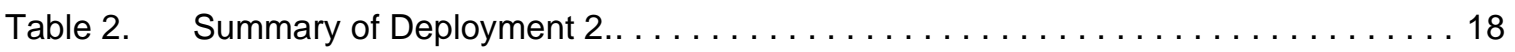

Table 3. SonTek Hydra system serial numbers and sampling parameters. . . . . . . . . 19

Table 4. SonTek ADP serial numbers and sampling parameters. $\ldots \ldots \ldots \ldots \ldots \ldots \ldots$

Table 5. Sea-Bird Seagauge serial number and sampling parameters for Site MS.. . . . . . 20

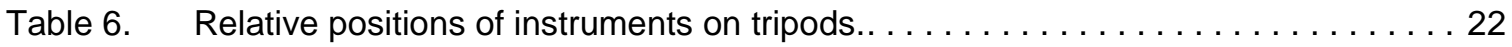

Table 7. Location of bottom sediment grab samples and comments from field notes. . . . 26

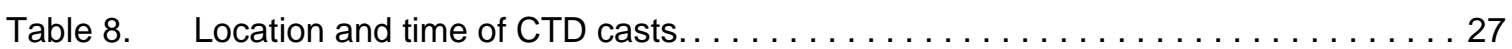

Table 9. Results of grain size analysis reported as weight percent at $1 / 4$ phi intervals

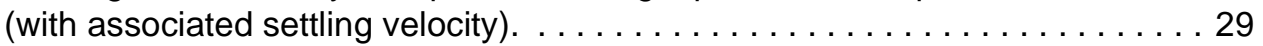

Table 10. Results of grain-size statistical analysis (phi, unless otherwise noted) . . . . . 31

Table 11. Date, time, and burst number of first and last valid data record for each system deployed. . . . . . . . . . . . . . . . . . . 34

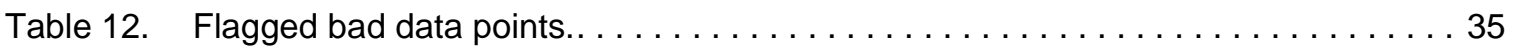

Table 13. Data statistics from Deployments 1, 2, and the entire deployment. . . . . . . 36

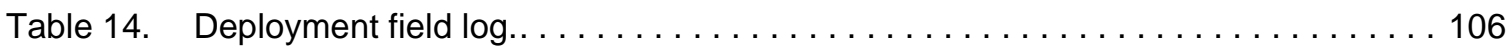

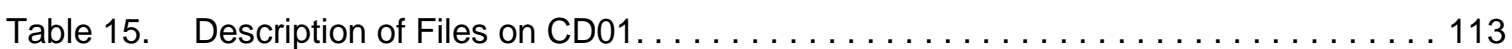

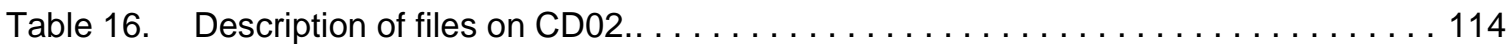

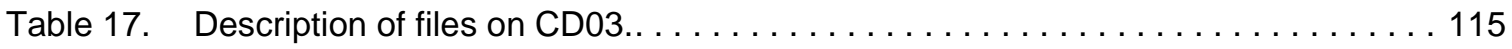

Table 18. Contents of ndadp01.zip, zipped ADP data converted to ASCIl files,

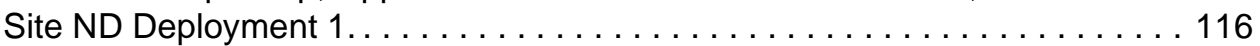

Table 19. Contents of ndadv01.zip, zipped ADV data converted to ASCIl files,

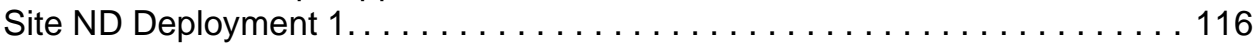

Table 20. Contents of mdadv01.zip, zipped ADV data converted to ASCII files, Site MD Deployment $1 \ldots \ldots \ldots \ldots \ldots \ldots \ldots \ldots \ldots \ldots \ldots \ldots \ldots \ldots \ldots \ldots \ldots$

Table 21. Contents of mssb01.zip, zipped Seagauge data converted to ASCII files, Site MS Deployment $1 \ldots \ldots \ldots \ldots \ldots \ldots \ldots \ldots \ldots \ldots \ldots \ldots \ldots \ldots$

Table 22. Contents of sdadp01.zip, zipped ADP data converted to ASCIl files,

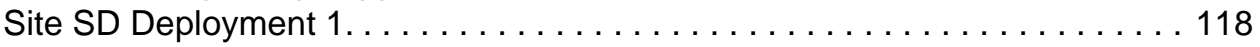

Table 23. Contents of sdadv01.zip, zipped ADV data converted to ASCIl files,

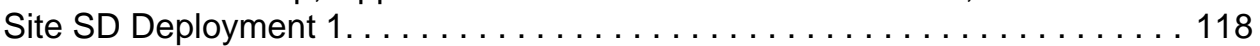

Table 24. Contents of ssadv01.zip, zipped ADV data converted to ASCII files, Site SS Deployment $1 \ldots \ldots \ldots$. . . . . . . . . . . . . . . . . . . . . . . 119

Table 25. Contents of ndadp02.zip, zipped ADP data converted to ASCII files,

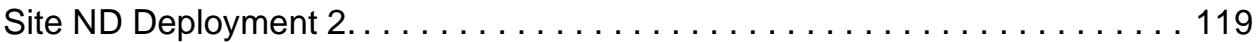

Table 26. Contents of ndadv02.zip, zipped ADV data converted to ASCIl files,

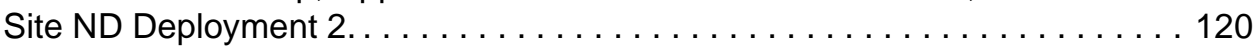

Table 27. Contents of nsadv02.zip, zipped ADV data converted to ASCIl files, Site NS Deployment 2. . . . . . . . . . . . . . . . . . . . . . . . . . . . 120 
Table 28. Contents of mdadv02.zip, zipped ADV data converted to ASCII files,

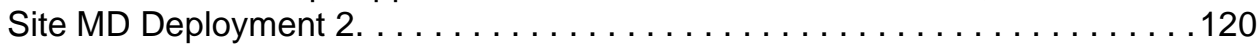

Table 29. Contents of mssb02.zip, zipped Seagauge data converted to ASCII files,

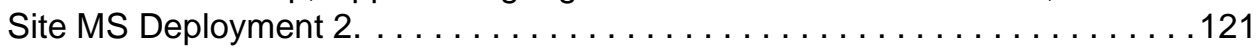

Table 30. Contents of sdadp02.zip, zipped ADP data converted to ASCII files,

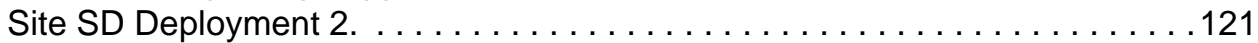

Table 31. Contents of sdadv02.zip, zipped ADV data converted to ASCII files,

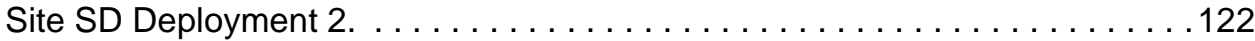

Table 32. Contents of ssadv02.zip, zipped ADV data converted to ASCIl files,

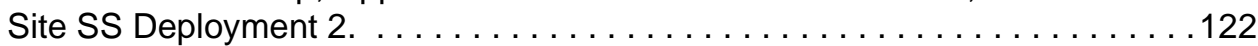

Table 33. Column headers for ADV .HDR files (except Site NS) . . . . . . . . . . . . . 124

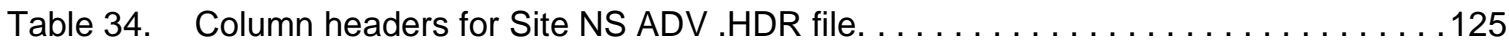

Table 35. Column headers for ADV .TS files (except Site NS) - time series. . . . . . . . . 126

Table 36. Column headers for Site NS ADV .TS file - time series. . . . . . . . . . . . . . 126

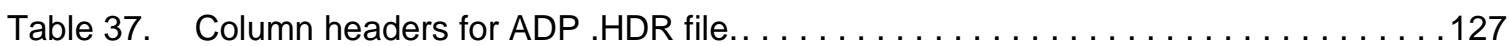

Table 38. Column headers for ADP .VE/.VN/.VU files - east (magnetic-eastward positive) / north (magnetic-northward positive) /vertical (up positive)

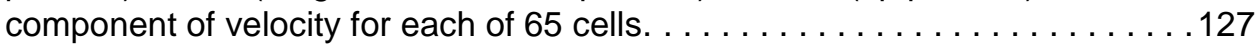

Table 39. Column headers for ADP .SD1/.SD2/.SD3 Files - standard deviation of east / north /vertical component of velocity for each of 65 cells. . . . . . . . . . . 127

Table 40. Column headers for ADP .A1/.A2/.A3 files - amplitude of signal strength for

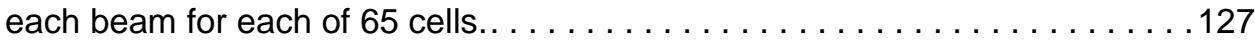

Table 41. Column headers for ADP .SN1/.SN2/.SN3 files - signal to noise ratio for

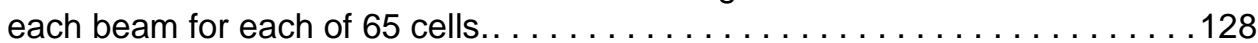

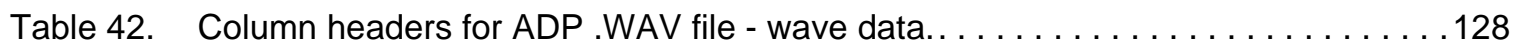

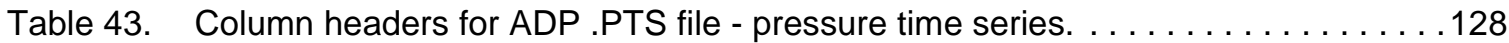

Table 44. Column headers for Seagauge .TID files- tide data. . . . . . . . . . . . . . . . . 128

Table 45. Column headers for Seagauge .WB files - wave burst data. . . . . . . . . . . . . . . 129

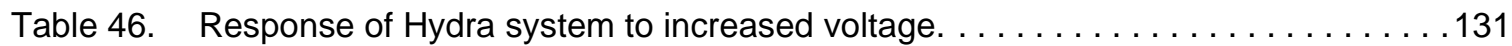

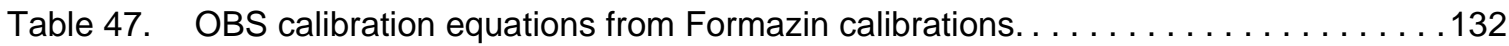




\section{INTRODUCTION}

\subsection{Southwest Washington Coastal Erosion Study}

The Southwest Washington Coastal Erosion Study (SWCES) is a five-year multidisciplinary investigation of the Columbia River littoral cell, a 165-km long coastal region between Tillamook Head, Oregon and Point Grenville, Washington. The study is cosponsored by the U. S. Geological Survey and the Washington State Department of Ecology. The study was initiated in 1996 in response to several erosion crises on a coast that had been prograding for most of the 20th century (Gelfenbaum et al., 1997; Kaminsky et al., 1997). The goals of the study are to improve scientific understanding of coastal morphodynamics and sedimentary processes, to determine natural and anthropogenic influences on the littoral system, and to provide information and predictions of coastal change on scales suitable for coastal management.

\subsection{Grays Harbor Wave Refraction Experiment}

The Grays Harbor Wave Refraction Experiment was designed to provide information that can be used to improve predictive numerical modeling of shoreline change. The objectives of the Grays Harbor Wave Refraction Experiment are:

1) Provide data to calibrate and verify numerical models of wave transformation (primarily refraction and shoaling) around an ebb-tidal delta in the high energy environment of the Pacific Northwest.

2) Provide measurements of bottom sediment size, waves, currents, and suspended-sediment concentrations for calculations of sediment transport.

The experiment was conducted from October to December, 1999 because analysis of historical data indicated that wave height and direction of wave approach is especially variable as North Pacific weather patterns shift from autumn to winter (Tillotson and Komar, 1997). A deployment at this time would provide a range of wave conditions with which to calibrate wave transformation models. Measurements were made using six instrumented tripods deployed near the entrance to Grays Harbor. Mounted on the tripods were sensors for measuring wave- and tide-induced pressure elevations, currents, and suspended sediments. These instruments included pressure transducers, single-point, three-axis acoustic doppler velocimeters (ADVs), upward-looking acoustic doppler profilers (ADPs), and optical backscatter sensors (OBS). The tripod locations and instrumentation are discussed in the next section.

In addition to the instrumented tripods, bottom sediment grab samples were taken at all tripod sites, and profiles of water conductivity, temperature, and depth (CTD) were made. The grab samples were obtained for calibration of the OBSs deployed on the tripods and to aid in interpretation of acoustic backscatter data from previously collected side-scan sonar and multibeam surveys. The CTD profiles were collected to aid in the interpretation of the velocity profiles.

This report describes data collected during the Grays Harbor Wave Refraction Experiment, and provides additional information needed to interpret the data. The accompanying CD-roms contain an HTML page with links to the data files associated with this experiment, the data files, text files explaining the data file formats, pressure sensor calibration files, and a PDF version of this report. 


\section{DATA COLLECTION METHODS}

\subsection{Experiment Overview}

Six tripods were deployed in October 1999 on and around the entrance to Grays Harbor, Washington (Figure 1). Tripod locations are designated according to their relative location along the coast (N)orth, (M)iddle, or (S)outh, and their relative depth - (D)eep or (S)hallow. Thus ND refers to the northernmost, deeper location, and MS refers to the middle, shallower location. Also shown on Figure 1 is the location of the Grays Harbor directional wave buoy \#03601, which is maintained by the Coastal Data Information Program (CDIP) and is moored in 42-m water depth offshore of the southernmost sites (SD and SS). Data collected by the CDIP buoy during the time of the experiment is plotted in Figure 2 and can be downloaded from the CDIP web site (http://cdip.ucsd.edu/). The locations of several of the U. S. Army Corps of Engineers (USACE) instruments deployed September 11 - November 17, 1999 are also shown in Figure 1. A description of the Corps of Engineers' data collection can be found on their web site (http://sandbar.wes.army.mil/public_html/ pmab2web/htdocs/proj_graysharbor.html). Data collected on the Grays Harbor ebb-tidal delta by USACE during April and May, 1999 are available on the web site as well as information about the autumn 1999 deployment.

The tripods were initially deployed October 1-2, 1999 (all dates and times in this report and within the data files are reported in Greenwich Mean Time, GMT). The fishing vessel Tricia Rae from Tokeland, Washington was used throughout the experiment. Deployment and sample locations were determined using a North Star differential GPS (model 941), which used the differential signal from U. S. Coast Guard beacons. These were checked against a Trimble differential GPS; positional accuracy was approximately $\pm 4 \mathrm{~m}$. Geographic positions are north latitude and west longitude, referenced to the North American Datum of 1983 (NAD83). Coordinates are also reported in Washington State Plane (South Zone) meters.

On November 2, 1999 the tripods at Sites NS, ND, and MS were retrieved. Data were downloaded from the instruments, batteries were replaced, and hardware was cleaned and refurbished. The Hydra system deployed at Site NS was damaged at an unknown time during the first deployment and was replaced. The tripods at Sites NS, ND, and MS were redeployed on November 5, 1999.

The tripod at Site SS was pulled up to check its condition on November 5, 1999 at 0325 GMT. It came off the bottom fairly easily and appeared to be in good condition. Within 3 minutes (by 0328), it was returned to the bottom at N 46 $53.498^{\prime} \mathrm{W} 124^{\circ} 11.190^{\prime}$.

On November 27, 1999, the tripods at Sites MD, SD, and SS were recovered. Data were downloaded and batteries were replaced. Instruments, cabling, and necessary hardware were cleaned and replaced. The tripods at Sites MD, SD, and SS were redeployed later that day.

On December 29, 1999, all six tripods were recovered and the data were downloaded. Navigational data indicated that the tripod at Site MD was recovered approximately $55 \mathrm{~m}$ from its deployment site but there is no other evidence that the tripod had moved. Otherwise, the recovery was unremarkable. Tables 1 and 2 show the date, time, and location of deployment and recovery for each tripod during the two deployments. Times of data collection are illustrated in Figure 3. 


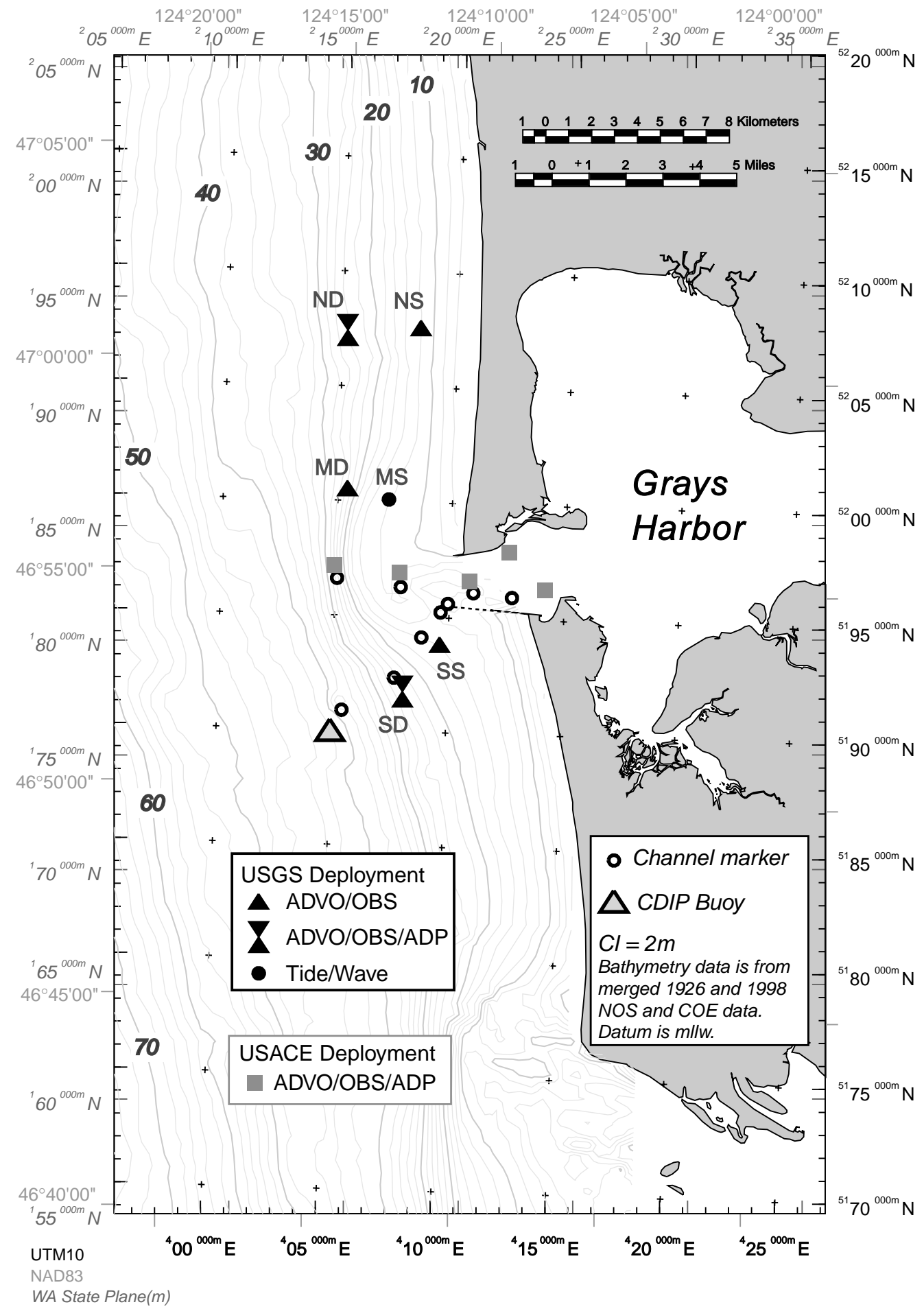

Figure 1. Chart of the study area near Grays Harbor, Washington showing sites where USGS tripods were deployed for the wave refraction experiment.Also shown are some of the locations of the USACE instruments and the location of the Grays Harbor directional wave buoy (Coastal Data Information Program Buoy \#03601). 
a) Significant Wave Height $H_{s}$

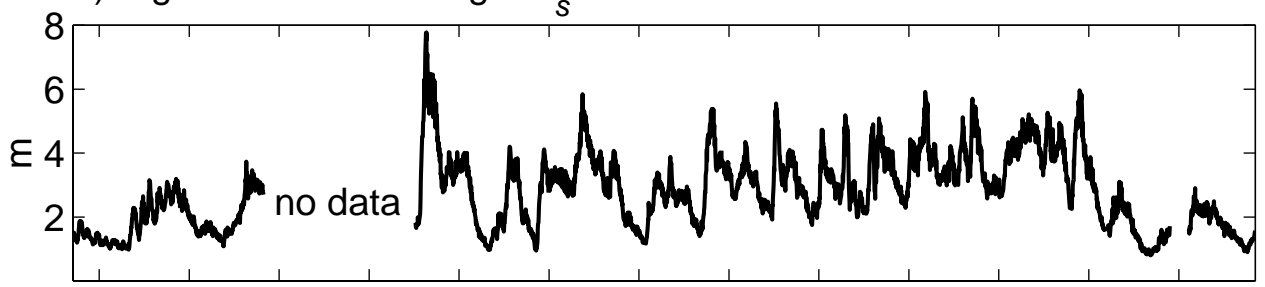

b) Peak Period $T_{p}$

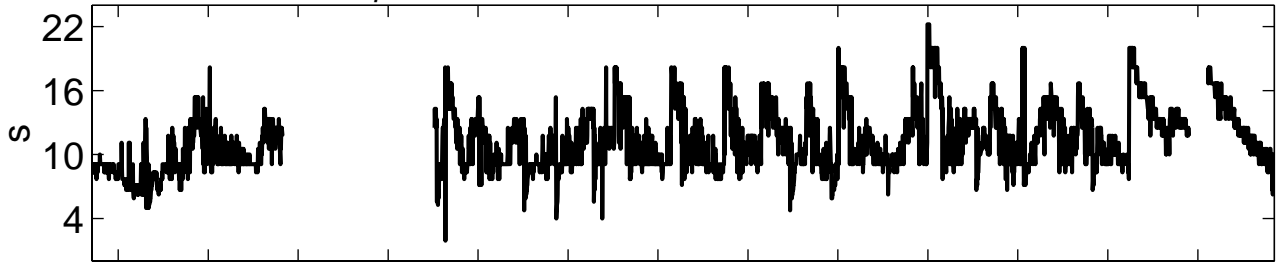

c) Dominant Direction

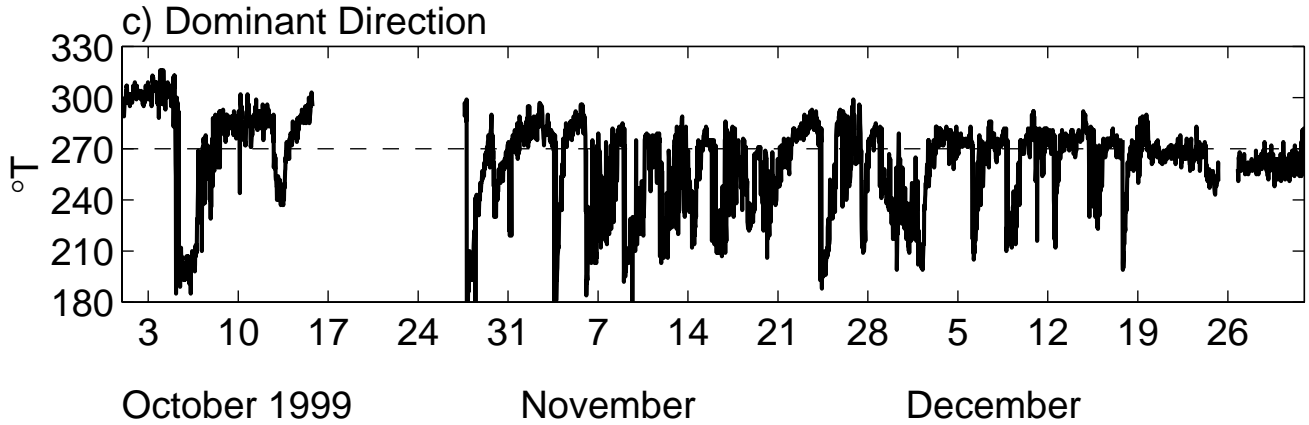

Figure 2. Time series of data collected by the Grays Harbor, WA CDIP buoy during the time of the Grays Harbor Wave Refraction Experiment. The buoy broke free and was lost on October 15 and replaced on October 27, 1999. There was telephone failure December 25-26, 1999.

Table 1. Summary of Deployment 1.Times reported in GMT.

\begin{tabular}{|c|c|c|c|c|c|c|c|c|c|}
\hline \multirow{2}{*}{ Site } & \multirow{2}{*}{$\begin{array}{l}\text { North } \\
\text { Latitude }\end{array}$} & \multirow{2}{*}{$\begin{array}{l}\text { West } \\
\text { Longitude }\end{array}$} & \multirow{2}{*}{$\begin{array}{l}\text { Approx. } \\
\text { Depth } \\
\text { (m) }\end{array}$} & \multicolumn{2}{|c|}{$\begin{array}{l}\text { Washington State } \\
\text { Plane, South Zone }\end{array}$} & \multicolumn{2}{|c|}{ Deployment } & \multicolumn{2}{|c|}{ Recovery } \\
\hline & & & & $\begin{array}{l}\text { Easting } \\
\text { (m) }\end{array}$ & $\begin{array}{l}\text { Northing } \\
\text { (m) }\end{array}$ & Date & Time & Date & Time \\
\hline ND & $47^{\circ} 00.768^{\prime}$ & $124^{\circ} 14.772^{\prime}$ & 23 & 215273.1 & 193438.7 & $10 / 01 / 99$ & 1937 & $11 / 02 / 99$ & 2332 \\
\hline NS & $47^{\circ} 00.841^{\prime}$ & $124^{\circ} 12.299^{\prime}$ & 11 & 218418.6 & 193425.5 & 10/01/99 & 1900 & $11 / 02 / 99$ & 2310 \\
\hline MD & $46^{\circ} 57.059^{\prime}$ & $124^{\circ} 14.676^{\prime}$ & 22 & 215073.6 & 186568.7 & 10/02/99 & 1953 & $11 / 27 / 99$ & 0130 \\
\hline MS & $46^{\circ} 56.853^{\prime}$ & $124^{\circ} 13.089^{\prime}$ & 11 & 217070.5 & 186092.1 & 10/01/99 & 2055 & $11 / 02 / 99$ & 2229 \\
\hline SD & $46^{\circ} 52.411^{\prime}$ & $124^{\circ} 12.363^{\prime}$ & 22 & 217596.5 & 177828.5 & $10 / 02 / 99$ & 2040 & $11 / 27 / 99$ & 0300 \\
\hline$S^{*}$ & $46^{\circ} 53.507^{\prime}$ & $124^{\circ} 11.171^{\prime}$ & 13 & 219201.6 & 179786.0 & $10 / 02 / 99$ & 2057 & $11 / 27 / 99$ & 0330 \\
\hline
\end{tabular}


Table 2. Summary of Deployment 2.Times reported in GMT.

\begin{tabular}{|c|c|c|c|c|c|c|c|c|c|}
\hline \multirow{2}{*}{ Site } & \multirow{2}{*}{$\begin{array}{l}\text { North } \\
\text { Latitude }\end{array}$} & \multirow{2}{*}{$\begin{array}{l}\text { West } \\
\text { Longitude }\end{array}$} & \multirow{2}{*}{$\begin{array}{l}\text { Approx. } \\
\text { Depth } \\
\text { (m) }\end{array}$} & \multicolumn{2}{|c|}{$\begin{array}{l}\text { Washington State } \\
\text { Plane, South Zone }\end{array}$} & \multicolumn{2}{|c|}{ Deployment } & \multicolumn{2}{|c|}{ Recovery } \\
\hline & & & & $\begin{array}{l}\text { Easting } \\
(\mathrm{m})\end{array}$ & $\begin{array}{l}\text { Northing } \\
\text { (m) }\end{array}$ & Date & Time & Date & Time \\
\hline ND & $47^{\circ} 00.765^{\prime}$ & $124^{\circ} 14.790^{\prime}$ & 25 & 215247.5 & 193434.4 & $11 / 05 / 99$ & 0210 & $12 / 29 / 99$ & 1757 \\
\hline NS & $47^{\circ} 00.849^{\prime}$ & $124^{\circ} 12.302^{\prime}$ & $12^{1}$ & 218406.7 & 193440.9 & $11 / 05 / 99$ & 0145 & $12 / 29 / 99$ & 1740 \\
\hline $\mathrm{MD}^{2}$ & $46^{\circ} 57.094^{\prime}$ & $124^{\circ} 14.687^{\prime}$ & 22 & 215064.0 & 186634.1 & $11 / 27 / 99$ & 2010 & 12/29/99 & 1840 \\
\hline MS & $46^{\circ} 56.856^{\prime}$ & $124^{\circ} 13.098^{\prime}$ & 11 & 217058.1 & 186098.2 & $11 / 05 / 99$ & 0250 & $12 / 29 / 99$ & 1700 \\
\hline SD & $46^{\circ} 52.418^{\prime}$ & $124^{\circ} 12.353^{\prime}$ & 22 & 217609.8 & 177840.9 & $11 / 27 / 99$ & 1925 & $12 / 29 / 99$ & 0724 \\
\hline SS & $46^{\circ} 53.505^{\prime}$ & $124^{\circ} 11.200^{\prime}$ & 13 & 219163.3 & 179784.1 & $11 / 27 / 99$ & 1855 & $12 / 29 / 99$ & 0706 \\
\hline
\end{tabular}

TField logs indicate deployment depth of $17 \mathrm{~m}$ (Table 14) but pressure records indicate depth of $12 \mathrm{~m}$ (Table 13).

2 Tripod was recovered at N 46 $57.119^{\prime} \mathrm{W} 124^{\circ}$ 14.663' (Easting = 215091.5; Northing =186679.1).

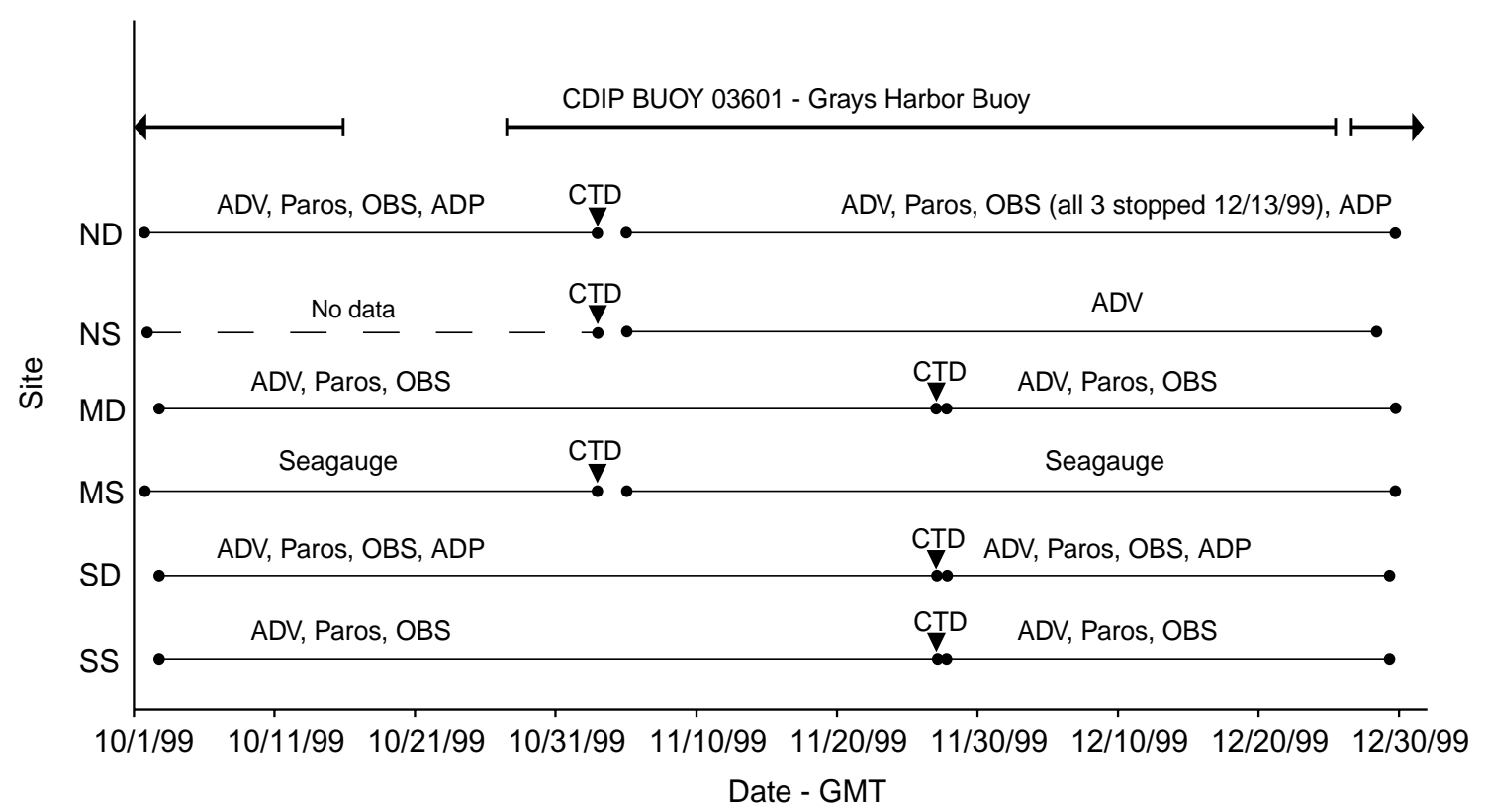

Figure 3. Timeline showing data collection period.

\subsection{Instruments and Tripods}

\subsubsection{SonTek Hydra System}

Five tripods (Sites ND, NS, MD, SD and SS) were instrumented with a SonTek Hydra system. Each Hydra system incorporated an ADVOcean acoustic doppler velocimeter (ADV), a Paroscientific digiquartz pressure sensor, and an optical backscatter sensor (OBS) manufactured by D \& A Instruments. Serial numbers and sampling parameters are listed in Table 3. The ADVOcean is a single-point current meter which measures three axes (east, north, and up) of current velocity in a small, undisturbed volume approximately $16 \mathrm{~cm}$ from the transmitter. Each ADVOcean also measures temperature, compass heading, pitch, and roll. All data were recorded on an internal data logger housed in a separate pressure housing and power was supplied from an external battery canister. For Deployment 2, Site NS, the damaged Hydra system from Deployment 1 was replaced. The new system did not include an OBS sensor and the external Paros pressure sensor 
was replaced with an internal strain gauge. The data logger and batteries were mounted in the same pressure housing.

The Hydra system sampled continuously for 34.13 minutes and recorded at $2 \mathrm{~Hz}$ (4096 samples) every 2 hours during Deployment 1 and every hour during Deployment 2 . The bursts were centered on the hour (i.e., they began at HH42:56).

Table 3. SonTek Hydra system serial numbers and sampling parameters.

\begin{tabular}{lllllllll}
\hline Site & Dep \# & $\begin{array}{l}\text { ADVOcean } \\
\text { and Data } \\
\text { Logger S/N }\end{array}$ & $\begin{array}{l}\text { Paros } \\
\text { S/N }\end{array}$ & $\begin{array}{l}\text { OBS } \\
\text { S/N }\end{array}$ & $\begin{array}{l}\text { Sampling } \\
\text { Rate (Hz) }\end{array}$ & $\begin{array}{l}\text { Burst } \\
\text { Interval } \\
\text { (s) }\end{array}$ & $\begin{array}{l}\text { Samples } \\
\text { Per Burst }\end{array}$ & $\begin{array}{l}\text { Burst } \\
\text { Length } \\
\text { (s) }\end{array}$ \\
\hline ND & 1 & B45 & 66890 & 795 & 2 & 7200 & 4096 & 2048 \\
& 2 & B45 & 66890 & 795 & 2 & 3600 & 4096 & 2048 \\
NS & 1 & B46 & 69128 & 928 & 2 & 7200 & 4096 & 2048 \\
& 2 & B100 & - & - & 2 & 3600 & 4096 & 2048 \\
MD & 1 & B51 & 69130 & 1242 & 2 & 7200 & 4096 & 2048 \\
& 2 & B51 & 69130 & 1242 & 2 & 3600 & 4096 & 2048 \\
SD & 1 & B52 & 69180 & 1243 & 2 & 7200 & 4096 & 2048 \\
& 2 & B52 & 69180 & 1243 & 2 & 3600 & 4096 & 2048 \\
SS & 1 & B59 & 69181 & 1244 & 2 & 7200 & 4096 & 2048 \\
& 2 & B59 & 69181 & 1244 & 2 & 3600 & 4096 & 2048 \\
\hline
\end{tabular}

\subsubsection{SonTek Acoustic Doppler Profiler (ADP)}

Two of the tripods (Sites ND and SD) were equipped with upward-looking SonTek acoustic doppler profilers (ADPs). ADPs measured profiles of three velocity components (east, north, and up) throughout the water column. Profiles were collected for 15 minutes every 30 minutes. Vertical cell size was $0.5 \mathrm{~m}$, starting $0.4 \mathrm{~m}$ from the transducer. Data were collected for 65 cells, up through the water column and past the level of the water surface. The instruments were set to measure as quickly as possible, and averaged profiles were recorded every half hour. The start time on the instrument was set so that the profiles were centered exactly on the hour and half-hour (i.e. HH52:30).

The ADPs were equipped with internally mounted Druck pressure sensors. Burst measurements of pressure (for wave and tide information) were collected with every other current profile, starting at the same time as the profile and continuing for 34.13 minutes at a rate of $2 \mathrm{~Hz}$ (4096 samples/ burst). Calibration information for the Druck pressure sensors used at Sites ND and SD are in files 958200.drk and 995410.drk, respectively, which are located on the accompanying CD, CD 03.

These pressure data are redundant and can be used as a cross-check with the pressure data from the Hydra's Paros pressure sensor.

The ADPs also measured and recorded water temperature, compass heading, pitch, and roll. Power was supplied from a separate battery canister. The same instruments and sampling scheme were used for both deployments at both sites. ADP sampling parameters are summarized in Table 4. 
Table 4. SonTek ADP serial numbers and sampling parameters.

\begin{tabular}{lll}
\hline & Site & Site \\
Parameter & ND & SD \\
\hline ADP serial number & C134 & C132 \\
Druck calibration file & 958200. drk & 995410. drk \\
Cell size $(\mathrm{m})$ & 0.5 & 0.5 \\
Blank distance $(\mathrm{m})$ & 0.4 & 0.4 \\
Number of cells & 65 & 65 \\
Averaging interval (s) & 900 & 900 \\
Profile interval (s) & 1800 & 1800 \\
Ping interval (s) & 0.0 & 0.0 \\
Wave sampling parameters: & & \\
Record waves after $X$ profiles & 2 & 2 \\
Wave burst sampling rate (Hz) & 2 & 2 \\
Number of samples per burst & 4096 & 4096 \\
Length of burst (s) & 2048 & 2048 \\
\hline
\end{tabular}

\subsubsection{Sea-Bird Seagauge Wave and Tide Recorder}

A Sea-Bird Seagauge Wave and Tide Recorder was deployed at Site MS and measured pressure and temperature. Data were recorded internally. Power was supplied by internal batteries. The same instrument and sampling scheme were used during both deployments (Table 5).

Tide data were collected every 20 minutes. Wave data were collected after every 6 tide measurements (every 2 hours) for 10 minutes at a rate of $2 \mathrm{~Hz}$ (1200 samples/burst). For Deployment 1 the start time was set so that wave bursts would be centered about the hour (i.e. HH55:00). For Deployment 2 the start time was set so that wave bursts would be centered about 20 minutes after the hour (i.e. HH15:01).

Table 5. Sea-Bird Seagauge serial number and sampling parameters for Site MS.

\begin{tabular}{ll}
\hline Parameter & Value \\
\hline Seagauge serial number & 131 \\
Tide measurement interval (min) & 20 \\
Measure waves after $N$ tide samples & 6 \\
Number of wave samples per burst & 1200 \\
Wave burst sample rate $(\mathrm{Hz})$ & 2 \\
Tide samples per day & 72 \\
Wave bursts per day & 12 \\
\hline
\end{tabular}

\subsubsection{Tripods}

All five tripods deployed at Sites ND, NS, MD, SD, and SS were identical (Figure 4). They were constructed of welded aluminum tubing with outside diameter of $7.62 \mathrm{~cm}$, and were approximately $2.5 \mathrm{~m}$ high and $3 \mathrm{~m}$ wide. The lower crossbars were placed high on the tripods $(106 \mathrm{~cm}$ above ground, approximately $30 \mathrm{~cm}$ above the ADV and OBS sampling volumes) to minimize flow disturbance and bottom scour. The circular feet had a diameter of $30.5 \mathrm{~cm}$, and were ballasted with removable cylindrical lead weights (diameter $=34.3 \mathrm{~cm}$; height $=11.4 \mathrm{~cm}$ ) weighing approximately $113 \mathrm{~kg}$ in air. 


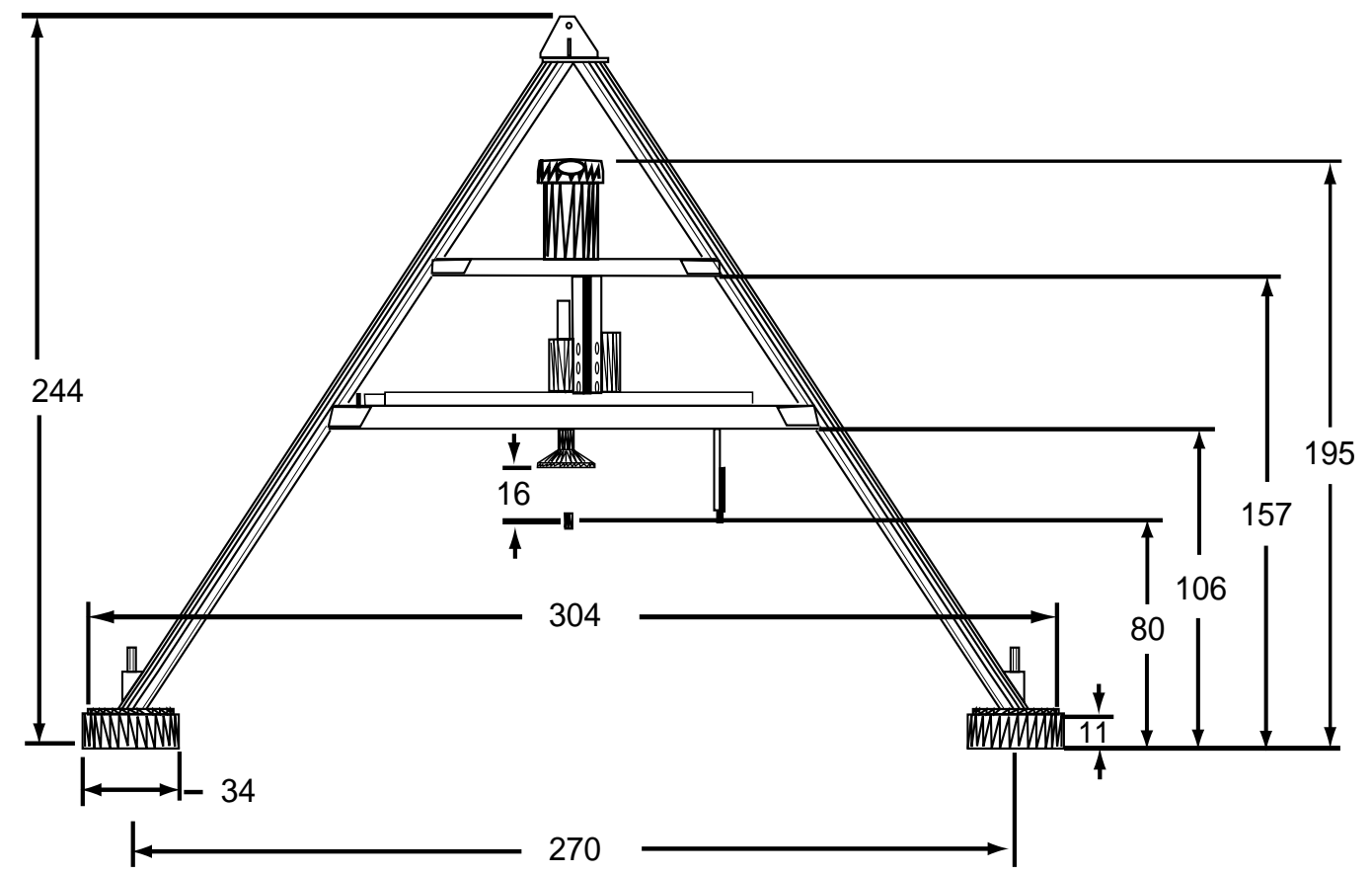

Figure 4. Schematic drawing of tripods deployed at Sites ND, NS, MD, SD, and SS.Dimensions indicated are in cm, and are nominal; see Table 6. Only Sites ND and SD had ADPs.

Tripods were lowered to the bottom using a crab block on 2.54-cm (1") polypropylene line, which was left tethered to a surface float (crab-pot buoy). Tripods were recovered with the same lifting line. Each tripod had a backup recovery system (which was never needed) consisting of a float, line canister, and acoustic release.

\subsubsection{Instrument Locations}

Instrument placement was similar on the five tripods (Figures 5 - 9), with the following exceptions. ADPs were mounted on the upper crossbars of tripods deployed at Sites ND and SD (Figures 5 and 6) and oriented such that the legs of the tripods did not interfere with the path of the ADP beams (Figure 10). The battery canister for the ADP was mounted on a lower crossbar(Figure 7). During Deployment 2, the tripod at Site NS had no OBS or Paros, and the data logger and batteries were contained in a single pressure case. The instruments were mounted in similar positions on all tripods. Heights of the sensors above the deck and horizontal separations were measured prior to each deployment (Table 6). The ADVs recorded distance to the sea bed with each burst, and these data indicate that the elevation of sensors relative to the sea bed varied during each deployment, and were always less than the distances listed in Table 6.

The tripod used to support the Sea-Bird Seagauge wave and tide recorder at Site MS differed from the others. It was constructed of rectangular tubing, the frame was about 1 meter shorter, and the crossbars were lower (Figure 11).

Field logs from the experiment are reproduced in Appendix A.1. These note the exact tripod locations, configurations, sampling schemes of the instruments, and instrumented tripod retrieval conditions for both deployments. 
Table 6. Relative positions of instruments on tripods.

\begin{tabular}{lllllll}
\hline Distance & Dep \# & ND & NS & MD & SD & SS \\
\hline \multirow{2}{*}{ Deck to ADVOcean transmitter (cm) } & 1 & 97.8 & 101.1 & 97.8 & 97.8 & 98.4 \\
& 2 & 97.8 & 99.1 & 97.8 & 97.8 & 98.4 \\
Deck to Paros pressure port (cm) & 1 & 116.4 & $117^{\star}$ & 116.8 & 116.8 & 117.5 \\
& 2 & 116.4 & N/A & 116.8 & 116.8 & 117.5 \\
Deck to OBS sensor (cm) & 1 & 79.1 & 81.3 & 78.1 & 78.1 & 80.6 \\
Horizontal between ADV and Paros (cm) & 2 & 79.1 & N/A & 78.1 & 78.1 & 80.6 \\
\multirow{2}{*}{ Deck to top of ADP $(\mathrm{cm})$} & 2 & 17.1 & $16^{*}$ & 16.5 & 15.2 & 15.2 \\
& 1 & 17.1 & N/A & 16.5 & 15.2 & 15.2 \\
& 2 & $195^{*}$ & N/A & N/A & 195.6 & N/A \\
\hline
\end{tabular}

* Approximate distance

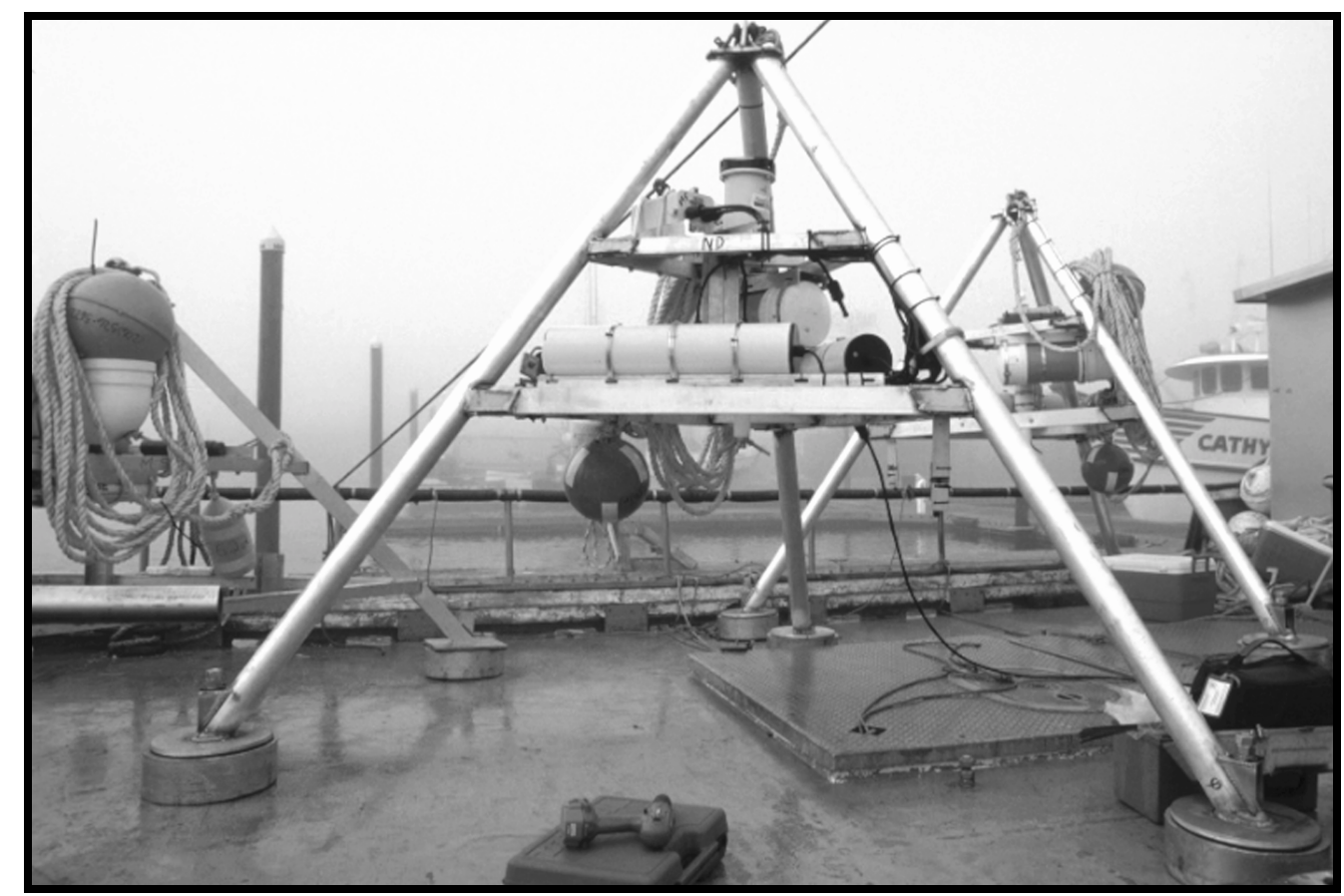

Figure 5. Photograph of tripods deployed at Sites MS, ND, and NS (left to right). 


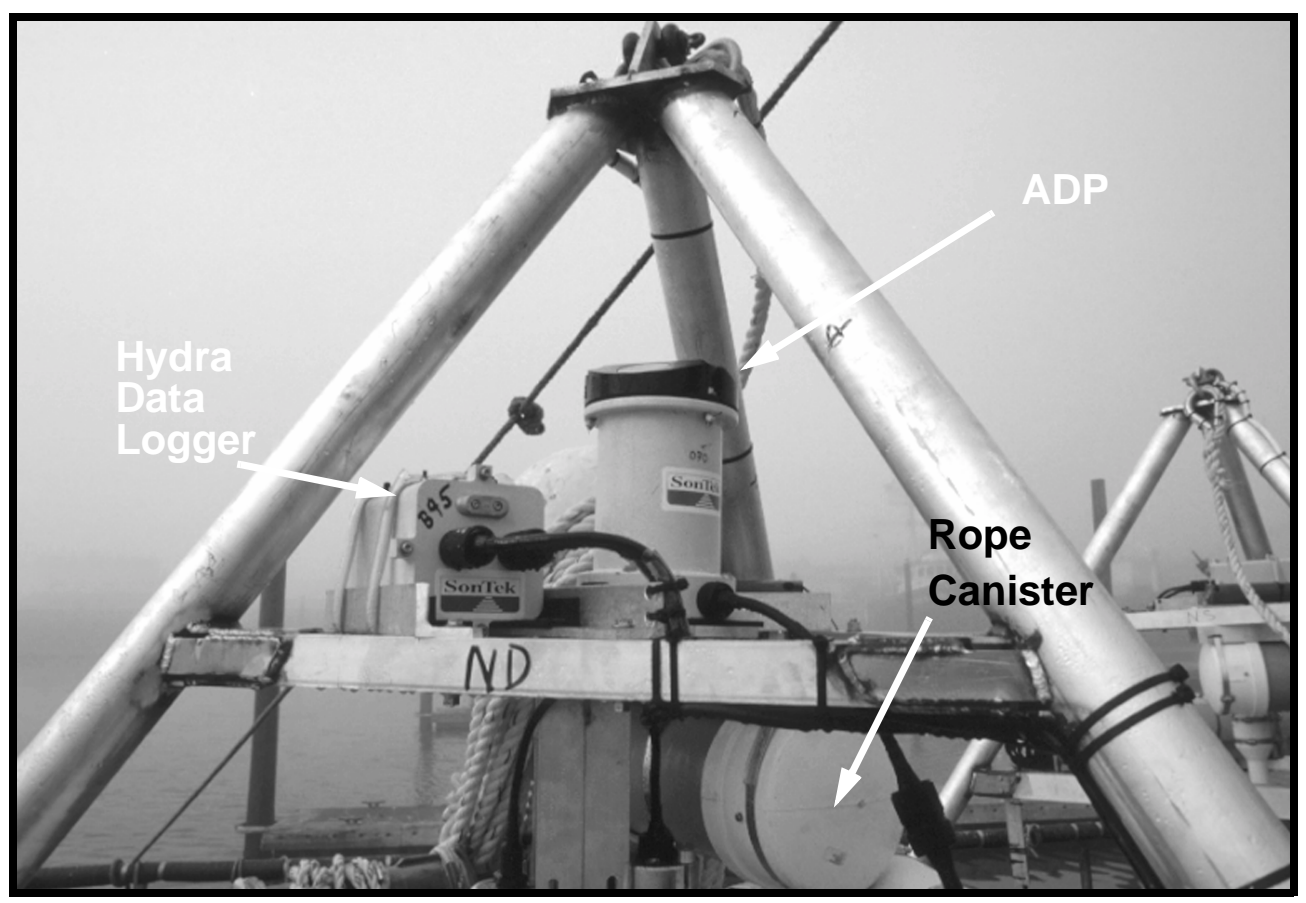

Figure 6. Photograph showing relative placement of Hydra data logger and ADP on tripod.

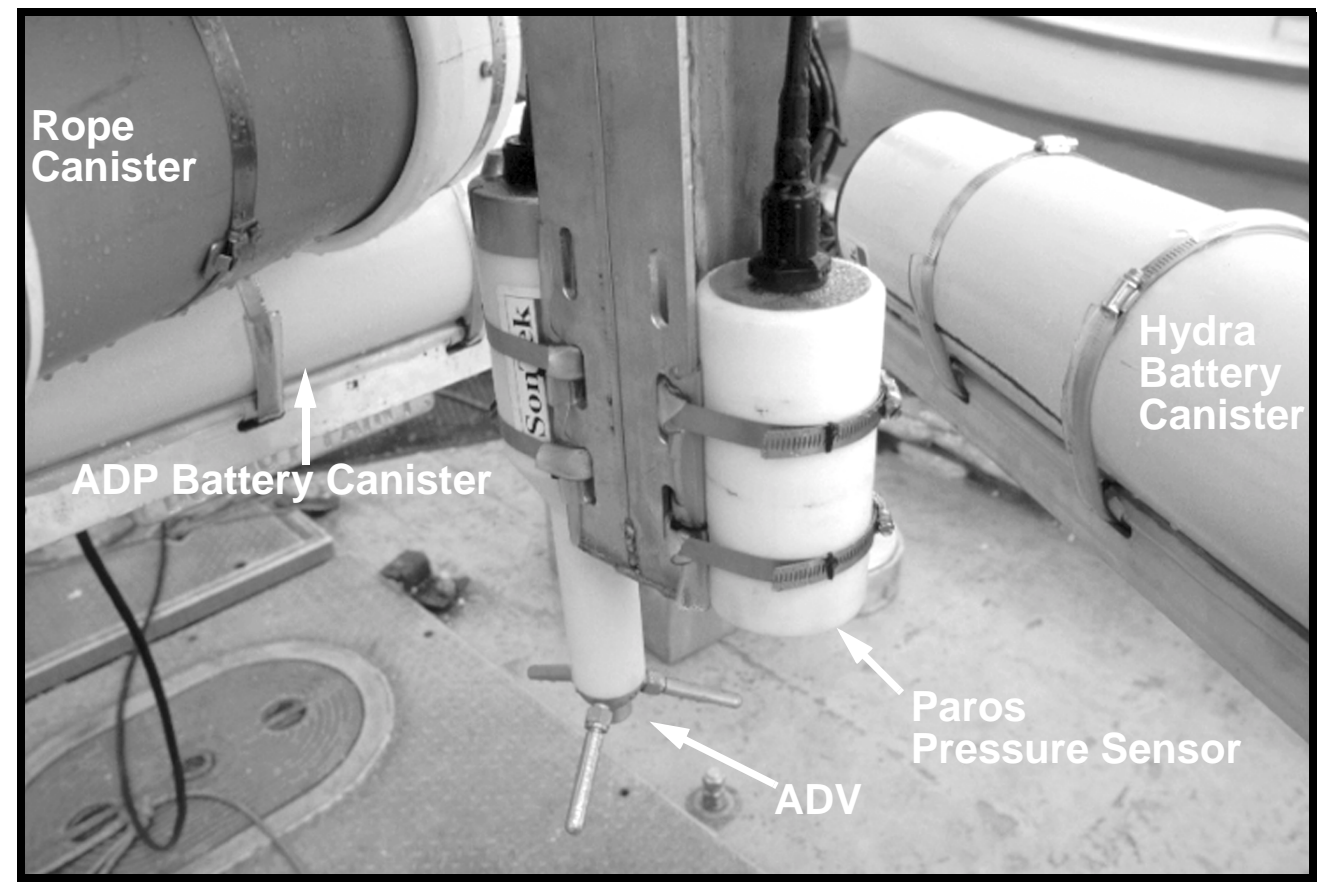

Figure 7. Photograph showing relative placement of Paros and ADVOcean on tripod. 


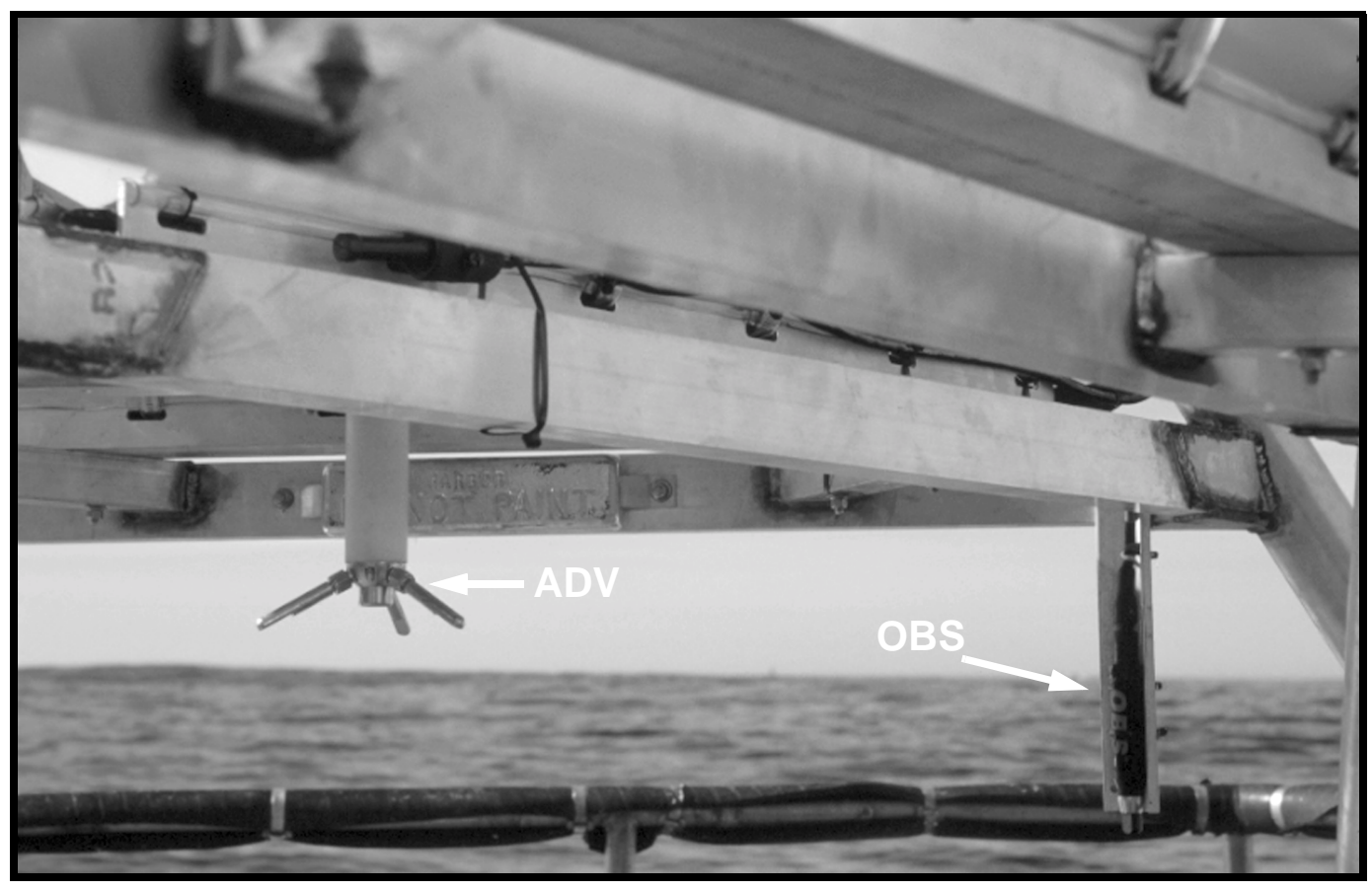

Figure 8. Photograph showing relative placement of ADV and OBS on tripod.

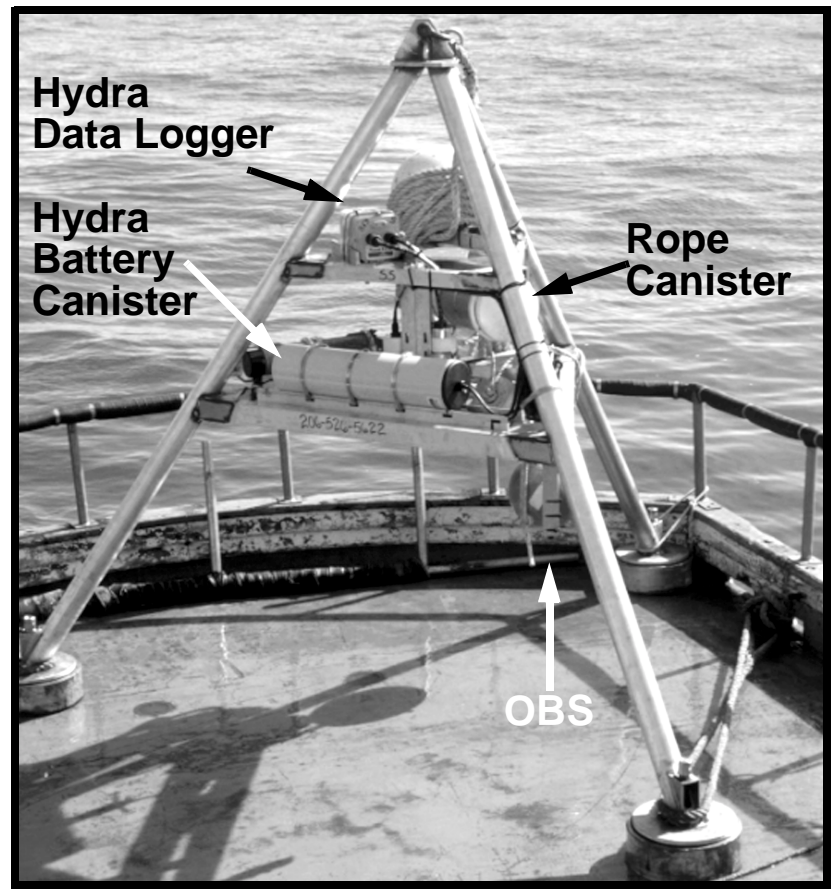

Figure 9. Photograph of tripod deployed at Site SS. 


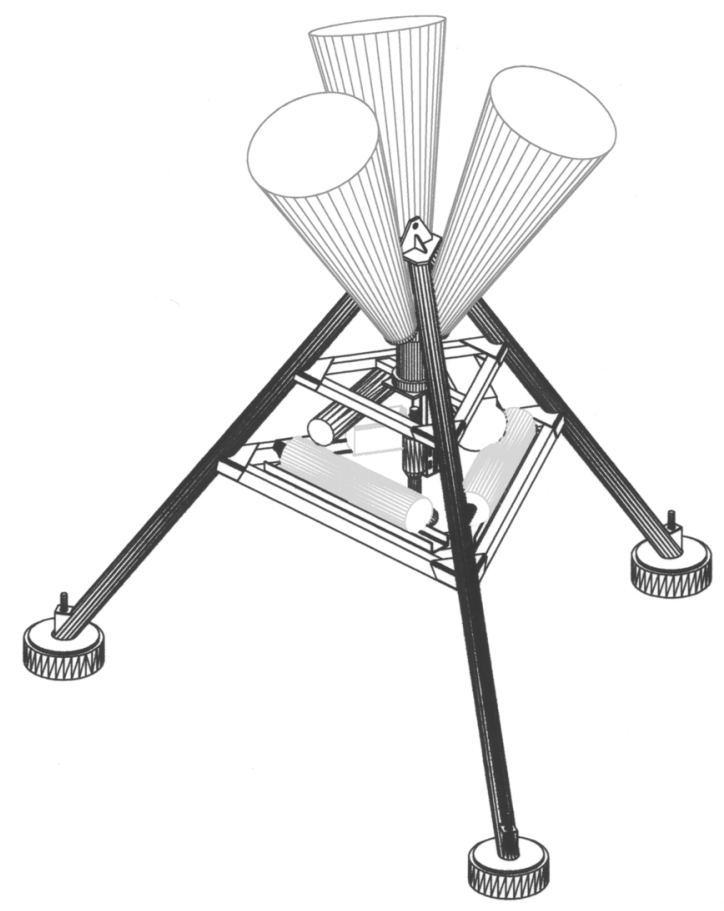

Figure 10. Schematic illustration of tripods deployed at Sites ND and SD, showing path of ADP beams.

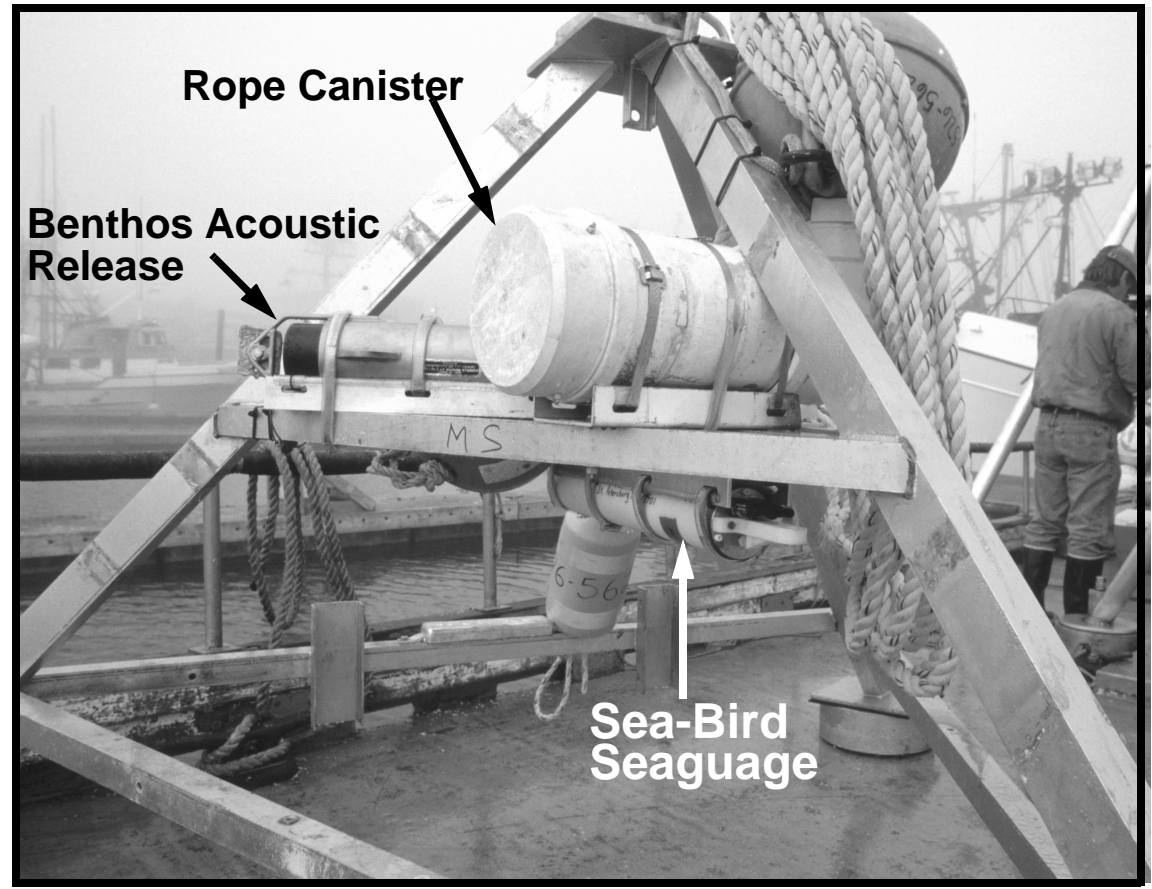

Figure 11. Photograph of tripod used to deploy the Sea-Bird Seagauge wave/tide recorder at Site MS. 


\subsubsection{Optical Backscatter Sensor Calibrations}

Optical backscatter sensors (OBS) were deployed on the tripods at all sites (except Site MS) to provide estimates of suspended sediment concentration. The OBS signal is an analog voltage ranging from 0 to $5 \mathrm{~V}$. The response of the OBS to mass concentration in a suspension of a standardized turbidity suspension such as Formazin is linear, so the output from each OBS can be calibrated in nepholometric turbidity units (NTU). NTUs cannot be directly converted to mass concentration of suspended sediment because the backscatter signal depends on the scattering area of suspended particles which, for a given mass concentration, can vary with sediment size. Therefore, a separate calibration must be done using sediment from the sampling location or in situ measurements.

Five OBS were deployed during the experiment and their data were logged by the SonTek Hydra systems. The Hydra system uses a 16-bit analog-digital converter, and records the 0 to $5-\mathrm{V}$ signal in counts ranging from 0 to 65535 .

Pre-experiment Formazin calibrations were performed to determine the response of the OBS, and an experiment was conducted with each Hydra system to find the conversion from volts to counts. The calibration procedures and results are described in Appendix D.

\subsection{Bottom Sediment Samples}

Grab samples of bottom sediments were obtained at the start of Deployment 1 using a Van Veen sampler. Samples were obtained from each of the sites (Table 7).

Table 7. Location of bottom sediment grab samples and comments from field notes.

\begin{tabular}{clllll}
\hline Site & $\begin{array}{l}\text { North } \\
\text { Latitude }\end{array}$ & $\begin{array}{l}\text { West } \\
\text { Longitude }\end{array}$ & $\begin{array}{l}\text { Washington State Plane } \\
\text { South Zone } \\
\text { Easting } \\
(\mathbf{m})\end{array}$ & $\begin{array}{l}\text { Northing } \\
(\mathbf{m})\end{array}$ & Comments \\
\hline ND & $47^{\circ} 00.750^{\prime}$ & $124^{\circ} 14.774^{\prime}$ & 215271.5 & 193405.4 & Few sand dollars, Gastropod \\
NS & $47^{\circ} 00.837^{\prime}$ & $124^{\circ} 12.314^{\prime}$ & 218393.0 & 193419.2 & Few sand dollars, Gastropod \\
MD & $46^{\circ} 57.041^{\prime}$ & $124^{\circ} 14.710^{\prime}$ & 215021.3 & 186537.8 & \\
MS & $46^{\circ} 56.841^{\prime}$ & $124^{\circ} 13.113^{\prime}$ & 217031.4 & 186071.7 & A lot of sand dollars \\
SD & $46^{\circ} 52.405^{\prime}$ & $124^{\circ} 12.371^{\prime}$ & 217583.3 & 177818.0 & Worm, Few sand dollars \\
SS & $46^{\circ} 53.533^{\prime}$ & $124^{\circ} 11.157^{\prime}$ & 219229.2 & 179833.0 & A lot of worm tubes, Small pebble $(\sim 3 \mathrm{~mm})$ \\
\hline
\end{tabular}

The grain size distribution of each sample was determined using standard USGS Coastal and Marine Geology procedures, modified from Folk (1968) and Carver (1971; chapter 4). Settling tubes (modified after Thiede et al., 1976, and similar to that described by Syvitski, 1991; chapters 1 and 4) were used for the sand fraction ( 4 phi to -1 phi, $0.063 \mathrm{~mm}$ to $2 \mathrm{~mm}$ ). The weight percentage of coarse $(<-1 \mathrm{phi},>2 \mathrm{~mm})$ and fine $(>4 \mathrm{phi},<0.063 \mathrm{~mm})$ fractions were determined, but no further analyses of these fractions were performed.

Statistical analyses of the results were obtained using a USGS-developed computer program. The program calculates graphical statistics, median, mean, skewness, and kurtosis, using methods presented by Folk and Ward, Inman (Carver,1971; chapter 6), and Trask (1930), and the moment measures (Carver, 1971; chapter 6). 


\subsection{CTD Profiles}

Profiles of conductivity, temperature, and depth (CTD) were measured with a Sea-Bird SBE 19 SEACAT at each site prior to retrieving the tripod after Deployment 1 (Table 8).

Table 8. Location and time of CTD casts.

\begin{tabular}{cllcccc}
\hline Site & \multicolumn{7}{c}{$\begin{array}{l}\text { Worth } \\
\text { Latitude }\end{array}$} & $\begin{array}{l}\text { West } \\
\text { Longitude }\end{array}$ & $\begin{array}{l}\text { South Zone } \\
\text { Easting } \\
(\mathbf{m})\end{array}$ & $\begin{array}{l}\text { Northing } \\
(\mathbf{m})\end{array}$ & Date & $\begin{array}{l}\text { Time } \\
\text { (GMT) }\end{array}$ \\
\hline ND & $47^{\circ} 00.750^{\prime}$ & $124^{\circ} 14.780^{\prime}$ & 215258.8 & 193406.0 & $11 / 03 / 99$ & 2327 \\
NS & $47^{\circ} 00.839^{\prime}$ & $124^{\circ} 12.300^{\prime}$ & 218405.8 & 193422.4 & $11 / 03 / 99$ & 2302 \\
MD & $46^{\circ} 57.057^{\prime}$ & $124^{\circ} 14.686^{\prime}$ & 215053.1 & 186566.0 & $11 / 27 / 99$ & 0138 \\
MS & $46^{\circ} 56.852^{\prime}$ & $124^{\circ} 13.171^{\prime}$ & 216955.1 & 186095.7 & $11 / 03 / 99$ & 2220 \\
SD & $46^{\circ} 52.411^{\prime}$ & $124^{\circ} 12.367^{\prime}$ & 217587.6 & 177829.0 & $11 / 27 / 99$ & 0308 \\
SS & $46^{\circ} 53.498^{\prime}$ & $124^{\circ} 11.190^{\prime}$ & 219175.4 & 179770.6 & $11 / 27 / 99$ & 0342 \\
\hline
\end{tabular}

The CTD sensor set-up was as described in the SBE 19 SEACAT manual, except that an external Paros pressure sensor was mounted at a level approximately in the middle of the conductivity tube, approximately $8 \mathrm{~cm}$ higher than the thermistor. There was no pump on the conductivity sensor. 


\section{DATA COLLECTED}

\subsection{Bottom Sediment Samples}

The results of grain-size analyses (weight percent in 1/4-phi intervals) are listed Table 9 and graphed in Figure 12. The samples at all sites except Site ND were very well sorted fine sands (Folk, 1974), with means of $2.73-2.40$ phi $(0.15-0.19 \mathrm{~mm}$ ) and sortings of $0.23-0.33$ phi (Folk and Ward classifications; Carver, 1971; Chapter 6). Sediment from Site ND was a moderately sorted fine sand with a mean size of $2.17 \mathrm{phi}(0.22 \mathrm{~mm})$, and sorting of $0.72 \mathrm{phi}$. Each sample contained little to no coarse fraction $(<0.67 \%)$ and little fine fraction $(<4 \%)$. Statistical descriptions of each sediment sample are reported in Table 10. Settling velocity has been calculated using Gibbs (1971) equation for settling velocity at $10^{\circ} \mathrm{C}, 30 \mathrm{psu}$, and $18 \mathrm{dbar}$.

Table 9. Results of grain size analysis reported as weight percent at 1/4 phi intervals (with associated settling velocity).

\begin{tabular}{|c|c|c|c|c|c|c|c|}
\hline phi class & $\begin{array}{l}\text { Settling } \\
\text { Velocity } \\
(\mathrm{cm} / \mathrm{s})\end{array}$ & ND & NS & MD & MS & SD & SS \\
\hline-1.00 & 26.5 & 0.12 & 0.00 & 0.00 & 0.00 & 0.67 & 0.41 \\
\hline-0.75 & 23.1 & 0.00 & 0.00 & 0.00 & 0.00 & 0.00 & 0.00 \\
\hline-0.50 & 19.9 & 0.00 & 0.00 & 0.00 & 0.00 & 0.00 & 0.00 \\
\hline-0.25 & 17.1 & 0.00 & 0.00 & 0.00 & 0.00 & 0.00 & 0.00 \\
\hline 0.00 & 14.5 & 0.00 & 0.00 & 0.00 & 0.00 & 0.00 & 0.00 \\
\hline 0.25 & 12.2 & 0.00 & 0.00 & 0.00 & 0.00 & 0.00 & 0.00 \\
\hline 0.50 & 10.2 & 0.16 & 0.00 & 0.00 & 0.00 & 0.00 & 0.50 \\
\hline 0.75 & 8.5 & 0.48 & 0.00 & 0.00 & 0.00 & 0.00 & 0.33 \\
\hline 1.00 & 6.9 & 1.60 & 0.33 & 0.00 & 0.00 & 0.00 & 0.17 \\
\hline 1.25 & 5.6 & 9.34 & 1.48 & 0.00 & 0.33 & 0.00 & 0.82 \\
\hline 1.50 & 4.5 & 8.21 & 1.33 & 0.00 & 1.16 & 0.00 & 0.66 \\
\hline 1.75 & 3.5 & 9.49 & 2.47 & 0.00 & 2.49 & 0.00 & 1.32 \\
\hline 2.00 & 2.7 & 13.04 & 3.13 & 0.16 & 5.64 & 0.17 & 3.14 \\
\hline 2.25 & 2.1 & 10.62 & 2.97 & 2.10 & 12.27 & 0.00 & 9.08 \\
\hline 2.50 & 1.6 & 6.44 & 6.92 & 9.06 & 30.01 & 11.02 & 21.63 \\
\hline 2.75 & 1.2 & 14.80 & 32.98 & 43.67 & 42.11 & 41.67 & 49.70 \\
\hline 3.00 & 0.88 & 10.95 & 43.03 & 32.51 & 4.81 & 35.35 & 11.06 \\
\hline 3.25 & 0.64 & 8.69 & 3.96 & 5.34 & 0.34 & 6.16 & 0.50 \\
\hline 3.50 & 0.47 & 2.09 & 0.16 & 2.26 & 0.33 & 1.62 & 0.17 \\
\hline 3.75 & 0.34 & 0.48 & 0.00 & 1.14 & 0.00 & 0.81 & 0.00 \\
\hline 4.00 & 0.24 & 0.16 & 0.17 & 0.49 & 0.00 & 0.49 & 0.00 \\
\hline 4.25 & 0.17 & 3.31 & 1.08 & 3.27 & 0.52 & 2.04 & 0.51 \\
\hline
\end{tabular}




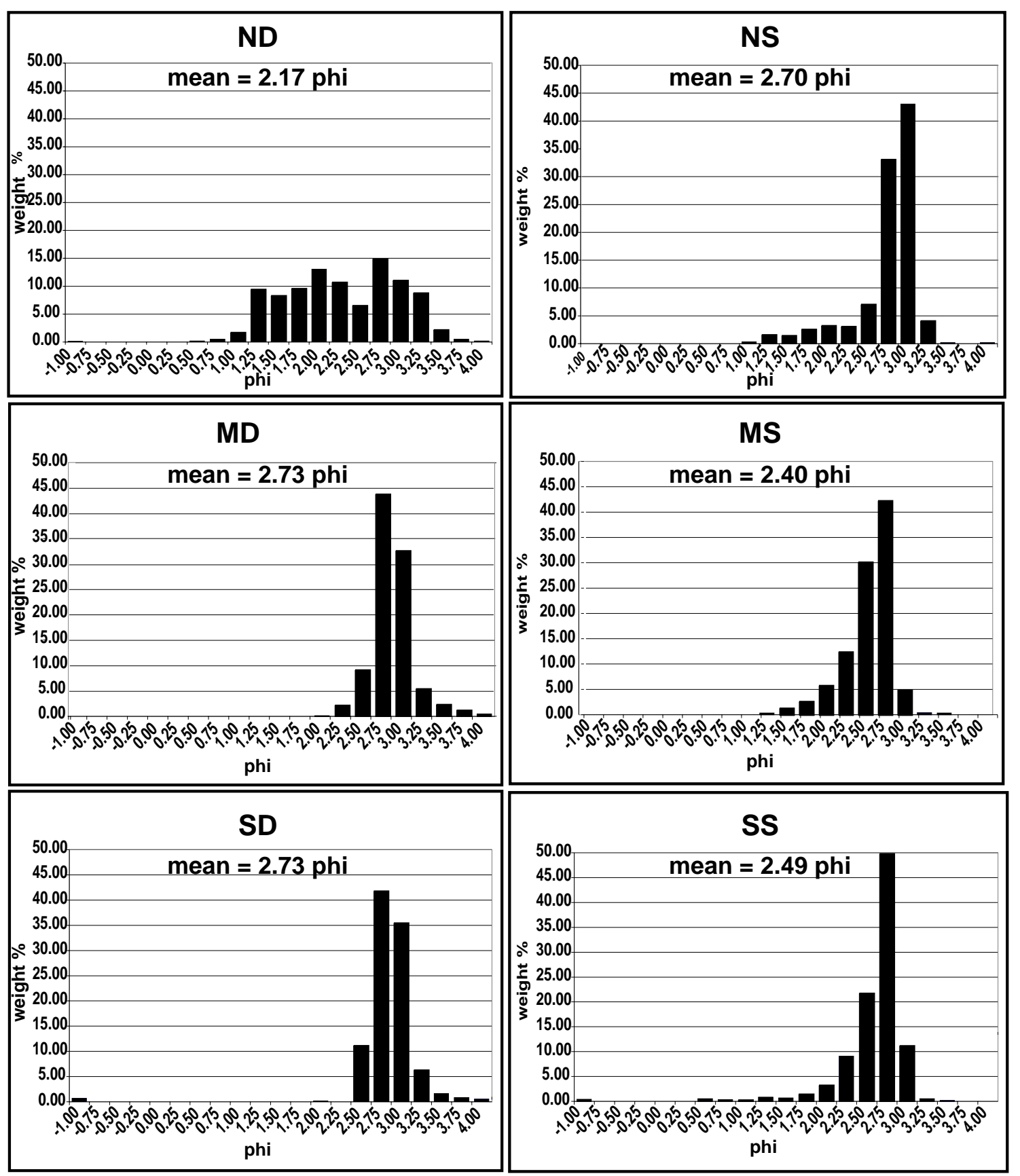

Figure 12. Grain size distribution histograms for the six sites. 
Table 10. Results of grain-size statistical analysis (phi, unless otherwise noted).

\begin{tabular}{lllllll}
\hline Site & ND & NS & MD & MS & SD & SS \\
\hline \% Gravel & 0.12 & 0.00 & 0.00 & 0.00 & 0.67 & 0.41 \\
\% Sand & 96.57 & 98.92 & 96.73 & 99.48 & 97.29 & 99.07 \\
\% Silt & 3.31 & 1.08 & 3.27 & 0.52 & 2.04 & 0.51 \\
\% Clay & 0.00 & 0.00 & 0.00 & 0.00 & 0.00 & 0.00 \\
\% Mud & 3.31 & 1.08 & 3.27 & 0.52 & 2.04 & 0.51 \\
1st moment & 2.22 & 2.65 & 2.78 & 2.43 & 2.74 & 2.47 \\
Variance & 0.60 & 0.18 & 0.13 & 0.11 & 0.26 & 0.24 \\
Std. deviation & 0.77 & 0.43 & 0.36 & 0.33 & 0.51 & 0.49 \\
3rd moment & 0.05 & -1.24 & 1.89 & -0.26 & -5.69 & -4.76 \\
4th moment & 3.77 & 7.41 & 8.20 & 7.47 & 61.86 & 44.26 \\
Folk and Ward: Median & 2.17 & 2.74 & 2.72 & 2.49 & 2.75 & 2.52 \\
Folk and Ward: Mean & 2.17 & 2.70 & 2.73 & 2.40 & 2.73 & 2.49 \\
Folk and Ward: Sorting & 0.72 & 0.33 & 0.25 & 0.24 & 0.23 & 0.28 \\
Folk and Ward: Skewness & 0.04 & -0.38 & 0.26 & -0.57 & -0.01 & -0.20 \\
Folk and Ward: Kurtosis & 0.77 & 1.97 & 3.92 & 1.16 & 2.57 & 1.72 \\
Inman: Median & 2.17 & 2.74 & 2.72 & 2.49 & 2.75 & 2.52 \\
Inman: Mean & 2.17 & 2.69 & 2.74 & 2.35 & 2.73 & 2.48 \\
Inman: Sorting & 0.79 & 0.25 & 0.18 & 0.19 & 0.18 & 0.23 \\
Inman: Skewness 1 & 0.01 & -0.20 & 0.11 & -0.76 & -0.13 & -0.15 \\
Inman: Skewness 2 & 0.08 & -1.49 & 1.24 & -0.98 & 0.26 & -0.59 \\
Inman: Kurtosis & 0.33 & 1.63 & 2.04 & 1.61 & 1.53 & 1.30 \\
Trask: Median (mm) & 0.22 & 0.15 & 0.15 & 0.18 & 0.15 & 0.17 \\
Trask: Mean (mm) & 0.23 & 0.15 & 0.15 & 0.18 & 0.15 & 0.18 \\
Trask: Sorting (mm) & 1.48 & 1.10 & 1.04 & 1.13 & 1.05 & 1.09 \\
Trask: Skewness & 0.95 & 0.99 & 1.01 & 1.04 & 1.06 & 1.01 \\
Trask: Kurtosis & 0.28 & 0.15 & 0.09 & 0.25 & 0.13 & 0.18 \\
\hline & & & & & &
\end{tabular}

Side-scan sonar and multibeam backscatter data (Twichell et al., 2000; R. Flood, personal communication, 1999) suggest that gravel patches with abrupt boundaries exist in several locations within the study area. The sediment sample at Site ND was taken close to a gravel patch, which may account for the coarser, more poorly sorted sediment found at that site.

\subsection{CTD Casts}

Depth, salinity, and density were calculated from pressure, conductivity, and temperature, using software provided by Sea-Bird Instruments, Inc. (Sea-Bird Electronics, Inc., 2000a). Converted data were subsampled to include only readings from the upward half of the cast, and only those data acquired when pressure indicated upward movement of the instrument. In addition, only data with conductivity greater than 3.0 Siemen's $/ \mathrm{m}(30 \mathrm{mmho} / \mathrm{cm})$ were included, which eliminated some readings very close to the sea surface that may have been affected by bubbles. The resulting data were interpolated using a nearest-neighbor routine to provide profiles with data at $0.2-\mathrm{m}$ depth intervals (Figures 13 and 14).

Temperature measured during the CTD profiles generally ranged between 10.5 and $11^{\circ} \mathrm{C}$ and salinities ranged from 26-31 psu near the surface to approximately 32 psu at depth. The profiles indicate moderate and usually gradual temperature and salinity stratification in the upper $5-10 \mathrm{~m}$ of the water column. Beneath about $10 \mathrm{~m}$, water is relatively well mixed, except for a thin layer of warm water with salinity of about 31.4 psu that was observed near the bottom at Sites NS and MS. 
A warm, fresh surface layer 5-m thick with a sharp pycnocline was observed at Site MD, and a less distinct surface layer (similar temperature and thickness, but more saline) was measured at Site ND.
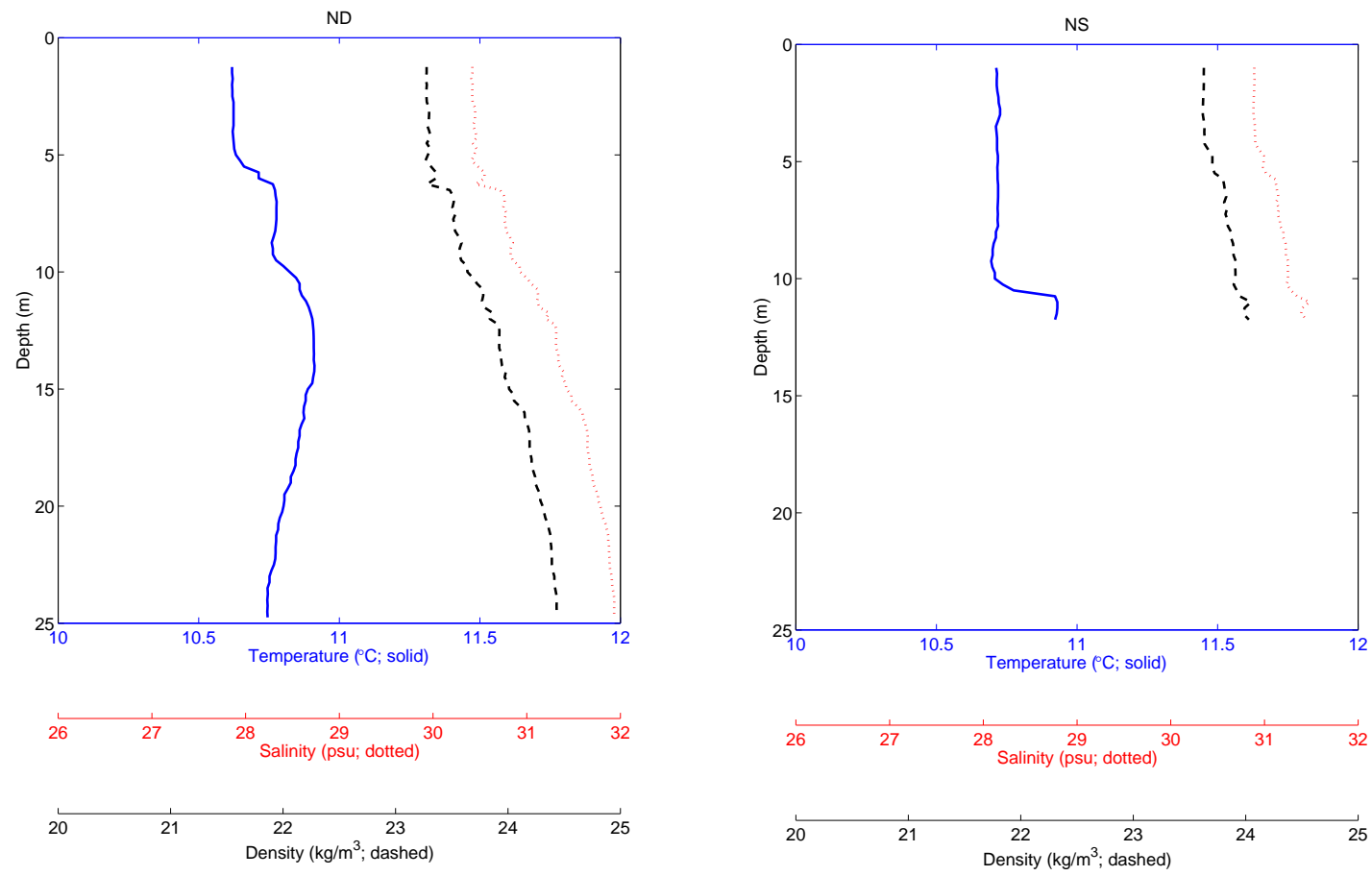

Figure 13. Profiles of salinity, temperature, and density measured at Sites ND and NS on November 3, 1999. 

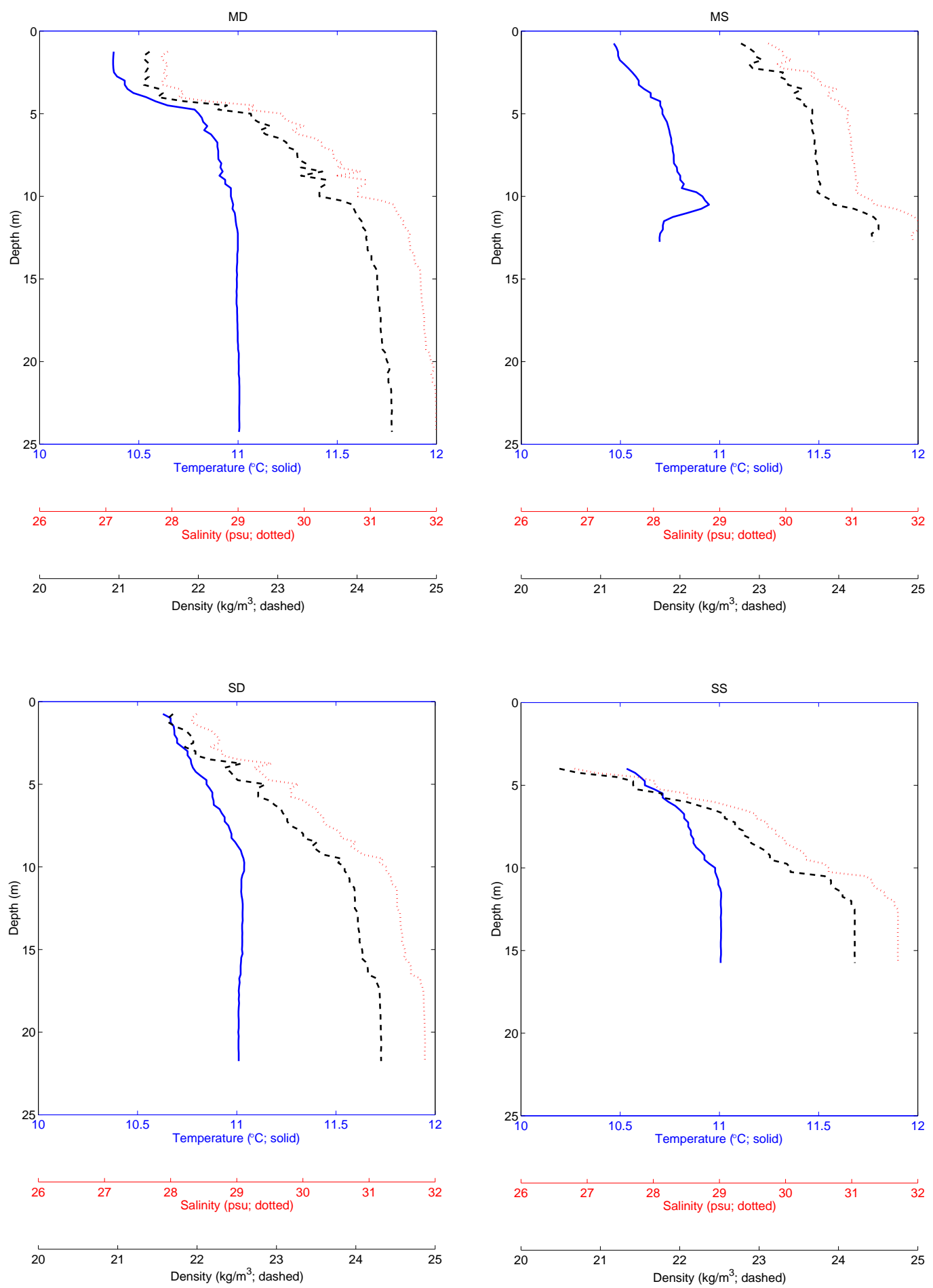

Figure 14. Profiles of salinity, temperature, and density measured at Site MS on November 3 , 1999, and Sites MD, SD, and SS on November 27, 1999. 


\subsection{Instruments}

Periods of valid data collection, i.e. times when the tripod was on the bottom during the entire burst, are shown in Table 11. The start and end times of valid data collection were determined by calculating the mean and standard deviation of the entire pressure record and finding the first and last points in the record to fall within one and a half standard deviations of the mean. The exception to this was the beginning of the ADP data record collected at Site SD during Deployment 1 , when the pressure sensor was not working correctly. For these data, visual inspection of the heading and temperature records was used to determine the first valid data record.

Table 11. Date, time, and burst number of first and last valid data record for each system deployed.

\begin{tabular}{|c|c|c|c|c|c|}
\hline \multirow[b]{2}{*}{ Site } & \multirow[b]{2}{*}{ Instrument } & \multicolumn{2}{|c|}{ Deployment 1} & \multicolumn{2}{|c|}{ Deployment 2} \\
\hline & & $\begin{array}{l}\text { First Good } \\
\text { Record - } \\
\text { Start Time }\end{array}$ & $\begin{array}{l}\text { Last Good } \\
\text { Record - } \\
\text { Start Time }\end{array}$ & $\begin{array}{l}\text { First Good } \\
\text { Record - } \\
\text { Start Time }\end{array}$ & $\begin{array}{l}\text { Last Good } \\
\text { Record - } \\
\text { Start Time }\end{array}$ \\
\hline \multirow{3}{*}{ ND } & \multirow{3}{*}{ ADV } & $10 / 02 / 99$ & $11 / 02 / 99$ & $11 / 05 / 99$ & $12 / 11 / 99$ \\
\hline & & $0042: 57$ & $2242: 57$ & 0242:57 & $2042: 57$ \\
\hline & & Burst \# 5 & Burst \# 388 & Burst \# 8 & Burst \# 891 \\
\hline \multirow{3}{*}{ ND } & \multirow{3}{*}{ ADP } & $10 / 01 / 99$ & $11 / 02 / 99$ & $11 / 05 / 99$ & $12 / 29 / 99$ \\
\hline & & $1952: 30$ & $2252: 30$ & 0222:30 & $1722: 30$ \\
\hline & & Burst \# 5 & Burst \# 1547 & Burst \# 16 & Burst \# 2638 \\
\hline \multirow{3}{*}{ NS } & \multirow{3}{*}{ ADV } & & & $11 / 05 / 99$ & 12/28/99 \\
\hline & & * & * & 0247:57 & 0842:57 \\
\hline & & & & Burst \# 1 & Burst \# 1279 \\
\hline \multirow{3}{*}{ MD } & \multirow{3}{*}{ ADV } & $10 / 02 / 99$ & $11 / 27 / 99$ & $11 / 27 / 99$ & $12 / 29 / 99$ \\
\hline & & $2042: 58$ & $0042: 57$ & $2042: 58$ & $1742: 58$ \\
\hline & & Burst \# 2 & Burst \# 664 & Burst \# 1 & Burst \# 766 \\
\hline \multirow{3}{*}{ MS } & \multirow{3}{*}{ Seagauge } & $10 / 01 / 99$ & $11 / 02 / 99$ & $11 / 05 / 99$ & 12/29/99 \\
\hline & & $2055: 00$ & $2155: 00$ & 0255:01 & $1635: 01$ \\
\hline & & Burst \# 30 & Burst \# 2337 & Burst \# 56 & Burst \# 3985 \\
\hline \multirow{3}{*}{ SD } & \multirow{3}{*}{ ADV } & $10 / 02 / 99$ & $11 / 27 / 99$ & $11 / 27 / 99$ & $12 / 29 / 99$ \\
\hline & & $2042: 58$ & $0242: 58$ & $2042: 58$ & $0642: 58$ \\
\hline & & Burst \# 2 & Burst \# 665 & Burst \# 1 & Burst \# 755 \\
\hline \multirow{3}{*}{ SD } & \multirow{3}{*}{ ADP } & $10 / 02 / 99$ & $11 / 27 / 99$ & $11 / 27 / 99$ & $12 / 29 / 99$ \\
\hline & & $2052: 30$ & 0252:30 & $2052: 30$ & 0652:30 \\
\hline & & Burst \# 5 & Burst \# 2657 & Burst \# 1 & Burst \# 1509 \\
\hline \multirow{3}{*}{ SS } & \multirow{3}{*}{ ADV } & $10 / 02 / 99$ & 11/27/99 & 11/27/99 & 12/29/99 \\
\hline & & $2242: 58$ & $0242: 58$ & $2042: 58$ & 0542:58 \\
\hline & & Burst \# 3 & Burst \# 665 & Burst \# 1 & Burst \# 754 \\
\hline
\end{tabular}

* Instrument damaged - no data retrieved

The mean, standard deviation, minimum and maximum values were found for the following data records: pressure, temperature, east, north, and up velocity components, speed, distance to the bottom from the center of the ADV sampling volume, and turbidity. Several adjustments to the data were made before calculating these statistics.

1) Pressure was adjusted to remove an approximate value for atmospheric pressure by subtracting 14.75 psia from the Seagauge pressure record, $0.19 \mathrm{dbar}$ from the ADV pressure record from Site NS, and $10.209 \mathrm{dbar}$ from the remaining ADV and ADP pressure records.

2) East and north velocity components from the ADV and ADP data were rotated to True North by adding a magnetic declination of $19^{\circ}$. These rotated values were used in calculating current speed and direction. 
3) Turbidity was calculated from the suspended sediment data collected by the OBS. The information used to convert counts to NTUs are found in Appendix D. Negative turbidity values, reported as the minimum for several deployments, are a result of not forcing the least squares linear regression of calibration data through zero.

The statistics were calculated using data that met the following quality assurance criteria:

1) Instrument was on the bottom for the entire burst. This was determined with methods described at the beginning of Section 3.3 and the results are listed in Table 11.

2) Significant wave height $\left(H_{\mathrm{s}}\right)$ was less than $10 \mathrm{~m}$ (Table 12).

3) Mean period $\left(T_{\mathrm{m}}\right)$ was greater than $2 \mathrm{~s}$ and less than $24 \mathrm{~s}$ (Table 12).

4) Distance to the bottom was positive. (The Hydra records "- 0.01 " when the bottom can not be detected.)

In addition,

1) Visual inspection of data plots revealed one outlying data point in the ADV pressure record from Site SD during Deployment 2 (Table 12).

2) Visual inspection of the beginning of the ADP pressure record collected at Site SD during Deployment 1 suggested that the pressure sensor was not working correctly. It was determined that the first valid pressure record was burst number 284. Therefore, pressure and wave data $\left(H_{s}\right.$ and $\left.T_{m}\right)$ collected before that time were discarded (Table 12).

These statistics and the number of data points used to calculate the statistics are reported in Table 13. Statistics are reported for each individual deployment as well as for the combined data record.

Table 12. Flagged bad data points. This does not include the points flagged as out of the water (Table 11). It is noted which data records (pressure $(p s)$, significant wave height $\left(H_{s}\right)$, mean period $\left.\left(T_{m}\right)\right)$ the point affected.

\begin{tabular}{lllllll}
\hline Site & Dep \# & System & Burst \# & Date & Time (center of burst) & $\begin{array}{l}\text { Data Type } \\
\text { Effected }\end{array}$ \\
\hline SD & 2 & ADV & 469 & $12 / 17 / 99$ & $0900: 02$ & $p s$ \\
SD & 1 & ADP & $5-283$ & $10 / 02 / 99$ through 10/08/99 & $2109: 34$ through 1609:34 & $p s, H_{s}, T_{m}$ \\
SD & 1 & ADP & 285 & $10 / 08 / 99$ & $1709: 34$ & $T_{m}$ \\
SD & 1 & ADP & 291 & $10 / 08 / 99$ & $2009: 34$ & $H_{s, T m}$ \\
SD & 1 & ADP & 339 & $10 / 9 / 99$ & $2009: 34$ & $T_{m}$ \\
SD & 1 & ADP & 855 & $10 / 20 / 99$ & $1409: 34$ & $T_{m}$ \\
SD & 1 & ADP & 1531 & $11 / 03 / 99$ & $1609: 34$ & $T_{m}$ \\
SD & 1 & ADP & 1565 & $11 / 04 / 99$ & $0909: 34$ & $T_{m}$ \\
SD & 1 & ADP & 2657 & $11 / 27 / 99$ & $0309: 34$ & $H_{s, T m}$ \\
SD & 2 & ADP & 575 & $12 / 09 / 99$ & $2009: 34$ & $H_{s, T m}$ \\
SD & 2 & ADP & 1149 & $12 / 21 / 99$ & $1909: 34$ & $H_{s, T m}$ \\
SD & 2 & ADP & 1297 & $12 / 24 / 99$ & $2109: 34$ & $H_{s, T m}$ \\
SD & 2 & ADP & 1509 & $12 / 29 / 99$ & $0709: 34$ & $H_{s, T m}$ \\
\hline
\end{tabular}


Table 13. Data statistics from Deployments 1, 2, and the entire deployment.

\begin{tabular}{|c|c|c|c|c|c|c|c|c|}
\hline Site & Dep \# & System & Variable & Mean & $\begin{array}{l}\text { Std. } \\
\text { Dev. }\end{array}$ & Min & $\operatorname{Max}$ & $\begin{array}{c}\text { \# of } \\
\text { Data } \\
\text { Points }\end{array}$ \\
\hline \multirow[t]{46}{*}{ ND } & 1 & ADV & Pressure (dbar) & 24.49 & 0.81 & 22.67 & 26.29 & 386 \\
\hline & & & Temperature $\left({ }^{\circ} \mathrm{C}\right)$ & 9.64 & 1.04 & 7.95 & 11.25 & 386 \\
\hline & & & Velocity - East (cm/s) & -2.93 & 5.90 & -23.02 & 9.77 & 386 \\
\hline & & & Velocity - North $(\mathrm{cm} / \mathrm{s})$ & 0.09 & 8.03 & -17.31 & 56.80 & 386 \\
\hline & & & Speed $(\mathrm{cm} / \mathrm{s})$ & 7.66 & 7.02 & 0.14 & 60.40 & 386 \\
\hline & & & Velocity - Up (cm/s) & -0.07 & 0.73 & -5.59 & 1.53 & 386 \\
\hline & & & Distance to Bottom $(\mathrm{cm})$ & 62.22 & 11.88 & 32.08 & 80.21 & 352 \\
\hline & & & Turbidity (NTU) & 22.13 & 19.61 & 1.93 & 113.71 & 386 \\
\hline & & ADP & Pressure (dbar) & 22.78 & 0.81 & 20.91 & 24.69 & 1543 \\
\hline & & & Temperature $\left({ }^{\circ} \mathrm{C}\right)$ & 9.65 & 1.04 & 7.94 & 11.27 & 1543 \\
\hline & & & Cell 1 Velocity - East (cm/s) & -2.52 & 9.60 & -39.41 & 20.82 & 1543 \\
\hline & & & Cell 1Velocity - North (cm/s) & 1.24 & 12.27 & -25.76 & 76.36 & 1543 \\
\hline & & & Cell 1Speed (cm/s) & 12.80 & 9.31 & 0.22 & 76.77 & 1543 \\
\hline & & & Cell 1Velocity - Up (cm/s) & -0.64 & 0.82 & -4.80 & 3.20 & 1543 \\
\hline & & & Cell 2 Velocity - East (cm/s) & -2.80 & 10.76 & -41.78 & 23.96 & 1543 \\
\hline & & & Cell 2 Velocity - North (cm/s) & 1.31 & 13.99 & -27.08 & 82.11 & 1543 \\
\hline & & & Cell 2 Speed $(\mathrm{cm} / \mathrm{s})$ & 14.81 & 10.08 & 0.22 & 82.48 & 1543 \\
\hline & & & Cell 2 Velocity - Up (cm/s) & -0.54 & 0.53 & -4.90 & 0.70 & 1543 \\
\hline & & & Cell 20 Velocity - East $(\mathrm{cm} / \mathrm{s})$ & 0.87 & 8.28 & -37.24 & 23.50 & 1543 \\
\hline & & & Cell 20 Velocity - North $(\mathrm{cm} / \mathrm{s})$ & 3.40 & 23.75 & -42.10 & 110.76 & 1543 \\
\hline & & & Cell 20 Speed $(\mathrm{cm} / \mathrm{s})$ & 20.51 & 14.97 & 0.40 & 111.32 & 1543 \\
\hline & & & Cell 20 Velocity - Up (cm/s) & -0.71 & 0.41 & -3.90 & 1.00 & 1543 \\
\hline & & & Cell 36 Velocity - East $(\mathrm{cm} / \mathrm{s})$ & -0.48 & 9.14 & -31.98 & 30.41 & 1543 \\
\hline & & & Cell 36 Velocity - North $(\mathrm{cm} / \mathrm{s})$ & 6.86 & 28.77 & -41.55 & 119.84 & 1543 \\
\hline & & & Cell 36 Speed $(\mathrm{cm} / \mathrm{s})$ & 25.00 & 18.25 & 0.40 & 120.32 & 1543 \\
\hline & & & Cell 36 Velocity - Up (cm/s) & -2.41 & 1.57 & -9.20 & 0.00 & 1543 \\
\hline & & & $H_{S}(\mathrm{~cm})$ & 253.38 & 134.94 & 70.80 & 968.10 & 772 \\
\hline & & & $T_{m}(\mathrm{~s})$ & 10.22 & 2.44 & 6.60 & 20.00 & 772 \\
\hline & 2 & ADV & Pressure (dbar) & 24.97 & 0.82 & 22.85 & 26.87 & 883 \\
\hline & & & Temperature $\left({ }^{\circ} \mathrm{C}\right)$ & 10.92 & 0.19 & 10.20 & 11.41 & 883 \\
\hline & & & Velocity - East (cm/s) & -2.28 & 4.95 & -25.68 & 10.33 & 883 \\
\hline & & & Velocity - North (cm/s) & 0.70 & 7.82 & -21.88 & 48.04 & 883 \\
\hline & & & Speed $(\mathrm{cm} / \mathrm{s})$ & 6.88 & 6.63 & 0.10 & 54.47 & 883 \\
\hline & & & Velocity - Up (cm/s) & 0.22 & 0.64 & -2.45 & 1.79 & 883 \\
\hline & & & Distance to Bottom (cm) & 51.59 & 9.79 & 34.09 & 83.65 & 654 \\
\hline & & & Turbidity (NTU) & 43.09 & 31.96 & 1.11 & 195.07 & 883 \\
\hline & & ADP & Pressure (dbar) & 24.24 & 0.84 & 21.97 & 26.17 & 2623 \\
\hline & & & Temperature $\left({ }^{\circ} \mathrm{C}\right)$ & 10.81 & 0.24 & 9.49 & 11.41 & 2623 \\
\hline & & & Cell 1 Velocity - East (cm/s) & -1.13 & 8.95 & -35.96 & 23.17 & 2623 \\
\hline & & & Cell 1 Velocity - North $(\mathrm{cm} / \mathrm{s})$ & 2.41 & 12.55 & -37.45 & 72.24 & 2623 \\
\hline & & & Cell 1 Speed $(\mathrm{cm} / \mathrm{s})$ & 12.97 & 8.74 & 0.30 & 72.25 & 2623 \\
\hline & & & Cell 1 Velocity - Up (cm/s) & -0.70 & 0.78 & -4.20 & 2.20 & 2623 \\
\hline & & & Cell 2 Velocity - East (cm/s) & -1.66 & 9.99 & -40.83 & 27.21 & 2623 \\
\hline & & & Cell 2 Velocity - North $(\mathrm{cm} / \mathrm{s})$ & 3.06 & 14.27 & -37.63 & 76.93 & 2623 \\
\hline & & & Cell 2 Speed $(\mathrm{cm} / \mathrm{s})$ & 14.81 & 9.80 & 0.20 & 76.95 & 2623 \\
\hline & & & Cell 2 Velocity - Up (cm/s) & -0.59 & 0.49 & -2.90 & 1.20 & 2623 \\
\hline
\end{tabular}


Table 13. Data statistics from Deployments 1, 2, and the entire deployment. (Continued)

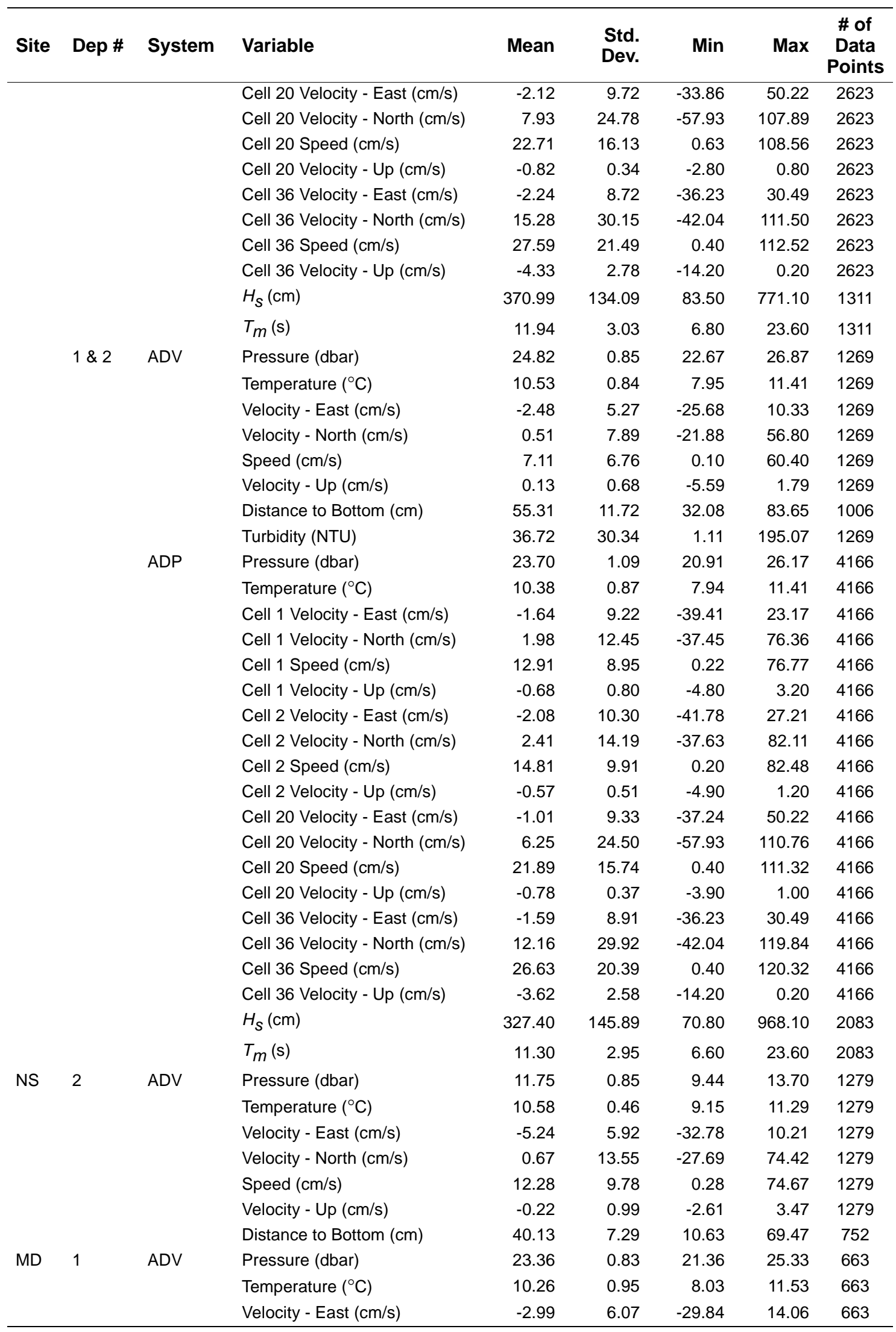


Table 13. Data statistics from Deployments 1, 2, and the entire deployment. (Continued)

\begin{tabular}{|c|c|c|c|c|c|c|c|c|}
\hline Site & Dep \# & System & Variable & Mean & $\begin{array}{l}\text { Std. } \\
\text { Dev. }\end{array}$ & Min & Max & $\begin{array}{c}\text { \# of } \\
\text { Data } \\
\text { Points }\end{array}$ \\
\hline & & & Velocity - North $(\mathrm{cm} / \mathrm{s})$ & 4.81 & 13.77 & -24.51 & 92.16 & 663 \\
\hline & & & Speed $(\mathrm{cm} / \mathrm{s})$ & 11.10 & 11.63 & 0.13 & 92.27 & 663 \\
\hline & & & Velocity - Up (cm/s) & 0.37 & 1.81 & -21.16 & 2.19 & 663 \\
\hline & & & Distance to Bottom $(\mathrm{cm})$ & 48.66 & 14.01 & 23.82 & 83.36 & 567 \\
\hline & & & Turbidity (NTU) & 32.28 & 24.25 & 0.36 & 156.50 & 663 \\
\hline & 2 & ADV & Pressure (dbar) & 23.54 & 0.83 & 21.26 & 25.33 & 766 \\
\hline & & & Temperature $\left({ }^{\circ} \mathrm{C}\right)$ & 10.81 & 0.24 & 9.62 & 11.27 & 766 \\
\hline & & & Velocity - East (cm/s) & -1.09 & 7.58 & -27.81 & 28.42 & 766 \\
\hline & & & Velocity - North $(\mathrm{cm} / \mathrm{s})$ & 3.89 & 10.20 & -21.04 & 59.51 & 766 \\
\hline & & & Speed $(\mathrm{cm} / \mathrm{s})$ & 10.53 & 8.17 & 0.56 & 59.51 & 766 \\
\hline & & & Velocity - Up (cm/s) & -0.28 & 0.83 & -3.04 & 1.70 & 766 \\
\hline & & & Distance to Bottom $(\mathrm{cm})$ & 49.27 & 5.22 & 15.97 & 80.47 & 574 \\
\hline & & & Turbidity (NTU) & 38.93 & 25.80 & 2.29 & 201.11 & 766 \\
\hline & $1 \& 2$ & ADV & Pressure (dbar) & 23.45 & 0.84 & 21.26 & 25.33 & 1429 \\
\hline & & & Temperature $\left({ }^{\circ} \mathrm{C}\right)$ & 10.56 & 0.72 & 8.03 & 11.53 & 1429 \\
\hline & & & Velocity - East (cm/s) & -1.97 & 6.98 & -29.84 & 28.42 & 1429 \\
\hline & & & Velocity - North $(\mathrm{cm} / \mathrm{s})$ & 4.32 & 12.00 & -24.51 & 92.16 & 1429 \\
\hline & & & Speed $(\mathrm{cm} / \mathrm{s})$ & 10.79 & 9.93 & 0.13 & 92.27 & 1429 \\
\hline & & & Velocity - Up (cm/s) & 0.02 & 1.41 & -21.16 & 2.19 & 1429 \\
\hline & & & Distance to Bottom $(\mathrm{cm})$ & 48.96 & 10.55 & 15.97 & 83.36 & 1141 \\
\hline & & & Turbidity (NTU) & 35.85 & 25.31 & 0.36 & 201.11 & 1429 \\
\hline \multirow[t]{6}{*}{ MS } & 1 & Seagauge & Pressure (psia) & 18.59 & 1.20 & 15.89 & 21.60 & 2308 \\
\hline & & & Temperature $\left({ }^{\circ} \mathrm{C}\right)$ & 10.28 & 0.82 & 8.51 & 11.71 & 2308 \\
\hline & 2 & Seagauge & Pressure (psia) & 19.15 & 1.22 & 15.82 & 21.99 & 3930 \\
\hline & & & Temperature $\left({ }^{\circ} \mathrm{C}\right)$ & 10.63 & 0.44 & 8.78 & 11.24 & 3930 \\
\hline & $1 \& 2$ & Seagauge & Pressure (psia) & 18.95 & 1.24 & 15.82 & 21.99 & 6238 \\
\hline & & & Temperature $\left({ }^{\circ} \mathrm{C}\right)$ & 10.50 & 0.63 & 8.51 & 11.71 & 6238 \\
\hline \multirow[t]{21}{*}{ SD } & 1 & ADV & Pressure (dbar) & 23.27 & 0.84 & 21.29 & 25.30 & 663 \\
\hline & & & Temperature $\left({ }^{\circ} \mathrm{C}\right)$ & 10.02 & 1.16 & 7.80 & 11.41 & 664 \\
\hline & & & Velocity - East $(\mathrm{cm} / \mathrm{s})$ & -4.57 & 8.44 & -41.43 & 15.48 & 664 \\
\hline & & & Velocity - North $(\mathrm{cm} / \mathrm{s})$ & 5.54 & 11.96 & -17.85 & 70.23 & 664 \\
\hline & & & Speed $(\mathrm{cm} / \mathrm{s})$ & 11.52 & 11.53 & 0.16 & 75.44 & 664 \\
\hline & & & Velocity - Up (cm/s) & 0.34 & 0.89 & -3.75 & 2.14 & 664 \\
\hline & & & Distance to Bottom $(\mathrm{cm})$ & 54.56 & 10.70 & 31.17 & 82.30 & 623 \\
\hline & & & Turbidity (NTU) & 12.82 & 11.98 & -1.35 & 80.78 & 664 \\
\hline & & ADP & Pressure (dbar) & 21.26 & 0.83 & 19.16 & 23.36 & 2374 \\
\hline & & & Temperature $\left({ }^{\circ} \mathrm{C}\right)$ & 10.11 & 1.16 & 7.88 & 11.50 & 2653 \\
\hline & & & Cell 1 Velocity - East $(\mathrm{cm} / \mathrm{s})$ & -5.24 & 13.32 & -61.46 & 23.77 & 2653 \\
\hline & & & Cell 1 Velocity - North $(\mathrm{cm} / \mathrm{s})$ & 6.16 & 13.21 & -32.43 & 78.90 & 2653 \\
\hline & & & Cell 1 Speed $(\mathrm{cm} / \mathrm{s})$ & 16.24 & 12.40 & 0.00 & 95.25 & 2653 \\
\hline & & & Cell 1 Velocity - Up (cm/s) & -0.03 & 1.01 & -6.20 & 4.20 & 2653 \\
\hline & & & Cell 2 Velocity - East $(\mathrm{cm} / \mathrm{s})$ & -5.66 & 14.89 & -64.44 & 27.60 & 2653 \\
\hline & & & Cell 2 Velocity - North $(\mathrm{cm} / \mathrm{s})$ & 7.46 & 15.32 & -36.58 & 84.20 & 2653 \\
\hline & & & Cell 2 Speed $(\mathrm{cm} / \mathrm{s})$ & 18.87 & 13.70 & 0.54 & 100.88 & 2653 \\
\hline & & & Cell 2 Velocity - Up (cm/s) & -0.21 & 0.65 & -3.30 & 1.90 & 2653 \\
\hline & & & Cell 20 Velocity - East (cm/s) & -3.54 & 16.78 & -63.41 & 39.63 & 2653 \\
\hline & & & Cell 20 Velocity - North $(\mathrm{cm} / \mathrm{s})$ & 13.67 & 22.72 & -43.19 & 111.63 & 2653 \\
\hline & & & Cell 20 Speed $(\mathrm{cm} / \mathrm{s})$ & 26.22 & 17.60 & 0.81 & 122.35 & 2653 \\
\hline
\end{tabular}


Table 13. Data statistics from Deployments 1, 2, and the entire deployment. (Continued)

\begin{tabular}{|c|c|c|c|c|c|c|c|c|}
\hline Site & Dep \# & System & Variable & Mean & $\begin{array}{l}\text { Std. } \\
\text { Dev. }\end{array}$ & Min & Max & $\begin{array}{c}\text { \# of } \\
\text { Data } \\
\text { Points }\end{array}$ \\
\hline & & & Cell 20 Velocity - Up (cm/s) & -1.66 & 0.88 & -7.80 & 0.50 & 2653 \\
\hline & & & Cell 36 Velocity - East (cm/s) & -12.79 & 17.15 & -65.48 & 38.17 & 2653 \\
\hline & & & Cell 36 Velocity - North $(\mathrm{cm} / \mathrm{s})$ & 16.17 & 25.67 & -60.44 & 116.12 & 2653 \\
\hline & & & Cell 36 Speed $(\mathrm{cm} / \mathrm{s})$ & 31.58 & 19.50 & 0.22 & 126.37 & 2653 \\
\hline & & & Cell 36 Velocity - Up (cm/s) & -6.94 & 3.71 & -22.40 & -0.50 & 2653 \\
\hline & & & $H_{S}(\mathrm{~cm})$ & 295.00 & 135.92 & 64.40 & 925.30 & 1185 \\
\hline & & & $T_{m}(\mathrm{~s})$ & 10.22 & 2.36 & 6.00 & 19.00 & 1180 \\
\hline \multirow{28}{*}{\multicolumn{2}{|c|}{2}} & ADV & Pressure (dbar) & 23.31 & 0.83 & 21.07 & 25.14 & 755 \\
\hline & & & Temperature $\left({ }^{\circ} \mathrm{C}\right)$ & 10.75 & 0.30 & 9.45 & 12.27 & 755 \\
\hline & & & Velocity - East (cm/s) & -6.07 & 10.04 & -55.37 & 21.36 & 755 \\
\hline & & & Velocity - North (cm/s) & 4.65 & 10.81 & -28.26 & 51.18 & 755 \\
\hline & & & Speed $(\mathrm{cm} / \mathrm{s})$ & 12.33 & 11.13 & 0.23 & 68.69 & 755 \\
\hline & & & Velocity - Up (cm/s) & -0.04 & 1.03 & -5.68 & 1.92 & 755 \\
\hline & & & Distance to Bottom (cm) & 66.16 & 6.56 & 54.49 & 95.96 & 672 \\
\hline & & & Turbidity (NTU) & 15.56 & 17.02 & -0.66 & 134.62 & 755 \\
\hline & & ADP & Pressure (dbar) & 21.31 & 0.84 & 19.09 & 23.25 & 1509 \\
\hline & & & Temperature $\left({ }^{\circ} \mathrm{C}\right)$ & 10.83 & 0.30 & 9.51 & 11.35 & 1509 \\
\hline & & & Cell 1 Velocity - East $(\mathrm{cm} / \mathrm{s})$ & -6.13 & 15.02 & -65.13 & 36.22 & 1509 \\
\hline & & & Cell 1 Velocity - North $(\mathrm{cm} / \mathrm{s})$ & 5.88 & 13.27 & -34.59 & 60.00 & 1509 \\
\hline & & & Cell 1 Speed $(\mathrm{cm} / \mathrm{s})$ & 17.73 & 12.62 & 0.28 & 76.75 & 1509 \\
\hline & & & Cell 1 Velocity - Up (cm/s) & 0.45 & 1.16 & -8.40 & 4.70 & 1509 \\
\hline & & & Cell 2 Velocity - East (cm/s) & -7.03 & 16.71 & -67.88 & 45.02 & 1509 \\
\hline & & & Cell 2 Velocity - North $(\mathrm{cm} / \mathrm{s})$ & 6.72 & 15.32 & -39.77 & 64.25 & 1509 \\
\hline & & & Cell 2 Speed (cm/s) & 20.52 & 13.68 & 0.28 & 80.55 & 1509 \\
\hline & & & Cell 2 Velocity - Up (cm/s) & 0.16 & 0.69 & -4.00 & 3.00 & 1509 \\
\hline & & & Cell 20 Velocity - East (cm/s) & -9.99 & 18.51 & -80.25 & 41.65 & 1509 \\
\hline & & & Cell 20 Velocity - North $(\mathrm{cm} / \mathrm{s})$ & 17.24 & 23.44 & -37.56 & 91.17 & 1509 \\
\hline & & & Cell 20 Speed $(\mathrm{cm} / \mathrm{s})$ & 29.36 & 20.66 & 0.20 & 110.19 & 1509 \\
\hline & & & Cell 20 Velocity - Up (cm/s) & -1.39 & 0.65 & -5.90 & 1.50 & 1509 \\
\hline & & & Cell 36 Velocity - East (cm/s) & -22.42 & 16.28 & -80.52 & 36.64 & 1509 \\
\hline & & & Cell 36 Velocity - North $(\mathrm{cm} / \mathrm{s})$ & 22.59 & 23.30 & -42.64 & 95.73 & 1509 \\
\hline & & & Cell 36 Speed $(\mathrm{cm} / \mathrm{s})$ & 37.48 & 20.40 & 0.95 & 125.09 & 1509 \\
\hline & & & Cell 36 Velocity - Up (cm/s) & -8.68 & 3.54 & -20.00 & -0.60 & 1509 \\
\hline & & & $H_{S}(\mathrm{~cm})$ & 357.09 & 138.78 & 78.00 & 740.60 & 751 \\
\hline & & & $T_{m}(\mathrm{~s})$ & 12.08 & 3.11 & 6.50 & 23.40 & 751 \\
\hline & $1 \& 2$ & ADV & Pressure (dbar) & 23.29 & 0.84 & 21.07 & 25.30 & 1418 \\
\hline & & & Temperature $\left({ }^{\circ} \mathrm{C}\right)$ & 10.41 & 0.90 & 7.80 & 12.27 & 1419 \\
\hline & & & Velocity - East (cm/s) & -5.37 & 9.36 & -55.37 & 21.36 & 1419 \\
\hline & & & Velocity - North (cm/s) & 5.07 & 11.36 & -28.26 & 70.23 & 1419 \\
\hline & & & Speed $(\mathrm{cm} / \mathrm{s})$ & 11.95 & 11.32 & 0.16 & 75.44 & 1419 \\
\hline & & & Velocity - Up (cm/s) & 0.14 & 0.99 & -5.68 & 2.14 & 1419 \\
\hline & & & Distance to Bottom (cm) & 52.35 & 9.05 & 31.17 & 82.30 & 1295 \\
\hline & & & Turbidity (NTU) & 14.28 & 14.93 & -1.35 & 134.62 & 1419 \\
\hline & & ADP & Pressure (dbar) & 21.28 & 0.84 & 19.09 & 23.36 & 3883 \\
\hline & & & Temperature $\left({ }^{\circ} \mathrm{C}\right)$ & 10.37 & 1.01 & 7.88 & 11.50 & 4162 \\
\hline & & & Cell 1 Velocity - East $(\mathrm{cm} / \mathrm{s})$ & -5.56 & 13.96 & -65.13 & 36.22 & 4162 \\
\hline & & & Cell 1 Velocity - North $(\mathrm{cm} / \mathrm{s})$ & 6.06 & 13.23 & -34.59 & 78.90 & 4162 \\
\hline & & & Cell 1 Speed $(\mathrm{cm} / \mathrm{s})$ & 16.78 & 12.50 & 0.00 & 95.25 & 4162 \\
\hline
\end{tabular}


Table 13. Data statistics from Deployments 1, 2, and the entire deployment. (Continued)

\begin{tabular}{|c|c|c|c|c|c|c|c|c|}
\hline Site & Dep \# & System & Variable & Mean & $\begin{array}{l}\text { Std. } \\
\text { Dev. }\end{array}$ & Min & Max & $\begin{array}{c}\text { \# of } \\
\text { Data } \\
\text { Points }\end{array}$ \\
\hline & & & Cell 1 Velocity - Up (cm/s) & 0.14 & 1.09 & -8.40 & 4.70 & 4162 \\
\hline & & & Cell 2 Velocity - East $(\mathrm{cm} / \mathrm{s})$ & -6.16 & 15.59 & -67.88 & 45.02 & 4162 \\
\hline & & & Cell 2 Velocity - North $(\mathrm{cm} / \mathrm{s})$ & 7.19 & 15.32 & -39.77 & 84.20 & 4162 \\
\hline & & & Cell 2 Speed $(\mathrm{cm} / \mathrm{s})$ & 19.47 & 13.71 & 0.28 & 100.88 & 4162 \\
\hline & & & Cell 2 Velocity - Up (cm/s) & -0.08 & 0.69 & -4.00 & 3.00 & 4162 \\
\hline & & & Cell 20 Velocity - East $(\mathrm{cm} / \mathrm{s})$ & -5.88 & 17.70 & -80.25 & 41.65 & 4162 \\
\hline & & & Cell 20 Velocity - North $(\mathrm{cm} / \mathrm{s})$ & 14.97 & 23.04 & -43.19 & 111.63 & 4162 \\
\hline & & & Cell 20 Speed $(\mathrm{cm} / \mathrm{s})$ & 27.36 & 18.82 & 0.20 & 122.35 & 4162 \\
\hline & & & Cell 20 Velocity - Up (cm/s) & -1.56 & 0.81 & -7.80 & 1.50 & 4162 \\
\hline & & & Cell 36 Velocity - East $(\mathrm{cm} / \mathrm{s})$ & -16.28 & 17.46 & -80.52 & 38.17 & 4162 \\
\hline & & & Cell 36 Velocity - North $(\mathrm{cm} / \mathrm{s})$ & 18.50 & 25.02 & -60.44 & 116.12 & 4162 \\
\hline & & & Cell 36 Speed $(\mathrm{cm} / \mathrm{s})$ & 33.72 & 20.03 & 0.22 & 126.37 & 4162 \\
\hline & & & Cell 36 Velocity - Up (cm/s) & -7.57 & 3.75 & -22.40 & -0.50 & 4162 \\
\hline & & & $H_{S}(\mathrm{~cm})$ & 319.08 & 140.30 & 64.40 & 925.30 & 1936 \\
\hline & & & $T_{m}(\mathrm{~s})$ & 10.94 & 2.82 & 6.00 & 23.40 & 1931 \\
\hline \multirow[t]{24}{*}{ SS } & 1 & ADV & Pressure (dbar) & 16.39 & 0.85 & 14.52 & 18.44 & 663 \\
\hline & & & Temperature $\left({ }^{\circ} \mathrm{C}\right)$ & 10.28 & 1.06 & 7.89 & 11.54 & 663 \\
\hline & & & Velocity - East (cm/s) & -5.13 & 10.90 & -74.79 & 19.11 & 663 \\
\hline & & & Velocity - North $(\mathrm{cm} / \mathrm{s})$ & 9.17 & 14.33 & -30.71 & 86.49 & 663 \\
\hline & & & Speed $(\mathrm{cm} / \mathrm{s})$ & 16.11 & 13.22 & 0.57 & 93.22 & 663 \\
\hline & & & Velocity - Up (cm/s) & -0.03 & 1.11 & -6.60 & 2.24 & 663 \\
\hline & & & Distance to Bottom $(\mathrm{cm})$ & 49.45 & 11.07 & 28.84 & 83.11 & 589 \\
\hline & & & Turbidity (NTU) & 7.21 & 10.11 & -2.14 & 59.35 & 663 \\
\hline & 2 & ADV & Pressure (dbar) & 16.67 & 0.83 & 14.41 & 18.49 & 754 \\
\hline & & & Temperature $\left({ }^{\circ} \mathrm{C}\right)$ & 10.57 & 0.37 & 9.48 & 11.26 & 754 \\
\hline & & & Velocity - East (cm/s) & -7.96 & 11.30 & -58.62 & 19.23 & 754 \\
\hline & & & Velocity - North $(\mathrm{cm} / \mathrm{s})$ & 9.19 & 13.11 & -25.30 & 53.71 & 754 \\
\hline & & & Speed $(\mathrm{cm} / \mathrm{s})$ & 16.69 & 13.00 & 0.54 & 66.94 & 754 \\
\hline & & & Velocity - Up (cm/s) & 0.58 & 0.96 & -3.20 & 2.32 & 754 \\
\hline & & & Distance to Bottom $(\mathrm{cm})$ & 65.40 & 11.07 & 44.79 & 99.06 & 643 \\
\hline & & & Turbidity (NTU) & 10.41 & 11.18 & -2.12 & 69.27 & 754 \\
\hline & $1 \& 2$ & ADV & Pressure (dbar) & 16.54 & 0.85 & 14.41 & 18.49 & 1417 \\
\hline & & & Temperature $\left({ }^{\circ} \mathrm{C}\right)$ & 10.44 & 0.79 & 7.89 & 11.54 & 1417 \\
\hline & & & Velocity - East $(\mathrm{cm} / \mathrm{s})$ & -6.64 & 11.20 & -74.79 & 19.23 & 1417 \\
\hline & & & Velocity - North $(\mathrm{cm} / \mathrm{s})$ & 9.18 & 13.69 & -30.71 & 86.49 & 1417 \\
\hline & & & Speed $(\mathrm{cm} / \mathrm{s})$ & 16.42 & 13.10 & 0.54 & 93.22 & 1417 \\
\hline & & & Velocity - Up (cm/s) & 0.29 & 1.08 & -6.60 & 2.32 & 1417 \\
\hline & & & Distance to Bottom $(\mathrm{cm})$ & 56.04 & 13.01 & 23.62 & 83.11 & 1232 \\
\hline & & & Turbidity (NTU) & 8.91 & 10.81 & -2.14 & 69.27 & 1417 \\
\hline
\end{tabular}


Figures 15 through 70 show raw data collected by the Hydra system and ADP. Deployment 1 and 2 data are plotted together (where applicable). The time at which each time series point is plotted has been adjusted to represent the center of the burst. Therefore, if a burst started at 7.5 minutes before the hour, and the burst lasted 900 seconds (15 minutes), then 7.5 minutes were added to the start time and the burst was plotted on the hour. Distance to the bottom is the distance from the center of the ADVOcean sampling volume to the bed, as measured by the ADVOcean. Heights listed as meters above bed (mab) are nominal.

East and north velocity and heading data were corrected for magnetic north before plotting. Magnetic declination in the Grays Harbor area is $19^{\circ}$. Speed and direction are calculated using these corrected values.

Pressure data were adjusted by removing an approximate value for atmospheric pressure. For Sites ND, MD, SD, and SS, 10.209 dbar were subtracted from the data. In the case of NS, where a strain gauge was used to measure the pressure, $0.19 \mathrm{dbar}$ were subtracted from the data.

Data collected while the tripod was not on the bottom for the entire burst were removed from the beginning and end of the data series before plotting. Pressure and wave data collected while the pressure sensor on the ADP at Site SD was not working correctly, at the beginning of Deployment 1 (Table 12), were removed before plotting. Other flagged data points (Table 12) were not removed before plotting.

Turbidity was calculated using the conversions detailed in Appendix D. Suspended sediment concentration was calculated using a calibration curve which was obtained using sand from northern California. The OBS response (counts) was first converted to volts using the conversions in Appendix $\mathrm{D}$ and then the values in volts were converted to suspended sediment concentration $C_{\mathrm{S}}$ $(\mathrm{g} / \mathrm{L})$ using the equation $C_{s}=4.308 \cdot 10^{-7} \cdot(\text { volts })^{2}+0.00192 \cdot$ (volts $)+0.009$.

A low-pass filter was applied to the ADV and ADP corrected velocity data to smooth the data and remove frequencies greater than 40 hours before plotting as low-pass filtered velocity data. These data were also decimated to 6 hour intervals.

Cumulative transport plots (i.e. Figure $21 \mathrm{~b}$ and $\mathrm{c}$ ) were generated by multiplying the mean north and east velocity components (alongshore and cross-shore, respectively) by the length of the burst from which the average was taken, i.e. $2048 \mathrm{~s}$ for ADVOcean data and $900 \mathrm{~s}$ for ADP data, resulting in the distance travelled during that burst. By cumulatively summing these distances, a cumulative transport distance was obtained and plotted versus time.

Cumulative suspended sediment transport plots (i.e. Figure $22 \mathrm{~b}$ and $\mathrm{c}$ ) were obtained by multiplying the north and east velocity components by the length of the burst and then multiplying by the average suspended sediment concentration associated with that burst. These values were then cumulatively summed and plotted versus time to obtain the alongshore and cross-shore plots.

The east and north cumulative transport distances were plotted versus each other to obtain the progressive vector plots (i.e. Figure 31). 


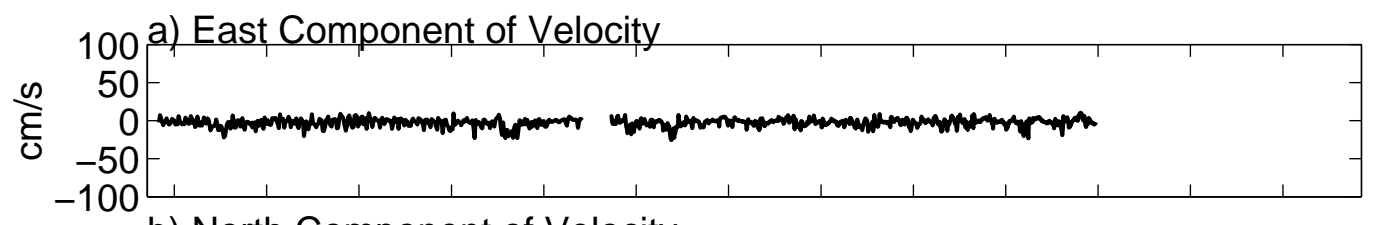

100 b) North Component of Velocity
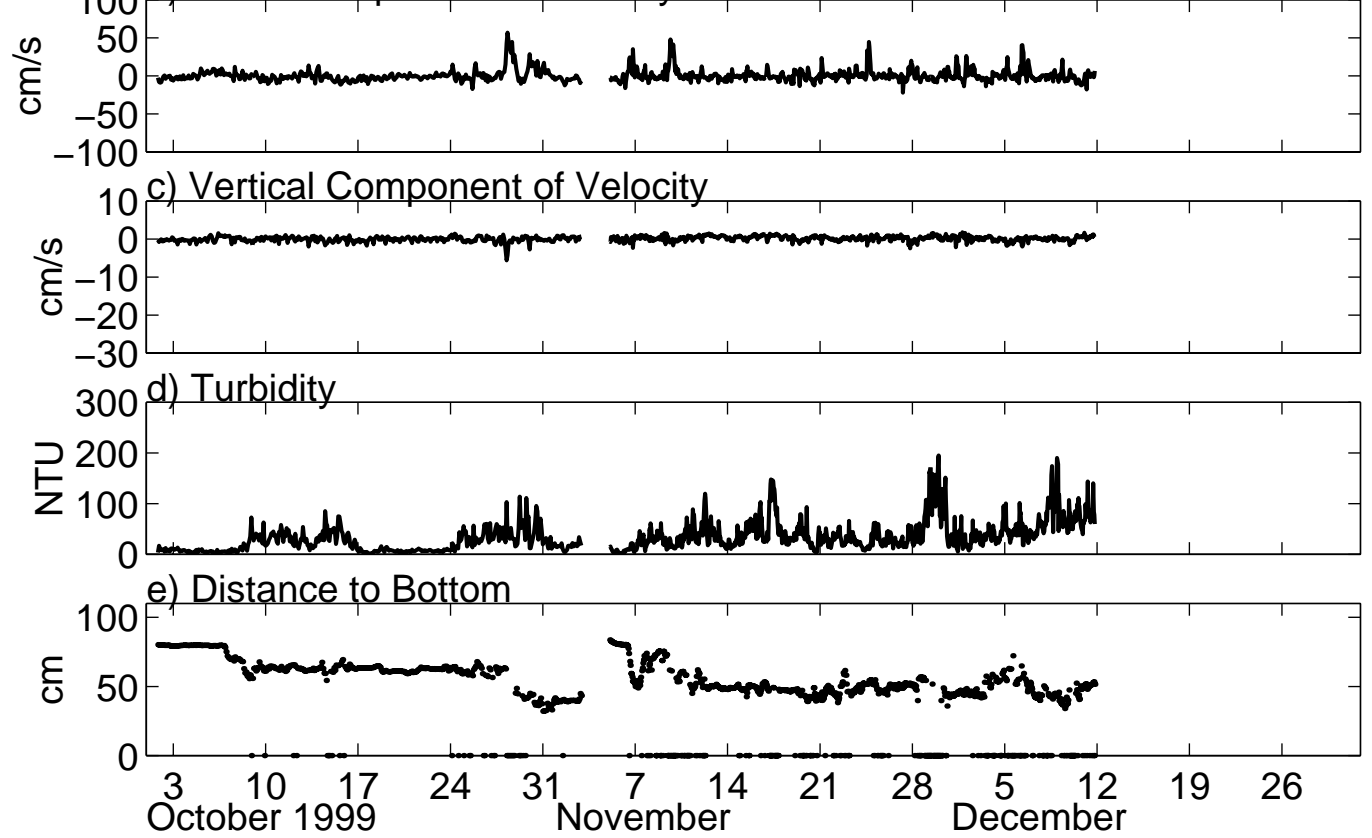

Figure 15. Time series of east (positive eastward), north (positive northward), and vertical (positive up) velocity components, turbidity, and distance to the bottom from data collected by the ADV at Site ND. 

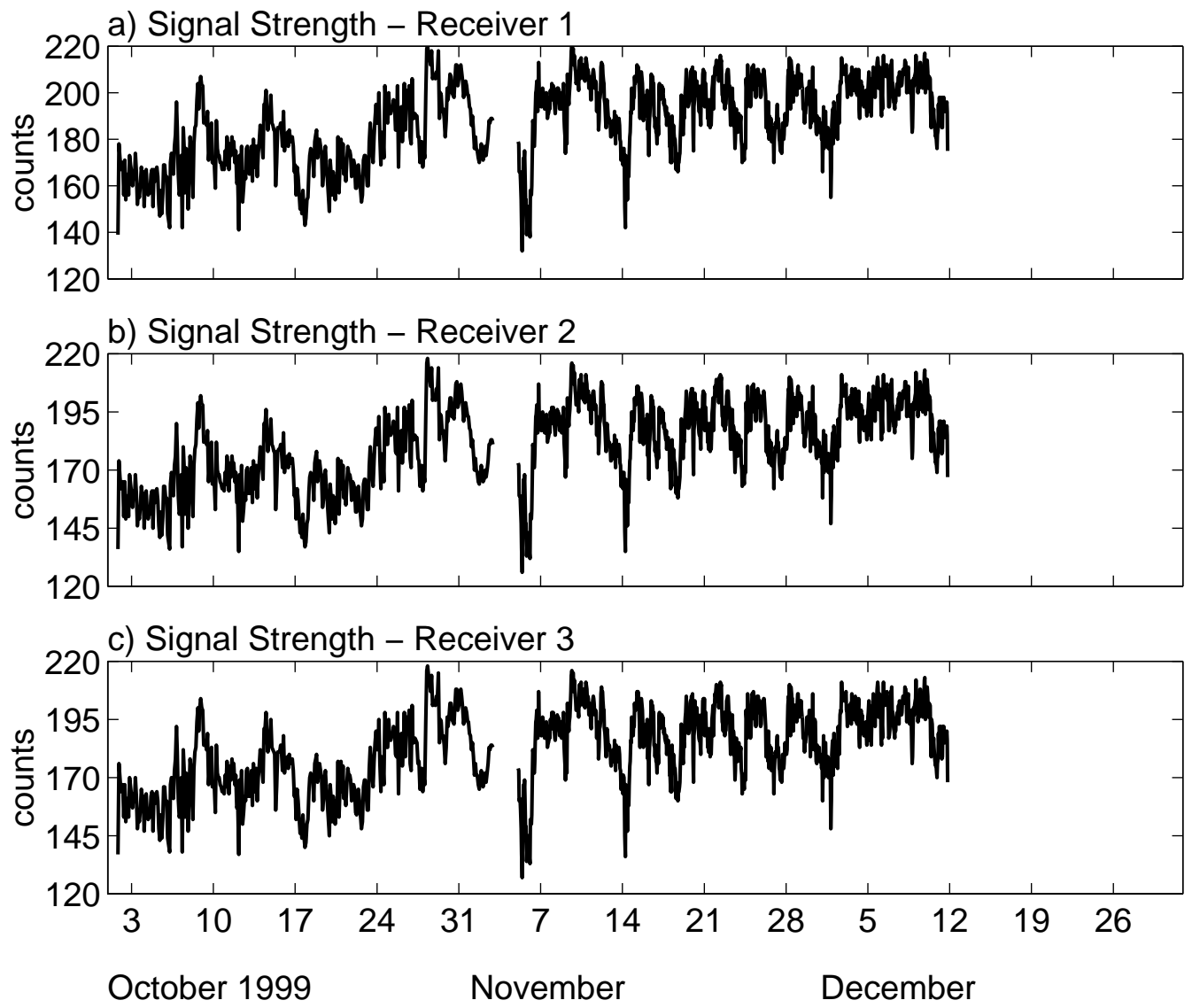

Figure 16. Time series of signal strength collected for each ADV receiver at Site ND. 

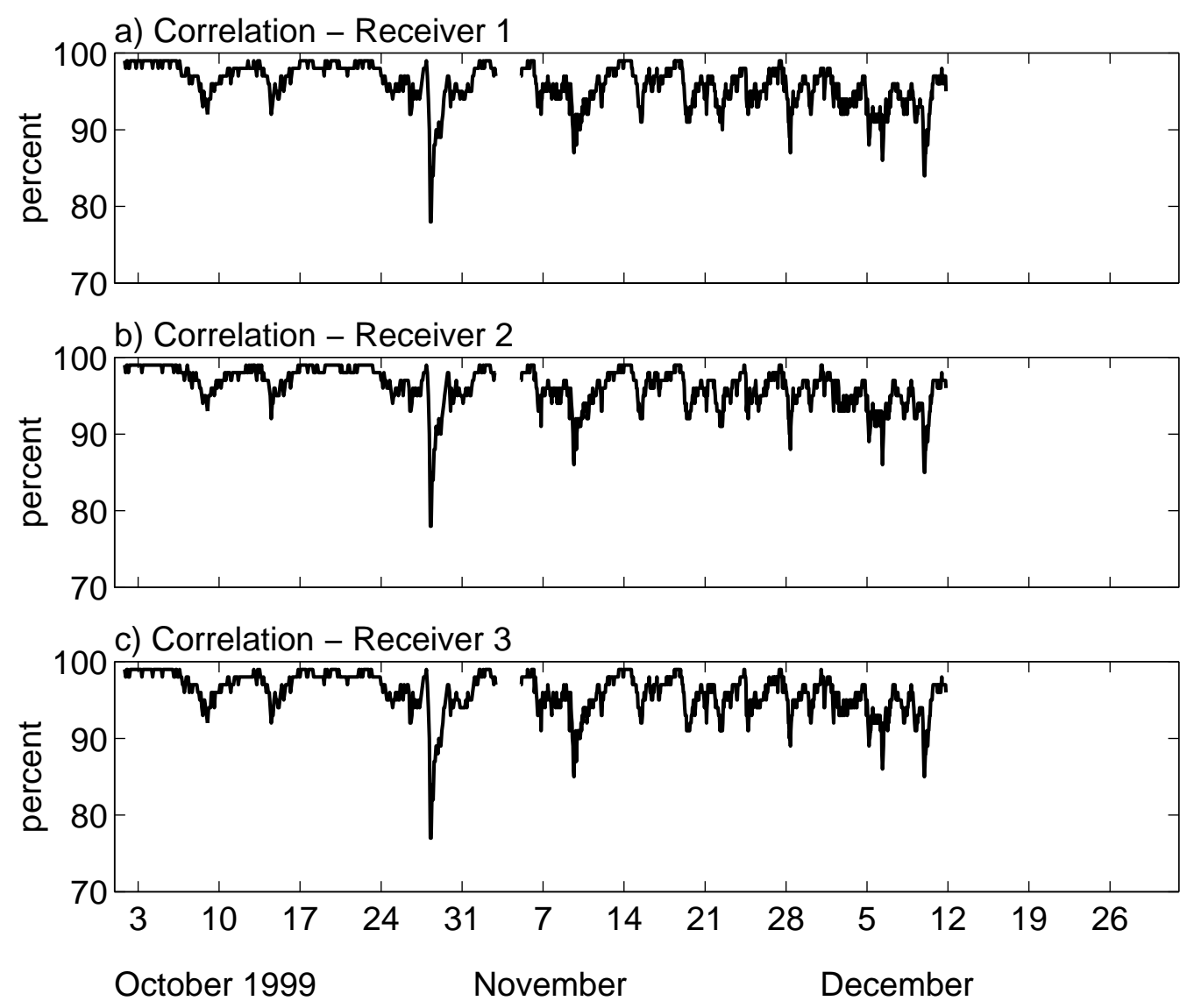

Figure 17. Time series of signal correlation for ADV receivers at Site ND. 

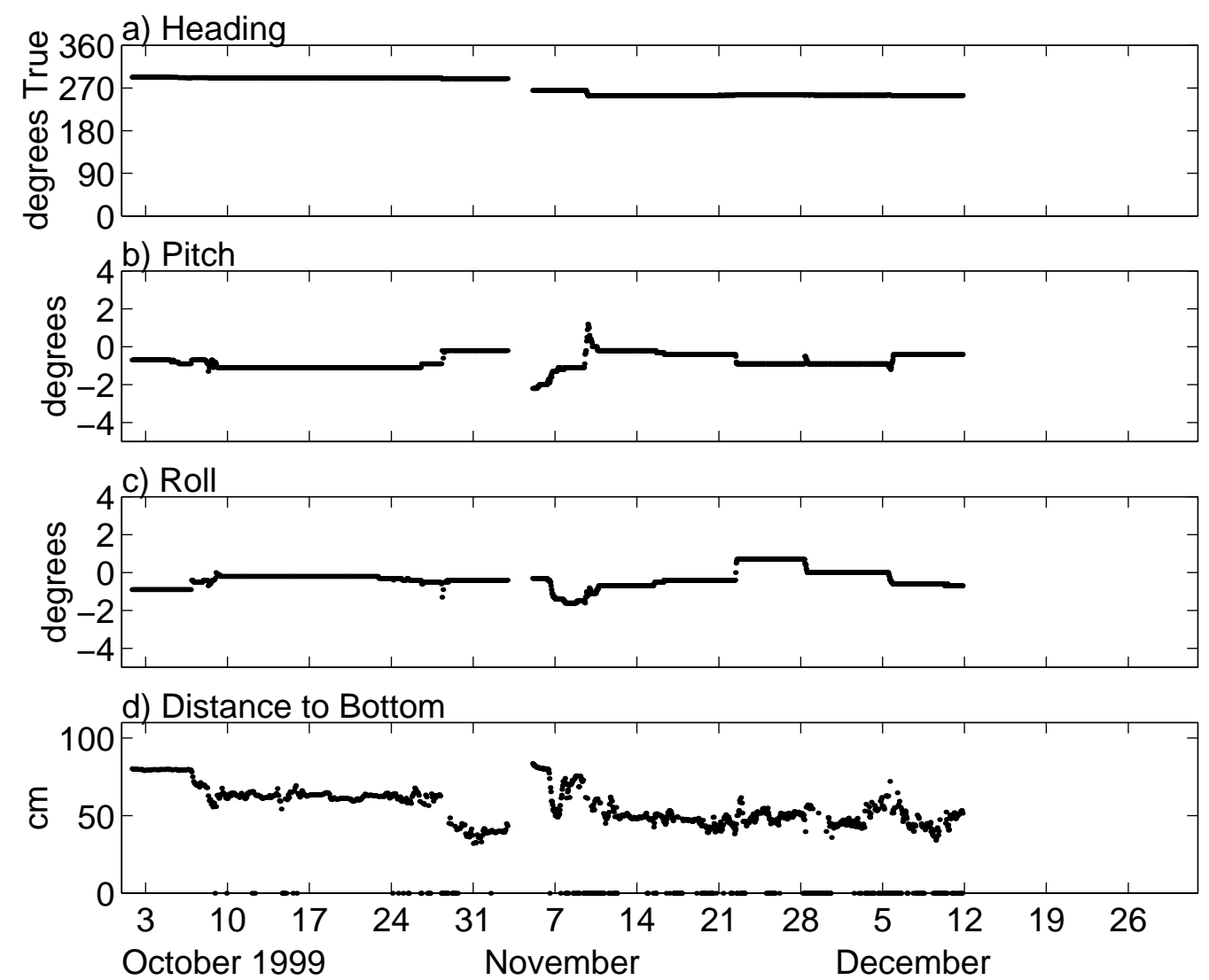

Figure 18. Time series of heading, pitch, roll, and distance to the bottom from data collected by the ADV at Site ND. 

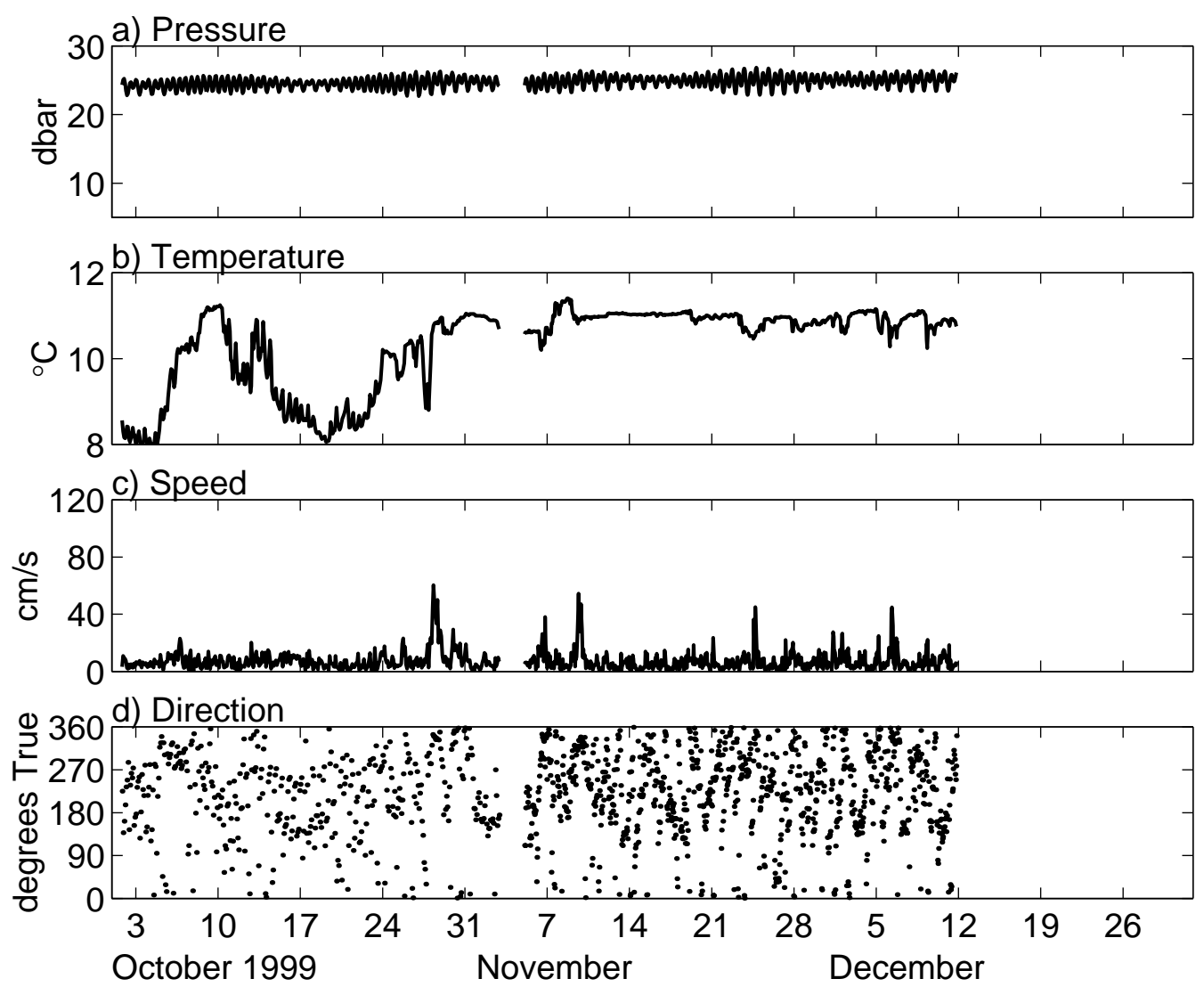

Figure 19. Time series of pressure, temperature, speed, and direction from data collected by the ADV at Site ND. 

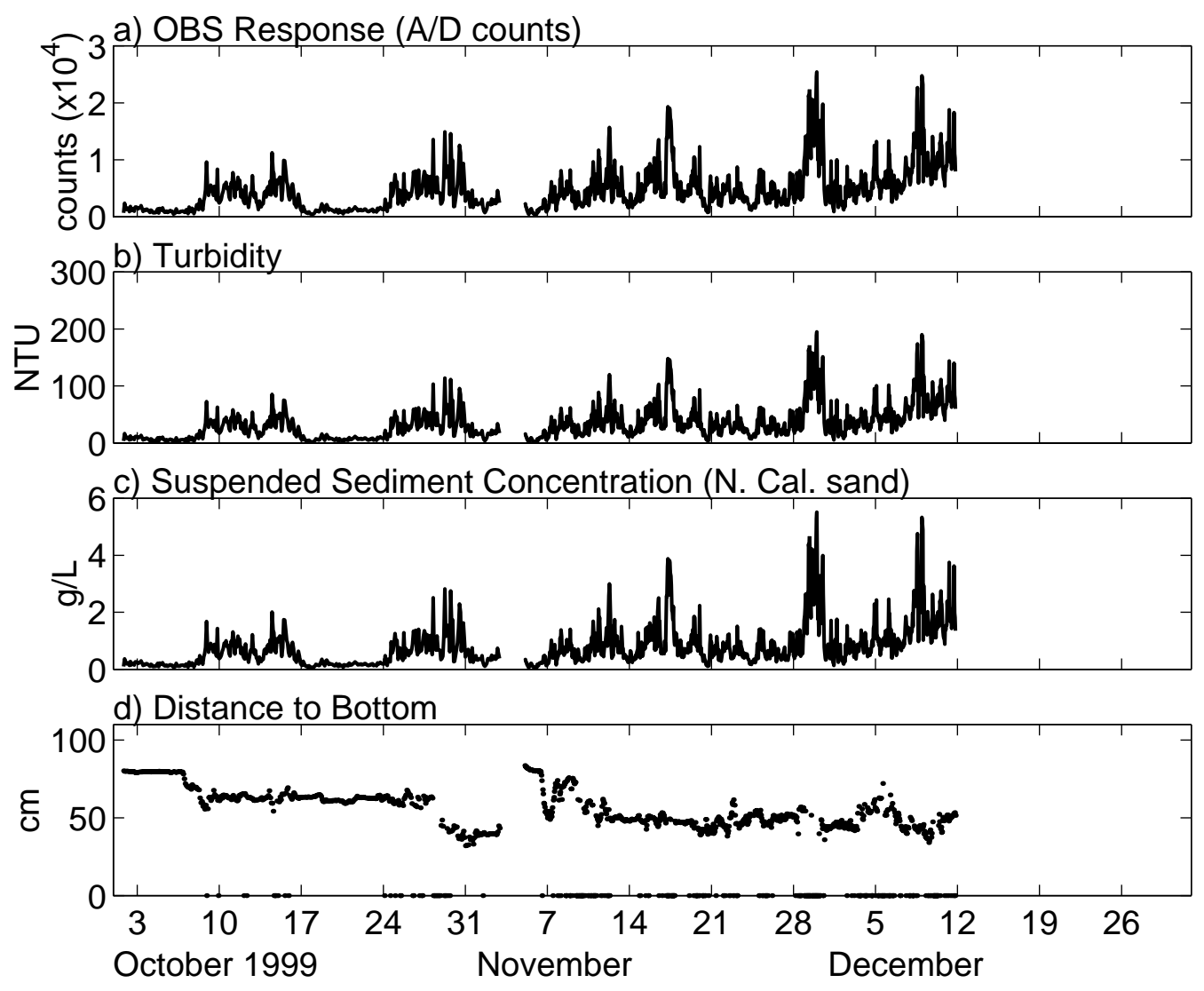

Figure 20. Time series of the response of the OBS, turbidity, suspended sediment concentration, and distance to the bottom for Site ND. 

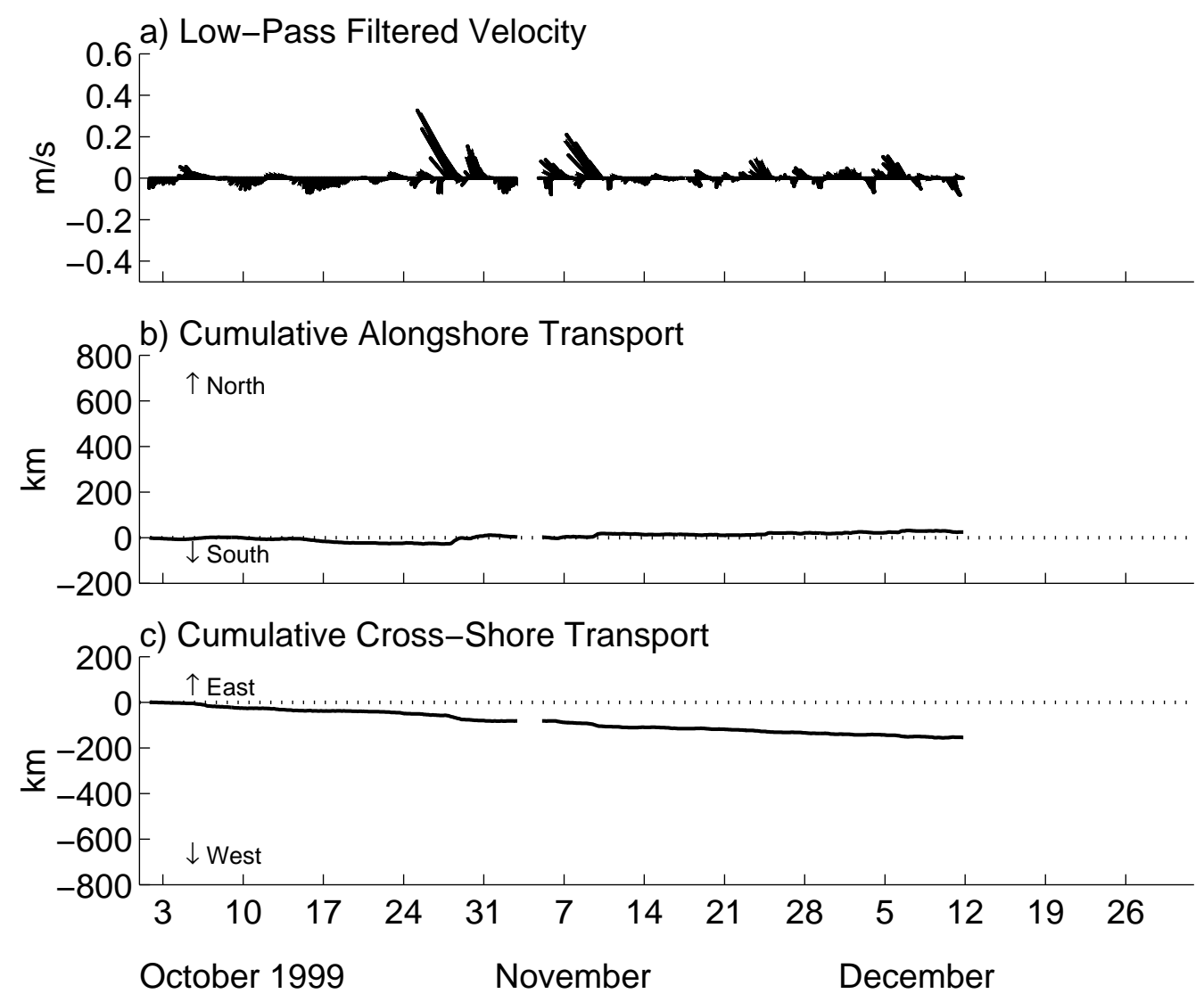

Figure 21. Time series of low-pass filtered velocity and cumulative alongshore and cross-shore transport for Site ND. 

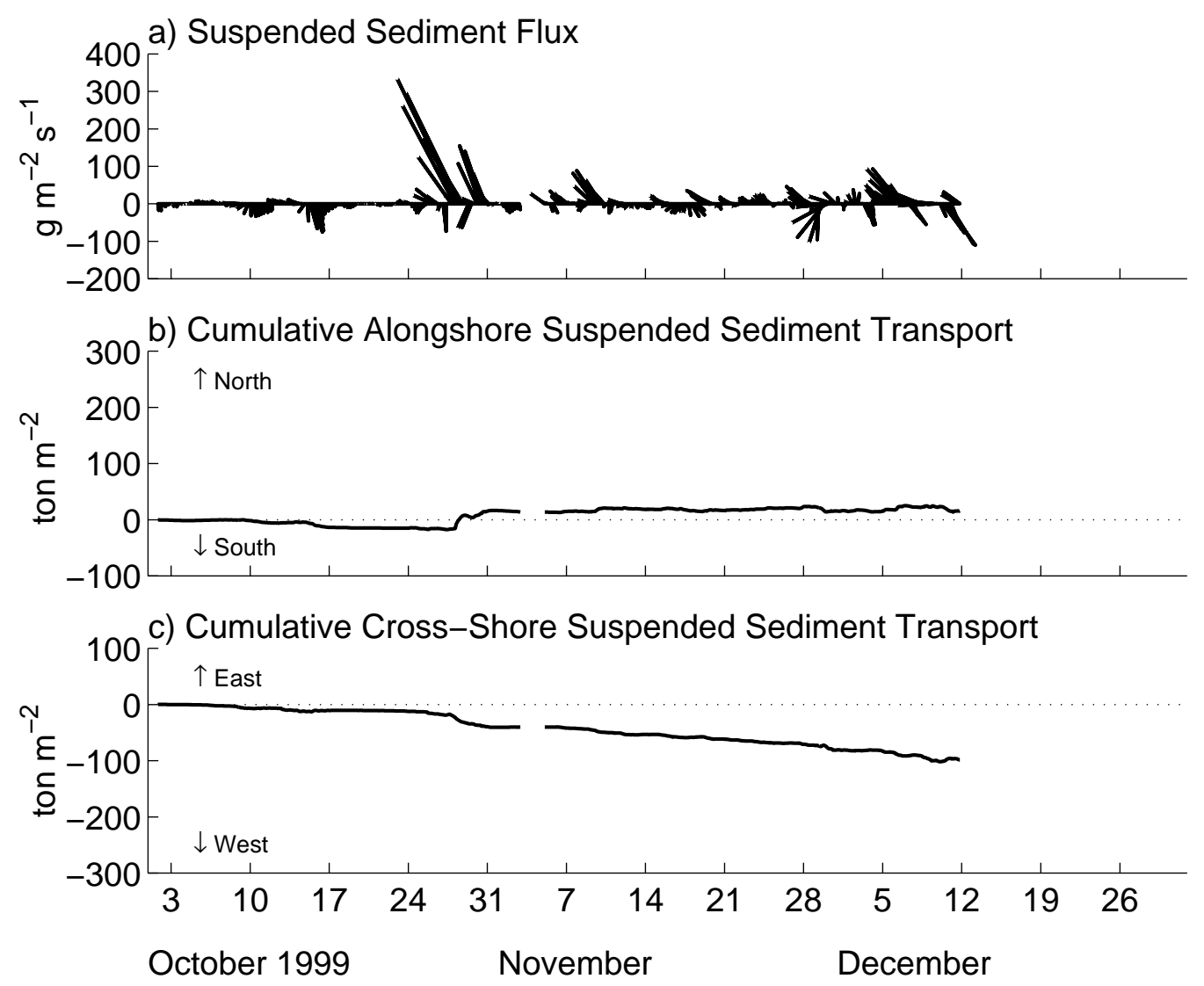

Figure 22. Time series of suspended sediment flux and cumulative alongshore and cross-shore suspended sediment transport for Site ND. 

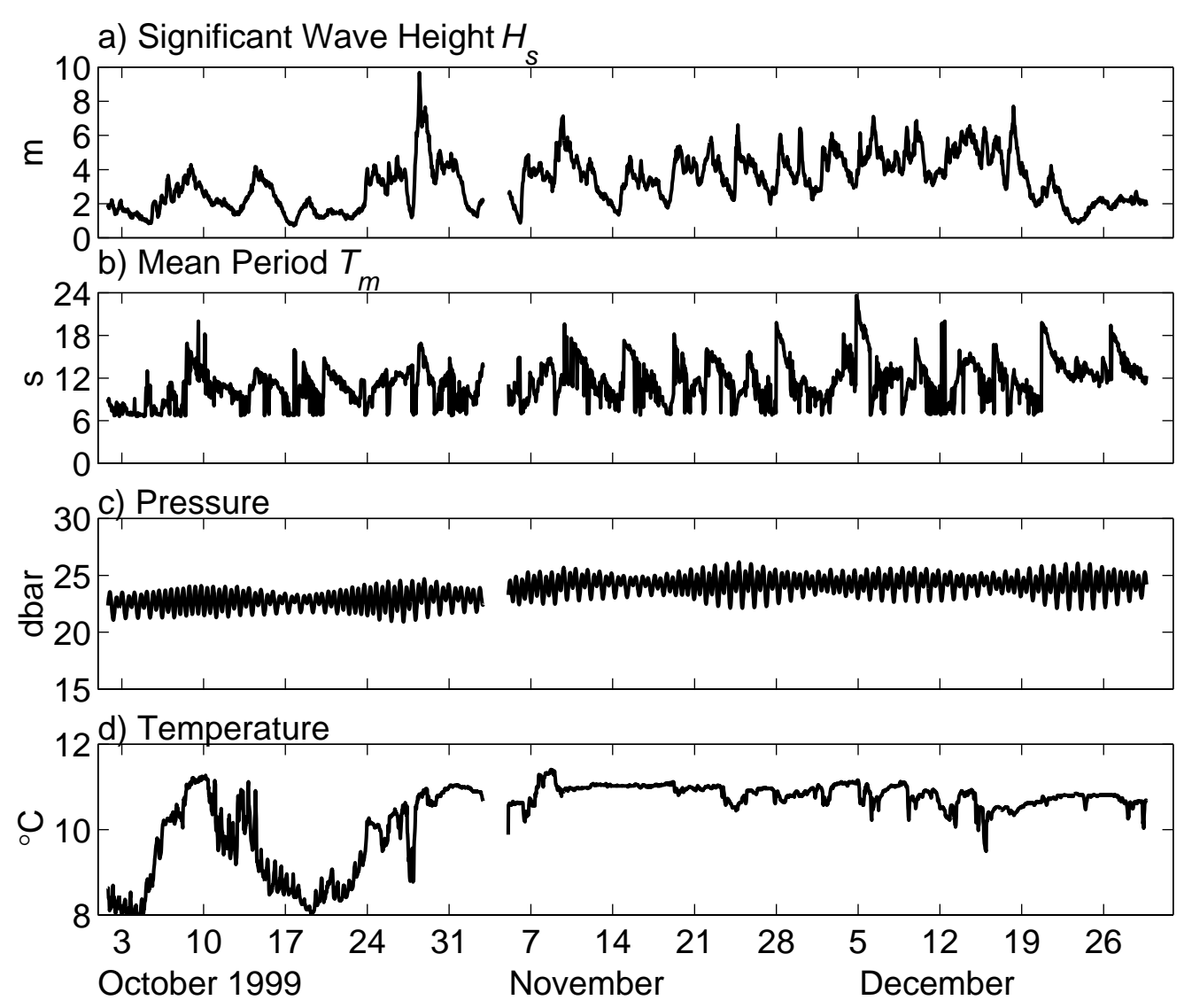

Figure 23. Time series of significant wave height, mean period, pressure, and temperature from data collected by the ADP at Site ND. 

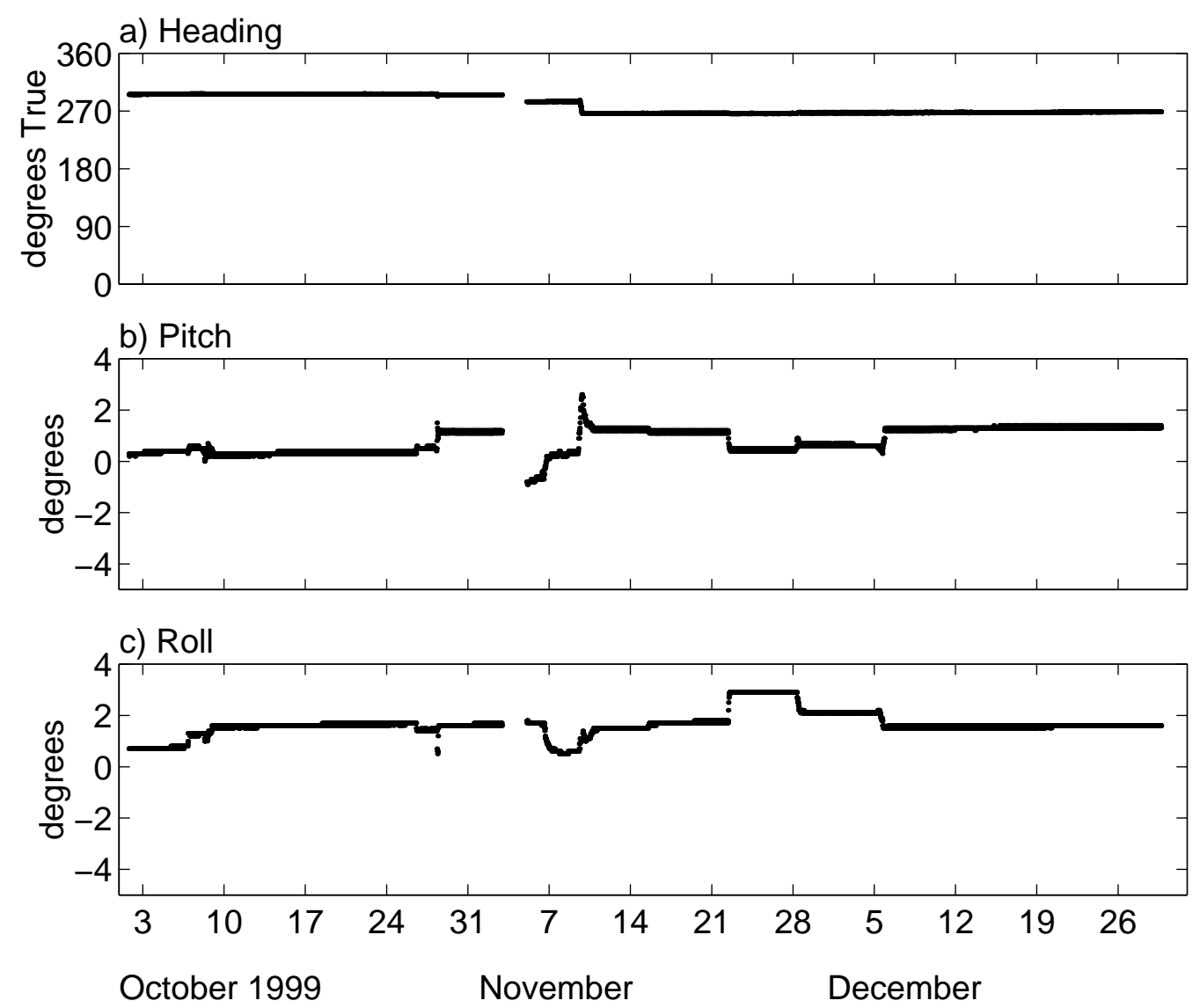

Figure 24. Time series of heading, pitch, and roll from data collected by the ADP at Site ND. 


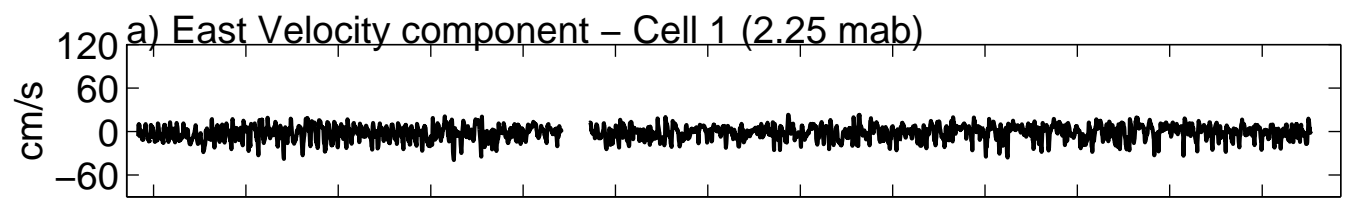

120 b) North Velocity Component - Cell 1 (2.25 mab)
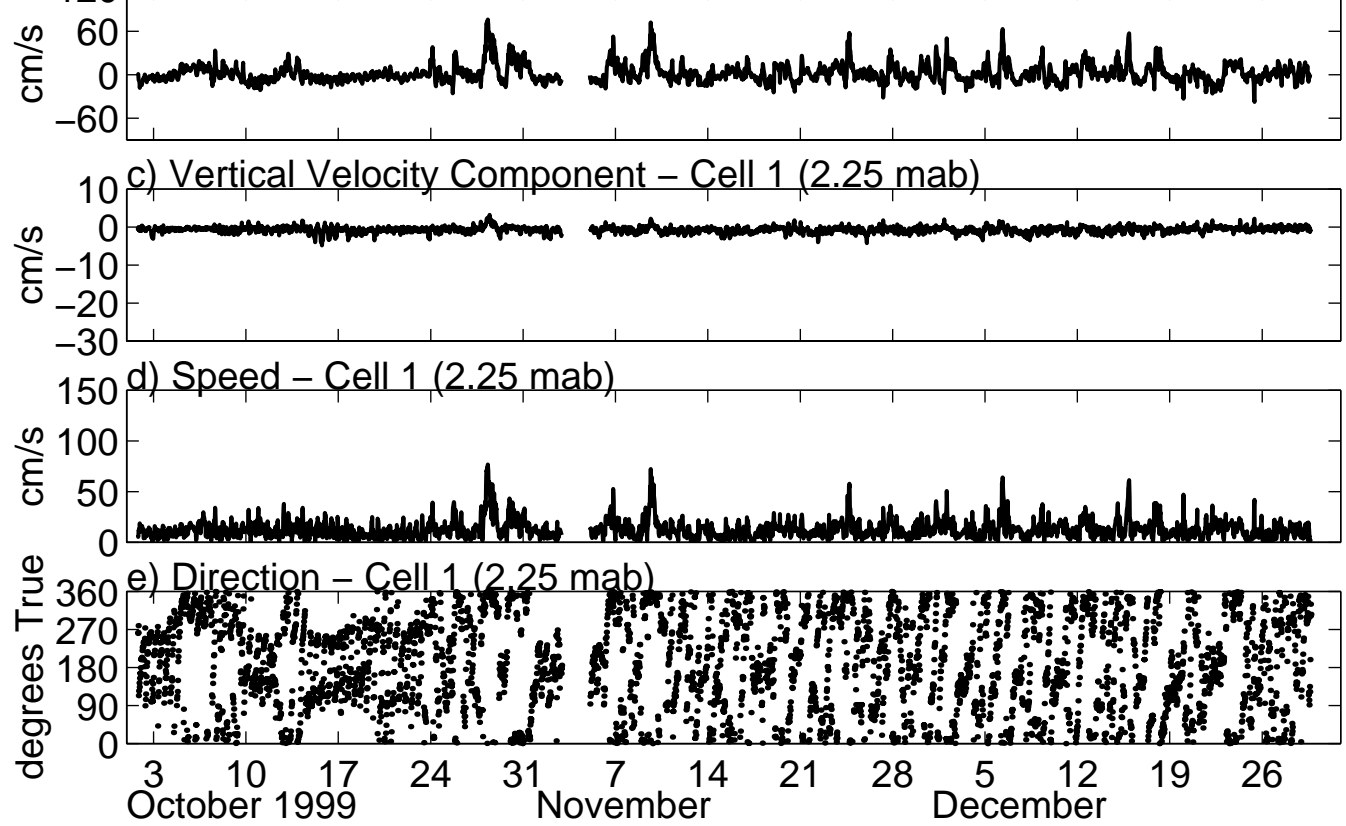

Figure 25. Time series of east (positive eastward), north (positive northward), and vertical (positive up) velocity components, speed, and direction in cell 1 (2.25 mab) from data collected by the ADP at Site ND. 

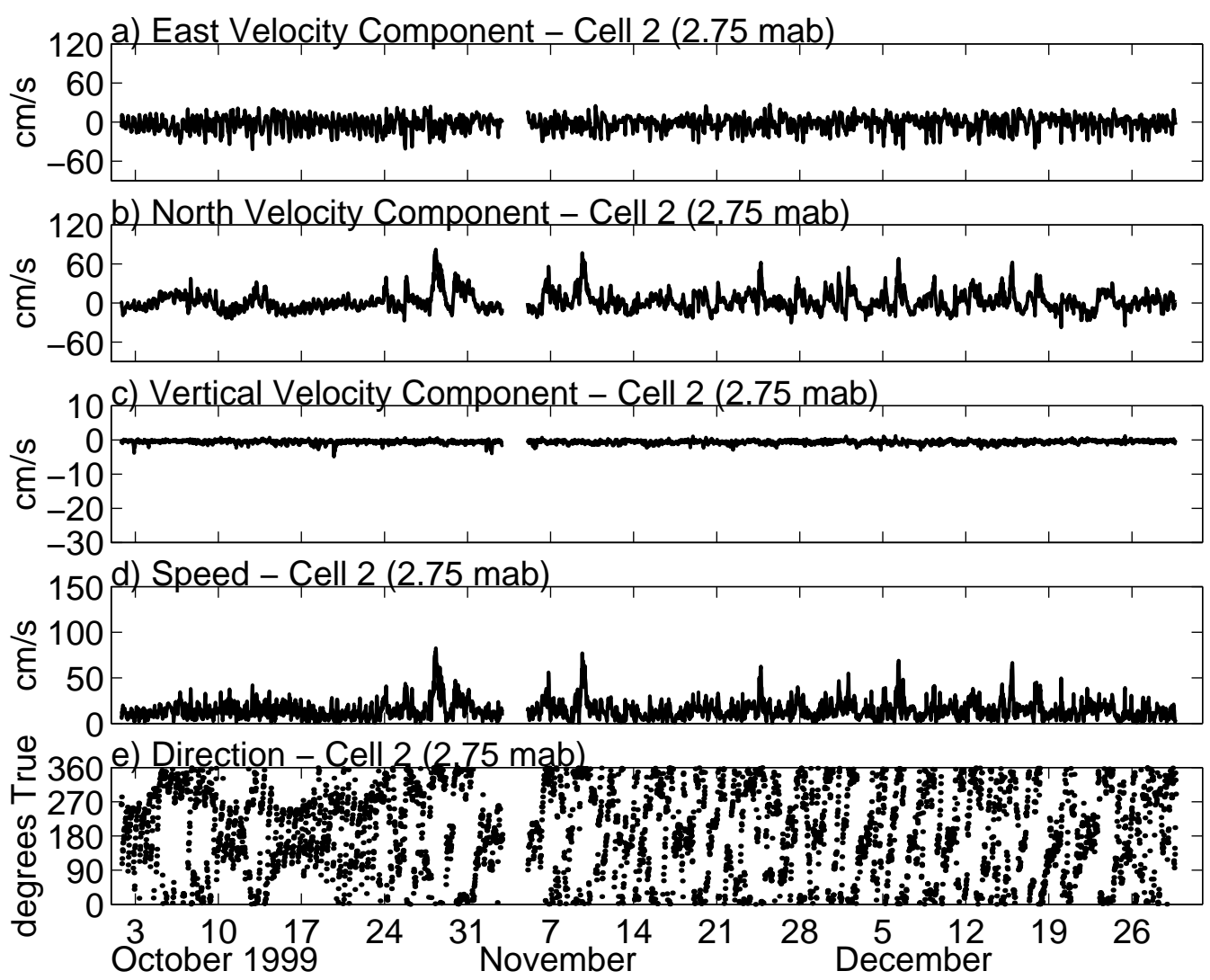

Figure 26. Time series of east (positive eastward), north (positive northward), and vertical (positive up) velocity components, speed, and direction in cell 2 (2.75 mab) from data collected by the ADP at Site ND. 

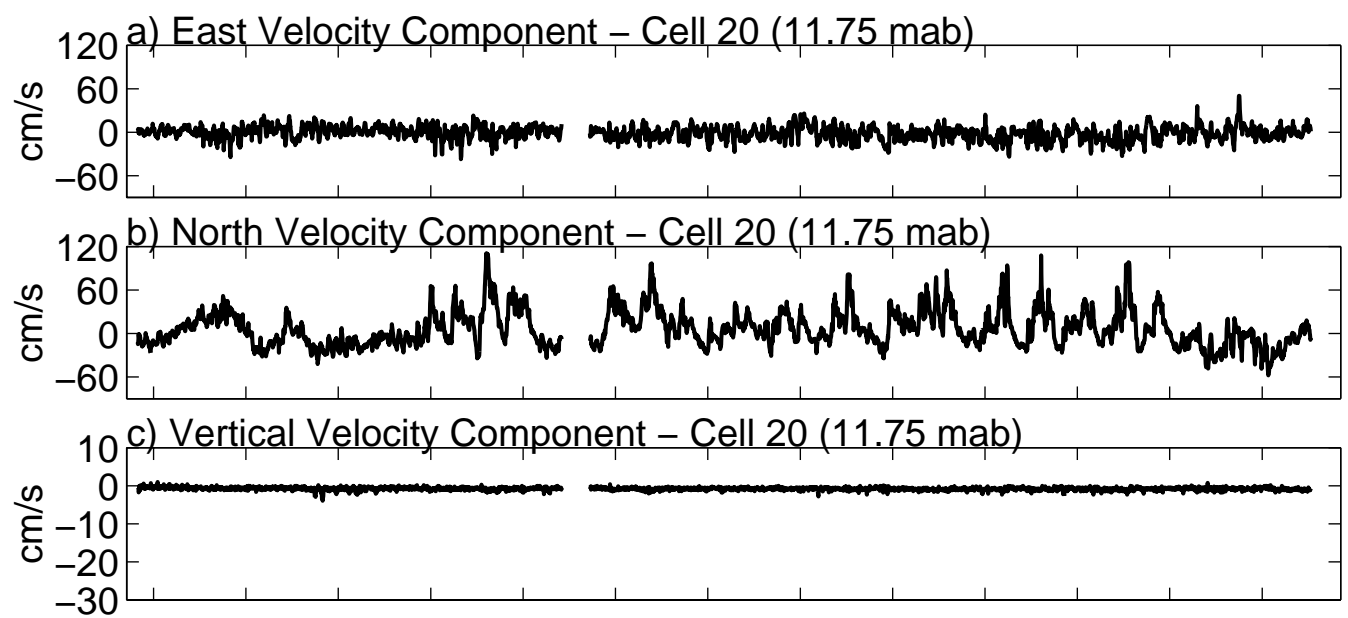

150 d) Speed - Cell 20 (11.75 mab)
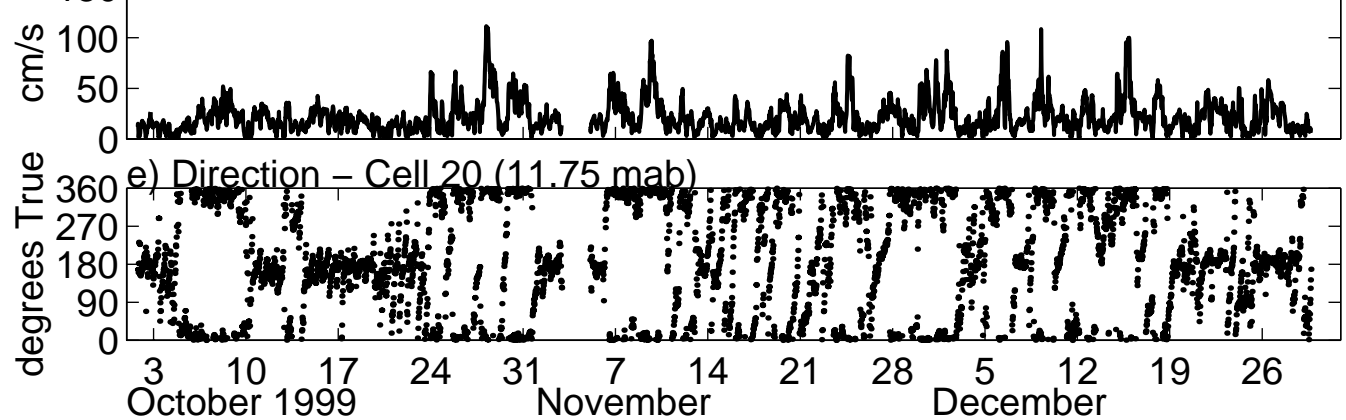

Figure 27. Time series of east (positive eastward), north (positive northward), and vertical (positive up) velocity components, speed, and direction in cell 20 (11.75 mab) from data collected by the ADP at Site ND. 

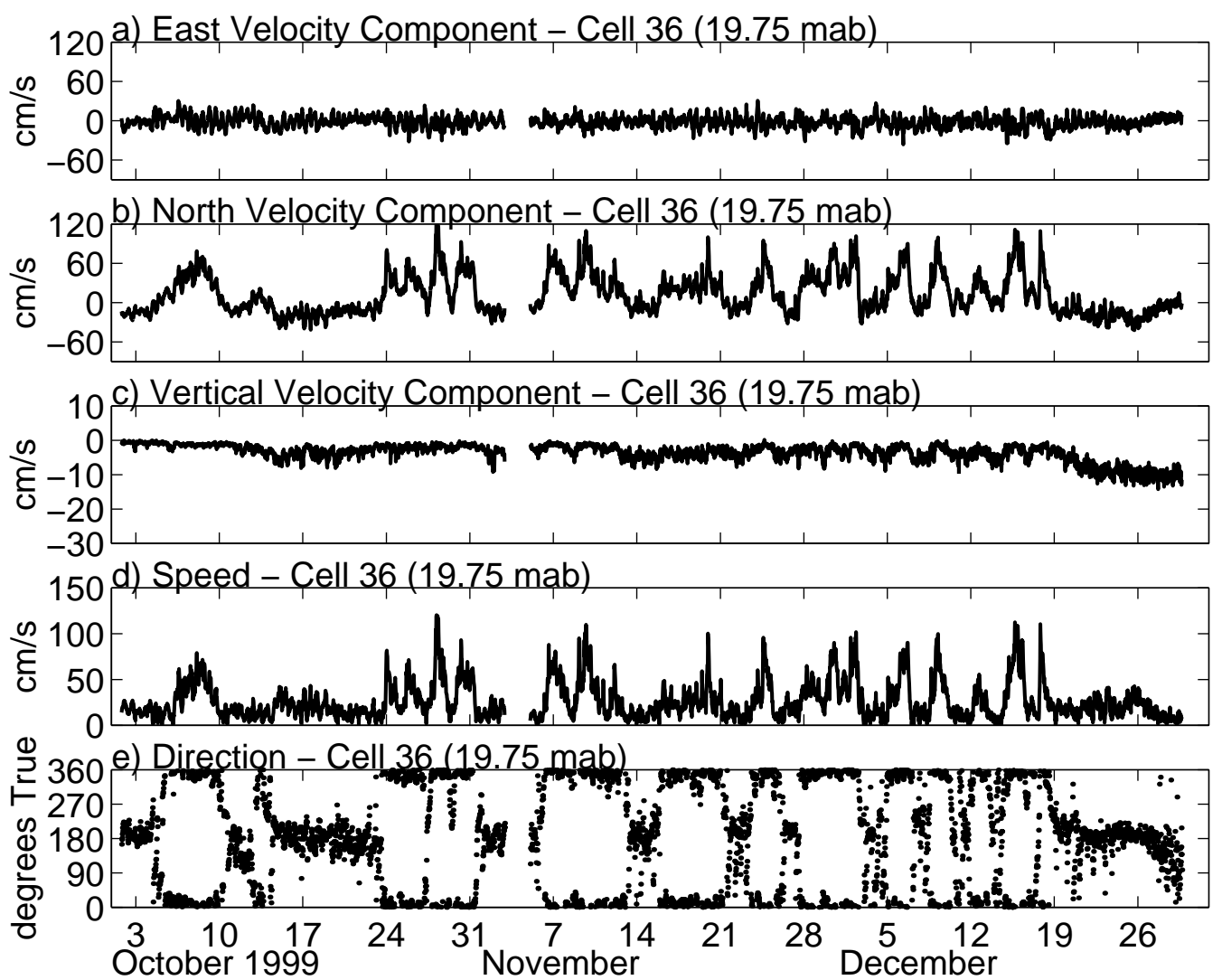

Figure 28. Time series of east (positive eastward), north (positive northward), and vertical (positive up) velocity components, speed, and direction in cell 36 (19.75 mab) from data collected by the ADP at Site ND. 

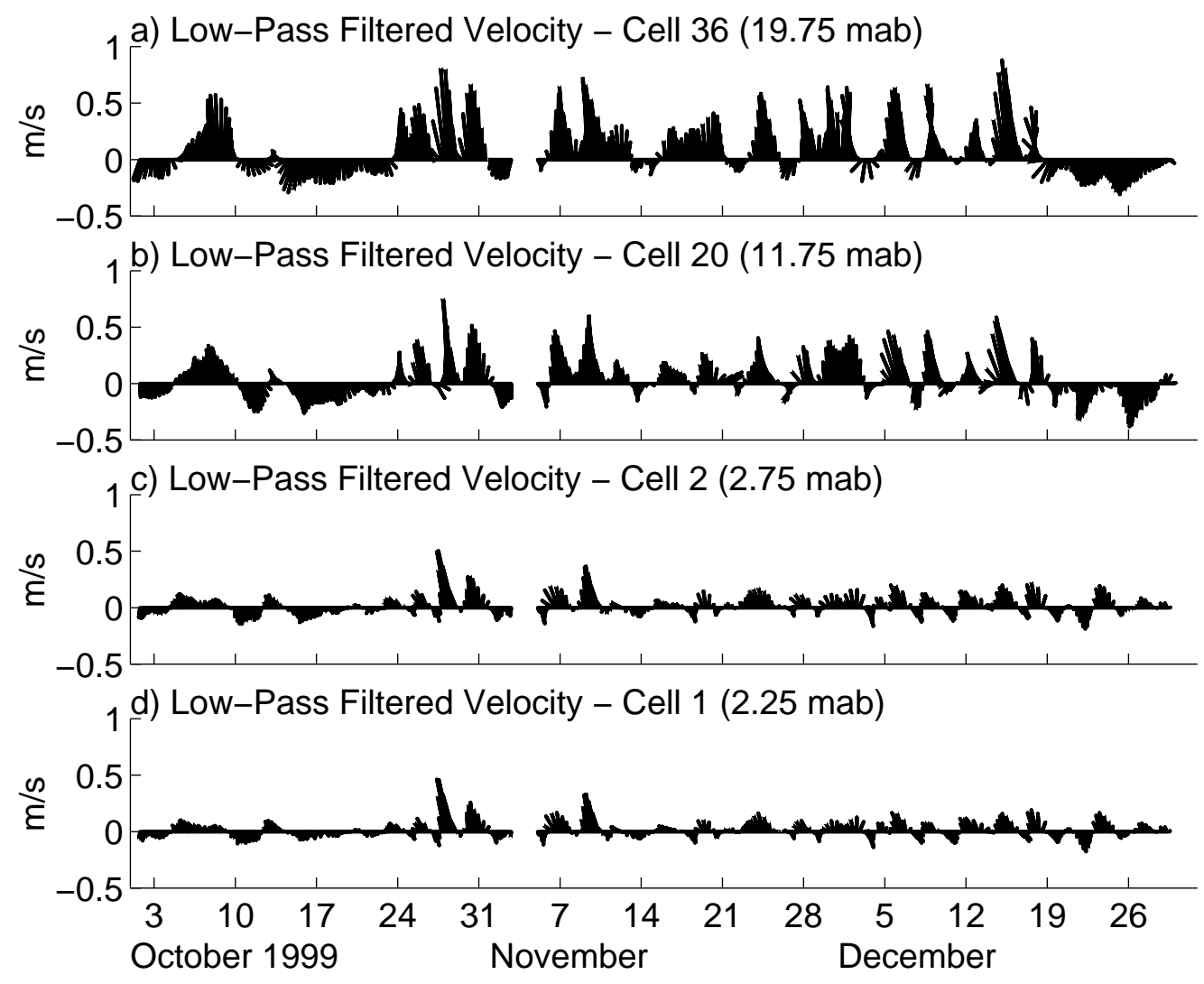

Figure 29. Time series of low-pass filtered velocity for several ADP cells at Site ND. 

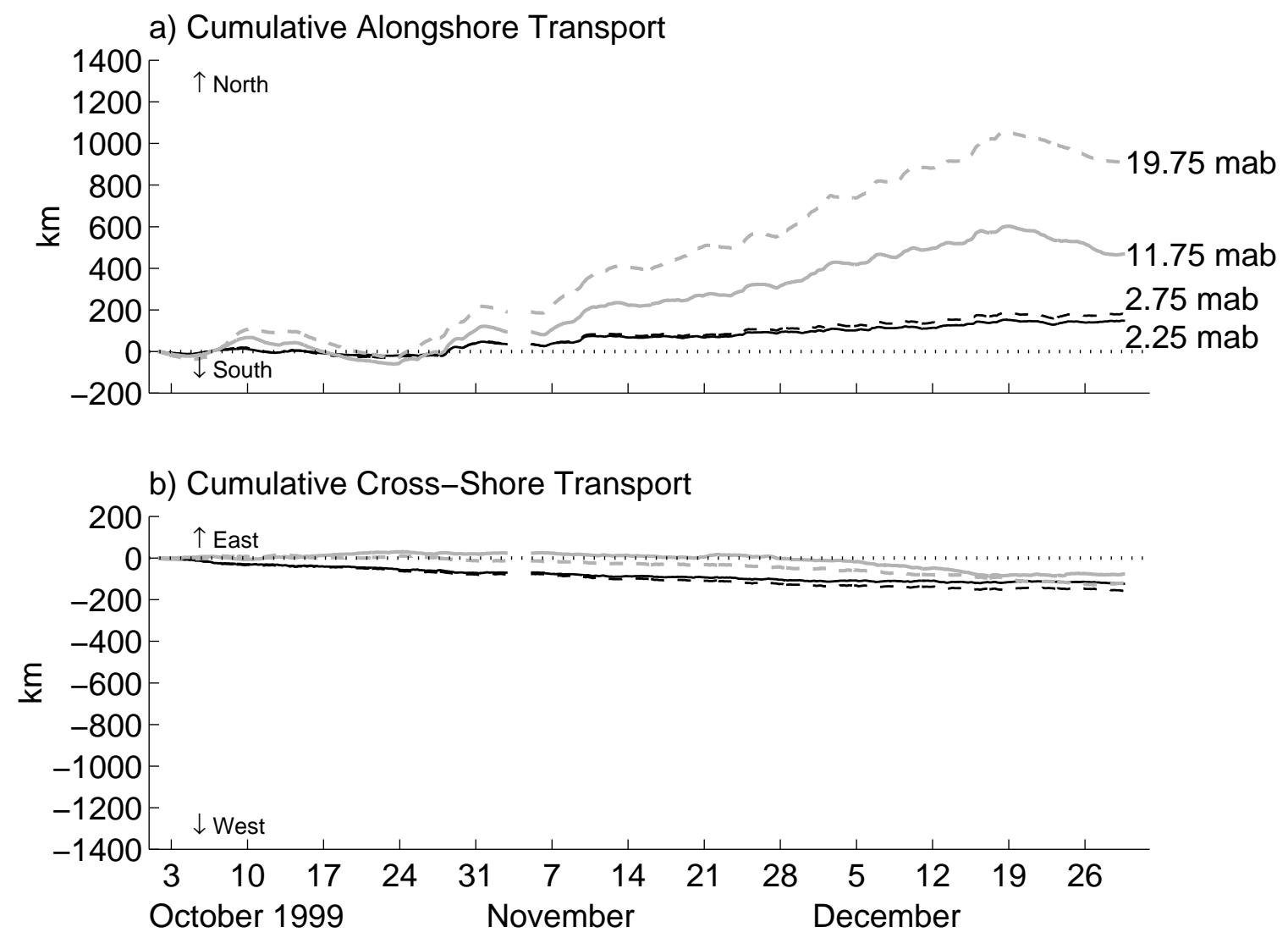

Figure 30. Time series of cumulative alongshore and cross-shore transport for several ADP cells at Site ND 


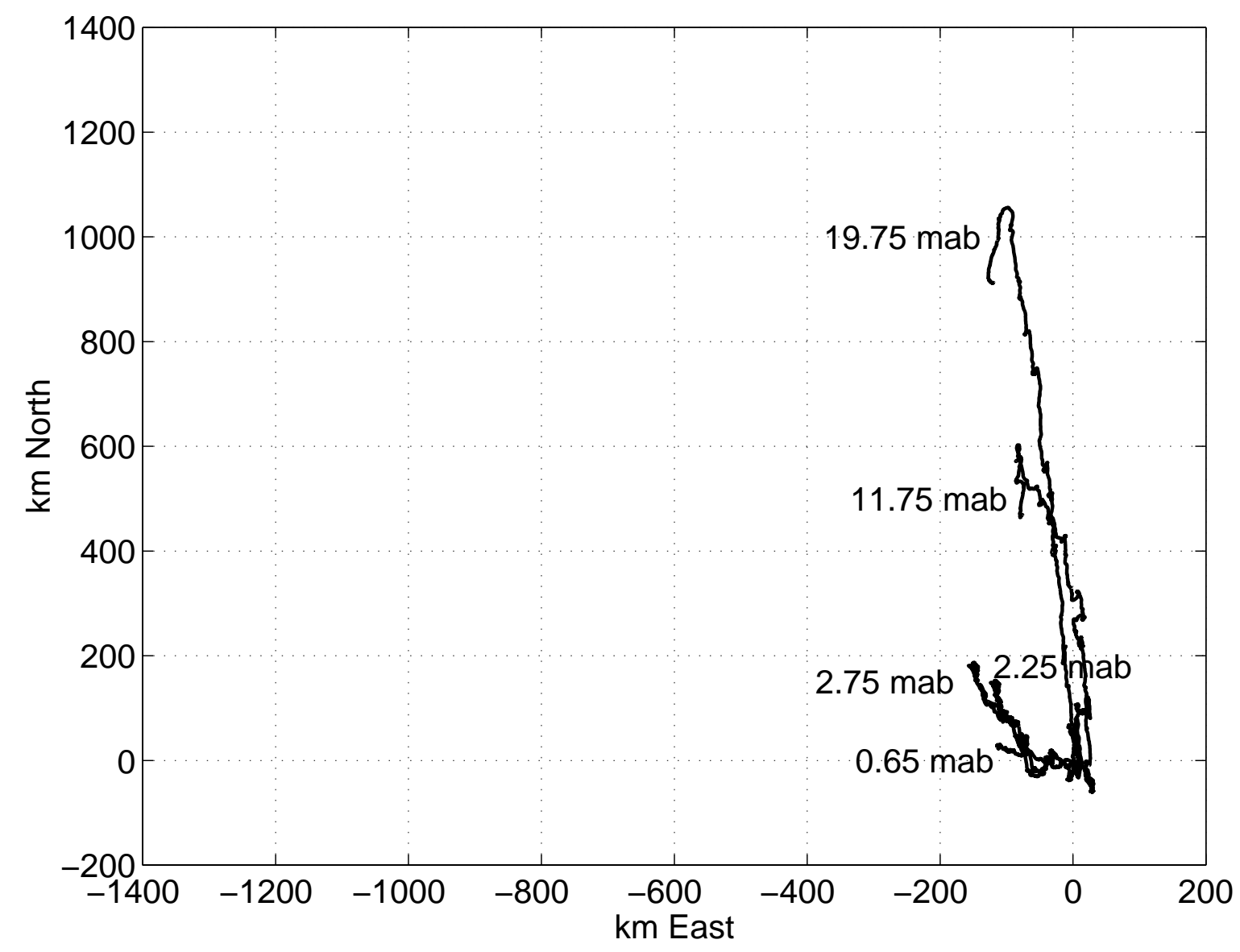

Figure 31. Progressive vector diagram of currents at Site ND.Measurement period for the ADP (elevations 2.25 to $19.75 \mathrm{mab}$ ) was 10/01/99-11/02/99 and 11/05/99-12/29/99. Measurement period for the ADV (0.65 mab) was 10/01/99-11/02/99 and 11/05/99-12/11/99. 


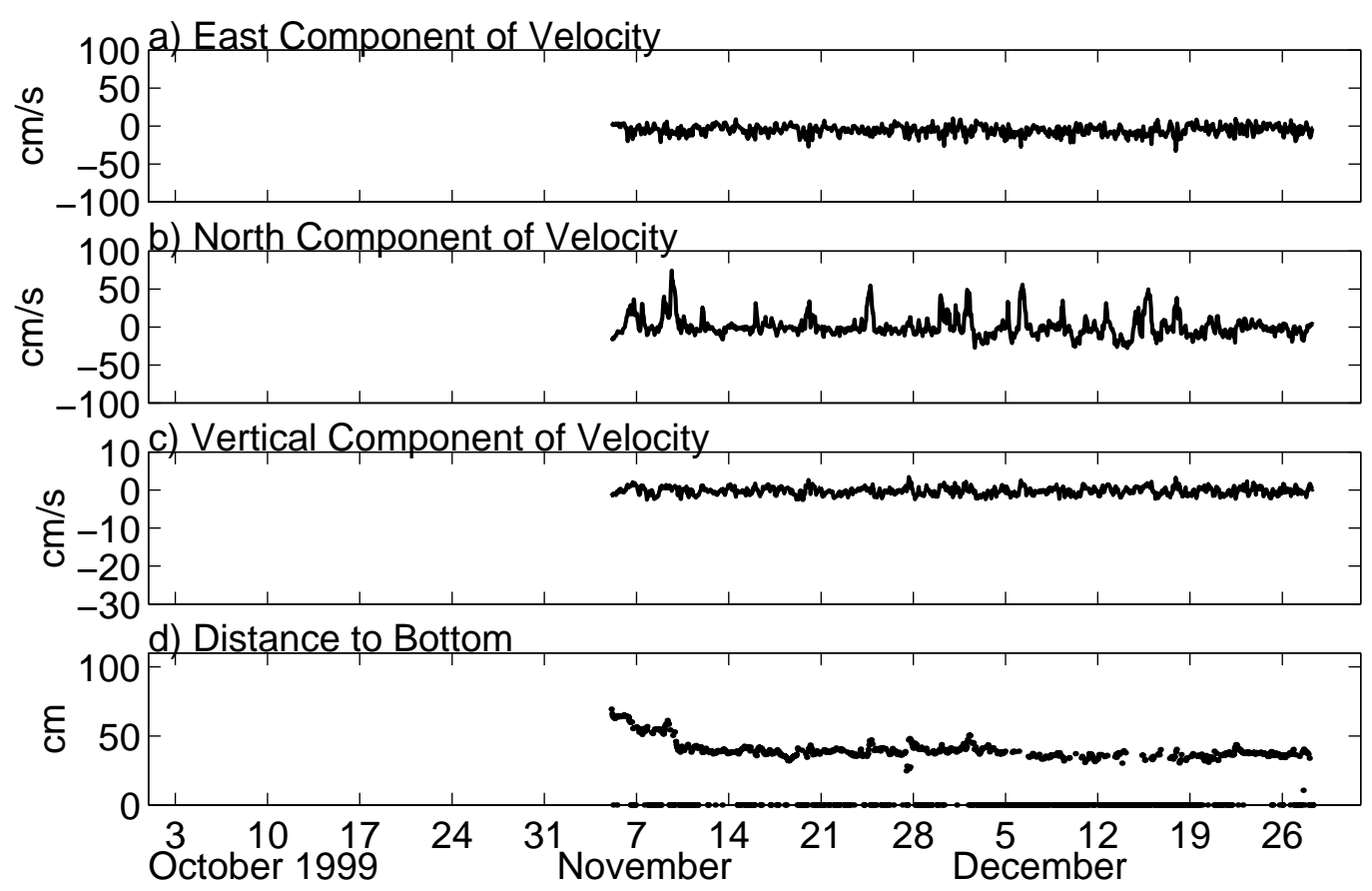

Figure 32. Time series of east (positive eastward), north (positive northward), and vertical (positive up) velocity components, turbidity, and distance to the bottom from data collected by the ADV at Site NS. 

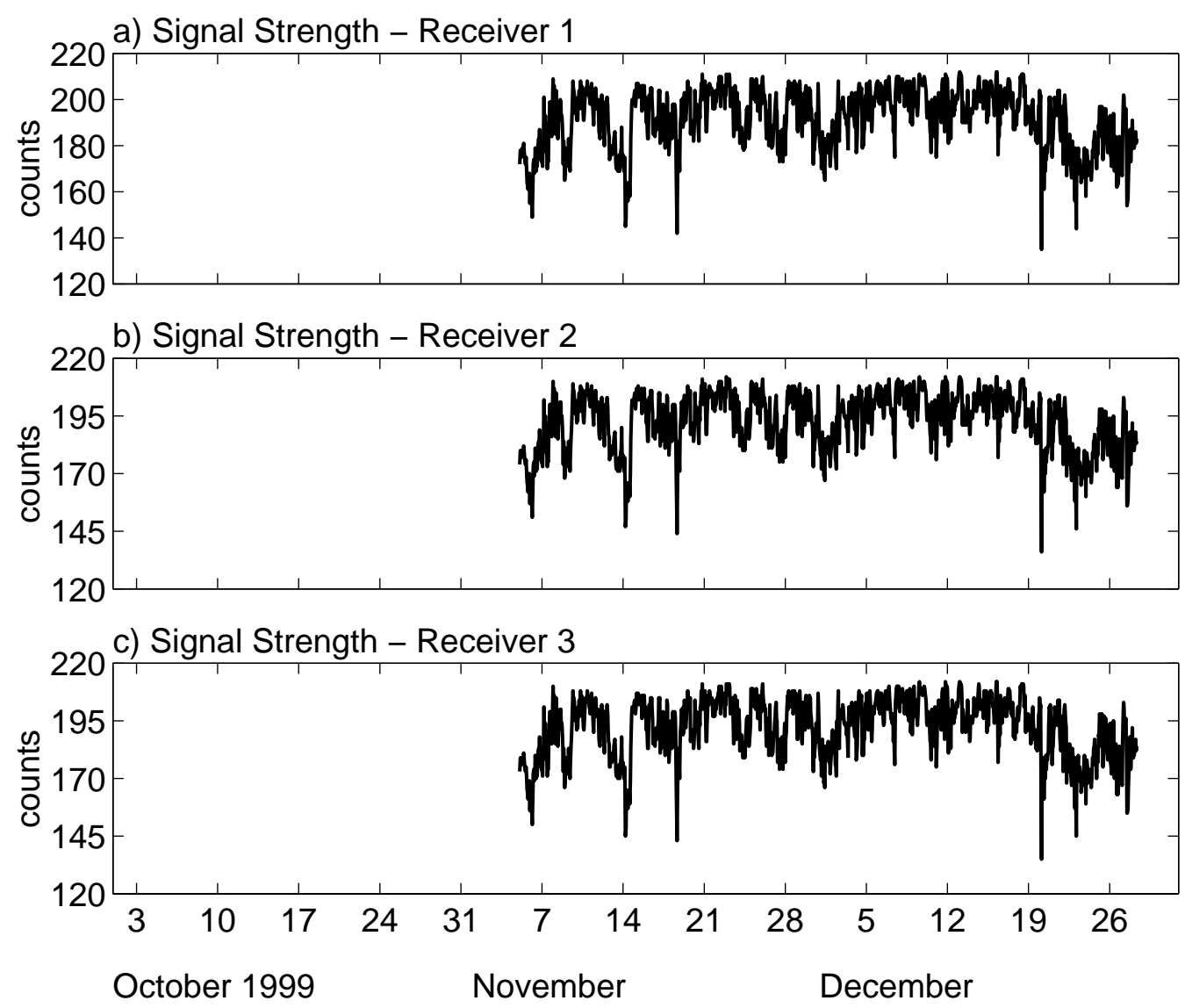

Figure 33. Time series of signal strength collected for each ADV receiver at Site NS. 

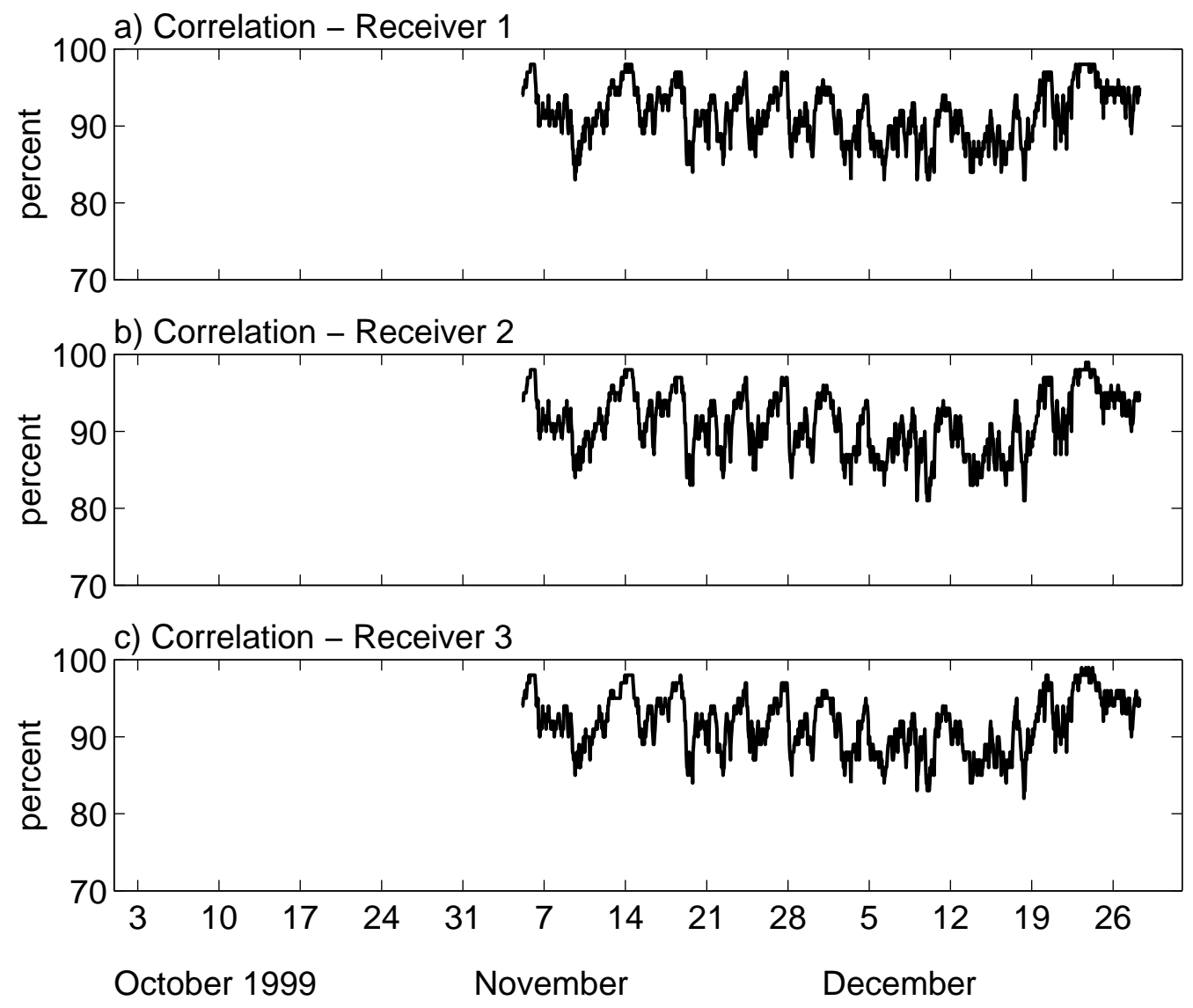

Figure 34. Time series of signal correlation for ADV receivers at Site NS. 

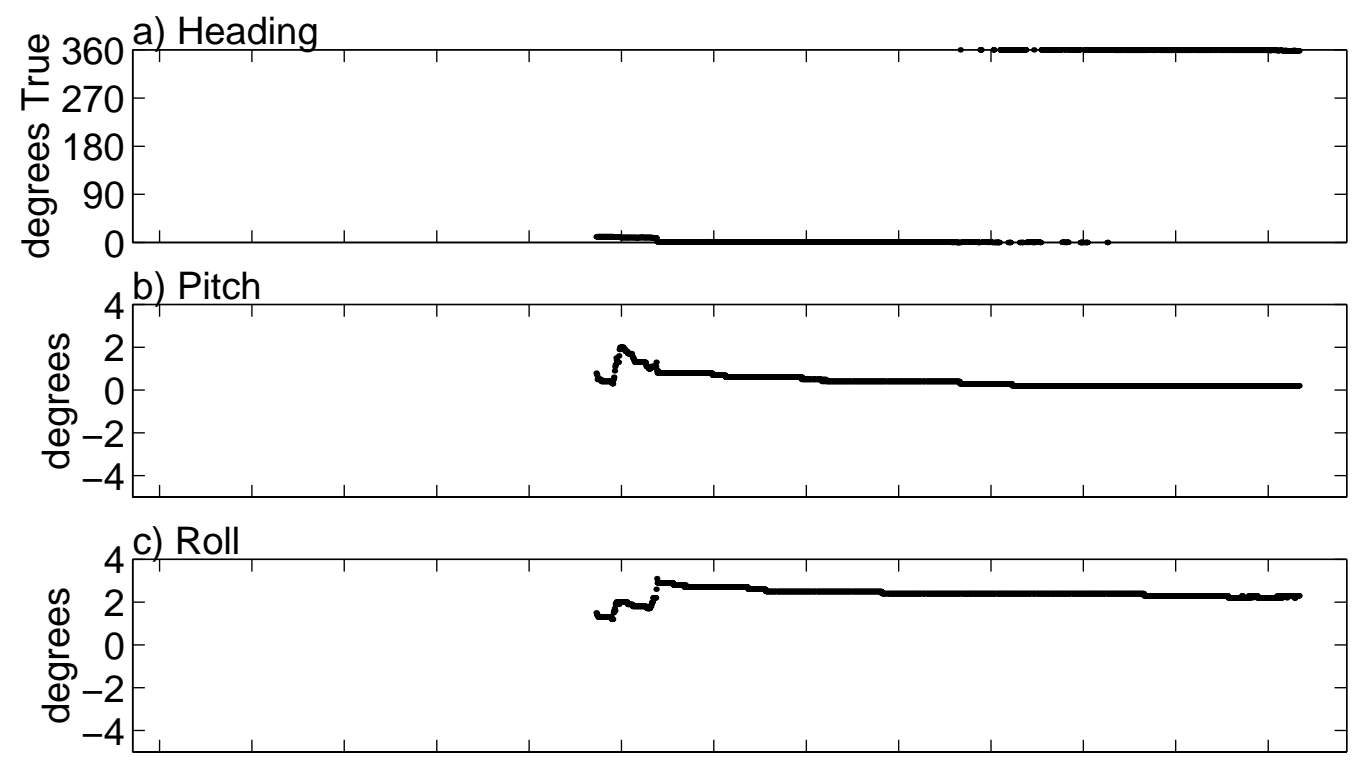

d) Distance to Bottom

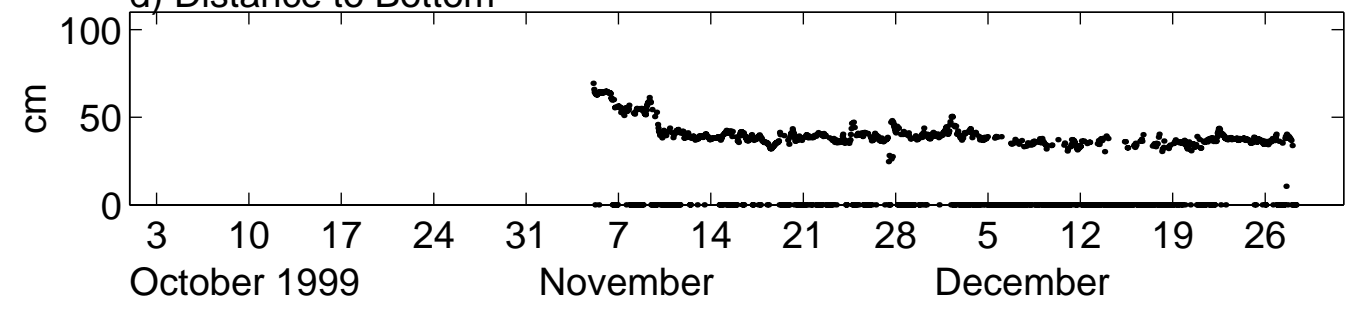

Figure 35. Time series of heading, pitch, roll, and distance to the bottom from data collected by the ADV at Site NS. 

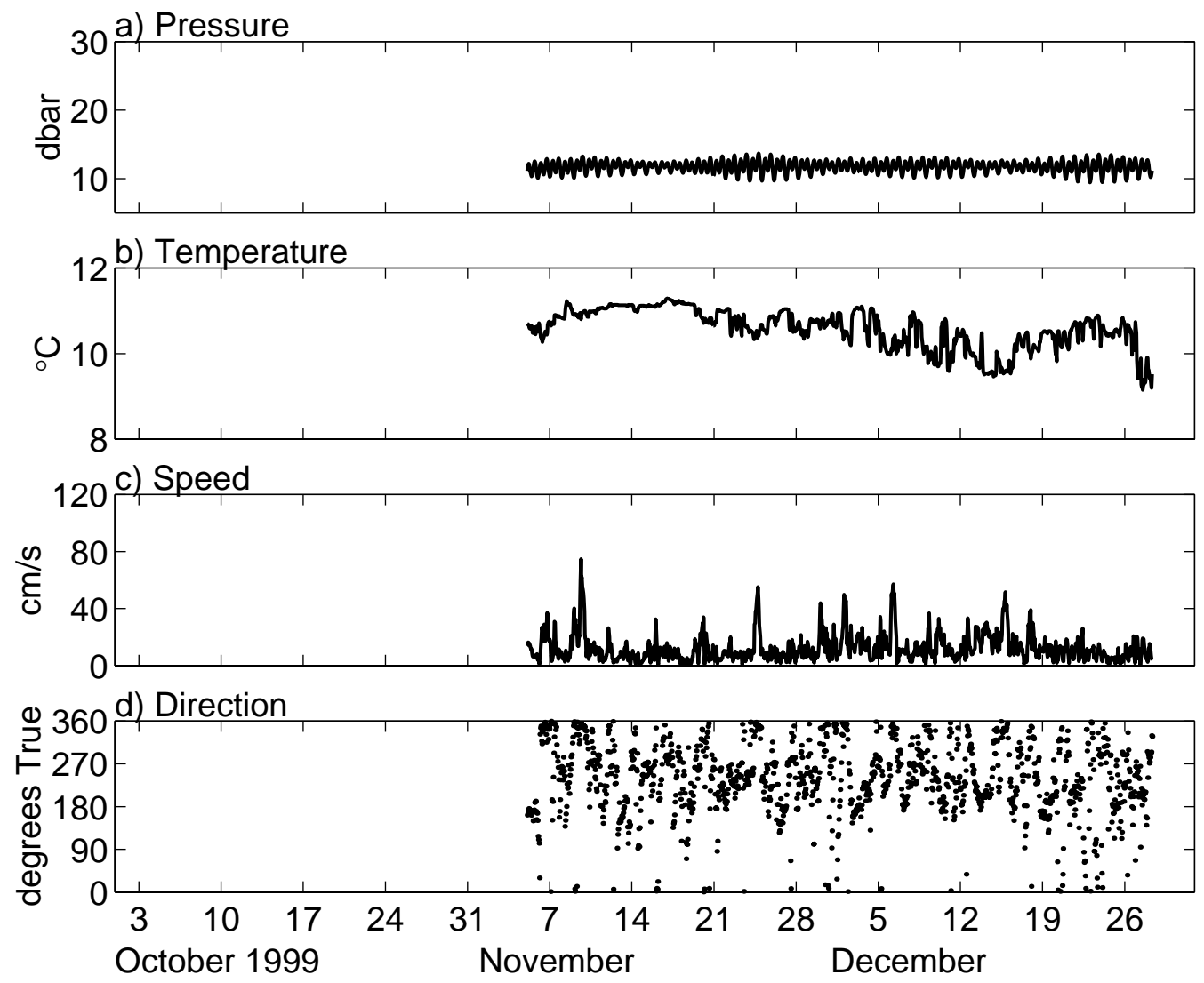

Figure 36. Time series of pressure, temperature, speed, and direction from data collected by the ADV at Site NS. 

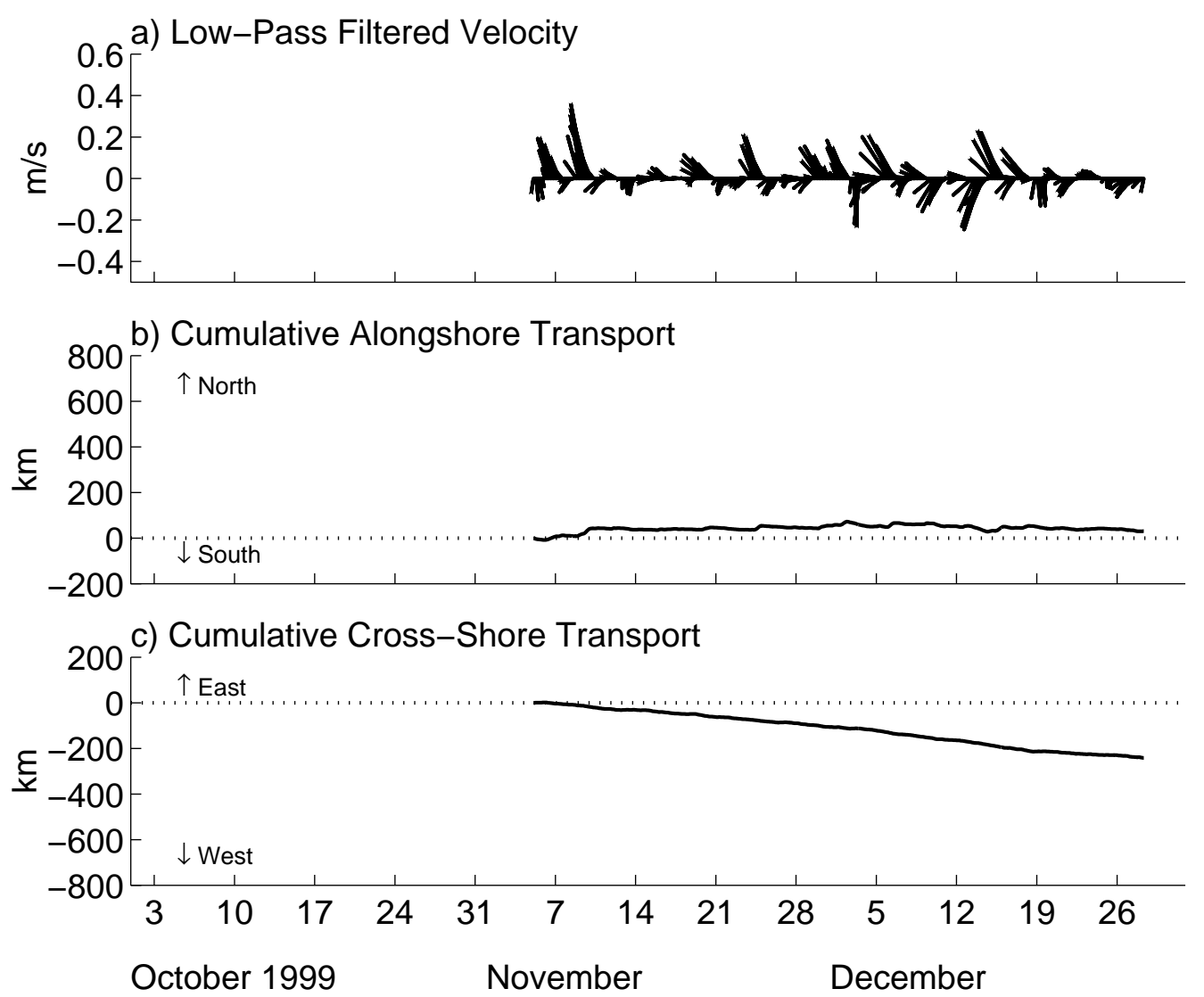

Figure 37. Time series of low-pass filtered velocity and cumulative alongshore and cross-shore transport for Site NS. 


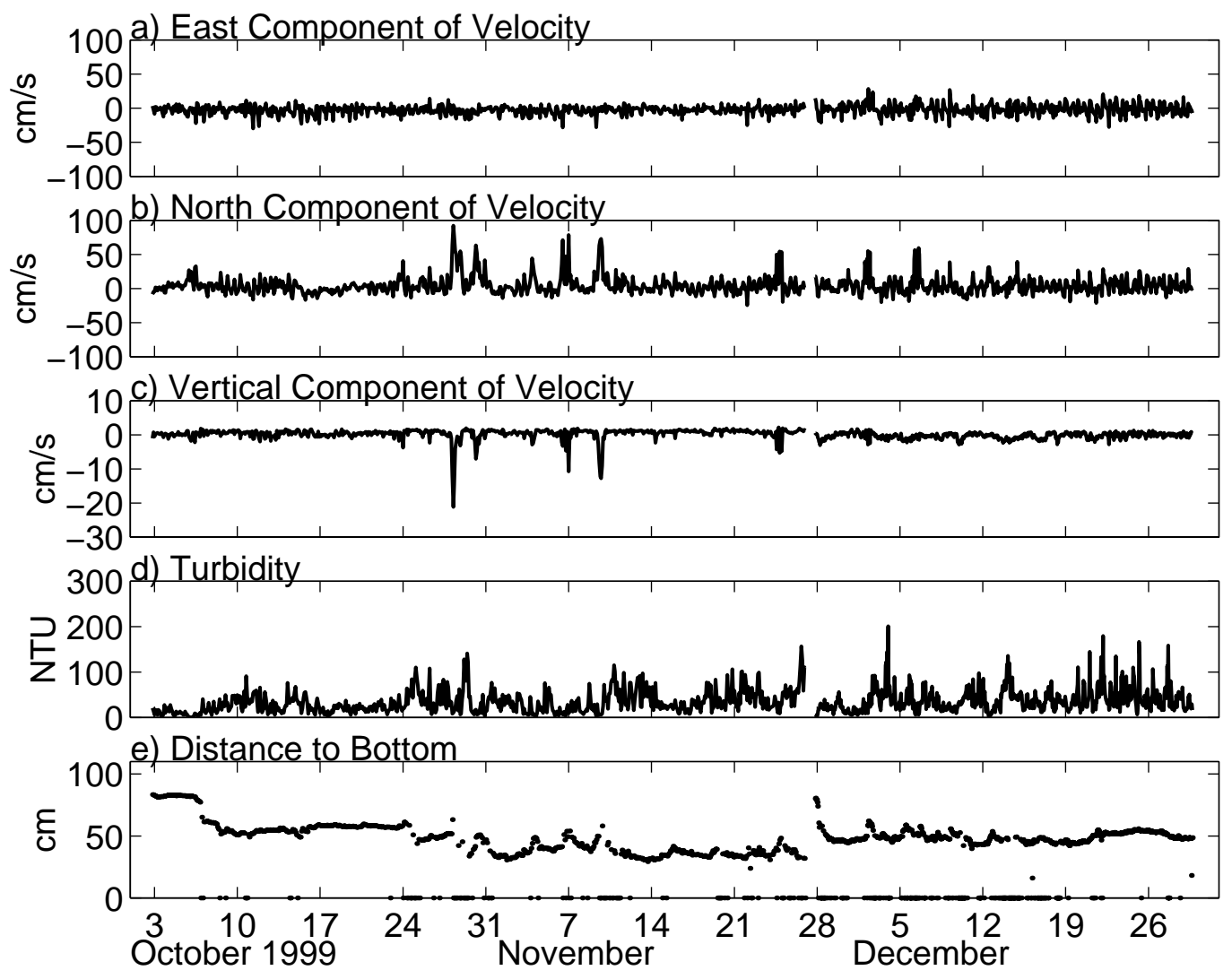

Figure 38. Time series of east (positive eastward), north (positive northward), and vertical (positive up) velocity components, turbidity, and distance to the bottom from data collected by the ADV at Site MD. 

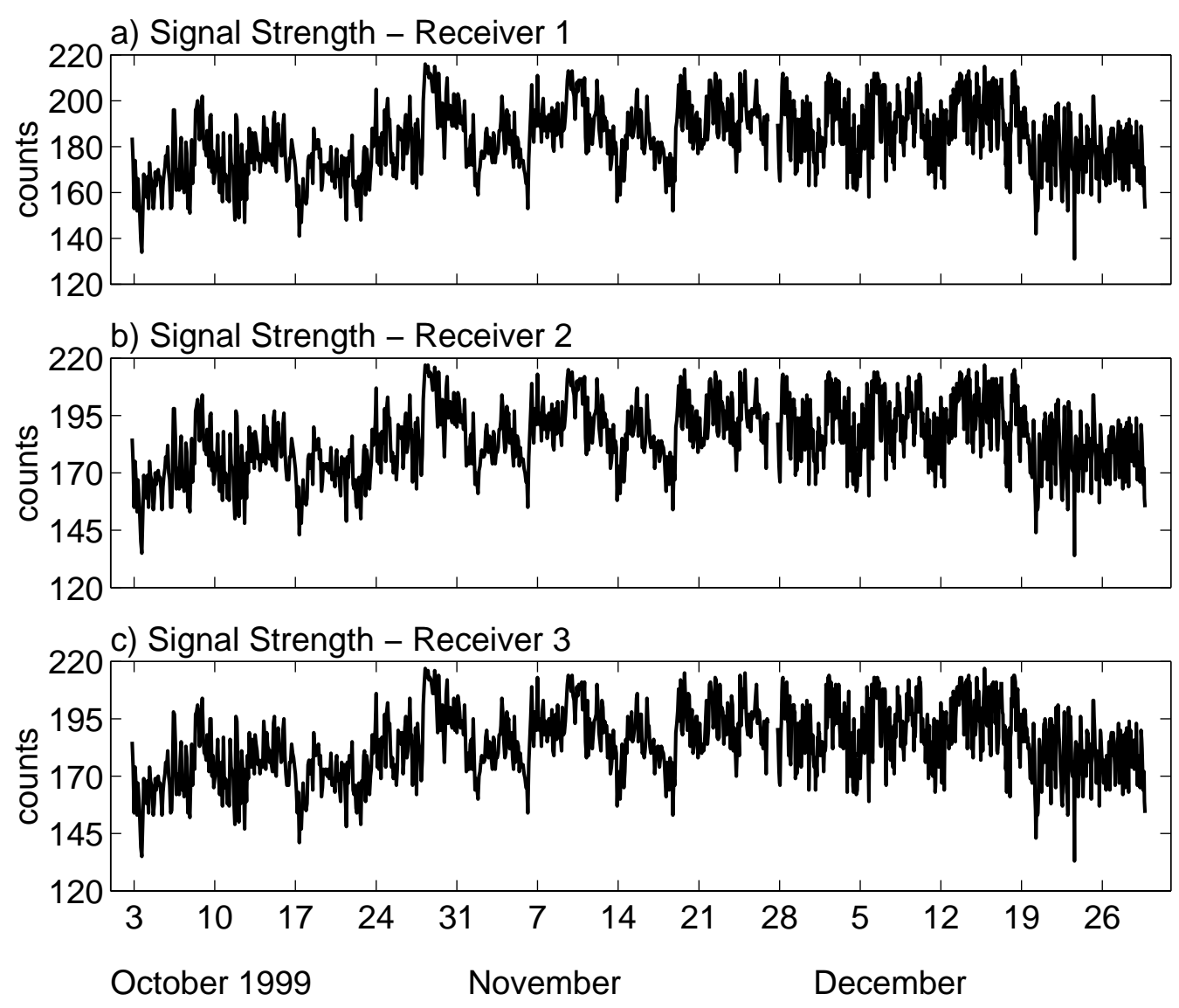

Figure 39. Time series of signal strength collected for each ADV receiver at Site MD. 

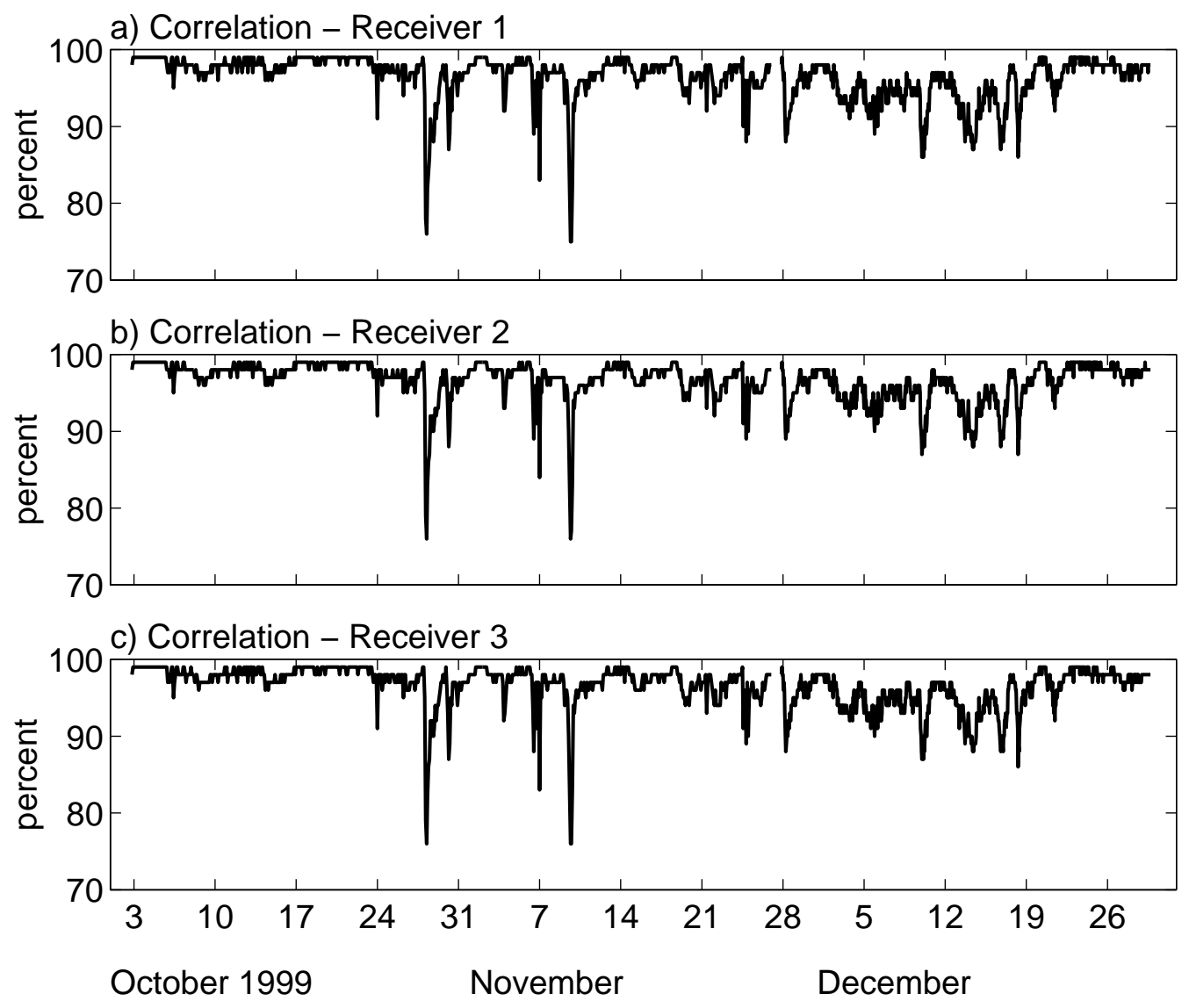

Figure 40. Time series of signal correlation for ADV receivers at Site MD. 

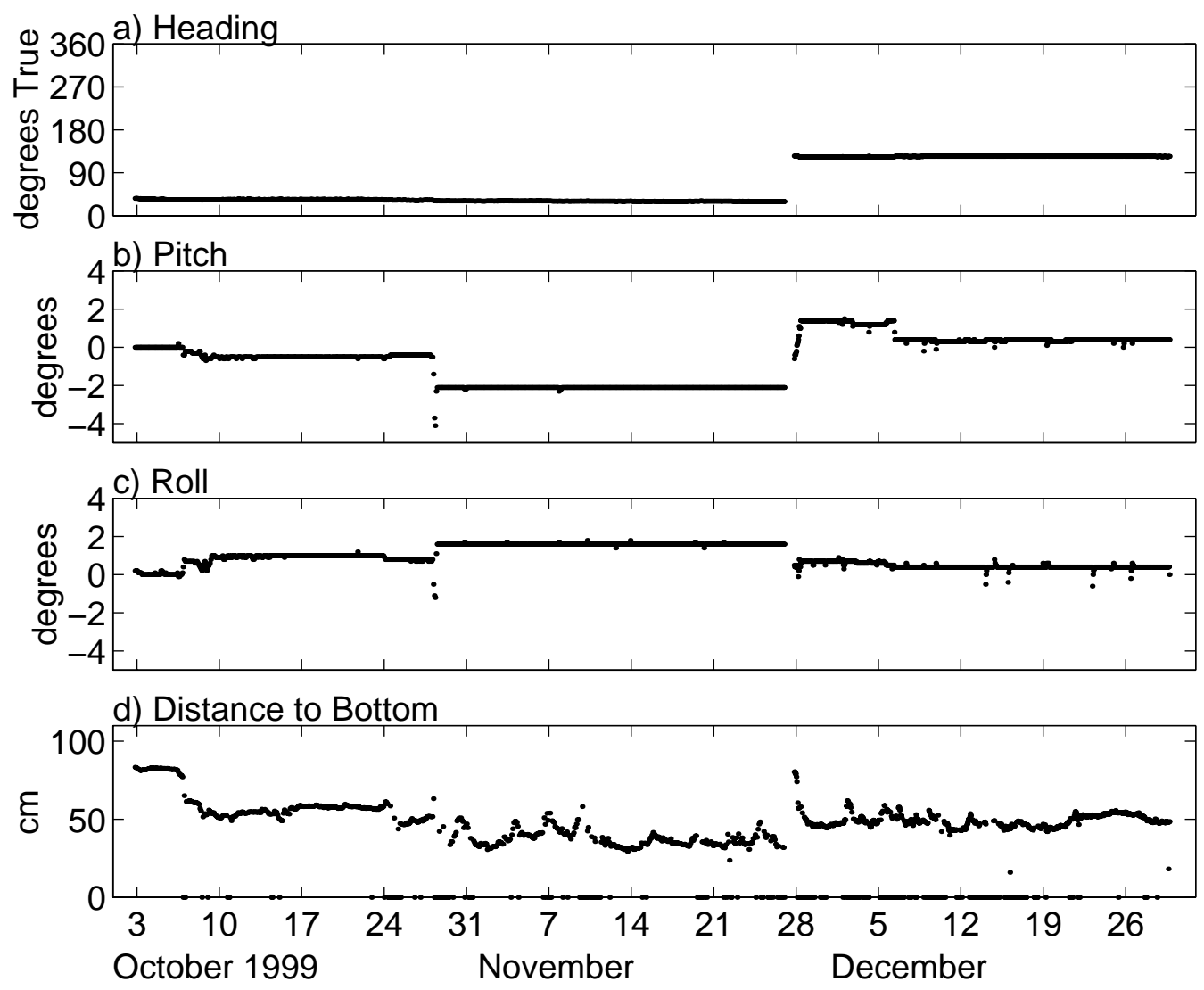

Figure 41. Time series of heading, pitch, roll, and distance to the bottom from data collected by the ADV at Site MD. 

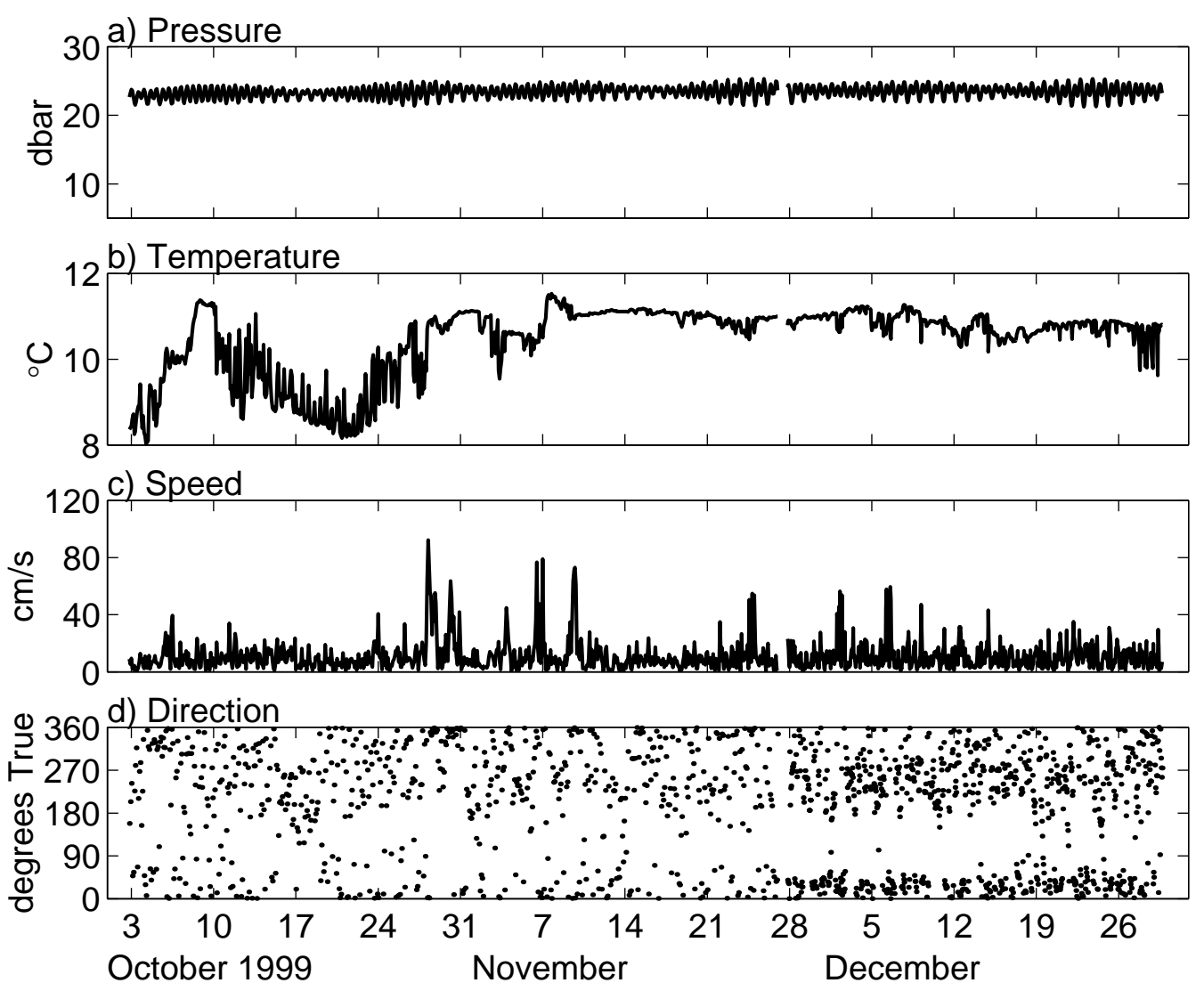

Figure 42. Time series of pressure, temperature, speed, and direction from data collected by the ADV at Site MD. 

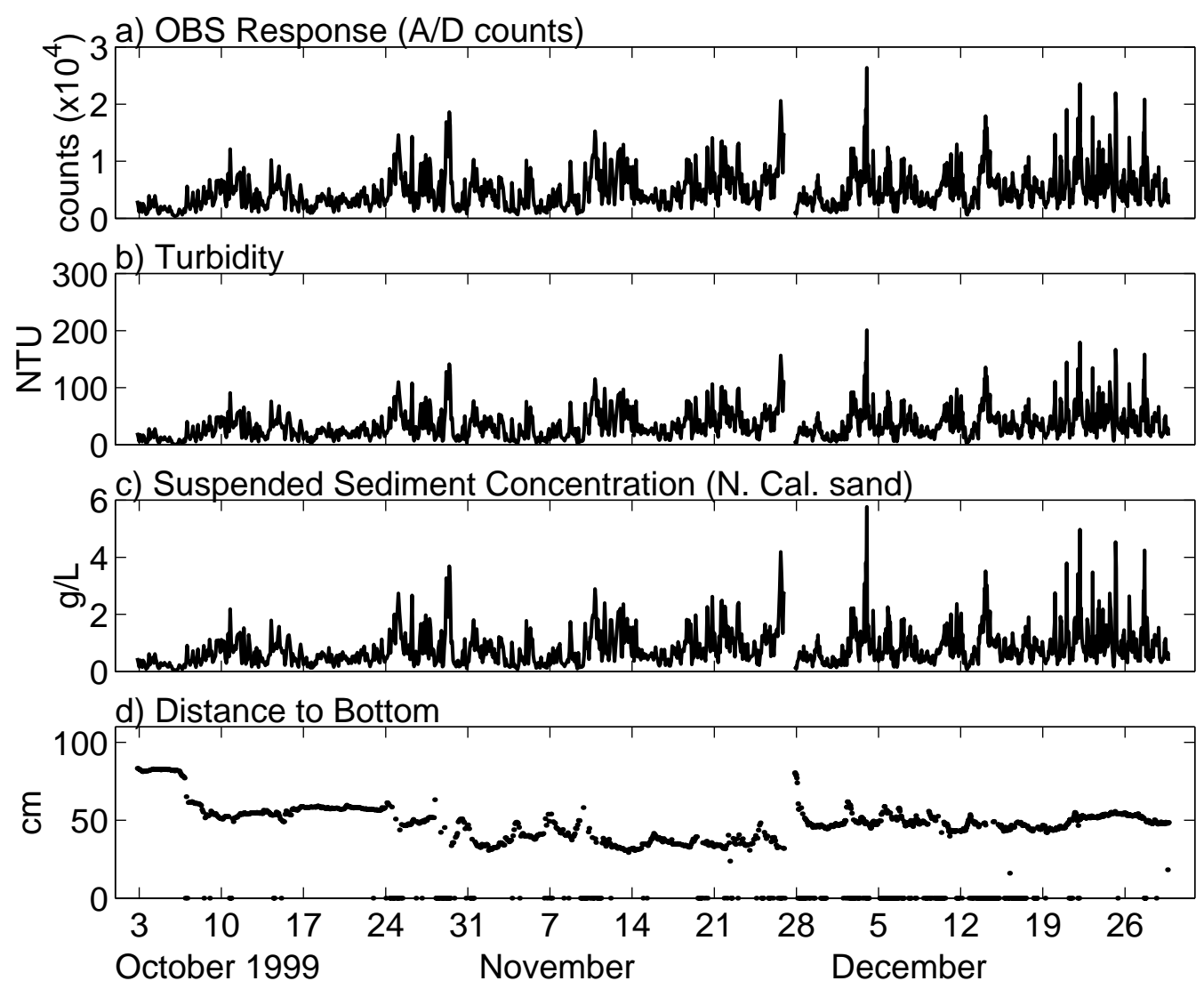

Figure 43. Time series of the response of the OBS, turbidity, suspended sediment concentration, and distance to the bottom for Site MD. 

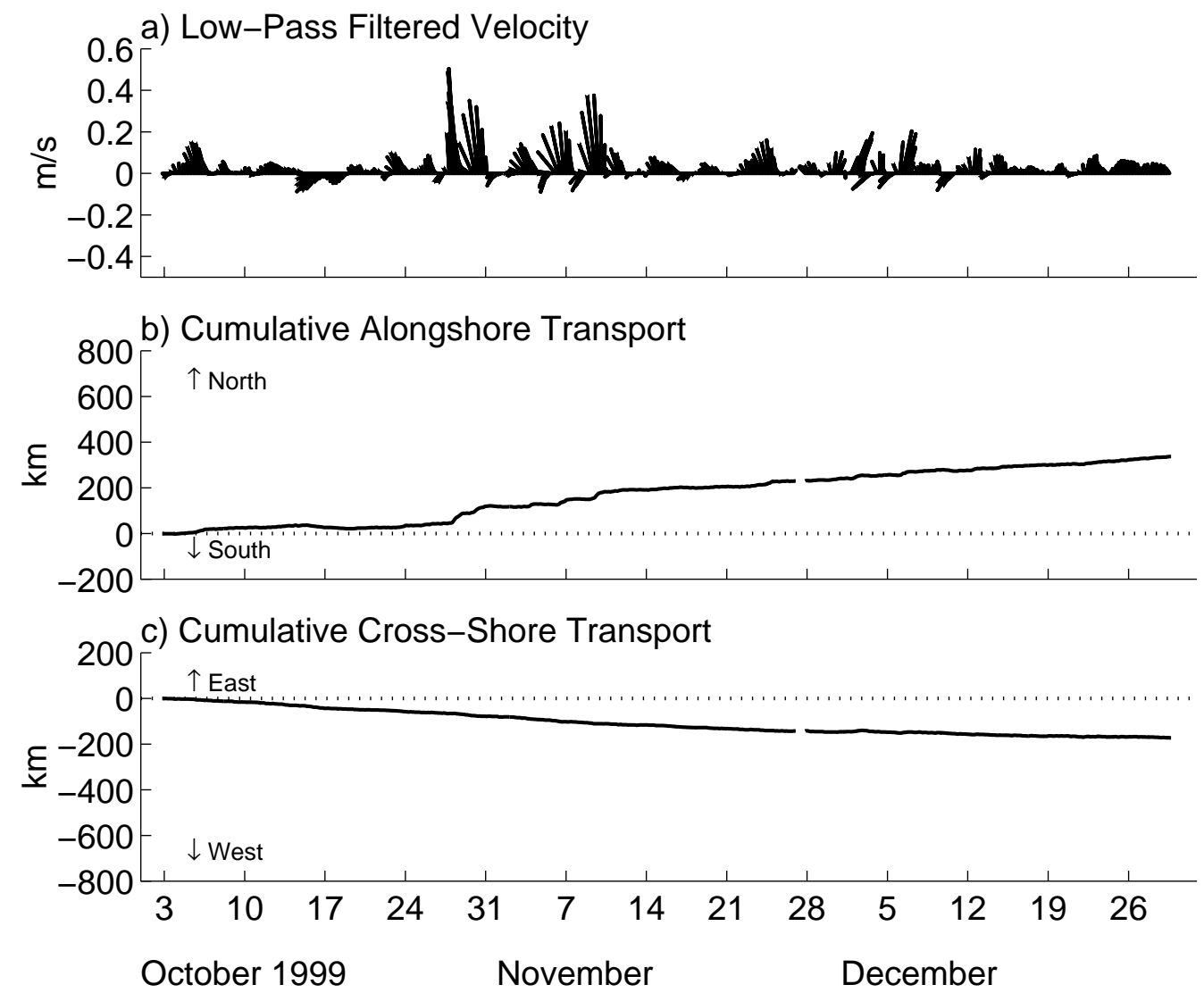

Figure 44. Time series of low-pass filtered velocity and cumulative alongshore and cross-shore transport for Site MD. 

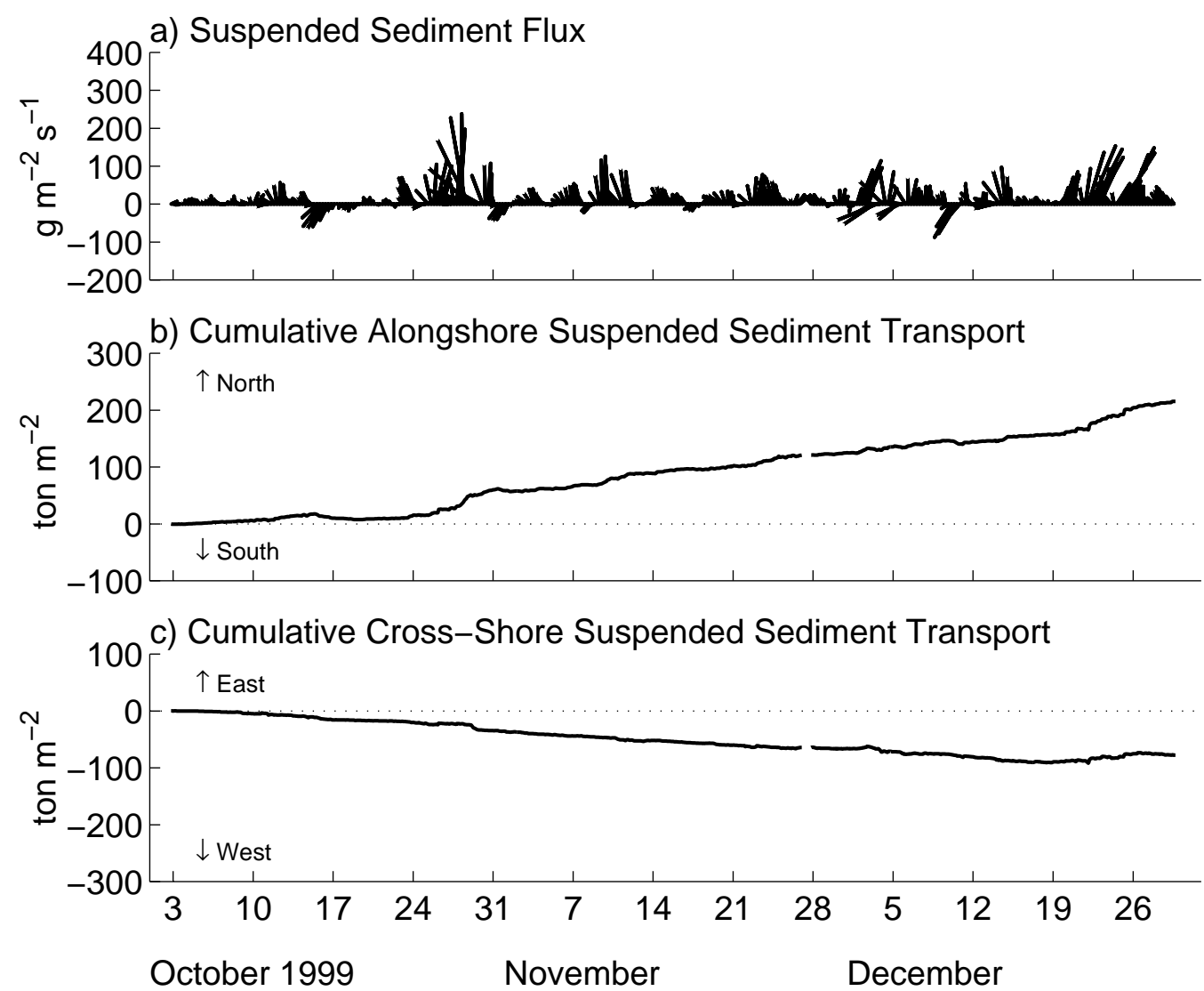

Figure 45. Time series of suspended sediment flux and cumulative alongshore and cross-shore suspended sediment transport for Site MD. 

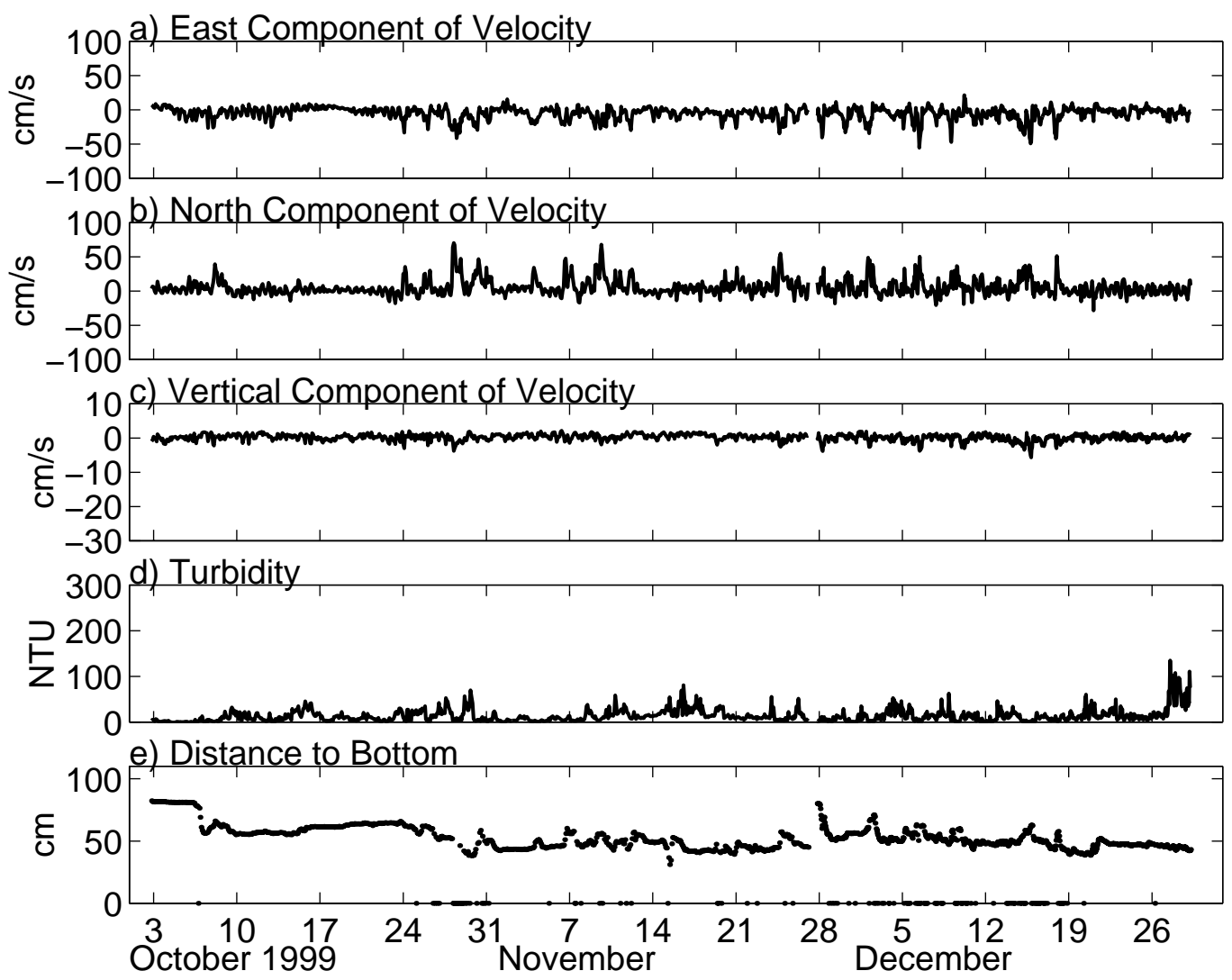

Figure 46. Time series of east (positive eastward), north (positive northward), and vertical (positive up) velocity components, turbidity, and distance to the bottom from data collected by the ADV at Site SD. 

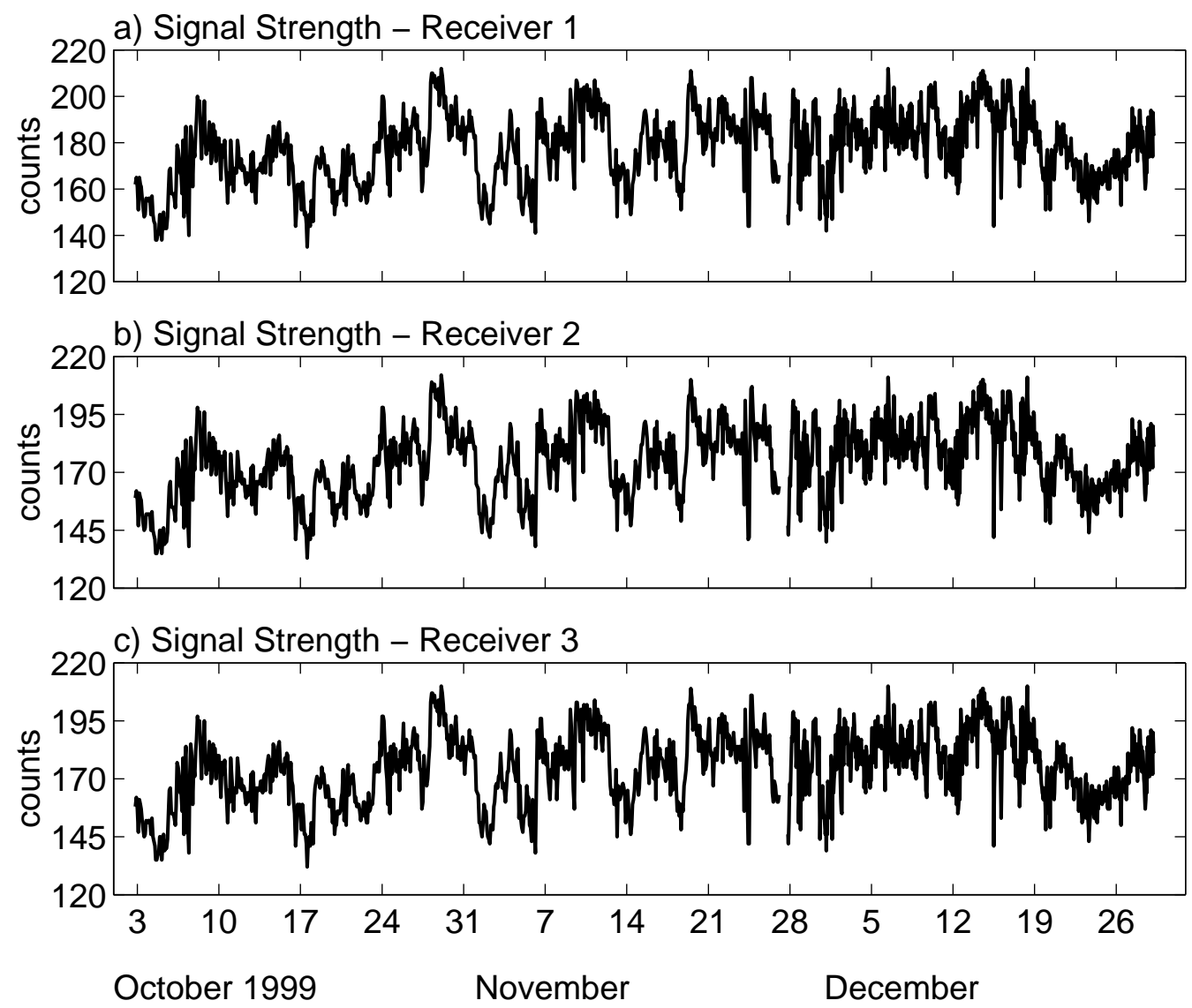

Figure 47. Time series of signal strength collected for each ADV receiver at Site SD. 

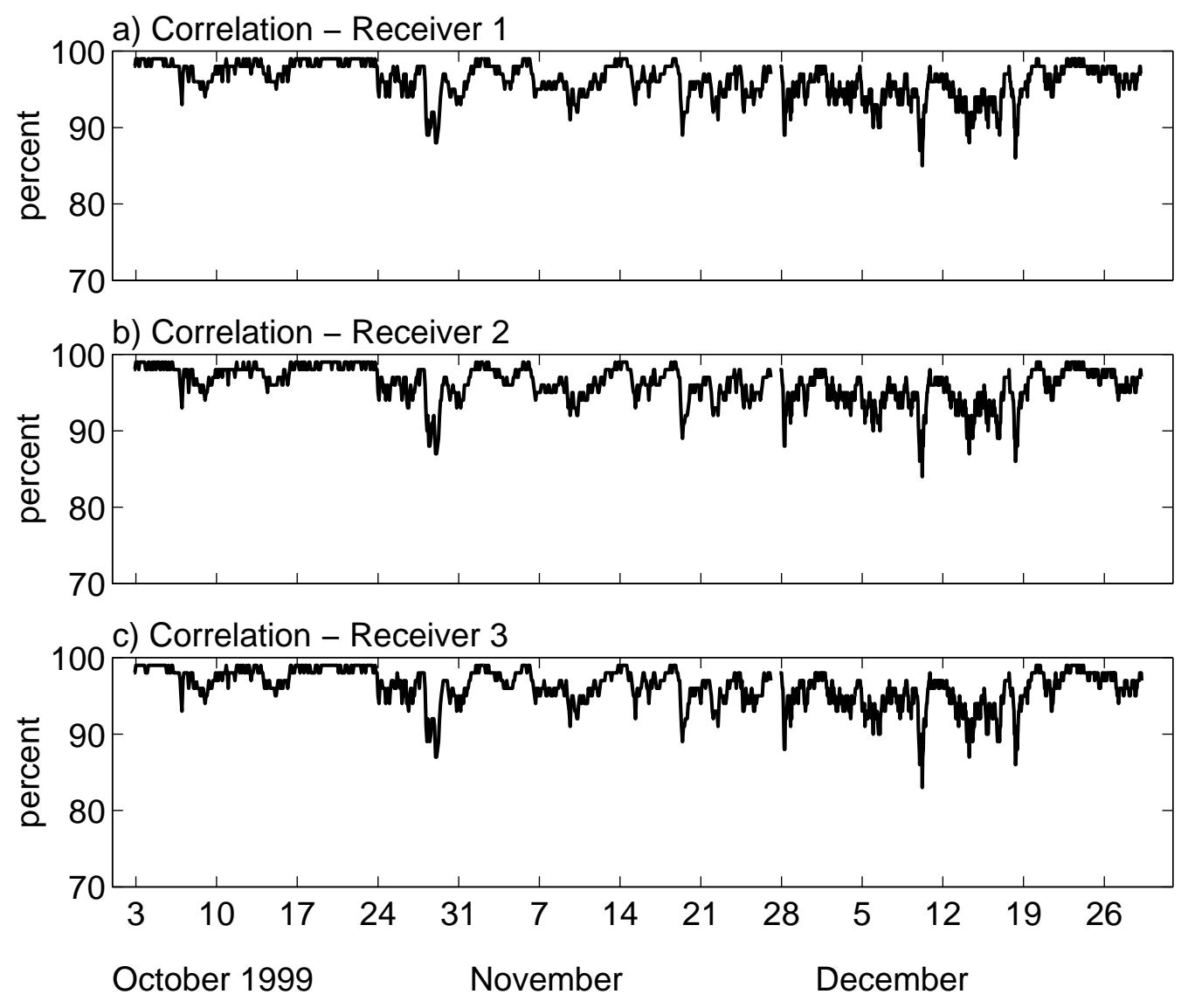

Figure 48. Time series of signal correlation for ADV receivers at Site SD. 

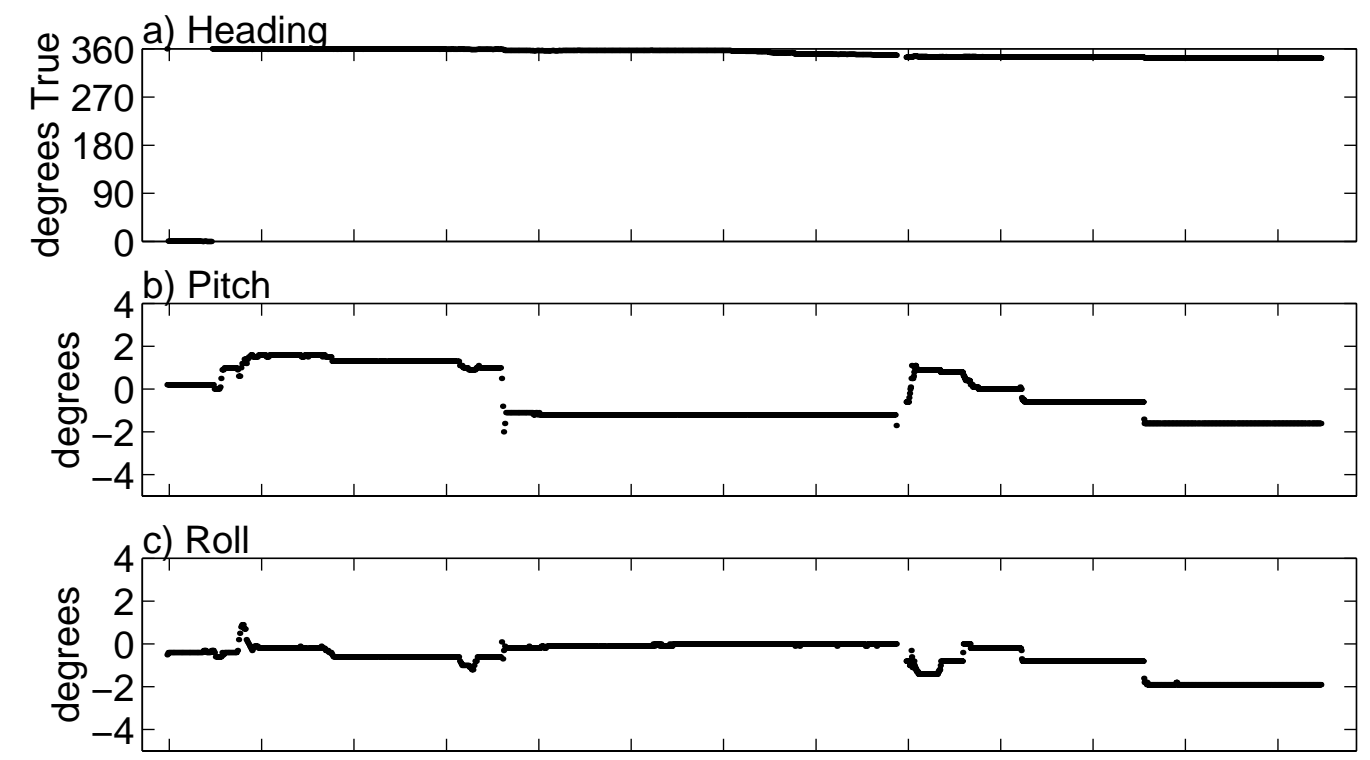

d) Distance to Bottom

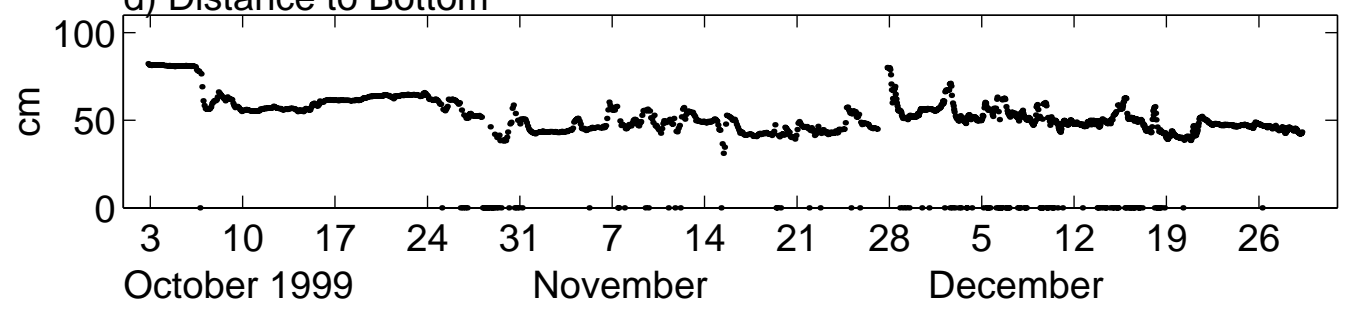

Figure 49. Time series of heading, pitch, roll, and distance to the bottom from data collected by the ADV at Site SD. 

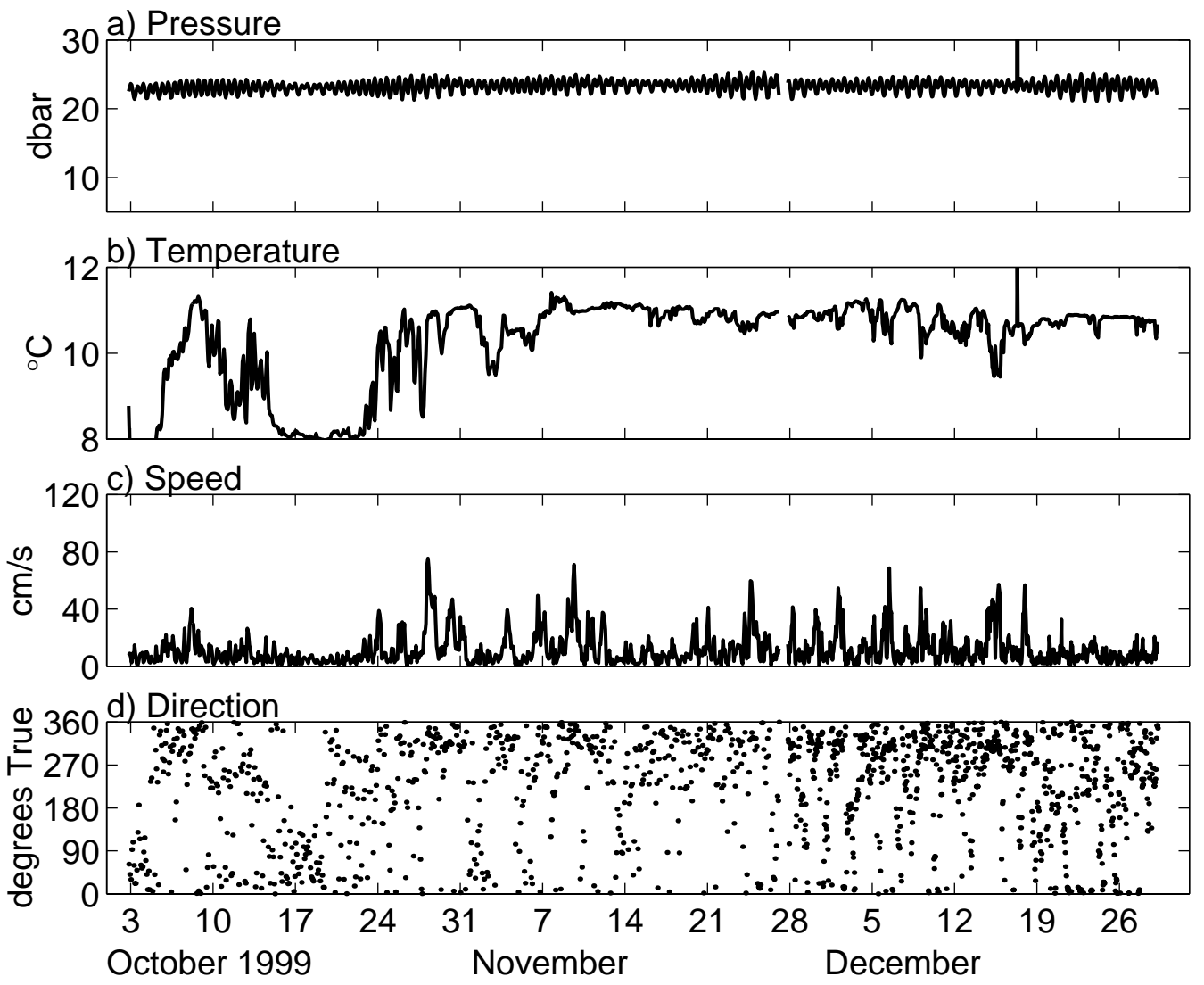

Figure 50. Time series of pressure, temperature, speed, and direction from data collected by the ADV at Site SD. 


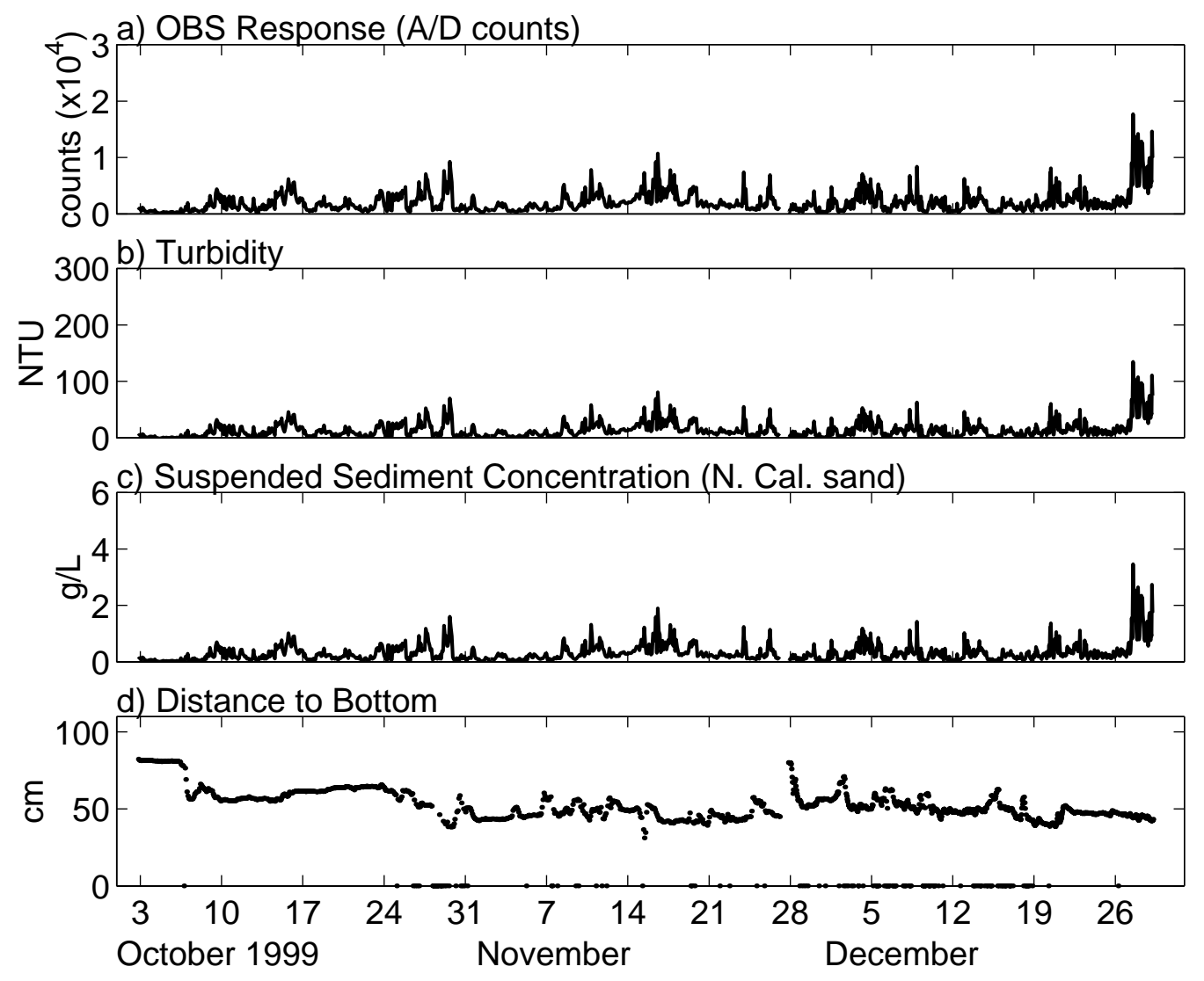

Figure 51. Time series of the response of the OBS, turbidity, suspended sediment concentration, and distance to the bottom for Site SD. 

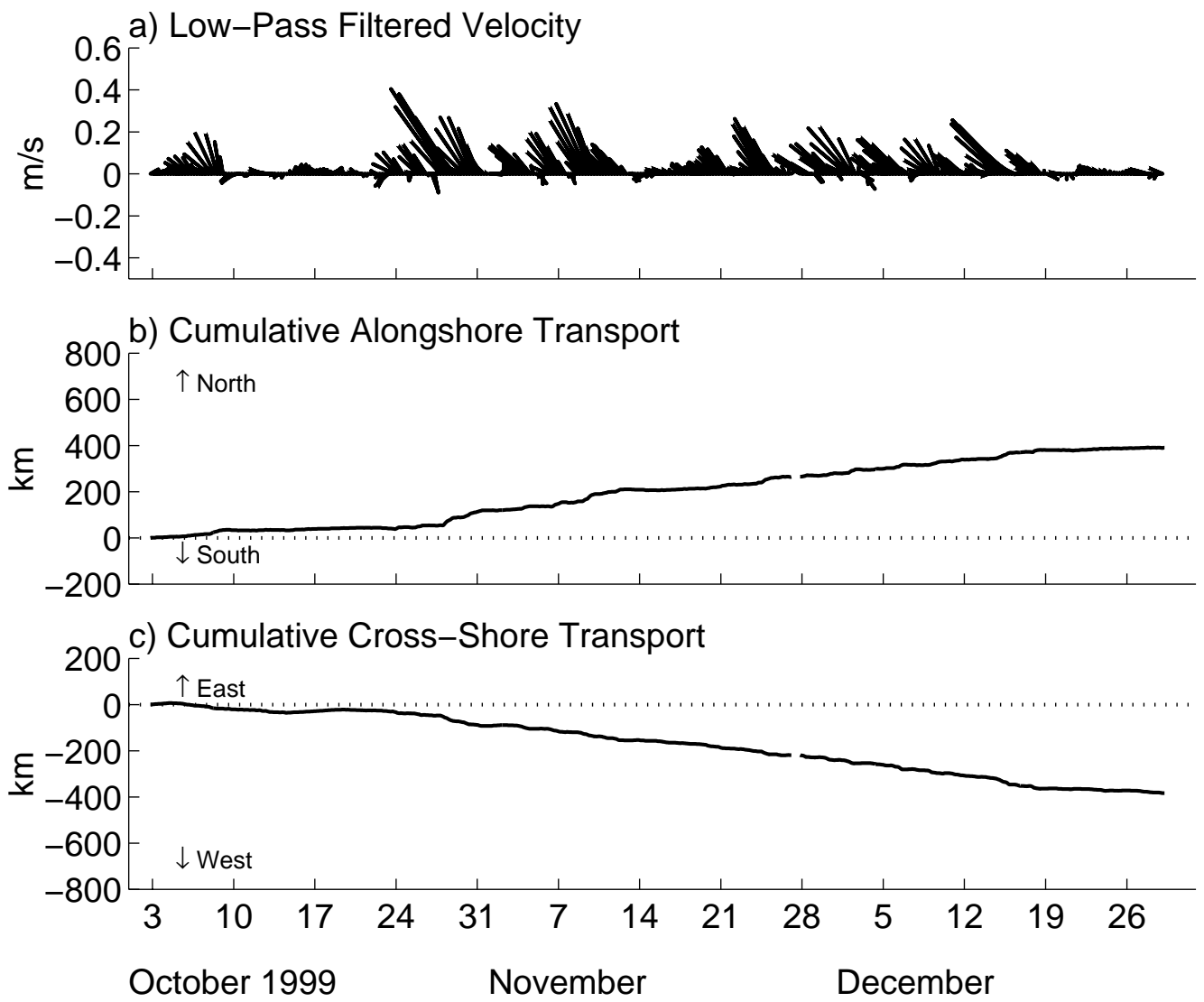

Figure 52. Time series of low-pass filtered velocity and cumulative alongshore and cross-shore transport for Site SD. 

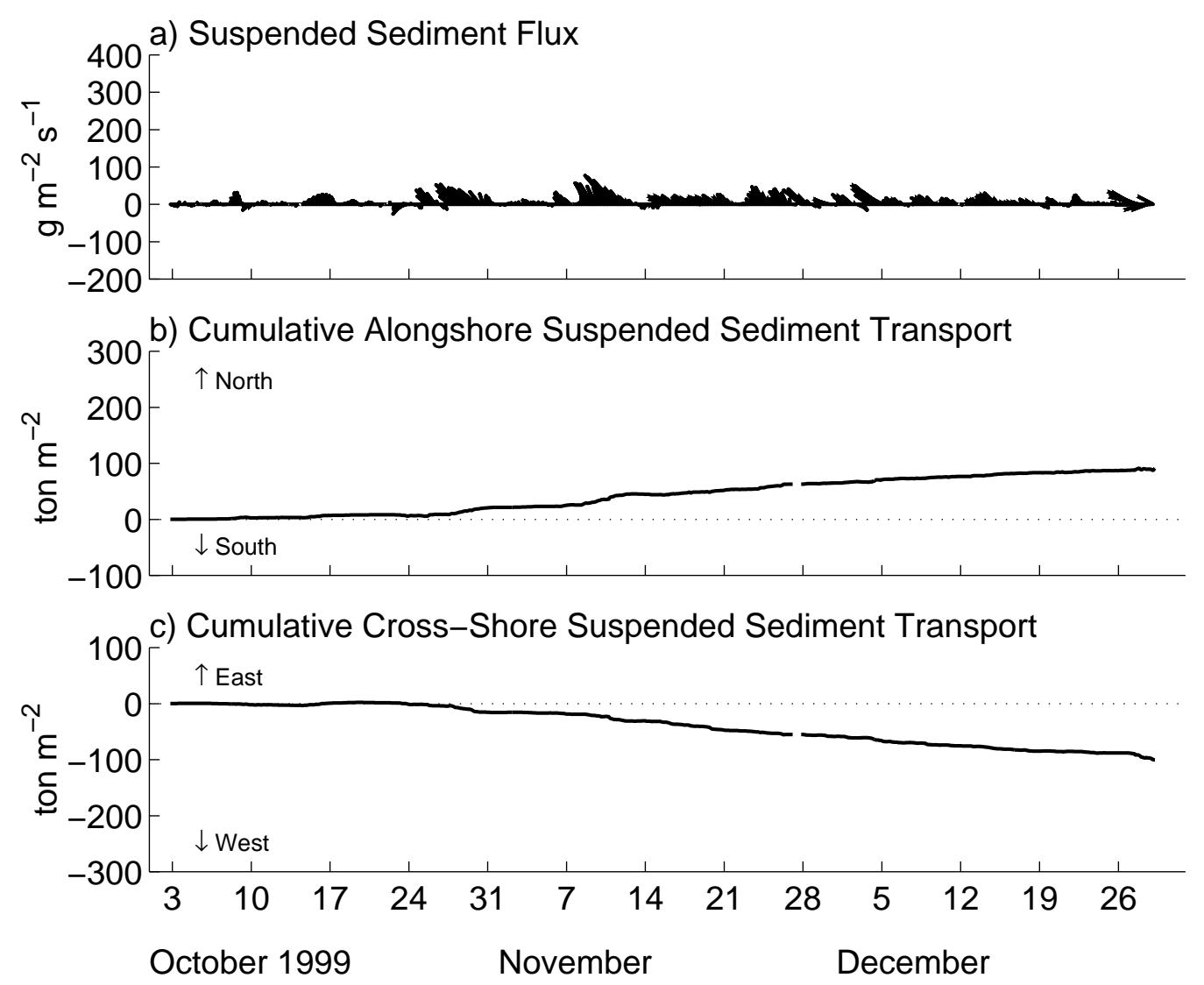

Figure 53. Time series of suspended sediment flux and cumulative alongshore and cross-shore suspended sediment transport for Site SD. 
a) Significant Wave Height $H_{s}$

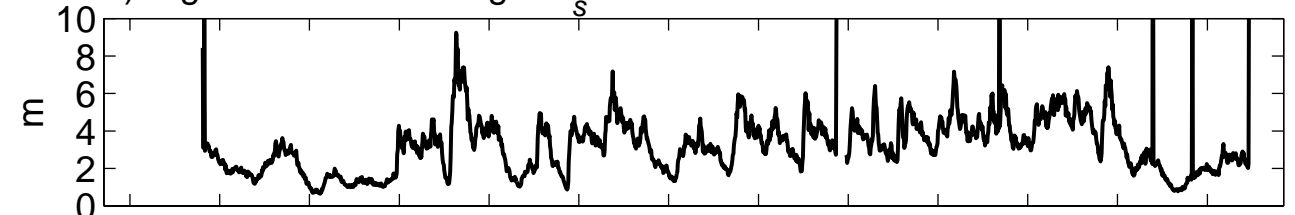

b) Mean Period $T$
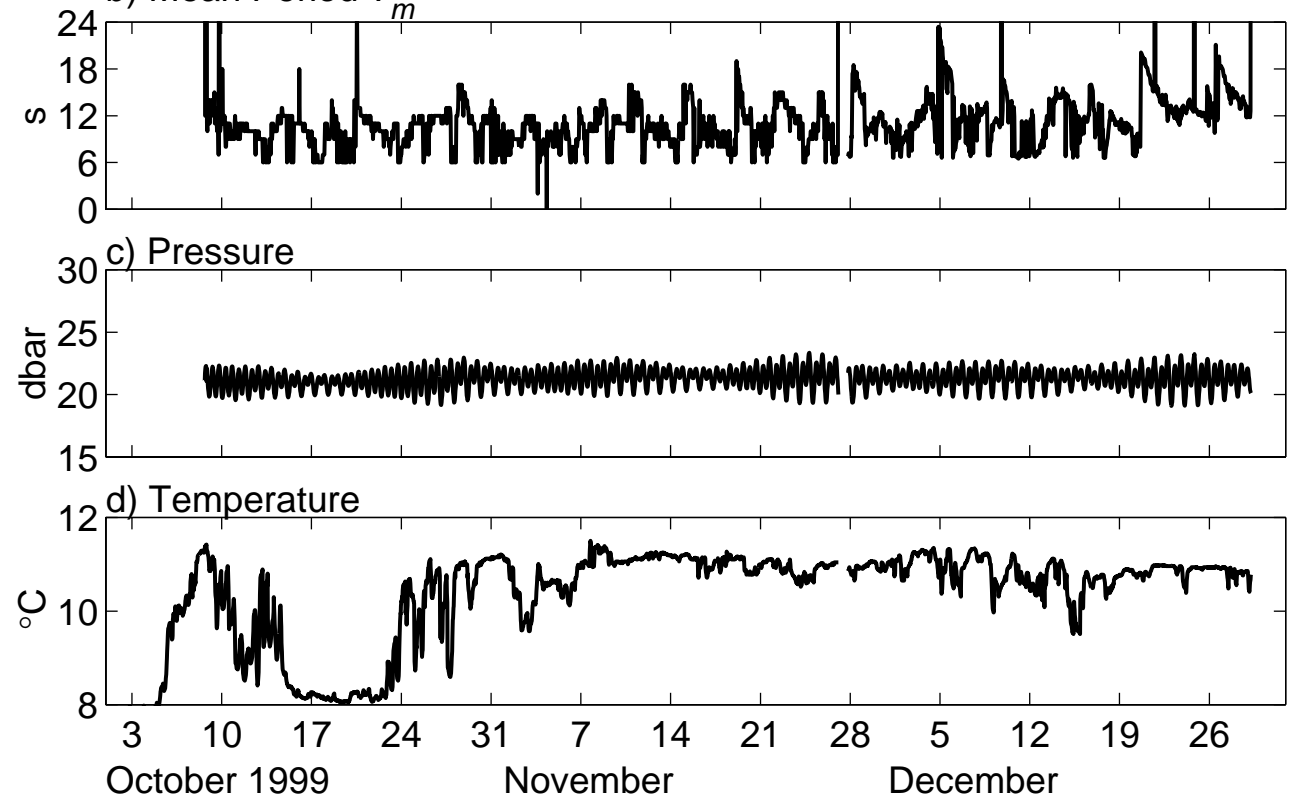

Figure 54. Time series of significant wave height, mean period, pressure, and temperature from data collected by the ADP at Site SD. 

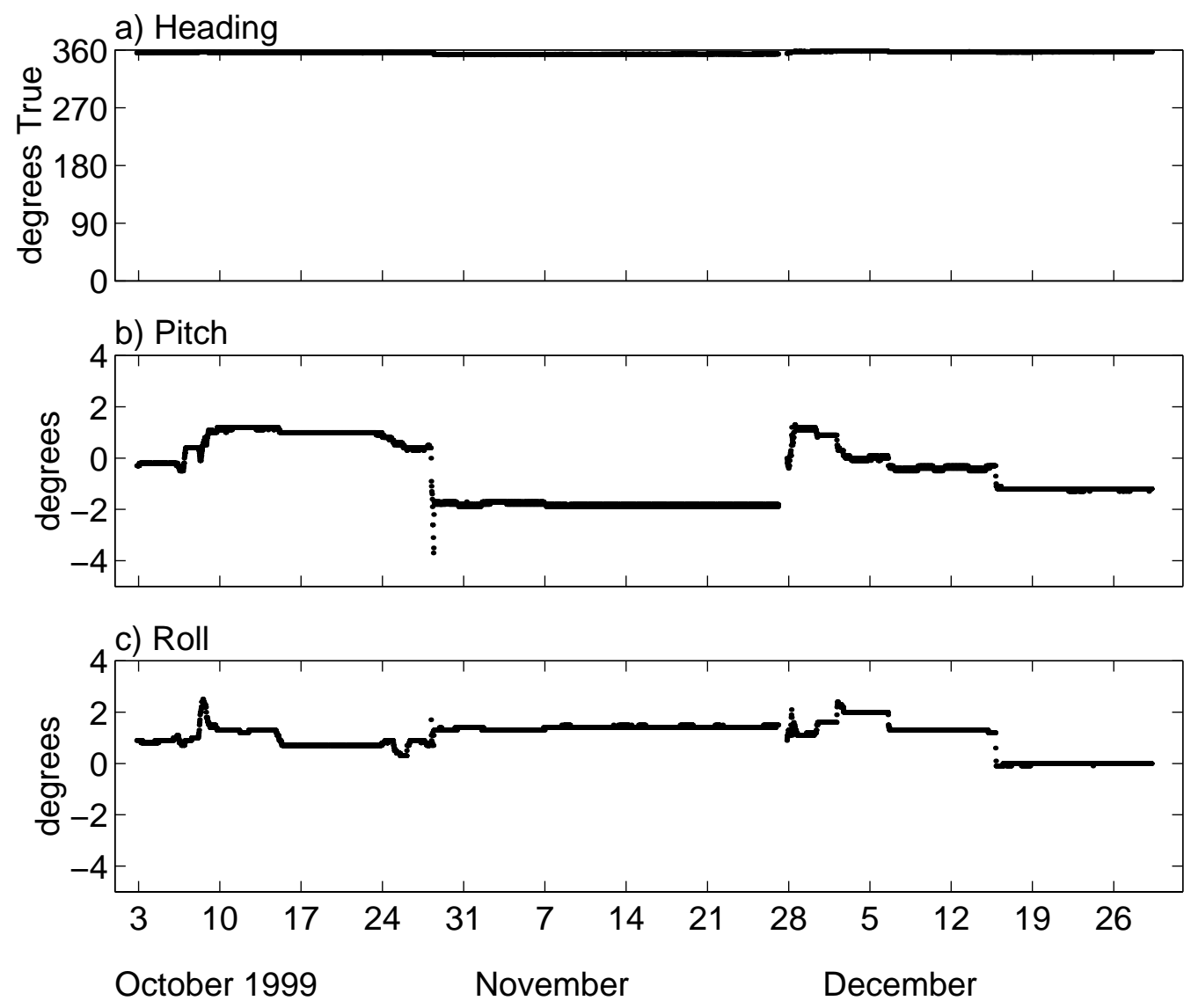

Figure 55. Time series of heading, pitch, and roll from data collected by the ADP at Site SD. 


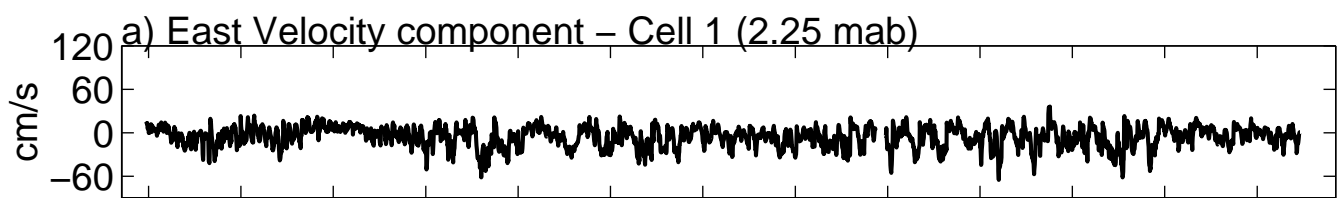

120 b) North Velocity Component - Cell 1 (2.25 mab)
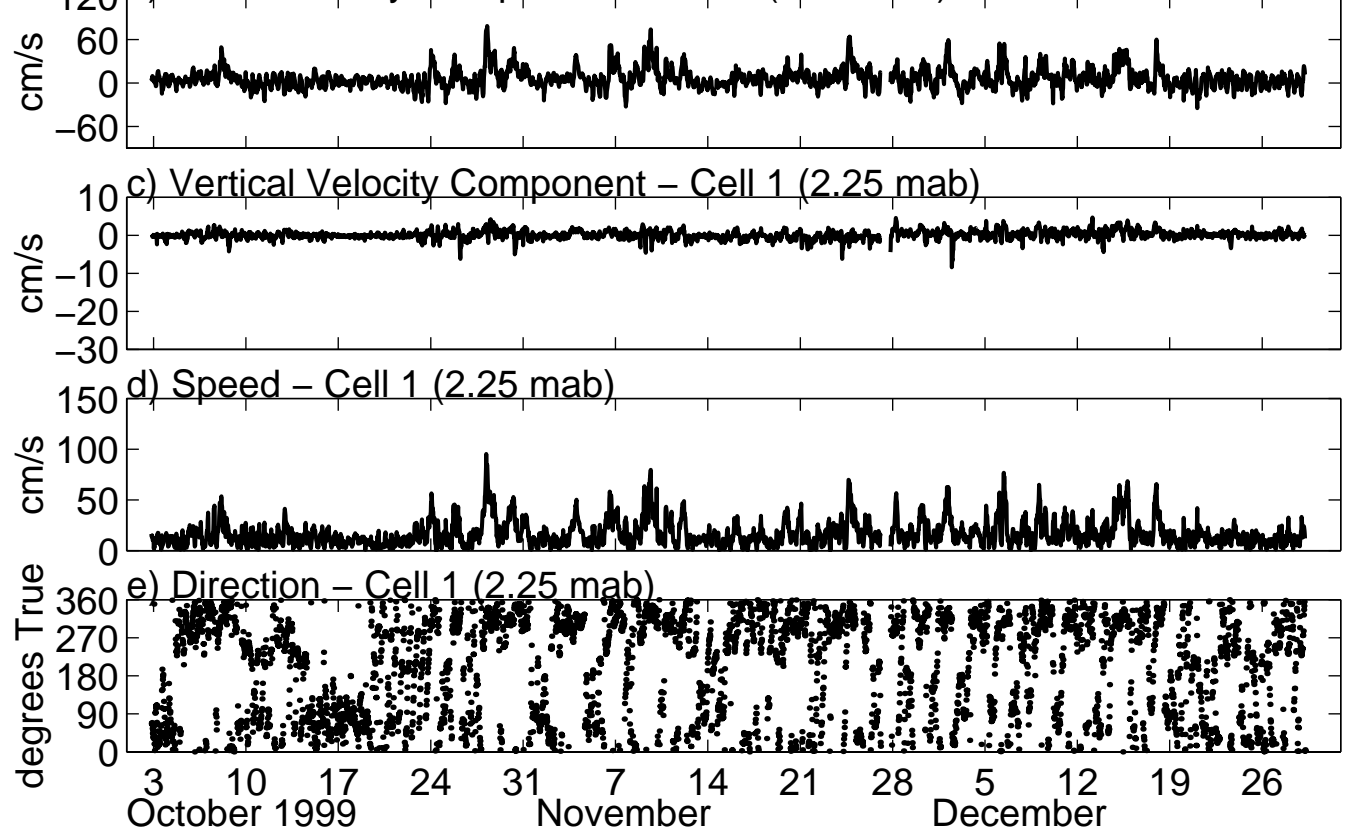

Figure 56. Time series of east (positive eastward), north (positive northward), and vertical (positive up) velocity components, speed, and direction in cell 1 (2.25 mab) from data collected by the ADP at Site SD. 

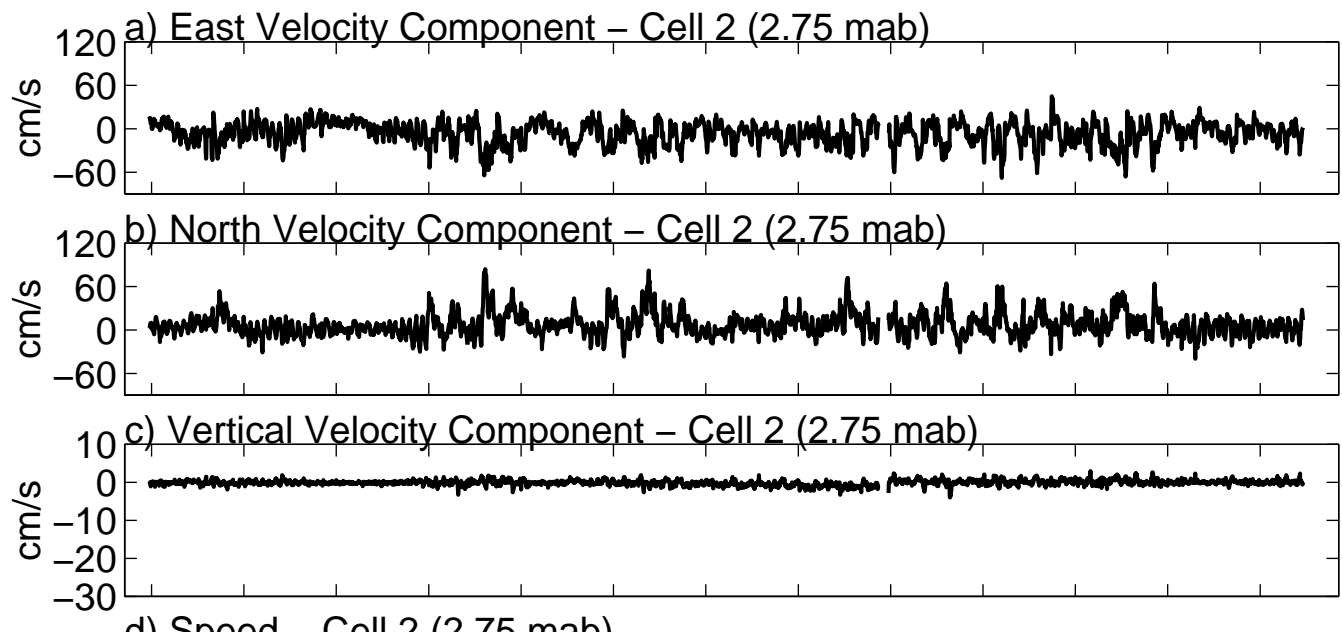

150 d) Speed - Cell 2 (2.75 mab)
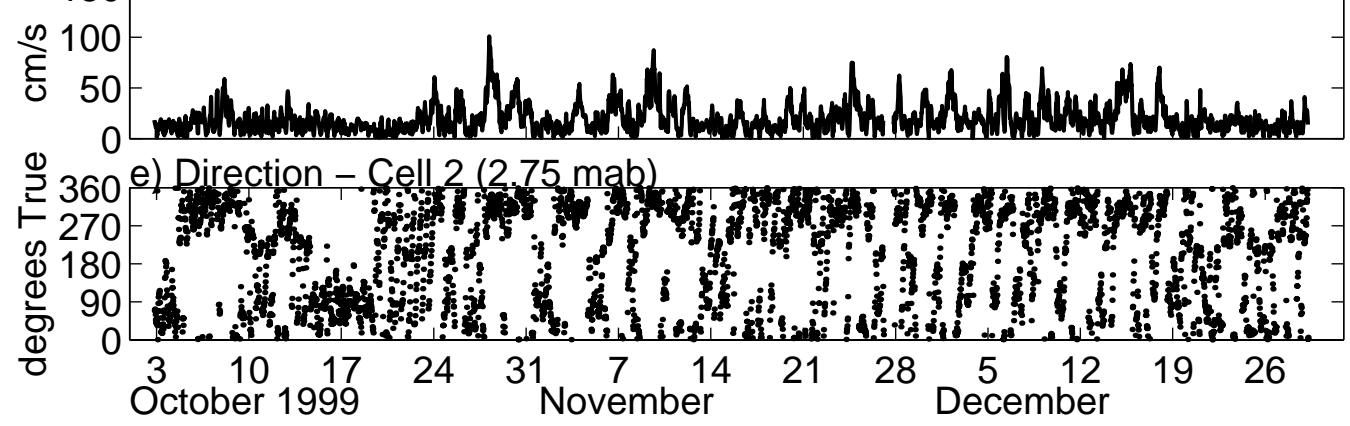

Figure 57. Time series of east (positive eastward), north (positive northward), and vertical (positive up) velocity components, speed, and direction in cell 2 ( $2.75 \mathrm{mab})$ from data collected by the ADP at Site SD. 

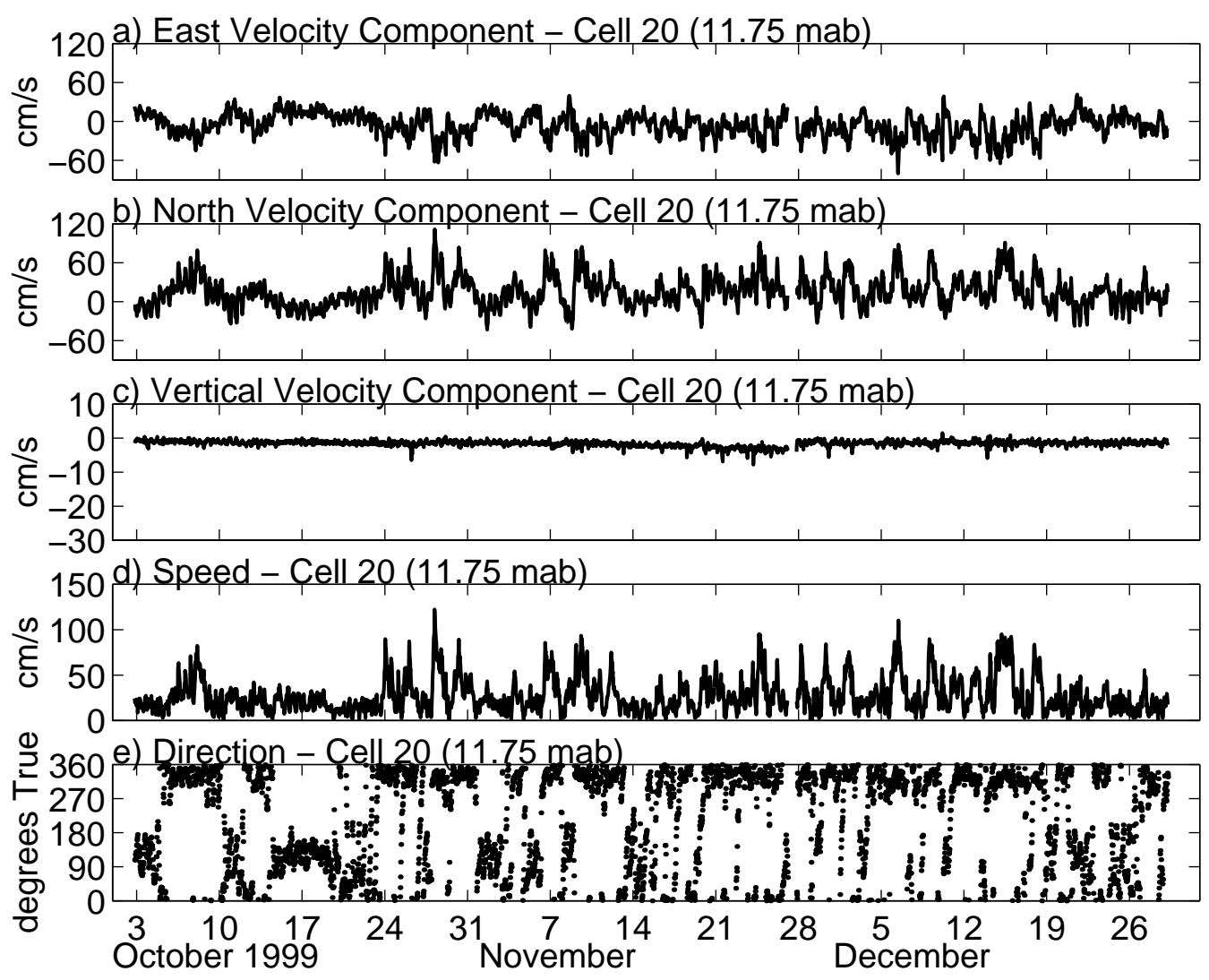

Figure 58. Time series of east (positive eastward), north (positive northward), and vertical (positive up) velocity components, speed, and direction in cell 20 (11.75 mab) from data collected by the ADP at Site SD. 

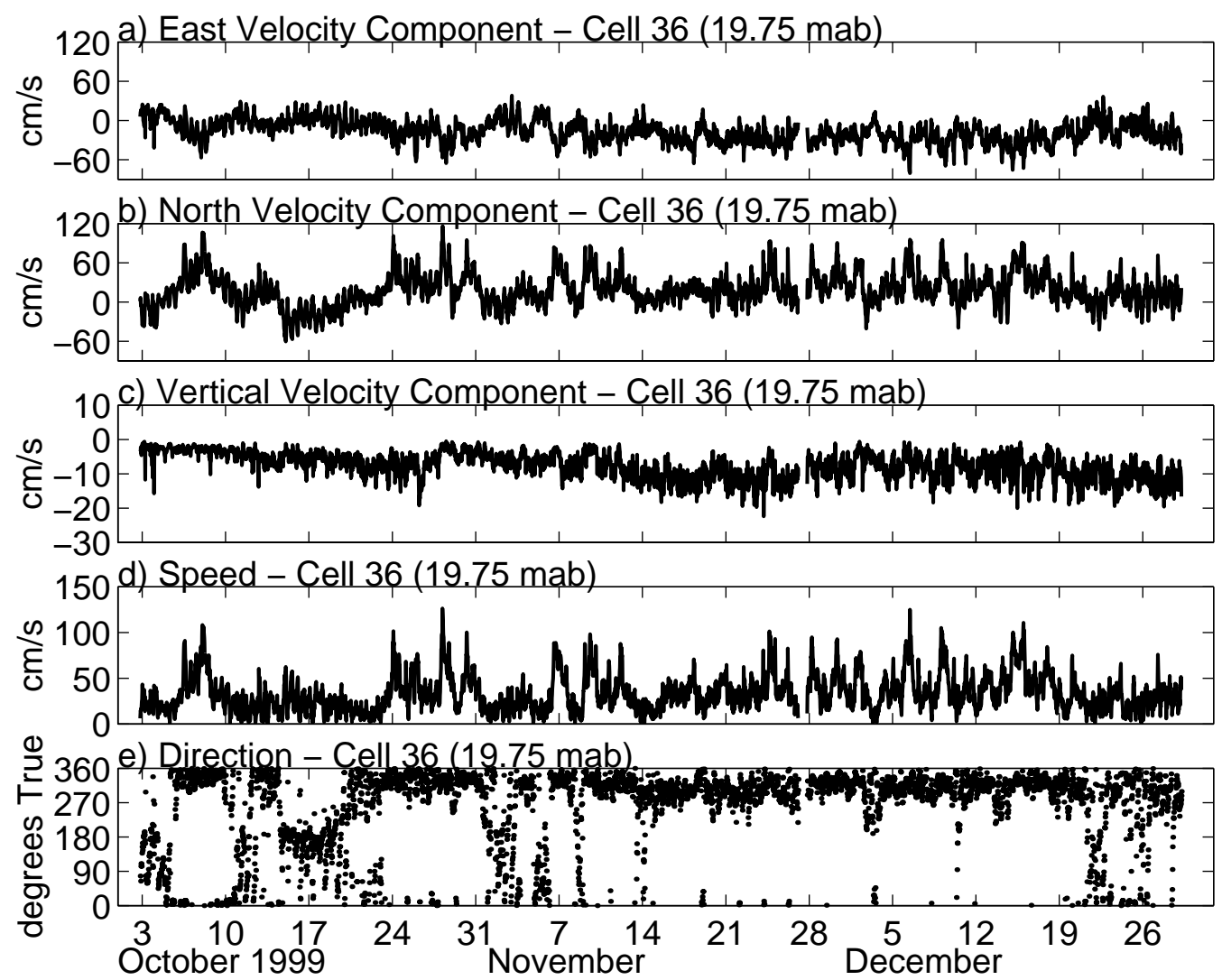

Figure 59. Time series of east (positive eastward), north (positive northward), and vertical (positive up) velocity components, speed, and direction in cell 36 (19.75 mab) from data collected by the ADP at Site SD. 

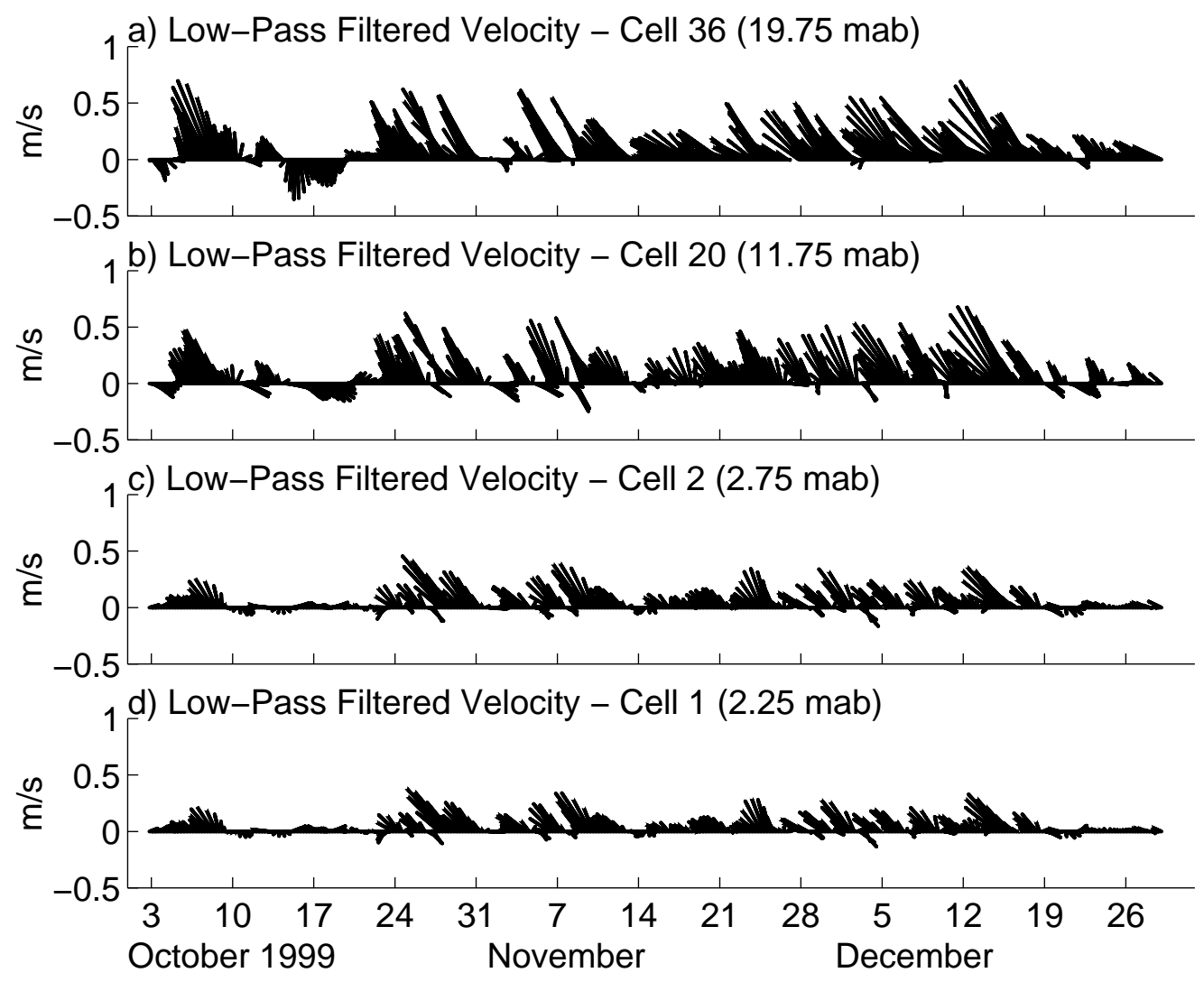

Figure 60. Time series of low-pass filtered velocity for several ADP cells at Site SD. 


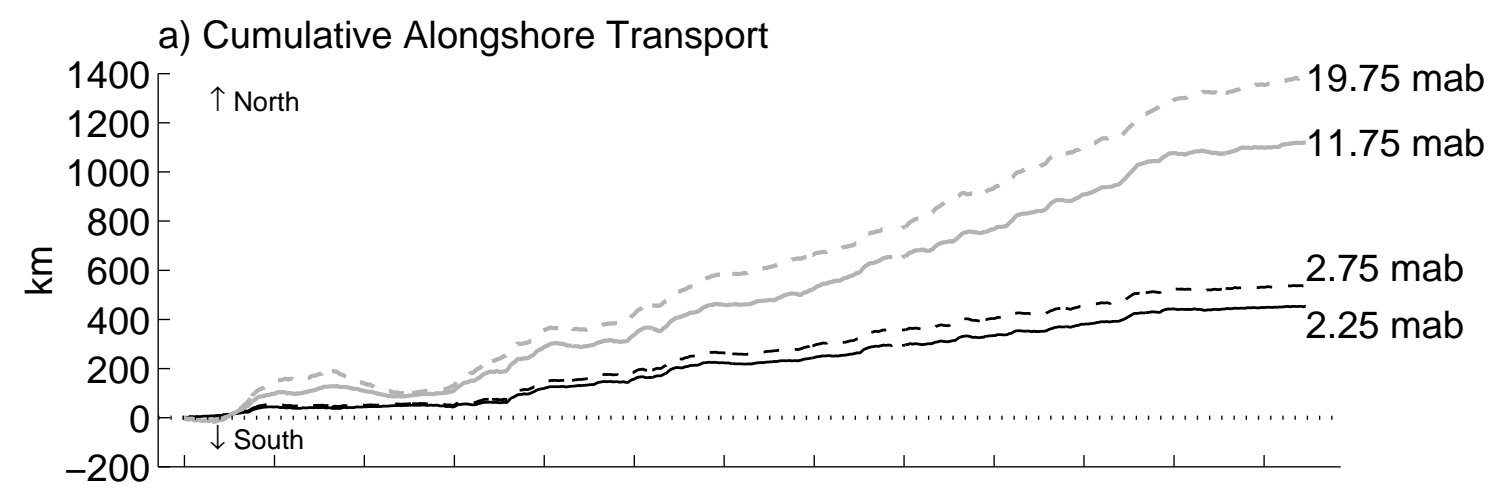

b) Cumulative Cross-Shore Transport

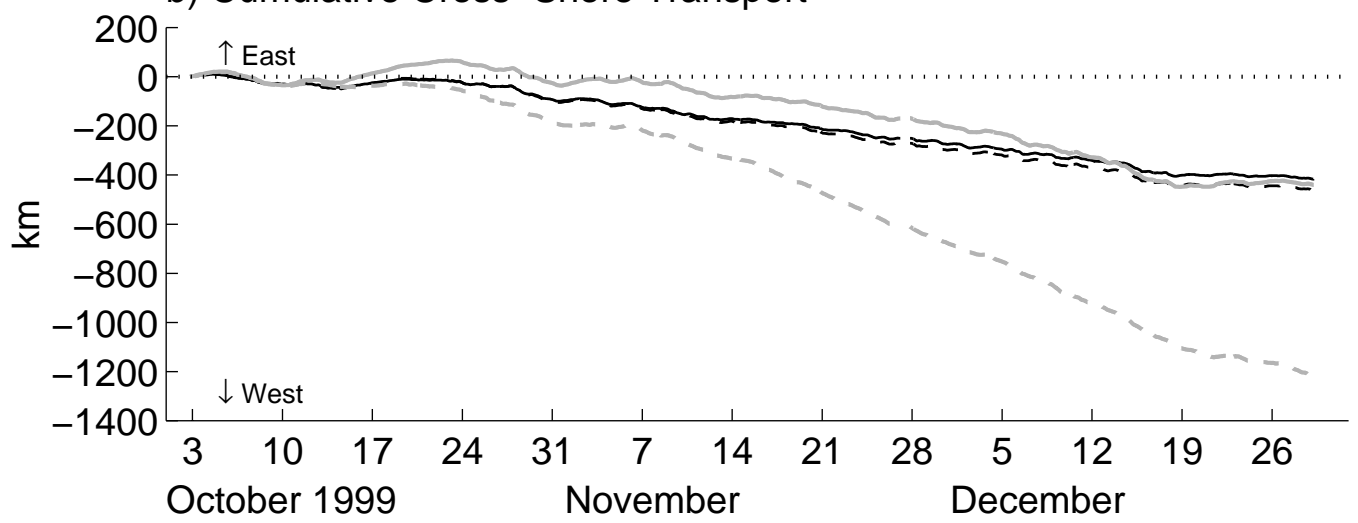

Figure 61. Time series of cumulative alongshore and cross-shore transport for several ADP cells at Site SD. 


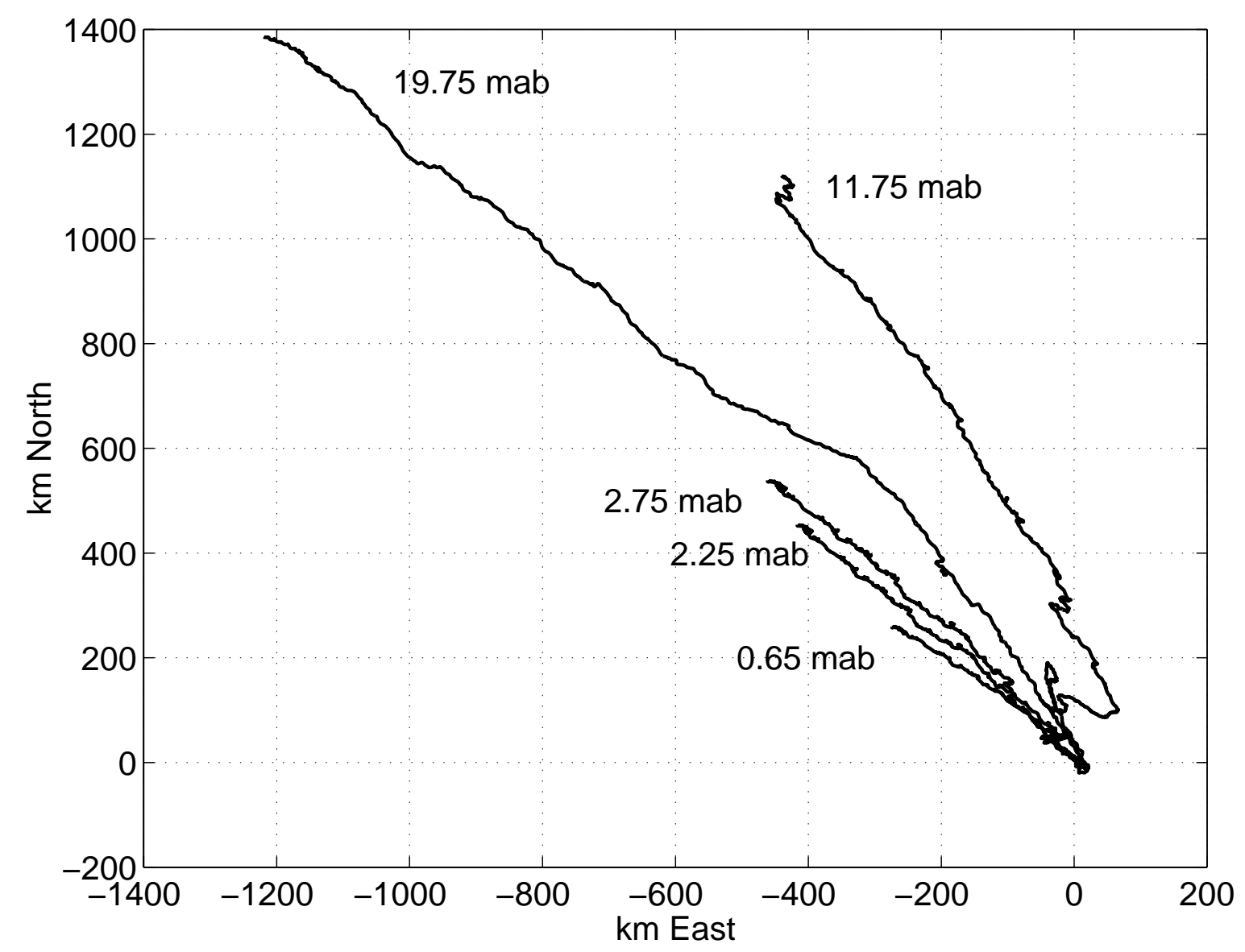

Figure 62. Progressive vector diagram of currents at Site SD.Measurement period for the ADP (elevations 2.25 to $19.75 \mathrm{mab}$ ) was 10/02/99-11/27/99 and 11/27/99-12/29/99. Measurement period for the ADV (0.65 mab) was 10/02/99-11/27/99 and 11/27/99-12/29/99. 


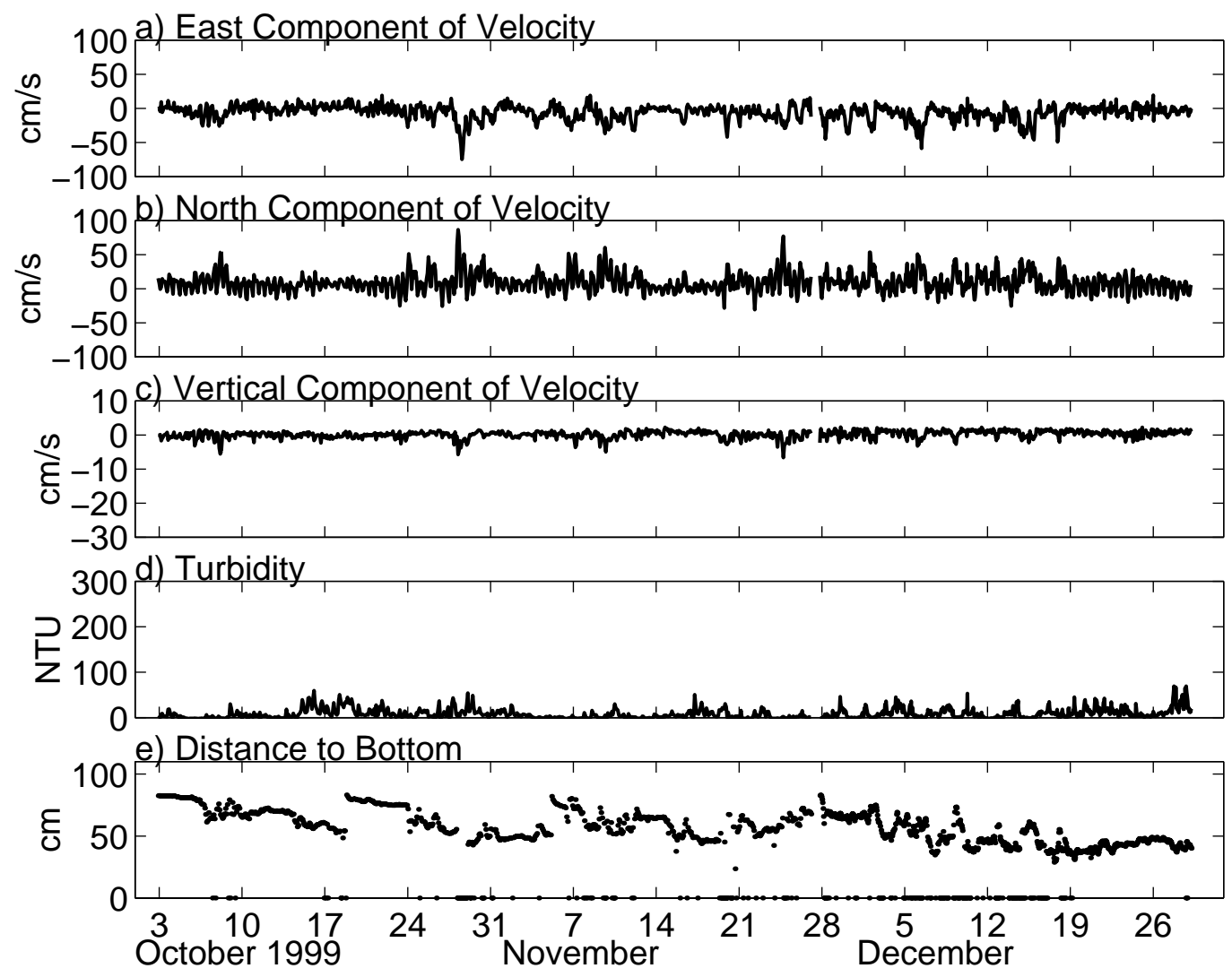

Figure 63. Time series of east (positive eastward), north (positive northward), and vertical (positive up) velocity components, turbidity, and distance to the bottom from data collected by the ADV at Site SS. 

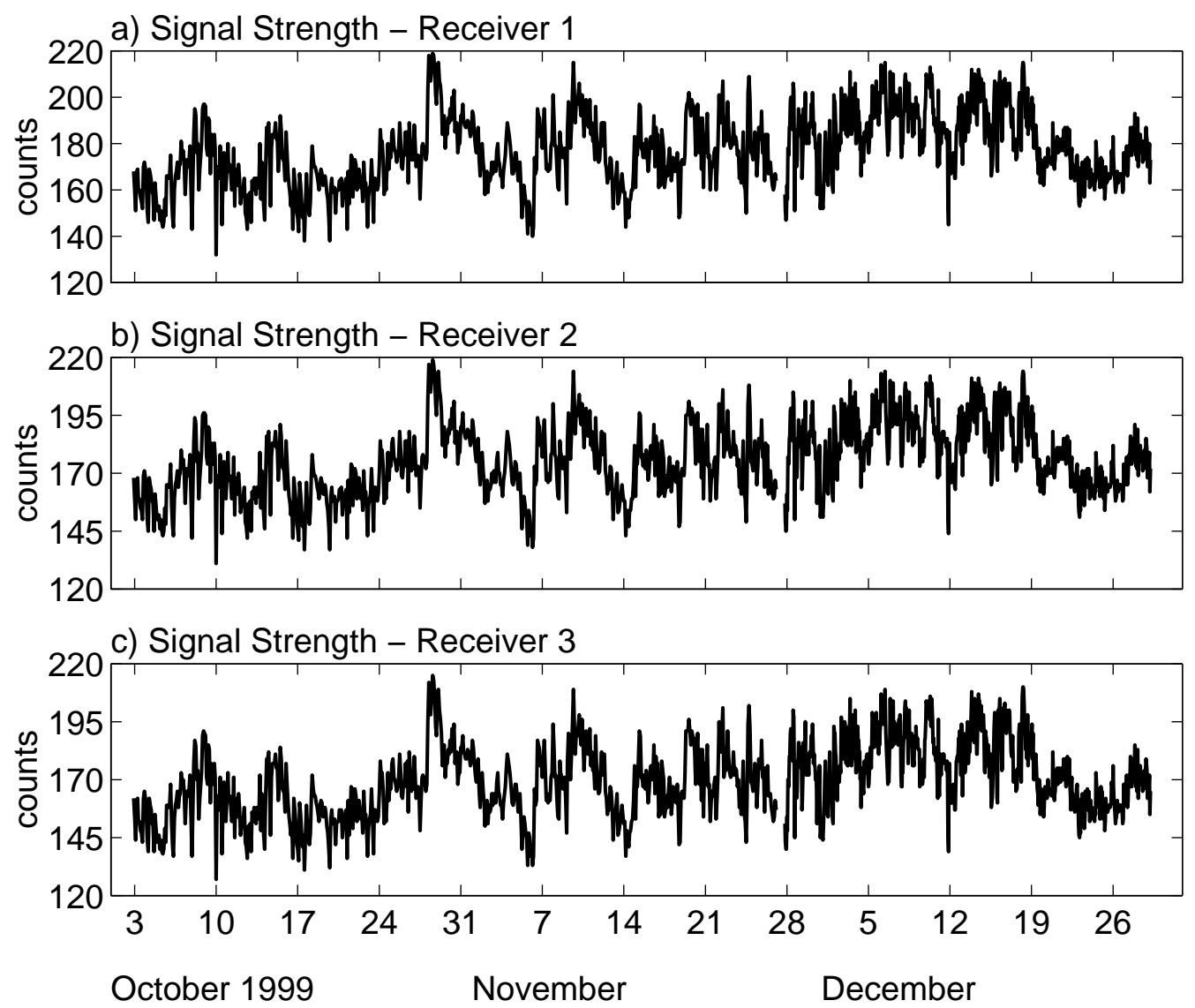

Figure 64. Time series of signal strength collected for each ADV receiver at Site SS. 

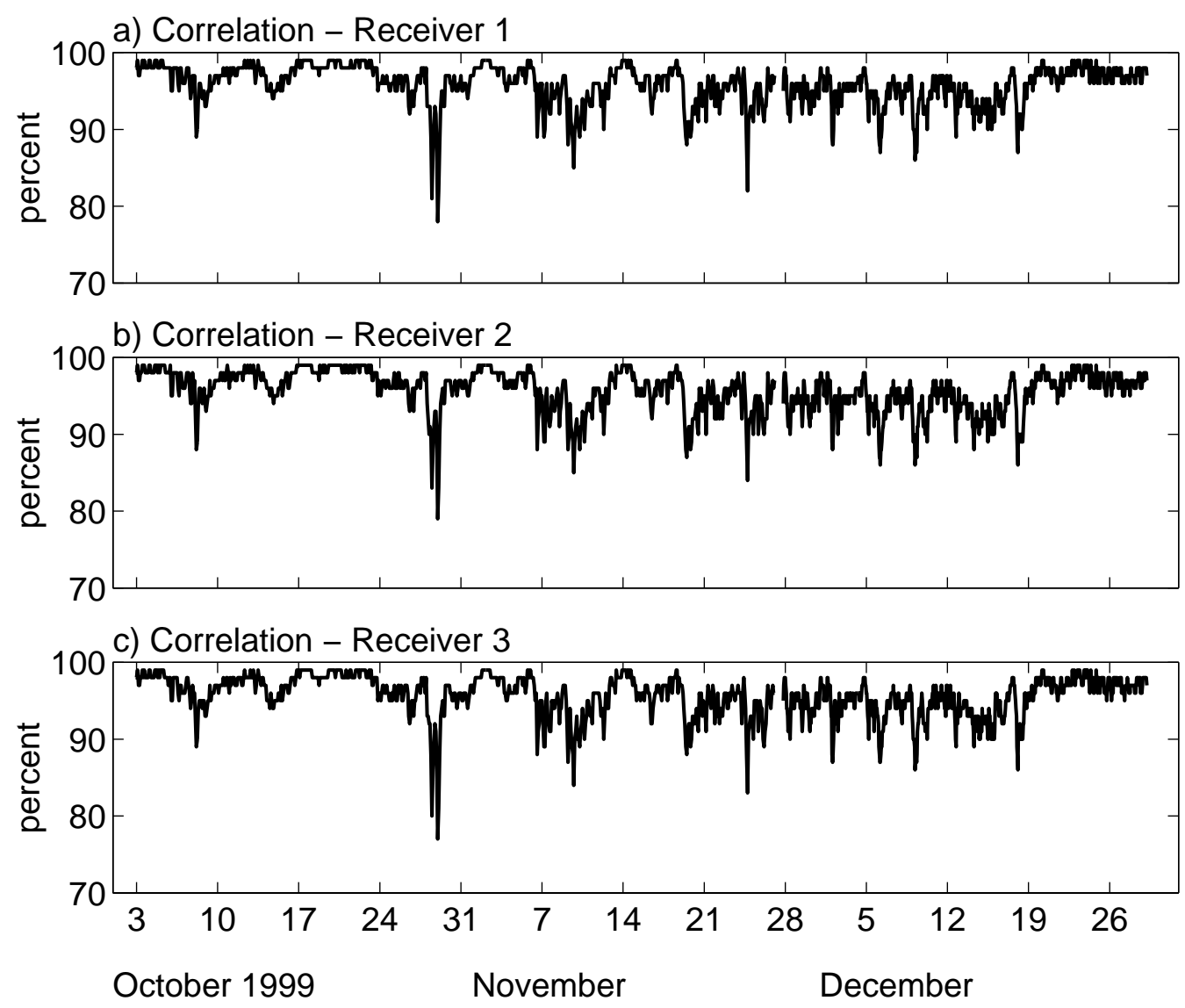

Figure 65. Time series of signal correlation for ADV receivers at Site SS. 

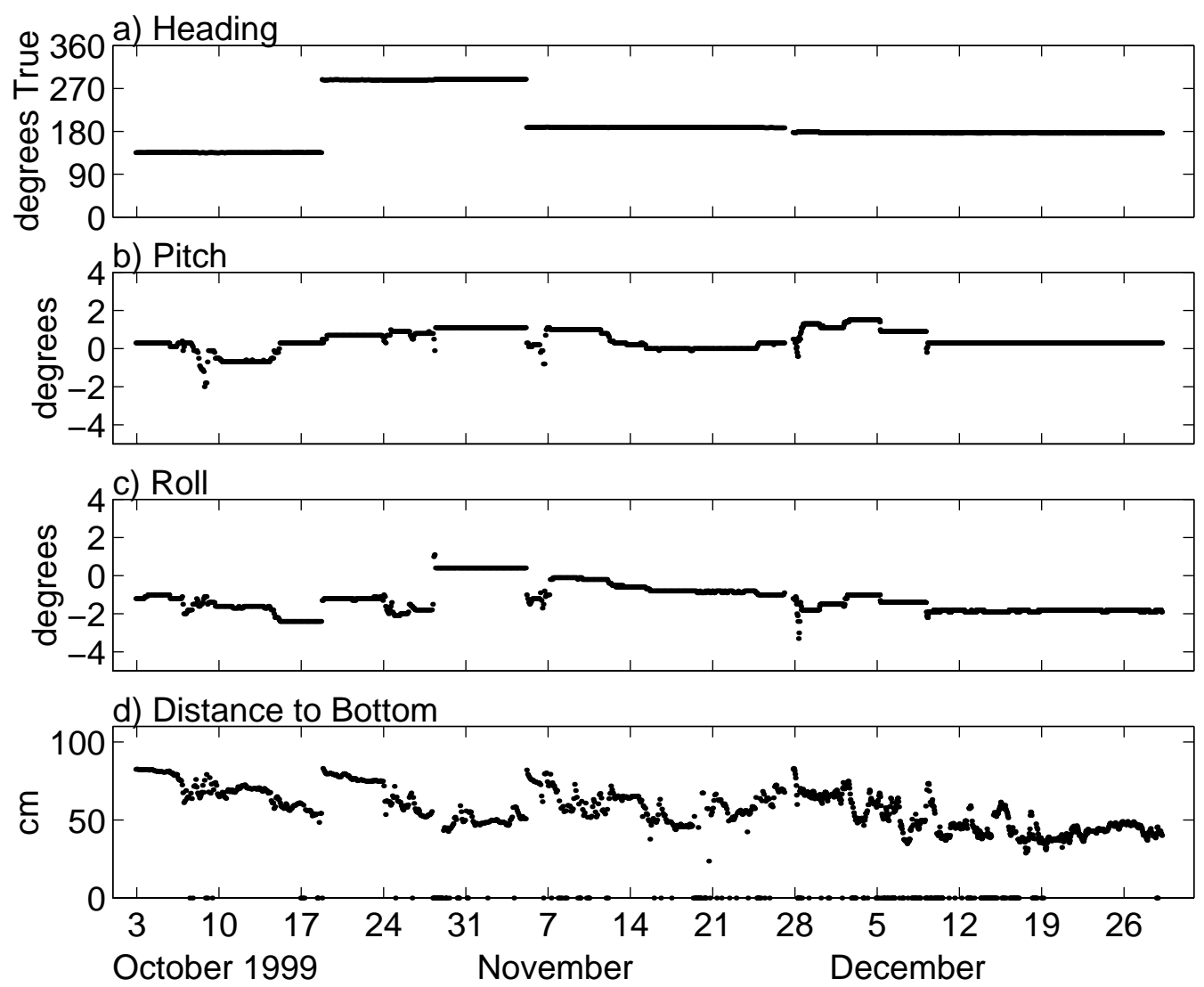

Figure 66. Time series of heading, pitch, roll, and distance to the bottom from data collected by the ADV at Site SS. 

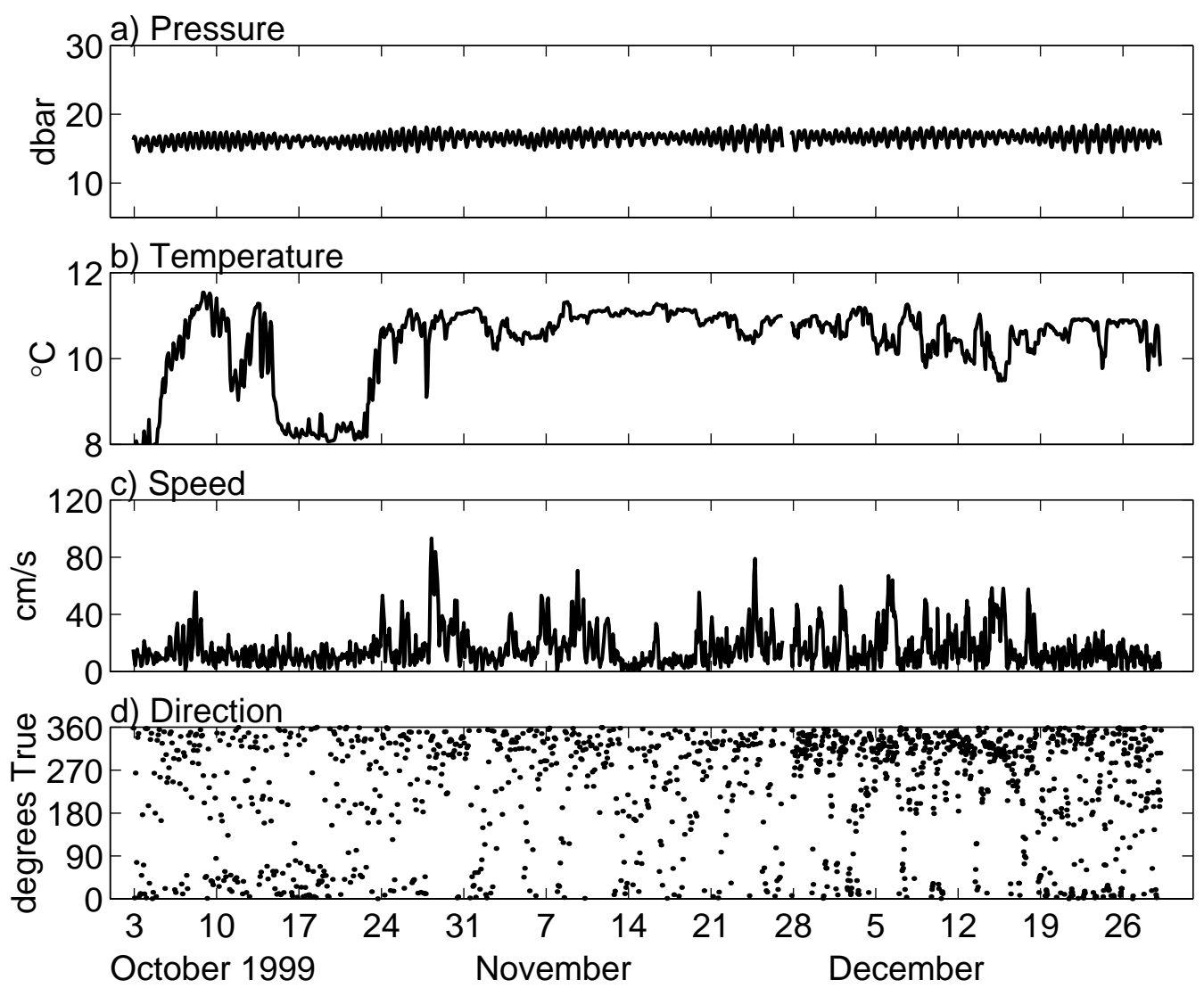

Figure 67. Time series of pressure, temperature, speed, and direction from data collected by the ADV at Site SS. 

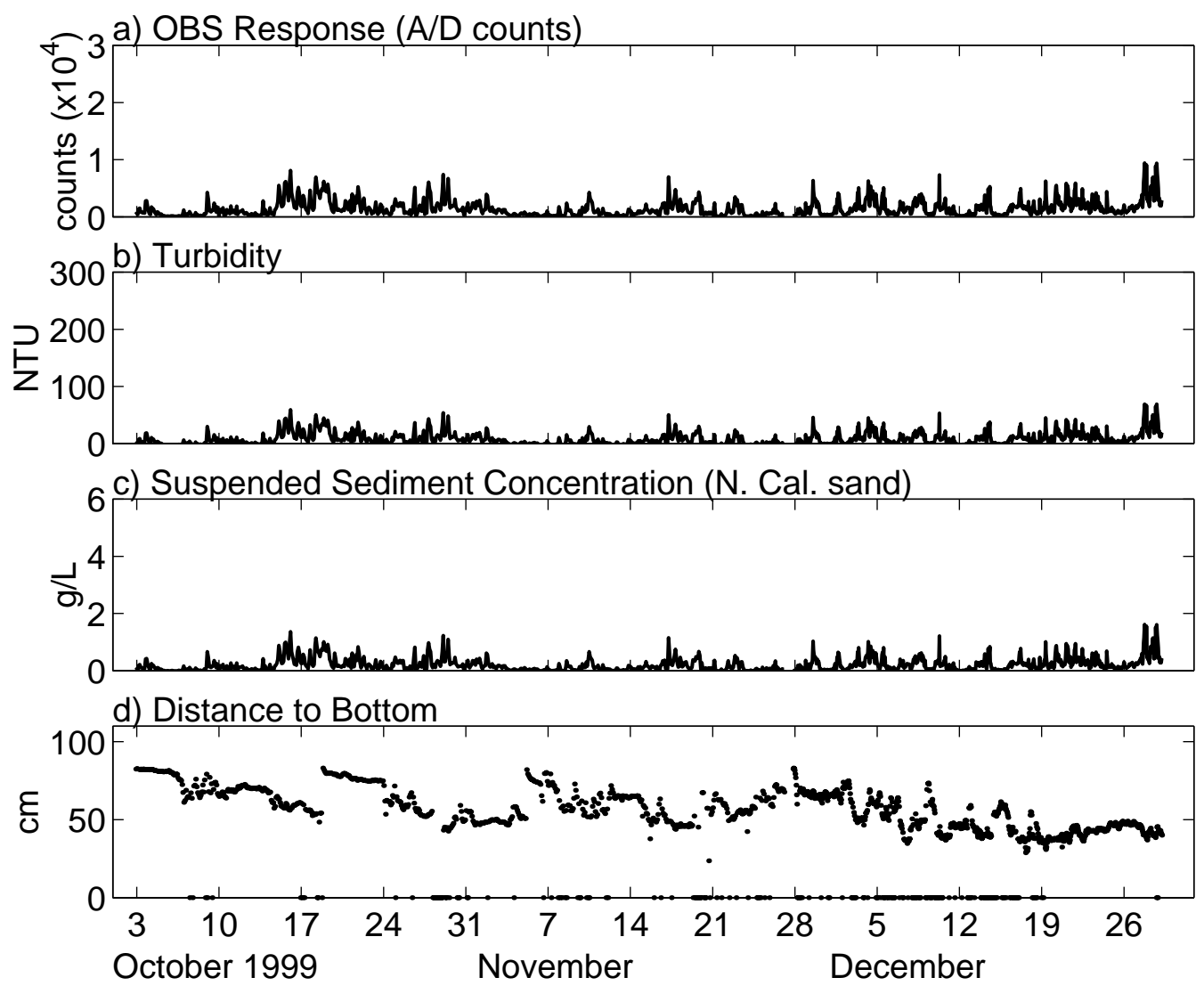

Figure 68. Time series of the response of the OBS, turbidity, suspended sediment concentration, and distance to the bottom for Site SS. 

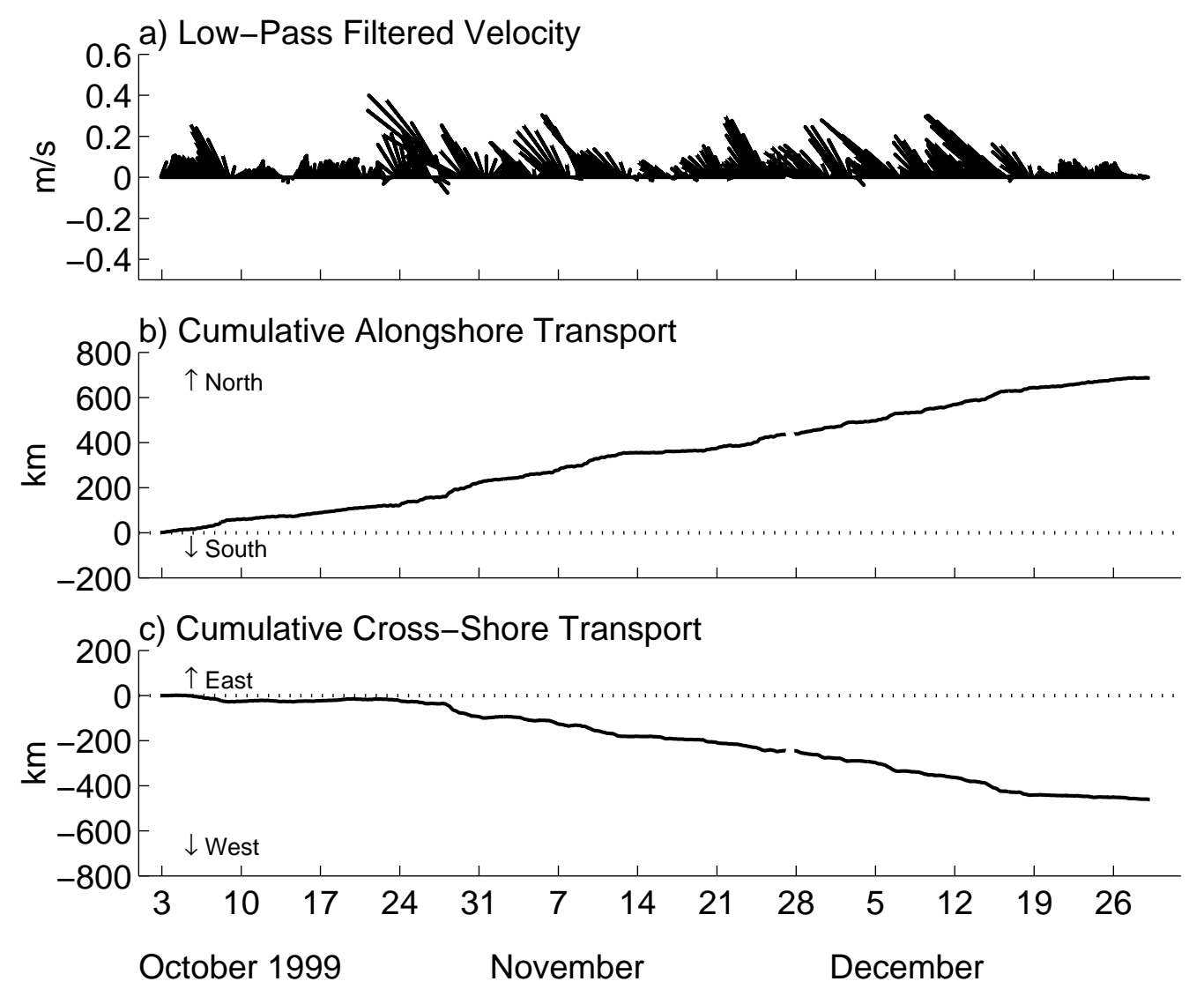

Figure 69. Time series of low-pass filtered velocity and cumulative alongshore and cross-shore transport for Site SS. 

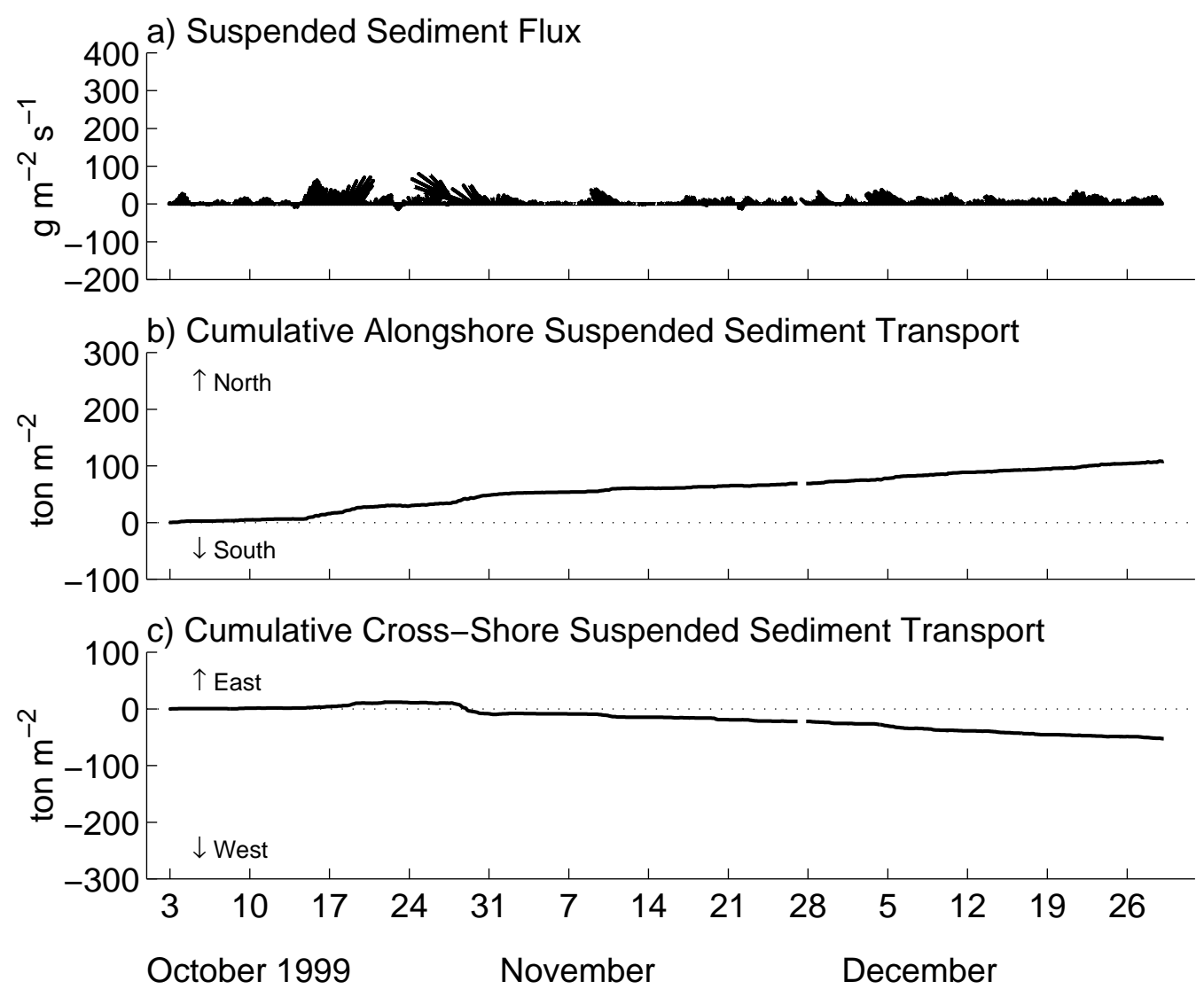

Figure 70. Time series of suspended sediment flux and cumulative alongshore and cross-shore suspended sediment transport for Site SS. 
a) Pressure

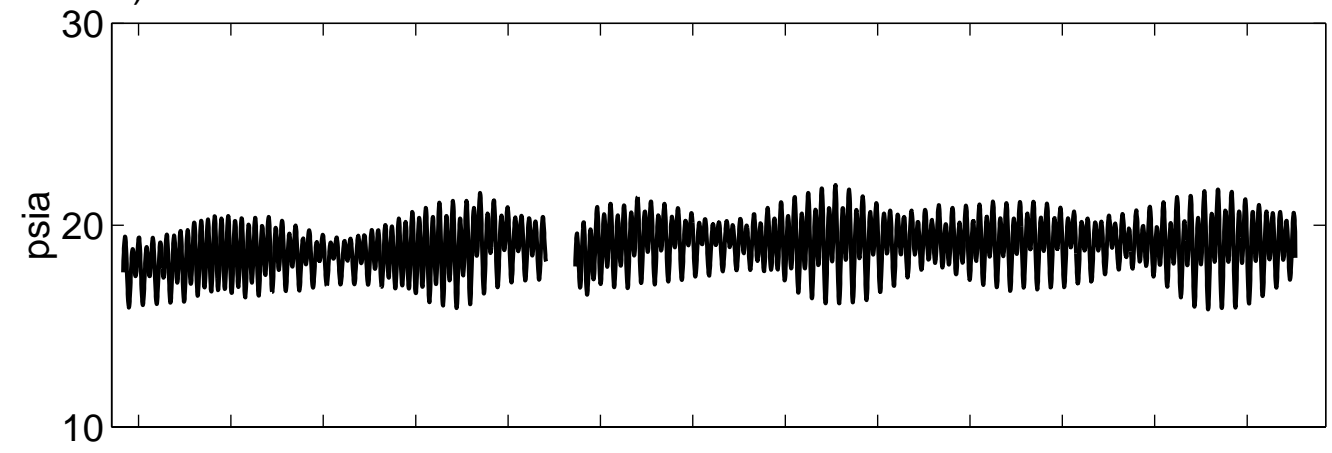

b) Temperature

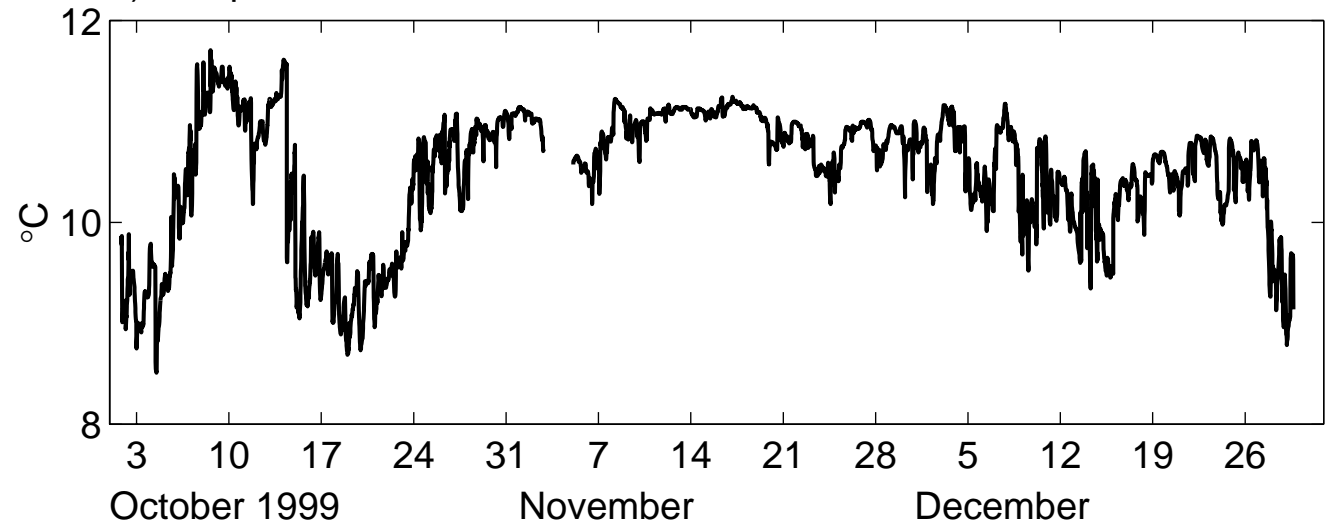

Figure 71 . Time series of pressure and temperature data collected by the Seagauge at Site MS.

Pressure and temperature data collected by the Seagauge at Site MS during both deployments are shown in Figure 71. The time has been adjusted to the center of the burst. Pressure data were adjusted by removing an approximate value for atmospheric pressure (14.75 psia). The bad data, determined as discussed at the beginning of Section 3.1, were removed from the record before plotting. 


\section{PRELIMINARY OBSERVATIONS FROM THE DATA}

The following preliminary observations can be made regarding the data collected during the Grays Harbor Wave Refraction Experiment:

1) On October 18, 1999 between 1618 and 1842 the tripod at Site SS was picked up and replaced by an unknown party. This can be seen in the change in heading from one burst to another(Figure 66). The tripod may have been replaced in a slightly different location.

2) The pressure sensor in the ADP at location SD was not working correctly at the beginning of Deployment 1 . It began working correctly at approximately 1600 October 8 , or before profile number 284.

3) Wave directions (not presented in this report) estimated from Site MD during the second deployment differ by about $16^{\circ}$ from the expected direction, suggesting the possibility of compass error or miscalibration.

4) The measured distance between the ADV sensor and the sea floor changed (and generally decreased) at all 5 ADV sites during each deployment, suggesting that the tripod was either being worked into the bed (more likely) or that net deposition of sediment occurred (less likely). Estimates of sensor elevation are particularly important for interpretation of current and suspended-sediment data from the ADV and associated OBS.

5) Table 12 lists the bursts which have been flagged as bad data points. This includes the beginning of the Deployment 1 ADP record at Site SD, when the pressure sensor was malfunctioning. Wave height data were flagged as bad if the significant wave height was larger than 10 meters. Wave period data were flagged as bad if the mean period exceeded 24 seconds or was less than or equal to 2 seconds. One data point was flagged as bad in the Deployment 2 ADV pressure record from Site SD for being greater than $50 \mathrm{dbar}$. This does not include points flagged as being out of the water (Table 11). It is noted which data records (pressure ( $p s)$, significant wave height $\left(H_{s}\right)$, mean period $\left.\left(T_{m}\right)\right)$ were affected. 


\section{REFERENCES}

Carver, R.E., 1971, Procedures in Sedimentary Petrology, New York, John Wiley and Sons, $653 \mathrm{pp}$.

D\&A Instrument Company, 1991, OBS-1 \& 3 Suspended Solids and Turbidity Monitor, Instruction Manual, Rev. 3/91, D\&A Instrument Co., Port Townsend, WA, 41 pp.

Folk, R. L., 1968, Petrology of Sedimentary Rocks, University of Texas Publication, Austin, 170 pp.

Folk, R.L., 1974, Petrology of Sedimentary Rocks, Hemphill Publishing Co., Austin, 182 pp.

Gelfenbaum, G., G. M. Kaminsky, C. R. Sherwood, and C. Peterson, Southwest Washington Coastal Erosion Workshop Report, 1997, U. S. Geological Survey Open-File Report 97471, $102 \mathrm{pp}$.

Gibbs, Ronald J., M. D. Matthews, and D. A. Link, 1971, The relationship between sphere size and settling velocity, Journal of Sedimentary Petrology, 41, no. 1, pp. 7-18.

Kaminsky, G. M., P. Ruggiero, G. Gelfenbaum, and C. Peterson, 1997, Long Term Coastal Evolution and Regional Dynamics of a U. S. Pacific Northwest Littoral Cell, Coastal Dynamics ‘97, pp. 614-623.

Sea-Bird Electronics, Inc., 2000a, SEACAT SBE 19 Conductivity, Temperature, Depth Recorder Operating Manual, Version 19.19, Sea-Bird Electronics Inc., Bellevue, WA, 43 pp.

Sea-Bird Electronics, Inc., 2000b, SBE 26 Seagauge Wave and Tide Recorder Operating Manual, Version 26.12, Sea-Bird Electronics Inc., Bellevue, WA, 54 pp.

SonTek Inc., 1998, ADP Software Manual, Version 5.4, October, 1998, SonTek Inc., San Diego, $\mathrm{CA}, 30 \mathrm{pp}$.

SonTek Inc., 1997, ADV Software Reference Manual, Version 4.0 (with updates for Version 7.1 ADV Software, November, 1999), June, 1997, SonTek Inc., San Diego, CA, 43 pp.

Syvitski, J.P.M., 1991, Principles, Methods, and Application of Particle Size Analysis, Cambridge University Press, $368 \mathrm{pp}$.

Thiede, J., T. Chriss, M. Clausson, and S. A. Swift, 1976, Settling Tubes for Size Analysis of Fine and Coarse Fractions of Oceanic Sediments, School of Oceanography, Oregon State University, Report \#76-8, 87 pp.

Tillotson, K., and P. Komar, 1997, The wave climate of the Pacific Northwest (Oregon and Washington): a comparison of data sources, Journal of Coastal Research, 13, no. 2, pp. $440 ` 452$.

Trask, P. D., 1930, Mechanical analysis of sediments by centrifuge, Economic Geology and the Bulletin of the Society of Economic Geologists, 25, no. 6, pp. 581-599.

Twichell, D. C., V. A. Cross, and K. F. Parolski, 2000, Sidescan-Sonar Imagery, Surface Sediment Samples, and Surficial Geologic Interpretation of the Southwestern Washington Inner Continental Shelf Based on Data Collected During Corliss Cruises 97007 and 98014, U.S. Geological Survey Open-File Report 00-167, 26 pp. 


\section{ACKNOWLEDGEMENTS}

This work was funded by the U.S. Geological Survey, Coastal and Marine Geology program as part of the joint USGS - Washington State Department of Ecology Southwest Washington Coastal Erosion Study. We thank Peter Howd, Kurt Hanson, and Meg Palmsten for their assistance in the pre-experiment numerical modeling and design of the field experiment, and skipper Terry Larson and the crew of the F/V Tricia Rae for successfully deploying and recovering the tripods. We especially thank Evans-Hamilton Inc., particularly Eric Noah and Justin Broderson, for their assistance in design, set-up, deployment, and recovery of the instrumented tripods. Their attention to detail was crucial to the success of this experiment. We would like to thank Daryl Slocum of SonTek, Inc. for his rapid response to our mid-deployment instrument failure. We also thank George Kaminsky for assisting in this field experiment and Holly Ryan for reviewing this manuscript. 


\section{APPENDIX A: FIELD LOGS}

This appendix summarizes the details recorded in field logs during the deployment and recovery of the tripods. 


\section{A.1 Deployment Log}

Table 14 summarizes the details of the first and second tripod deployments.

Table 14. Deployment field log.

\begin{tabular}{|c|c|c|c|c|c|c|c|c|c|c|c|c|}
\hline Site ID & ND & ND & NS & NS & MD & MD & MS & MS & SD & SD & SS & SS \\
\hline Deployment No. & 1 & 2 & 1 & 2 & 1 & 2 & 1 & 2 & 1 & 2 & 1 & 2 \\
\hline Date Deployed & $10 / 1 / 99$ & $11 / 5 / 99$ & $10 / 1 / 99$ & $11 / 5 / 99$ & $10 / 2 / 99$ & $11 / 27 / 99$ & $10 / 1 / 99$ & $11 / 5 / 99$ & $10 / 2 / 99$ & $11 / 27 / 99$ & $10 / 2 / 99$ & $11 / 27 / 99$ \\
\hline Aprx. Time Deployed (GMT) & 1937 & 0210 & 1900 & 0145 & 1953 & 2010 & 2055 & 0250 & 2040 & 1925 & 2057 & 1855 \\
\hline Latitude (N) & $47^{\circ} 00.768^{\prime}$ & $47^{\circ} 00.765^{\prime}$ & $47^{\circ} 00.841^{\prime}$ & $47^{\circ} 00.849^{\prime}$ & $46^{\circ} 57.059^{\prime}$ & $46^{\circ} 57.094^{\prime}$ & $46^{\circ} 56.853^{\prime}$ & $46^{\circ} 56.856^{\prime}$ & $46^{\circ} 52.411^{\prime}$ & $46^{\circ} 52.418^{\prime}$ & $46^{\circ} 53.507^{\prime}$ & $46^{\circ} 53.505^{\prime}$ \\
\hline Longitude (W) & $124^{\circ} 14.772^{\prime}$ & $124^{\circ} 14.790^{\prime}$ & $124^{\circ} 12.299^{\prime}$ & $124^{\circ} 12.302^{\prime}$ & $124^{\circ} 14.676^{\prime}$ & $124^{\circ} 14.687^{\prime}$ & $124^{\circ} 13.089^{\prime}$ & $124^{\circ} 13.098^{\prime}$ & $124^{\circ} 12.363^{\prime}$ & $124^{\circ} 12.353^{\prime}$ & $124^{\circ} 11.171^{\prime}$ & $124^{\circ} 11.200^{\prime}$ \\
\hline Aprx. Water Depth (m) & 22.92 & 24.41 & 10.82 & 16.92 & 22.28 & & 11.00 & 11.31 & 22.34 & & 13.23 & \\
\hline $\begin{array}{l}\text { Aprx. Dist. from Proposed } \\
\text { Position }(\mathrm{m})\end{array}$ & 6.10 & & 34.14 & & 27.13 & 82.30 & 3.35 & & 11.28 & 10.67 & 27.13 & 15.24 \\
\hline \multicolumn{13}{|l|}{ SonTek ADP System } \\
\hline ADP Serial No. & C134 & $\mathrm{C} 134$ & None & None & None & None & None & None & $\mathrm{C} 132$ & C132 & None & None \\
\hline ADP frequency $(\mathrm{kHz})$ & 1500 & 1500 & & & & & & & 1500 & 1500 & & \\
\hline Paros. Serial No. & None & None & & & & & & & None & None & & \\
\hline $\begin{array}{l}\text { Druck Press. Sens. } \\
\text { Installed? }\end{array}$ & Yes & Yes & & & & & & & Yes & Yes & & \\
\hline $\begin{array}{l}\text { Dist. from deck to top of } \\
\operatorname{ADP}(\mathrm{cm})\end{array}$ & & & & & & & & & 195.6 & 195.6 & & \\
\hline Command File Name & NDadpD1.cmd & NDadpD2.cmd & & & & & & & SDadpD1.cmd & SDadpD2.cmd & & \\
\hline Log File Name & NDadpD1d.log & NDadpD2d.log & & & & & & & SDadpD1d.log & SDadpD2d.log & & \\
\hline \multicolumn{13}{|c|}{ Hardware Configuration Parameters } \\
\hline Sensor Serial No. & C134 & C134 & & & & & & & C132 & $\mathrm{C} 132$ & & \\
\hline Sensor Type (kHz) & 1500 & 1500 & & & & & & & 1500 & 1500 & & \\
\hline Number of Beams & 3 & 3 & & & & & & & 3 & 3 & & \\
\hline Beam Geometry & 3 Beams & 3 Beams & & & & & & & 3 Beams & 3 Beams & & \\
\hline Slant Angle (deg) & 25.0 & 25.0 & & & & & & & 25 & 25 & & \\
\hline Orientation & UP & UP & & & & & & & UP & UP & & \\
\hline Compass/Tilt Sensor & YES & YES & & & & & & & YES & YES & & \\
\hline Recorder Sensor & YES & YES & & & & & & & YES & YES & & \\
\hline Temperature Sensor & YES & YES & & & & & & & YES & YES & & \\
\hline Pressure Sensor & NO & NO & & & & & & & NO & NO & & \\
\hline External Sensors & NO & NO & & & & & & & NO & NO & & \\
\hline External Pressure Sensor & DRUCK & DRUCK & & & & & & & DRUCK & DRUCK & & \\
\hline MicroCAT CTD & NO & NO & & & & & & & NO & NO & & \\
\hline Bottom Track Option & NO & NO & & & & & & & NO & NO & & \\
\hline
\end{tabular}


Table 14. Deployment field log. (Continued)

\begin{tabular}{|c|c|c|c|c|c|c|c|c|c|c|c|c|}
\hline $\begin{array}{l}\text { Site ID } \\
\text { Deployment No. }\end{array}$ & $\begin{array}{l}\text { ND } \\
1 \\
\end{array}$ & $\begin{array}{l}\text { ND } \\
2 \\
\end{array}$ & $\begin{array}{l}\text { NS } \\
1\end{array}$ & $\begin{array}{l}\text { NS } \\
2 \\
\end{array}$ & $\begin{array}{l}\mathrm{MD} \\
1 \\
\end{array}$ & $\begin{array}{l}\text { MD } \\
2 \\
\end{array}$ & $\begin{array}{l}\text { MS } \\
1 \\
\end{array}$ & $\begin{array}{l}\text { MS } \\
2 \\
\end{array}$ & $\begin{array}{l}\text { SD } \\
1 \\
\end{array}$ & $\begin{array}{l}\text { SD } \\
2 \\
\end{array}$ & $\begin{array}{l}\text { SS } \\
1 \\
\end{array}$ & $\begin{array}{l}\text { SS } \\
2\end{array}$ \\
\hline Waves Option & YES & YES & & & & & & & YES & YES & & \\
\hline \multicolumn{13}{|l|}{ ADPSystem Parameters } \\
\hline CPU Version - ADP & 6.1 & 6.1 & & & & & & & 6.1 & 6.1 & & \\
\hline DSP Version - DSP & 4.0 & 4.0 & & & & & & & 4.0 & 4.0 & & \\
\hline Board Rev. & D & D & & & & & & & D & D & & \\
\hline OutFormat & ASCII & ASCII & & & & & & & ASCII & ASCII & & \\
\hline OutMode & Auto & Auto & & & & & & & Auto & Auto & & \\
\hline Recorder & ON & ON & & & & & & & ON & ON & & \\
\hline RecMode & Normal & Normal & & & & & & & Normal & Normal & & \\
\hline BottomTrack & NO & NO & & & & & & & NO & NO & & \\
\hline \multicolumn{13}{|l|}{ ADP Setup Parameters } \\
\hline Temp (Deg C) & 20.0 & 20.0 & & & & & & & 20.0 & 20.0 & & \\
\hline Sal (PPT) & 34.0 & 34.0 & & & & & & & 34.0 & 34.0 & & \\
\hline TempMode & Measured & Measured & & & & & & & Measured & Measured & & \\
\hline Sound Speed $(\mathrm{m} / \mathrm{s})$ & 1520.3 & 1520.3 & & & & & & & 1520.3 & 1520.3 & & \\
\hline Cell Size $(m)$ & 0.50 & 0.50 & & & & & & & 0.50 & 0.50 & & \\
\hline Blank Distance $(\mathrm{m})$ & 0.40 & 0.40 & & & & & & & 0.40 & 0.40 & & \\
\hline $\mathrm{N}$ cells & 65 & 65 & & & & & & & 65 & 65 & & \\
\hline AvgInterval (s) & 900 & 900 & & & & & & & 900 & 900 & & \\
\hline Profile Interval (s) & 1800 & 1800 & & & & & & & 1800 & 1800 & & \\
\hline Ping Interval (s) & 0.0 & 0.0 & & & & & & & 0.0 & 0.0 & & \\
\hline CoordSystem & ENU & ENU & & & & & & & ENU & ENU & & \\
\hline \multicolumn{13}{|c|}{ ADP Deployment Parameters } \\
\hline Deployment & NDADP & NDADP & & & & & & & SDADP & SDADP & & \\
\hline Start Date & $10 / 1 / 99$ & $11 / 4 / 99$ & & & & & & & $10 / 299$ & $11 / 27 / 99$ & & \\
\hline Start Time (GMT) & $1752: 30$ & $1852: 30$ & & & & & & & $1852: 30$ & 2052:30 & & \\
\hline AvgInterval (s) & 900 & 900 & & & & & & & 900 & 900 & & \\
\hline Profile Interval (s) & 1800 & 1800 & & & & & & & 1800 & 1800 & & \\
\hline PingInterval (s) & 0.0 & 0.0 & & & & & & & 0.0 & 0.0 & & \\
\hline Burst Mode & Disabled & Disabled & & & & & & & Disabled & Disabled & & \\
\hline \multicolumn{13}{|c|}{ ADP Wave Sampling Parameters } \\
\hline $\begin{array}{l}\text { RecordPseries every } N \\
\text { profiles }\end{array}$ & 2 & 2 & & & & & & & 2 & 2 & & \\
\hline PseriesRate (Hz) & 2 & 2 & & & & & & & 2 & 2 & & \\
\hline PseriesLength (points) & 4096 & 4096 & & & & & & & 4096 & 4096 & & \\
\hline PseriesDuration (s) & 2048 & 2048 & & & & & & & 2048 & 2048 & & \\
\hline OutPseriesMode & Auto & Auto & & & & & & & Auto & Auto & & \\
\hline
\end{tabular}


Table 14. Deployment field log. (Continued)

\begin{tabular}{|c|c|c|c|c|c|c|c|c|c|c|c|c|}
\hline $\begin{array}{l}\text { Site ID } \\
\text { Deployment No. }\end{array}$ & $\begin{array}{l}\text { ND } \\
1\end{array}$ & $\begin{array}{l}\text { ND } \\
2\end{array}$ & $\begin{array}{l}\text { NS } \\
1\end{array}$ & $\begin{array}{l}\text { NS } \\
2\end{array}$ & $\begin{array}{l}\text { MD } \\
1\end{array}$ & $\begin{array}{l}\text { MD } \\
2\end{array}$ & $\begin{array}{l}\text { MS } \\
1\end{array}$ & $\begin{array}{l}\text { MS } \\
2\end{array}$ & $\begin{array}{l}\text { SD } \\
1\end{array}$ & $\begin{array}{l}\text { SD } \\
2\end{array}$ & $\begin{array}{l}\text { SS } \\
1\end{array}$ & $\begin{array}{l}\text { SS } \\
2\end{array}$ \\
\hline \multicolumn{13}{|l|}{ Deploy } \\
\hline Deployment File Name & NDadp001 & $\mathrm{NDac}$ & & & & & & & SDadp001 & SDadp004 & & \\
\hline $\begin{array}{l}\text { Deployment will start on } \\
\text { (Date) }\end{array}$ & $10 / 2 / 99$ & $11 / 5 /$ & & & & & & & 10/3/99 & $11 / 28 / 99$ & & \\
\hline $\begin{array}{l}\text { Deployment will start at } \\
\text { (Time - GMT) }\end{array}$ & 1752:30 & 1852 & & & & & & & 1852:30 & 2052:30 & & \\
\hline
\end{tabular}

\begin{tabular}{|c|c|c|c|c|c|c|c|c|c|c|c|}
\hline \multicolumn{12}{|l|}{ SonTek Hydra System } \\
\hline \multirow{3}{*}{$\begin{array}{l}\text { ADVOcean Serial No. } \\
\text { Battery Canister Serial No. } \\
\text { ("Brain Box") } \\
\text { Paros. Serial No. }\end{array}$} & B45 & B45 & B46 & B100 & B51 & None & \multirow[t]{2}{*}{ None } & B52 & B52 & \multirow{2}{*}{$\begin{array}{l}\text { B59 } \\
\text { None }\end{array}$} & \multirow{2}{*}{$\begin{array}{l}\text { B59 } \\
\text { None }\end{array}$} \\
\hline & None & None & None & G23 & None & None & & None & None & & \\
\hline & 66890 & 66890 & 69128 & None & 69130 & 69130 & & 69180 & 69180 & 69181 & 69181 \\
\hline $\begin{array}{l}\text { OBS Serial No. Installed on } \\
\text { Channel No. } 1\end{array}$ & 0795 & 0795 & 0928 & None & 1242 & 1242 & & 1243 & 1243 & 1244 & 1244 \\
\hline $\begin{array}{l}\text { Distance from deck to ADV- } \\
\text { Ocean Transmitter }(\mathrm{cm})\end{array}$ & 97.8 & 97.8 & 101.1 & 99.1 & 97.8 & 97.8 & & 97.8 & 97.8 & 98.4 & 98.4 \\
\hline $\begin{array}{l}\text { Distance from deck to } \\
\text { Paros. Pressure Port (cm) }\end{array}$ & 116.4 & 116.4 & & $\mathrm{~N} / \mathrm{A}$ & 116.8 & 116.8 & & 116.8 & 116.8 & 117.5 & 117.5 \\
\hline $\begin{array}{l}\text { Dist. from deck to OBS No. } \\
1(\mathrm{~cm})\end{array}$ & 79.1 & 79.1 & 81.3 & N/A & 78.1 & 78.1 & & 78.1 & 78.1 & 80.6 & 80.6 \\
\hline $\begin{array}{l}\text { Horizontal Dist. Between } \\
\text { ADV and Paros. }\end{array}$ & 17.1 & 17.1 & & $\mathrm{~N} / \mathrm{A}$ & 16.5 & 16.5 & & 15.2 & 15.2 & 15.2 & 15.2 \\
\hline Command File Name (.cmd) & NDadvD1.cmd & NDadvD2.cmd & NSadvD1.cmd & NSadvD2.cmd & MDadvD1.cmd & MDadvD2.cmd & & SDadvD1.cmd & SDadvD2.cmd & SSadvD1.cmd & SSadvD2.cmd \\
\hline Log File Name (.log) & NDadvD1d.log & NDadvD2d.log & NSadvD1d.log & NSadvD2d.log & MDadvD1d.log & MDadvD2d.log & & SDadvD1d.log & SDadvD2d.log & SSadvD1d.log & SSadvD2d.log \\
\hline \multicolumn{12}{|c|}{ Hardware Configuration Parameters } \\
\hline Probe Serial No. & B45B & B45B & B46B & B100B & B51B & B51B & & B52B & B52B & B59B & B59B \\
\hline Probe Type & Ocean Probe & Ocean Probe & Ocean Probe & Ocean Probe & Ocean Probe & Ocean Probe & & Ocean Probe & Ocean Probe & Ocean Probe & Ocean Probe \\
\hline Probe Orientation & DOWN & DOWN & DOWN & DOWN & DOWN & DOWN & & DOWN & DOWN & DOWN & DOWN \\
\hline Compass Sensor & YES & YES & YES & YES & YES & YES & & YES & YES & YES & YES \\
\hline Recorder Sensor & YES & YES & YES & YES & YES & YES & & YES & YES & YES & YES \\
\hline Temperature Sensor & YES & YES & YES & YES & YES & YES & & YES & YES & YES & YES \\
\hline Pressure Sensor & NO & NO & NO & YES & NO & NO & & NO & NO & NO & NO \\
\hline External Pressure Sensor & PAROS & PAROS & PAROS & NO & PAROS & PAROS & & PAROS & PAROS & PAROS & PAROS \\
\hline External Sensors & YES & YES & YES & NO & YES & YES & & YES & YES & YES & YES \\
\hline MicroCAT CTD & NO & NO & NO & NO & NO & NO & & NO & NO & NO & NO \\
\hline \multicolumn{12}{|l|}{ ADVSystem Parameters } \\
\hline CPU Version - ADV & 7.0 & 7.0 & 7.0 & 7.0 & 7.0 & 7.0 & & 7.0 & 7.0 & 7.0 & 7.0 \\
\hline DSP Version - DSP & 4.0 & 4.0 & 4.0 & 4.0 & 4.0 & 4.0 & & 4.0 & 4.0 & 4.0 & 4.0 \\
\hline Board Rev. & $\mathrm{D}$ & $\mathrm{D}$ & $\mathrm{D}$ & $\mathrm{D}$ & D & D & & $\mathrm{D}$ & $\mathrm{D}$ & $\mathrm{D}$ & $\mathrm{D}$ \\
\hline OutFormat & ASCII & ASCII & ASCII & ASCII & ASCII & ASCII & & ASCII & ASCII & ASCII & ASCII \\
\hline OutMode & Auto & Auto & Auto & Auto & Auto & Auto & & Auto & Auto & Auto & Auto \\
\hline
\end{tabular}


Table 14. Deployment field log. (Continued)

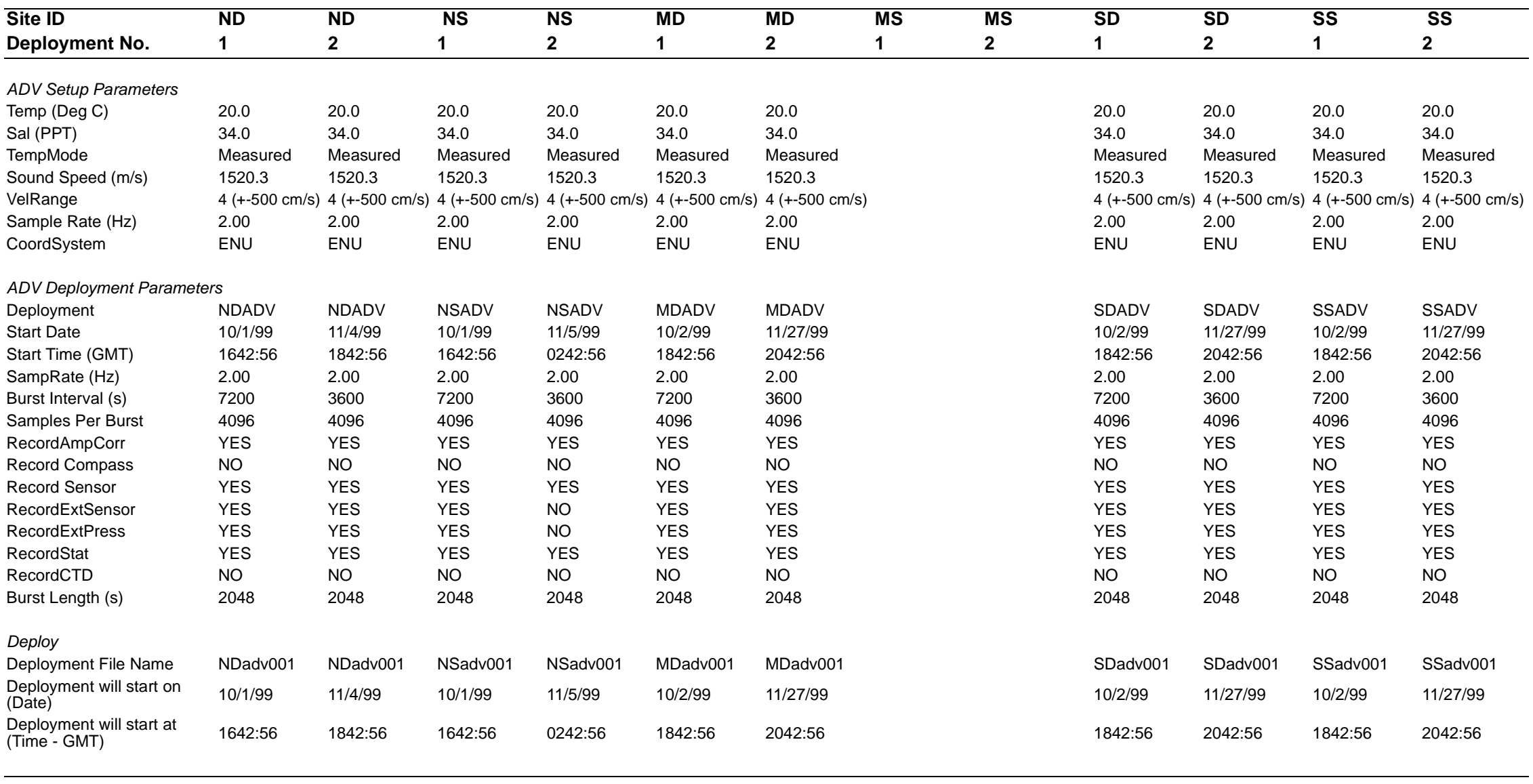


Table 14. Deployment field log. (Continued)

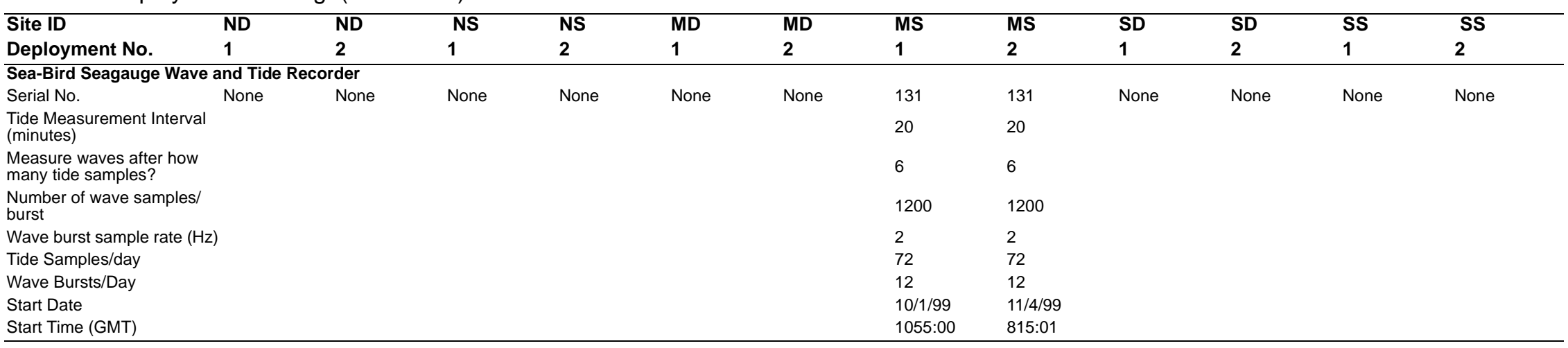




\section{A.2 Recovery Log}

The following field notes were recorded during recovery operations.

\section{A.2.1 Observations Made Upon Recovery of Tripods after Deployment 1}

ND: The tripod at Site ND pulled out of the water easier than those at Sites NS and MD. Algae were present on the battery canisters, the rope can, the tripod, the ADV (including arm), the Paros, the data logger, and the ADP (including sensors). There was seaweed on the cables and the ADV. There was oxidation on the battery canisters and sediment in the rope canister.

NS: The tripod at Site NS was difficult to pull off the bottom. The rope can had fallen off and the rope was tangled all over the tripod. The bar holding the OBS was bent outward towards the closest tripod leg. One probe arm (the one opposite the Benthos and closest to the batter canister) on the ADV was bent approximately $45^{\circ}$ upward. The Benthos buoy was extremely banged up with deep gouges in it. All 4 data logger corners were abraded on the cable input side, possibly from electronic corrosion. The aluminum of the tripod around the data logger was "discolored". It looked cleaner, similar to before it went in the water. One connection to the data logger had exposed copper between the logger and the plastic connector. Gastropods have been living in this area on both connectors. Gastropods were also found on the ADV cable connectors and on the tripod itself. Algae had collected on the data logger and on the tripod. Shells had collected behind the ADV. Large rocks $(5-6 \mathrm{~cm})$ were found laying on the tripod and inside the upper and lower cross bars. Shells and large sand dollars $(5-6 \mathrm{~cm})$ were packed in two corners (the sides opposite the bent ADV arm). This may have been from tilting on the way up. Approximately one minute after being placed on deck, one leg "burst" with sand and water shooting out of the foot of the tripod.

MD: The tripod at Site MD was hard to pull off the bottom. It was hard to tell how far it had been buried. The rope canister was ripped off upon retrieval. The tripod looked to be in great condition. The transducers on the Hydra system were clean.

MS: The tripod at Site MS was a little difficult to pull off the bottom. The bottom crossbars showed no algae growing on them suggesting that they may have been buried. The Sea-Bird Seagauge did have algae growing on it suggesting that it was not buried. Seaweed was present on the line from the buoy to rope canister and around the Benthos and Seagauge safeties. The rope from the top of tripod to the main buoy was slightly frayed at the shackle. Small barnacles were present on the rope canister. Seaweed and small barnacles were on the hose clamps holding the Benthos on the tripod. There were algae on the pinger, the Seagauge, the ropes and the tripod. A loop of rope had come out from the top of the rope canister and was wrapped around the exposed rope extending from the Benthos to the bottom of the rope canister.

SD: The tripod at Site SD was hard to pull off the bottom. It was buried approximately $0.5 \mathrm{~m}$. The tripod appeared to be in excellent condition. The Paros and rope canister were sheared off during retrieval. The surface buoy line nearly broke (one strand cut). The ADP was in good condition except the paint was peeling a little. The transducers on the Hydra system were clean.

SS: The tripod at Site SS came up easily and in very good condition. A little brown algae was on the Hydra system. Specifically, it was present on the ADV transducer and on the Paros. The rope canister was probably ok but was sheared off upon retrieval.

\section{A.2.2 Observations Made Upon Recovery of Tripods after Deployment 2}

ND: The tripod at Site ND appeared to have taken a hit. One hose clamp on the ADV and one on the Paros were broken. No damage was visible. 
NS: The tripod at Site NS was stuck on the bottom. It was believed that 2 legs were buried roughly 0.6 meters in the sand. It appeared to be in good condition once on deck.

MD: The tripod at Site MD appeared to be in good condition once on deck.

MS: The tripod at Site MS was only slightly stuck on the bottom. Tripod appeared to be in good condition once on deck.

SD: The tripod at Site SD was in good condition. The pins on the Paros connector broke easily while unconnecting the instrument.

SS: The tripod at Site SS was in good condition and only slightly stuck. The pins on the Paros connector broke easily while unconnecting the instrument. 


\section{APPENDIX B: DESCRIPTION OF FILES ON CD-ROMS AND CONTENTS OF COMPRESSED FILES}

Tables 15 through 32 summarize the contents of the CD-roms that accompany this open-file report.

Table 15. Description of Files on CD01.

\begin{tabular}{|c|c|c|c|}
\hline Site & Filename & Contents of File & File Size \\
\hline & 1_README.TXT & CD information and instructions & $3 \mathrm{~KB}$ \\
\hline & OF00-404.pdf & PDF version of paper report & $21 \mathrm{~KB}$ \\
\hline & index.htm & HTML page with links to data files & $7 \mathrm{~KB}$ \\
\hline & site_map.htm & index.htm support file & $2 \mathrm{~KB}$ \\
\hline & on-cd01.htm & index.htm support file & $1 \mathrm{~KB}$ \\
\hline & on-cd02.htm & index.htm support file & $1 \mathrm{~KB}$ \\
\hline & on-cd03.htm & index.htm support file & $1 \mathrm{~KB}$ \\
\hline & dep_tabl.htm & index.htm support file & $21 \mathrm{~KB}$ \\
\hline & cdconttb.htm & index.htm support file & $23 \mathrm{~KB}$ \\
\hline & banner.jpg & index.htm support file & $30 \mathrm{~KB}$ \\
\hline & gh_site.gif & index.htm support file & $116 \mathrm{~KB}$ \\
\hline & deptb_sm.jpg & index.htm support file & $3 \mathrm{~KB}$ \\
\hline & deptb_sm.png & index.htm support file & $8 \mathrm{~KB}$ \\
\hline & ofcvr_sm.gif & index.htm support file & $4 \mathrm{~KB}$ \\
\hline & ghst_sm.gif & index.htm support file & $6 \mathrm{~KB}$ \\
\hline \multirow[t]{8}{*}{ ND } & nd01/nd01adp.txt & Directory of ASCII ADP Data & $1 \mathrm{~KB}$ \\
\hline & nd01/nd01adp.zip & ADP data converted to ASCII files - zipped & $8 \mathrm{MB}$ \\
\hline & nd02/nd02adp.txt & Directory of ASCII ADP Data & $2 \mathrm{~KB}$ \\
\hline & nd02/nd02adp.zip & ADP data converted to ASCII files- zipped & $14 \mathrm{MB}$ \\
\hline & nd01/nd01adv.txt & Directory of ASCII ADV Data & $1 \mathrm{~KB}$ \\
\hline & nd01/nd01adv.zip & $\begin{array}{l}\text { Acoustic doppler velocimeter (ADV) data converted to ASCII files - } \\
\text { zipped }\end{array}$ & $36 \mathrm{MB}$ \\
\hline & nd02/nd02adv.txt & Directory of ASCII ADV Data & $1 \mathrm{~KB}$ \\
\hline & nd02/nd02adv.zip & $\begin{array}{l}\text { Acoustic doppler velocimeter (ADV) data converted to ASCII files - } \\
\text { zipped }\end{array}$ & $90 \mathrm{MB}$ \\
\hline \multirow[t]{2}{*}{ NS } & ns02/ns02adv.txt & Directory of ASCII ADV Data & $1 \mathrm{~KB}$ \\
\hline & ns02/ns02adv.zip & ASCII ADV Data - zipped & $111 \mathrm{MB}$ \\
\hline
\end{tabular}


Table 16. Description of files on CD02.

\begin{tabular}{|c|c|c|c|}
\hline Site & Filename & Contents of File & File Size \\
\hline & index.htm & HTML page with links to data files & $7 \mathrm{~KB}$ \\
\hline & site_map.htm & index.htm support file & $2 \mathrm{~KB}$ \\
\hline & on-cd01.htm & index.htm support file & $1 \mathrm{~KB}$ \\
\hline & on-cd02.htm & index.htm support file & $1 \mathrm{~KB}$ \\
\hline & on-cd03.htm & index.htm support file & $1 \mathrm{~KB}$ \\
\hline & dep_tabl.htm & index.htm support file & $21 \mathrm{~KB}$ \\
\hline & cdconttb.htm & index.htm support file & $23 \mathrm{~KB}$ \\
\hline & banner.jpg & index.htm support file & $30 \mathrm{~KB}$ \\
\hline & gh_site.gif & index.htm support file & $116 \mathrm{~KB}$ \\
\hline & deptb_sm.jpg & index.htm support file & $3 \mathrm{~KB}$ \\
\hline & deptb_sm.png & index.htm support file & $8 \mathrm{~KB}$ \\
\hline & ofcvr_sm.gif & index.htm support file & $4 \mathrm{~KB}$ \\
\hline & ghst_sm.gif & index.htm support file & $6 \mathrm{~KB}$ \\
\hline \multirow[t]{4}{*}{ MD } & md01/md01adv.txt & Directory of ASCII ADV Data & $1 \mathrm{~KB}$ \\
\hline & md01/md01adv.zip & ASCII ADV Data - zipped & $63 \mathrm{MB}$ \\
\hline & md02/md02adv.txt & Directory of ASCII ADV Data & $1 \mathrm{~KB}$ \\
\hline & md02/md02adv.zip & ASCII ADV Data - zipped & $75 \mathrm{MB}$ \\
\hline \multirow[t]{4}{*}{ MS } & $\mathrm{ms} 01 / \mathrm{ms} 01 \mathrm{sb} . \mathrm{txt}$ & Directory of ASCII Seaguage data & $1 \mathrm{~KB}$ \\
\hline & ms01/ms01sb.zip & ASCII Seaguage data - zipped & $4 \mathrm{MB}$ \\
\hline & ms02/ms02sb.txt & Directory of ASCII Seaguage data & $1 \mathrm{~KB}$ \\
\hline & ms02/ms01sb.zip & ASCII Seaguage data - zipped & $6 \mathrm{MB}$ \\
\hline \multirow[t]{8}{*}{ SD } & sd01/sd01adp.txt & Directory of ASCII ADP data & $2 \mathrm{~KB}$ \\
\hline & sd01/sd01adp.zip & ADP data converted to ASCII files - zipped & $20 \mathrm{MB}$ \\
\hline & sd02/sd02adp.txt & Directory of ASCII ADP data & $1 \mathrm{~KB}$ \\
\hline & sd02/sd02adp.zip & ADP data converted to ASCII files - zipped & $8 \mathrm{MB}$ \\
\hline & sd01/sd01adv.txt & Directory of ASCII ADV data & $1 \mathrm{~KB}$ \\
\hline & sd01/sd01adv.zip & ADV data converted to ASCII files - zipped & $62 \mathrm{MB}$ \\
\hline & sd02/sd02adv.txt & Directory of ASCII ADV data & $1 \mathrm{~KB}$ \\
\hline & sd02/sd02adv.zip & ADV data converted to ASCII files - zipped & $74 \mathrm{MB}$ \\
\hline \multirow[t]{4}{*}{ SS } & ss01/ss01adv.txt & Directory of ASCII ADV data & $1 \mathrm{~KB}$ \\
\hline & ss01/ss01adv.zip & ADV data converted to ASCII files - zipped & $64 \mathrm{MB}$ \\
\hline & ss02/ss02adv.tx & Directory of ASCII ADV data & $1 \mathrm{~KB}$ \\
\hline & ss02/ss02adv.zip & ADV data converted to ASCII files - zipped & $75 \mathrm{MB}$ \\
\hline
\end{tabular}


Table 17. Description of files on CD03.

\begin{tabular}{|c|c|c|c|}
\hline Site & Filename & Contents of File & File Size \\
\hline & index.htm & HTML page with links to data files & $7 \mathrm{~KB}$ \\
\hline & site_map.htm & index.htm support file & $2 \mathrm{~KB}$ \\
\hline & on-cd01.htm & index.htm support file & $1 \mathrm{~KB}$ \\
\hline & on-cd02.htm & index.htm support file & $1 \mathrm{~KB}$ \\
\hline & on-cd03.htm & index.htm support file & $1 \mathrm{~KB}$ \\
\hline & dep_tabl.htm & index.htm support file & $21 \mathrm{~KB}$ \\
\hline & cdconttb.htm & index.htm support file & $23 \mathrm{~KB}$ \\
\hline & banner.jpg & index.htm support file & $30 \mathrm{~KB}$ \\
\hline & gh_site.gif & index.htm support file & $116 \mathrm{~KB}$ \\
\hline & deptb_sm.jpg & index.htm support file & $3 \mathrm{~KB}$ \\
\hline & deptb_sm.png & index.htm support file & $8 \mathrm{~KB}$ \\
\hline & ofcvr_sm.gif & index.htm support file & $4 \mathrm{~KB}$ \\
\hline & ghst_sm.gif & index.htm support file & $6 \mathrm{~KB}$ \\
\hline \multirow[t]{5}{*}{ ND } & ndadpd01.adp & $\begin{array}{l}\text { Binary acoustic doppler velocimeter (ADP) data, which can only be } \\
\text { read with custom software (i.e. SonTek's ViewADP) and must be } \\
\text { accompanied by the Druck pressure sensor calibration data }\end{array}$ & $11 \mathrm{MB}$ \\
\hline & ndadpd02.adp & Binary ADP data & $19 \mathrm{MB}$ \\
\hline & 958200.drk & Druck pressure sensor calibration data & $1 \mathrm{~KB}$ \\
\hline & ndadvd01.adr & $\begin{array}{l}\text { Binary Acoustic Doppler Velocimeter (ADV) Data, which can only be } \\
\text { read with custom software (i.e. SonTek's gadvhdr) }\end{array}$ & $37 \mathrm{MB}$ \\
\hline & ndadvd02.adr & Binary ADV Data & $84 \mathrm{MB}$ \\
\hline NS & nsadvd02.adr & Binary ADV Data & $84 \mathrm{MB}$ \\
\hline \multirow[t]{2}{*}{ MD } & mdadvd01.adr & Binary ADV Data & $63 \mathrm{MB}$ \\
\hline & mdadvd02.adr & Binary ADV Data & $72 \mathrm{MB}$ \\
\hline \multirow[t]{5}{*}{ SD } & sdadpd01.adp & Binary ADP data & $19 \mathrm{MB}$ \\
\hline & sdadpd02.adp & Binary ADP data & $11 \mathrm{MB}$ \\
\hline & 995410.drk & Druck pressure sensor calibration data & $1 \mathrm{~KB}$ \\
\hline & sdadvd01.adr & Binary ADV Data & $63 \mathrm{MB}$ \\
\hline & sdadvd02.adr & Binary ADV Data & $71 \mathrm{MB}$ \\
\hline \multirow[t]{2}{*}{ SS } & ssadvd01.adr & Binary ADV Data & $63 \mathrm{MB}$ \\
\hline & ssadvd02.adr & Binary ADV Data & $71 \mathrm{MB}$ \\
\hline
\end{tabular}


Table 18. Contents of ndadp01.zip, zipped ADP data converted to ASCIl files, Site ND Deployment 1.

\begin{tabular}{|c|c|c|c|}
\hline Filename & Description of Contents & File Size & $\begin{array}{l}\text { Packed } \\
\text { File Size }\end{array}$ \\
\hline adp-a-fmt.txt & Details column headers for .a1/.a2/.a3 files & 178 & 140 \\
\hline adp-hdr-fmt.txt & Details column headers for .hdr file & 977 & 343 \\
\hline adp-pts-fmt.txt & Details column headers for .pts file & 172 & 134 \\
\hline adp-sd-fmt.txt & Details column headers for .sd1/.sd2/.sd3 files & 198 & 160 \\
\hline adp-sn-fmt.txt & Details column headers for .sn1/.sn2/.sn3 files & 188 & 146 \\
\hline adp-ve-fmt.txt & Details column headers for ve file & 187 & 147 \\
\hline adp-vn-fmt.txt & Details column headers for .vn file & 184 & 148 \\
\hline adp-vu-fmt.txt & Details column headers for vu file & 191 & 151 \\
\hline adp-wav-fmt.txt & Details column headers for wav file & 821 & 249 \\
\hline ndadpd01.a1 & Amplitude of signal strength for beam 1 & 514,932 & 75,296 \\
\hline ndadpd01.a2 & Amplitude of signal strength for beam 2 & 514,932 & 75,248 \\
\hline ndadpd01.a3 & Amplitude of signal strength for beam 3 & 514,932 & 74,519 \\
\hline ndadpd01.ctl & ADP control file - details sampling scheme and instrument setup & 3,864 & 1,320 \\
\hline ndadpd01.hdr & Header data & 187,671 & 27,313 \\
\hline ndadpd01.pts & Pressure time series data & $34,521,600$ & $6,937,523$ \\
\hline ndadpd01.sd1 & Standard deviation of east (magnetic) component of velocity & 615,747 & 65,644 \\
\hline ndadpd01.sd2 & Standard deviation of north (magnetic) component of velocity & 615,747 & 69,289 \\
\hline ndadpd01.sd3 & Standard deviation of vertical component of velocity & 615,747 & 36,022 \\
\hline ndadpd01.sn1 & Signal to noise ratio for beam 1 & 615,747 & 73,614 \\
\hline ndadpd01.sn2 & Signal to noise ratio for beam 2 & 615,747 & 73,943 \\
\hline ndadpd01.sn3 & Signal to noise ratio for beam 3 & 615,747 & 72,842 \\
\hline ndadpd01.ve & East (magnetic) component of velocity & 817,377 & 186,429 \\
\hline ndadpd01.vn & North (magnetic) component of velocity & 817,377 & 191,034 \\
\hline ndadpd01.vu & Vertical (up positive) component of velocity & 817,377 & 139,450 \\
\hline ndadpd01.wav & Wave data & 82,150 & 18,903 \\
\hline 25 file(s) & & $42,489,790$ & $8,120,007$ \\
\hline
\end{tabular}

Table 19. Contents of ndadv01.zip, zipped ADV data converted to ASCII files, Site ND Deployment 1.

\begin{tabular}{llll}
\hline Name & Description of Contents & File Size & $\begin{array}{l}\text { Packed } \\
\text { File Size }\end{array}$ \\
\hline adv-hdr-fmt.txt & Details column headers of .hdr file & 2,262 & 659 \\
adv-ts-fmt.txt & Details column header of .ts file & 605 & 285 \\
ndadvd01.ctl & ADV control file - details sampling scheme and instrument setup & 2,456 & 856 \\
ndadvd01.hdr & Header data & 121,757 & 25,840 \\
ndadvd01.ts & Time series data & $159,334,400$ & $36,199,359$ \\
\hline 5 file(s) & & $159,461,480$ & $36,226,999$ \\
\hline
\end{tabular}


Table 20. Contents of mdadv01.zip, zipped ADV data converted to ASCII files, Site MD Deployment 1.

\begin{tabular}{llll}
\hline Name & Description of Contents & File Size & $\begin{array}{l}\text { Packed File } \\
\text { Size }\end{array}$ \\
\hline adv-hdr-fmt.txt & Details column headers of .hdr file & 2,262 & 659 \\
adv-ts-fmt.txt & Details column header of .ts file & 605 & 285 \\
mdadvd01.ctl & ADV control file - details sampling scheme and instrument setup & 2,456 & 861 \\
mdadvd01.hdr & Header data & 208,458 & 44,341 \\
mdadvd01.ts & Time series data & $272,793,600$ & $62,846,272$ \\
\hline 5 file(s) & & $273,007,381$ & $62,892,418$ \\
\hline
\end{tabular}

Table 21. Contents of mssb01.zip, zipped Seagauge data converted to ASCIl files, Site MS Deployment 1.

\begin{tabular}{llll}
\hline \multirow{2}{*}{ Name } & Description of Contents & File Size & $\begin{array}{l}\text { Packed File } \\
\text { Size }\end{array}$ \\
\hline mstidd1.hex & Raw Seagauge ASCll data file & $3,211,623$ & $1,437,580$ \\
mstidd1.tid & Tide data & 115,297 & 24,809 \\
mstidd1.wb & Wave burst data & $7,187,210$ & $2,054,624$ \\
sb-tid-fmt.txt & Details column headers of .tid file & 280 & 191 \\
sb-wb-fmt.txt & Details column headers of .wb file & 524 & 307 \\
\hline 5 file(s) & & $10,514,934$ & $3,517,511$ \\
\hline
\end{tabular}


Table 22. Contents of sdadp01.zip, zipped ADP data converted to ASCIl files, Site SD Deployment 1.

\begin{tabular}{|c|c|c|c|}
\hline Filename & Description of Contents & File Size & $\begin{array}{l}\text { Packed } \\
\text { File Size }\end{array}$ \\
\hline adp-a-fmt.txt & Details column headers for .a1/.a2/.a3 files & 178 & 140 \\
\hline adp-hdr-fmt.txt & Details column headers for .hdr file & 977 & 343 \\
\hline adp-pts-fmt.txt & Details column headers for .pts file & 172 & 134 \\
\hline adp-sd-fmt.txt & Details column headers for .sd1/.sd2/.sd3 files & 198 & 160 \\
\hline adp-sn-fmt.txt & Details column headers for .sn1/.sn2/.sn3 files & 188 & 146 \\
\hline adp-ve-fmt.txt & Details column headers for .ve file & 187 & 147 \\
\hline adp-vn-fmt.txt & Details column headers for .vn file & 184 & 148 \\
\hline adp-vu-fmt.txt & Details column headers for .vu file & 191 & 151 \\
\hline adp-wav-fmt.txt & Details column headers for wav file & 821 & 249 \\
\hline sdadpd01.a1 & Amplitude of signal strength for beam 1 & 884,116 & 120,509 \\
\hline sdadpd01.a2 & Amplitude of signal strength for beam 2 & 884,116 & 125,011 \\
\hline sdadpd01.a3 & Amplitude of signal strength for beam 3 & 884,116 & 120,636 \\
\hline sdadpd01.ctl & ADP control file - details sampling scheme and instrument setup & 3,865 & 1,321 \\
\hline sdadpd01.hdr & Header data & 322,223 & 45,529 \\
\hline sdadpd01.pts & Pressure time series data & $59,288,064$ & $17,454,022$ \\
\hline sdadpd01.sd1 & Standard deviation of east (magnetic) component of velocity & $1,057,211$ & 138,644 \\
\hline sdadpd01.sd2 & Standard deviation of north (magnetic) component of velocity & $1,057,211$ & 146,555 \\
\hline sdadpd01.sd3 & Standard deviation of vertical component of velocity & $1,057,211$ & 83,178 \\
\hline sdadpd01.sn1 & Signal to noise ratio for beam 1 & $1,057,211$ & 116,590 \\
\hline sdadpd01.sn2 & Signal to noise ratio for beam 2 & $1,057,211$ & 121,955 \\
\hline sdadpd01.sn3 & Signal to noise ratio for beam 3 & $1,057,211$ & 113,205 \\
\hline sdadpd01.ve & East (magnetic) component of velocity & $1,403,401$ & 339,042 \\
\hline sdadpd01.vn & North (magnetic) component of velocity & $1,403,401$ & 339,522 \\
\hline sdadpd01.vu & Vertical (up positive) component of velocity & $1,403,401$ & 271,421 \\
\hline Sdadpd01.wav & Wave data & 142,417 & 15,804 \\
\hline 25 file(s) & & $72,965,482$ & $19,554,562$ \\
\hline
\end{tabular}

Table 23. Contents of sdadv01.zip, zipped ADV data converted to ASCII files, Site SD Deployment 1.

\begin{tabular}{llll}
\hline Name & Description of Contents & File Size & $\begin{array}{l}\text { Packed File } \\
\text { Size }\end{array}$ \\
\hline adv-hdr-fmt.txt & Details column headers of .hdr file & 2,262 & 659 \\
adv-ts-fmt.txt & Details column header of .ts file & 605 & 285 \\
sdadvd01.ctl & ADV control file - details sampling scheme and instrument setup & 2,456 & 860 \\
sdadvd01.hdr & Header data & 208,458 & 43,739 \\
sdadvd01.ts & Time series data & $272,793,600$ & $61,778,079$ \\
\hline 5 file(s) & & $273,007,381$ & $61,823,622$ \\
\hline
\end{tabular}


Table 24. Contents of ssadv01.zip, zipped ADV data converted to ASCIl files, Site SS Deployment 1.

\begin{tabular}{llll}
\hline Name & Description of Contents & File Size & $\begin{array}{l}\text { Packed File } \\
\text { Size }\end{array}$ \\
\hline adv-hdr-fmt.txt & Details column headers of .hdr file & 2,262 & 659 \\
adv-ts-fmt.txt & Details column header of .ts file & 605 & 285 \\
ssadvd01.ctl & ADV control file - details sampling scheme and instrument setup & 2,456 & 857 \\
ssadvd01.hdr & Header data & 208,458 & 45,185 \\
ssadvd01.ts & Time series data & $272,793,600$ & $63,501,709$ \\
\hline 5 file(s) & & $273,007,381$ & $63,548,695$ \\
\hline
\end{tabular}

Table 25. Contents of ndadp02.zip, zipped ADP data converted to ASCII files, Site ND Deployment 2.

\begin{tabular}{|c|c|c|c|}
\hline Filename & Description of Contents & File Size & $\begin{array}{l}\text { Packed } \\
\text { File Size }\end{array}$ \\
\hline adp-a-fmt.txt & Details column headers for .a1/.a2/.a3 files & 178 & 140 \\
\hline adp-hdr-fmt.txt & Details column headers for .hdr file & 977 & 343 \\
\hline adp-pts-fmt.txt & Details column headers for .pts file & 172 & 134 \\
\hline adp-sd-fmt.txt & Details column headers for .sd1/.sd2/.sd3 files & 198 & 160 \\
\hline adp-sn-fmt.txt & Details column headers for .sn1/.sn2/.sn3 files & 188 & 146 \\
\hline adp-ve-fmt.txt & Details column headers for .ve file & 187 & 147 \\
\hline adp-vn-fmt.txt & Details column headers for .vn file & 184 & 148 \\
\hline adp-vu-fmt.txt & Details column headers for .vu file & 191 & 151 \\
\hline adp-wav-fmt.txt & Details column headers for wav file & 821 & 249 \\
\hline ndadpd02.a1 & Amplitude of signal strength for beam 1 & 877,144 & 130,183 \\
\hline ndadpd02.a2 & Amplitude of signal strength for beam 2 & 877,144 & 131,379 \\
\hline ndadpd02.a3 & Amplitude of signal strength for beam 3 & 877,144 & 128,236 \\
\hline ndadpd02.ctl & ADP control file - details sampling scheme and instrument setup & 3,865 & 1,324 \\
\hline ndadpd02.hdr & Header data & 319,682 & 43,377 \\
\hline ndadpd02.pts & Pressure time series data & $58,842,624$ & $12,377,817$ \\
\hline ndadpd02.sd1 & Standard deviation of east (magnetic) component of velocity & $1,048,874$ & 116,608 \\
\hline ndadpd02.sd2 & Standard deviation of north (magnetic) component of velocity & $1,048,874$ & 127,089 \\
\hline ndadpd02.sd3 & Standard deviation of vertical component of velocity & $1,048,874$ & 62,845 \\
\hline ndadpd02.sn1 & Signal to noise ratio for beam 1 & $1,048,874$ & 128,317 \\
\hline ndadpd02.sn2 & Signal to noise ratio for beam 2 & $1,048,874$ & 128,623 \\
\hline ndadpd02.sn3 & Signal to noise ratio for beam 3 & $1,048,874$ & 123,907 \\
\hline ndadpd02.ve & East (magnetic) component of velocity & $1,392,334$ & 324,107 \\
\hline ndadpd02.vn & North (magnetic) component of velocity & $1,392,334$ & 336,987 \\
\hline ndadpd02.vu & Vertical (up positive) component of velocity & $1,392,334$ & 243,141 \\
\hline ndadpd02.wav & Wave data & 140,026 & 33,439 \\
\hline 25 file(s) & & $72,410,971$ & $14,438,997$ \\
\hline
\end{tabular}


Table 26. Contents of ndadv02.zip, zipped ADV data converted to ASCII files, Site ND Deployment 2.

\begin{tabular}{llll}
\hline Name & Description of Contents & File Size & $\begin{array}{l}\text { Packed } \\
\text { File Size }\end{array}$ \\
\hline adv-hdr-fmt.txt & Details column headers of .hdr file & 2,262 & 659 \\
adv-ts-fmt.txt & Details column header of .ts file & 605 & 285 \\
ndadvd02.ctl & ADV control file - details sampling scheme and instrument setup & 2,456 & 855 \\
ndadvd02.hdr & Header data & 278,883 & 57,225 \\
ndadvd02.ts & Time series data & $364,953,600$ & $90,262,748$ \\
\hline file(s) & & $365,237,806$ & $90,321,772$ \\
\hline
\end{tabular}

Table 27. Contents of nsadv02.zip, zipped ADV data converted to ASCII files, Site NS Deployment 2.

\begin{tabular}{llll}
\hline Name & Description of Contents & File Size & $\begin{array}{l}\text { Packed File } \\
\text { Size }\end{array}$ \\
\hline adv-ns-hdr-fmt.txt & Details column headers of .hdr file - specific to Site NS & 2,346 & 661 \\
adv-ns-ts-fmt.txt & Details column header of .ts file - specific to Site NS & 538 & 255 \\
nsadvd02.ctl & ADV control file - details sampling scheme and instrument setup & 2,456 & 864 \\
nsadvd02.hdr & Header data & 400,327 & 71,313 \\
nsadvd02.ts & Time series data & $398,147,584$ & $110,578,233$ \\
\hline 5 file(s) & & $398,553,251$ & $110,651,326$ \\
\hline
\end{tabular}

Table 28. Contents of mdadv02.zip, zipped ADV data converted to ASCII files, Site MD Deployment 2.

\begin{tabular}{llll}
\hline Name & Description of Contents & File Size & $\begin{array}{l}\text { Packed File } \\
\text { Size }\end{array}$ \\
\hline adv-hdr-fmt.txt & Details column headers of .hdr file & 2,262 & 659 \\
adv-ts-fmt.txt & Details column header of .ts file & 605 & 285 \\
mdadvd02.ctl & ADV control file - details sampling scheme and instrument setup & 2,455 & 864 \\
mdadvd02.hdr & Header data & 240,071 & 48,764 \\
mdadvd02.ts & Time series data & $314,163,200$ & $75,081,600$ \\
\hline 5 file(s) & & $314,408,593$ & $75,132,172$ \\
\hline
\end{tabular}


Table 29. Contents of mssb02.zip, zipped Seagauge data converted to ASCIl files, Site MS Deployment 2.

\begin{tabular}{llll}
\hline Name & Description of Contents & File Size & $\begin{array}{l}\text { Packed File } \\
\text { Size }\end{array}$ \\
\hline mstidd02.hex & Raw Seagauge ASCll data file & $6,944,493$ & $2,668,527$ \\
mstidd02.tid & Tide data & 229,429 & 46,452 \\
mstidd02.wb & Wave burst data & $14,219,158$ & $3,687,035$ \\
sb-tid-fmt.txt & Details column headers of .tid file & 280 & 191 \\
sb-wb-fmt.txt & Details column headers of .wb file & 524 & 307 \\
\hline 5 file(s) & & $21,393,884$ & $6,402,512$ \\
\hline
\end{tabular}

Table 30. Contents of sdadp02.zip, zipped ADP data converted to ASCII files, Site SD Deployment 2.

\begin{tabular}{|c|c|c|c|}
\hline Filename & Description of Contents & File Size & $\begin{array}{l}\text { Packed } \\
\text { File Size }\end{array}$ \\
\hline adp-a-fmt.txt & Details column headers for .a1/.a2/.a3 files & 178 & 140 \\
\hline adp-hdr-fmt.txt & Details column headers for .hdr file & 977 & 343 \\
\hline adp-pts-fmt.txt & Details column headers for .pts file & 172 & 134 \\
\hline adp-sd-fmt.txt & Details column headers for .sd1/.sd2/.sd3 files & 198 & 160 \\
\hline adp-sn-fmt.txt & Details column headers for .sn1/.sn2/.sn3 files & 188 & 146 \\
\hline adp-ve-fmt.txt & Details column headers for .ve file & 187 & 147 \\
\hline adp-vn-fmt.txt & Details column headers for .vn file & 184 & 148 \\
\hline adp-vu-fmt.txt & Details column headers for .vu file & 191 & 151 \\
\hline adp-wav-fmt.txt & Details column headers for wav file & 821 & 249 \\
\hline sdadpd02.a1 & Amplitude of signal strength for beam 1 & 501,984 & 71,911 \\
\hline sdadpd02.a2 & Amplitude of signal strength for beam 2 & 501,984 & 74,313 \\
\hline sdadpd02.a3 & Amplitude of signal strength for beam 3 & 501,984 & 72,900 \\
\hline sdadpd02.ctl & ADP control file - details sampling scheme and instrument setup & 3,864 & 1,321 \\
\hline sdadpd02.hdr & Header data & 182,952 & 25,428 \\
\hline sdadpd02.pts & Pressure time series data & $33,630,720$ & $7,124,841$ \\
\hline sdadpd02.sd1 & Standard deviation of east (magnetic) component of velocity & 600,264 & 82,137 \\
\hline sdadpd02.sd2 & Standard deviation of north (magnetic) component of velocity & 600,264 & 86,591 \\
\hline sdadpd02.sd3 & Standard deviation of vertical component of velocity & 600,264 & 48,797 \\
\hline sdadpd02.sn1 & Signal to noise ratio for beam 1 & 600,264 & 70,060 \\
\hline sdadpd02.sn2 & Signal to noise ratio for beam 2 & 600,264 & 73,227 \\
\hline sdadpd02.sn3 & Signal to noise ratio for beam 3 & 600,264 & 67,956 \\
\hline sdadpd02.ve & East (magnetic) component of velocity & 796,824 & 195,181 \\
\hline sdadpd02.vn & North (magnetic) component of velocity & 796,824 & 194,455 \\
\hline sdadpd02.vu & Vertical (up positive) component of velocity & 796,824 & 157,718 \\
\hline sdadpd02.wav & Wave data & 80,030 & 19,304 \\
\hline 25 file(s) & & $41,398,670$ & $8,367,758$ \\
\hline
\end{tabular}


Table 31. Contents of sdadv02.zip, zipped ADV data converted to ASCII files, Site SD Deployment 2.

\begin{tabular}{llll}
\hline Name & Description of Contents & File Size & $\begin{array}{l}\text { Packed File } \\
\text { Size }\end{array}$ \\
\hline adv-hdr-fmt.txt & Details column headers of .hdr file & 2,262 & 659 \\
adv-ts-fmt.txt & Details column header of .ts file & 605 & 285 \\
sdadvd02.ctl & ADV control file - details sampling scheme and instrument setup & 2,455 & 861 \\
sdadvd02.hdr & Header data & 236,628 & 48,583 \\
sdadvd02.ts & Time series data & $309,657,600$ & $73,700,098$ \\
\hline 5 file(s) & & $309,899,550$ & $73,750,486$ \\
\hline
\end{tabular}

Table 32. Contents of ssadv02.zip, zipped ADV data converted to ASCII files, Site SS Deployment 2.

\begin{tabular}{llll}
\hline Name & Description of Contents & File Size & $\begin{array}{l}\text { Packed File } \\
\text { Size }\end{array}$ \\
\hline adv-hdr-fmt.txt & Details column headers of .hdr file & 2,262 & 659 \\
adv-ts-fmt.txt & Details column header of .ts file & 605 & 285 \\
ssadvd02.ctl & ADV control file - details sampling scheme and instrument setup & 2,455 & 858 \\
ssadvd02.hdr & Header data & 236,628 & 49,631 \\
ssadvd02.ts & Time series data & $309,657,600$ & $75,024,090$ \\
\hline 5 file(s) & & $309,899,550$ & $75,075,523$ \\
\hline
\end{tabular}




\section{APPENDIX C: DESCRIPTION OF DATA FILES}

The following tables provide a description of the data files recorded by the various instruments. 


\section{C.1 SonTek Hydra System. (SonTek Inc., 1997)}

Table 33. Column headers for ADV .HDR files (except Site NS).

\begin{tabular}{|c|c|c|}
\hline Column \# & Contents & Units \\
\hline 1 & Burst Number & \\
\hline 2 & Year - Start of burst averaging interval & GMT \\
\hline 3 & Month - Start of burst averaging interval & GMT \\
\hline 4 & Day - Start of burst averaging interval & GMT \\
\hline 5 & Hour - Start of burst averaging interval & GMT \\
\hline 6 & Minute - Start of burst averaging interval & GMT \\
\hline 7 & Second - Start of burst averaging interval & GMT \\
\hline 8 & Sampling rate & $\mathrm{Hz}$ \\
\hline 9 & Samples per burst & \\
\hline 10 & Recorded data & \\
\hline 11 & Speed of sound used for velocity computations & $\mathrm{m} / \mathrm{s}$ \\
\hline 12 & Distance to the boundary from probe tip (-0.01 if not detected) & $\mathrm{cm}$ \\
\hline 13 & $\begin{array}{l}\text { Distance to the boundary range from center of sampling volume }(-0.01 \text { if } \\
\text { not detected) }\end{array}$ & $\mathrm{cm}$ \\
\hline 14 & Battery voltage & V \\
\hline 15 & Mean velocity - East & $\mathrm{cm} / \mathrm{s}$ \\
\hline 16 & Mean velocity - North & $\mathrm{cm} / \mathrm{s}$ \\
\hline 17 & Mean velocity - Up & $\mathrm{cm} / \mathrm{s}$ \\
\hline 18 & Mean signal strength - Receiver 1 & counts \\
\hline 19 & Mean signal strength - Receiver 2 & counts \\
\hline 20 & Mean signal strength - Receiver 3 & counts \\
\hline 21 & Mean correlation - Receiver 1 & $\%$ \\
\hline 22 & Mean correlation - Receiver 2 & $\%$ \\
\hline 23 & Mean correlation - Receiver 3 & $\%$ \\
\hline 24 & Mean heading & degrees \\
\hline 25 & Mean pitch & degrees \\
\hline 26 & Mean roll & degrees \\
\hline 27 & Mean temperature & ${ }^{\circ} \mathrm{C}$ \\
\hline 28 & Unused & \\
\hline 29 & Mean Paros & dbar \\
\hline 30 & Mean OBS & counts \\
\hline 31 & Unused & \\
\hline 32 & Standard deviation of velocity - East & \\
\hline 33 & Standard deviation of velocity - North & $\mathrm{cm} / \mathrm{s}$ \\
\hline 34 & Standard deviation of velocity - Up & $\mathrm{cm} / \mathrm{s}$ \\
\hline 35 & Standard deviation of signal strength - Receiver 1 & counts \\
\hline 36 & Standard deviation of signal strength - Receiver 2 & counts \\
\hline 37 & Standard deviation of signal strength - Receiver 3 & counts \\
\hline 38 & Standard deviation of correlation - Receiver 1 & $\%$ \\
\hline 39 & Standard deviation of correlation - Receiver 2 & $\%$ \\
\hline 40 & Standard deviation of correlation - Receiver 3 & $\%$ \\
\hline 41 & Standard deviation of heading & degrees \\
\hline 42 & Standard deviation of pitch & degrees \\
\hline 43 & Standard deviation of roll & degrees \\
\hline 44 & Standard deviation of temperature & ${ }^{\circ} \mathrm{C}$ \\
\hline 45 & Unused & \\
\hline 46 & Standard deviation of Paros & dbar \\
\hline 47 & Standard deviation of OBS & counts \\
\hline 48 & Unused & \\
\hline 49 & Unused & \\
\hline 50 & Unused & \\
\hline 51 & Unused & \\
\hline 52 & Unused & \\
\hline
\end{tabular}


Table 34. Column headers for Site NS ADV .HDR file.

\begin{tabular}{|c|c|c|}
\hline Column \# & Contents & Units \\
\hline 1 & Burst Number & \\
\hline 2 & Year - Start of burst averaging interval & GMT \\
\hline 3 & Month - Start of burst averaging interval & GMT \\
\hline 4 & Day - Start of burst averaging interval & GMT \\
\hline 5 & Hour - Start of burst averaging interval & GMT \\
\hline 6 & Minute - Start of burst averaging interval & GMT \\
\hline 7 & Second - Start of burst averaging interval & GMT \\
\hline 8 & Sampling rate & $\mathrm{Hz}$ \\
\hline 9 & Samples per burst & \\
\hline 10 & Recorded data & \\
\hline 11 & Speed of sound used for velocity computations & $\mathrm{m} / \mathrm{s}$ \\
\hline 12 & Distance to the boundary from probe tip $(-0.01$ if not detected) & $\mathrm{cm}$ \\
\hline 13 & $\begin{array}{l}\text { Distance to the boundary range from center of sampling volume }(-0.01 \text { if } \\
\text { not detected) }\end{array}$ & $\mathrm{cm}$ \\
\hline 14 & Battery voltage & V \\
\hline 15 & Mean velocity - East & $\mathrm{cm} / \mathrm{s}$ \\
\hline 16 & Mean velocity - North & $\mathrm{cm} / \mathrm{s}$ \\
\hline 17 & Mean velocity - Up & $\mathrm{cm} / \mathrm{s}$ \\
\hline 18 & Mean signal strength - Receiver 1 & counts \\
\hline 19 & Mean signal strength - Receiver 2 & counts \\
\hline 20 & Mean signal strength - Receiver 3 & counts \\
\hline 21 & Mean correlation - Receiver 1 & $\%$ \\
\hline 22 & Mean correlation - Receiver 2 & $\%$ \\
\hline 23 & Mean correlation - Receiver 3 & $\%$ \\
\hline 24 & Mean heading & degrees \\
\hline 25 & Mean pitch & degrees \\
\hline 26 & Mean roll & degrees \\
\hline 27 & Mean temperature & ${ }^{\circ} \mathrm{C}$ \\
\hline 28 & Mean pressure & dbar \\
\hline 29 & Unused & \\
\hline 30 & Unused & \\
\hline 31 & Unused & \\
\hline 32 & Standard deviation of velocity - East & $\mathrm{cm} / \mathrm{s}$ \\
\hline 33 & Standard deviation of velocity - North & $\mathrm{cm} / \mathrm{s}$ \\
\hline 34 & Standard deviation of velocity - Up & $\mathrm{cm} / \mathrm{s}$ \\
\hline 35 & Standard deviation of signal strength - Receiver 1 & counts \\
\hline 36 & Standard deviation of signal strength - Receiver 2 & counts \\
\hline 37 & Standard deviation of signal strength - Receiver 3 & counts \\
\hline 38 & Standard deviation of correlation - Receiver 1 & $\%$ \\
\hline 39 & Standard deviation of correlation - Receiver 2 & $\%$ \\
\hline 40 & Standard deviation of correlation - Receiver 3 & $\%$ \\
\hline 41 & Standard deviation of heading & degrees \\
\hline 42 & Standard deviation of pitch & degrees \\
\hline 43 & Standard deviation of roll & degrees \\
\hline 44 & Standard deviation of temperature & ${ }^{\circ} \mathrm{C}$ \\
\hline 45 & Standard deviation of pressure & dbar \\
\hline 46 & Unused & \\
\hline 47 & Unused & \\
\hline 48 & Unused & \\
\hline 49 & Unused & \\
\hline 50 & Unused & \\
\hline 51 & Unused & \\
\hline 52 & Unused & \\
\hline
\end{tabular}


Table 35. Column headers for ADV .TS files (except Site NS) - time series.

\begin{tabular}{lll}
\hline Column \# & \multicolumn{1}{c}{ Contents } & Units \\
\hline 1 & Burst Number & \\
2 & Sample number & \\
3 & Velocity - East & $\mathrm{cm} / \mathrm{s}$ \\
4 & Velocity - North & $\mathrm{cm} / \mathrm{s}$ \\
5 & Velocity - Up & $\mathrm{cm} / \mathrm{s}$ \\
6 & Signal strength - Beam 1 & counts \\
7 & Signal strength - Beam 2 & counts \\
8 & Signal strength - Beam 3 & counts \\
9 & Correlation - Beam 1 & $\%$ \\
10 & Correlation - Beam 2 & $\%$ \\
11 & Correlation - Beam 3 & $\%$ \\
12 & Temperature & ${ }^{\circ} \mathrm{C}$ \\
13 & Unused & \\
14 & OBS & counts \\
15 & Unused & \\
16 & Paros & dbar \\
\hline
\end{tabular}

Table 36. Column headers for Site NS ADV .TS file - time series.

\begin{tabular}{lll}
\hline Column \# & \multicolumn{1}{c}{ Contents } & Units \\
\hline 1 & Burst number & \\
2 & Sample number & \\
3 & Velocity - East & $\mathrm{cm} / \mathrm{s}$ \\
4 & Velocity - North & $\mathrm{cm} / \mathrm{s}$ \\
5 & Velocity - Up & $\mathrm{cm} / \mathrm{s}$ \\
6 & Signal strength - Beam 1 & counts \\
7 & Signal strength - Beam 2 & counts \\
8 & Signal strength - Beam 3 & counts \\
9 & Correlation - Beam 1 & $\%$ \\
10 & Correlation - Beam 2 & $\%$ \\
11 & Correlation - Beam 3 & $\%$ \\
12 & Temperature & ${ }^{\circ} \mathrm{C}$ \\
13 & Pressure & dbar \\
\hline
\end{tabular}




\section{SonTek ADP (SonTek Inc., 1998)}

Table 37. Column headers for ADP .HDR file.

\begin{tabular}{lll}
\hline Column \# & Contents & Units \\
\hline 1 & Profile number & \\
2 & Year - Start of profile averaging interval & GMT \\
3 & Month - Start of profile averaging interval & GMT \\
4 & Day - Start of profile averaging interval & GMT \\
5 & Hour - Start of profile averaging interval & GMT \\
6 & Minute - Start of profile averaging interval & GMT \\
7 & Second - Start of profile averaging interval & GMT \\
8 & Samples averaged this profile & \\
9 & Speed of sound for velocity computations & cm/s \\
10 & Mean heading & degrees \\
11 & Mean pitch & degrees \\
12 & Mean roll & degrees \\
13 & Mean temperature & ${ }^{\circ} \mathrm{C}$ \\
14 & Mean pressure & dBar \\
15 & Standard deviation of heading & degrees \\
16 & Standard deviation of pitch & degrees \\
17 & Standard deviation of roll & degrees \\
18 & Standard deviation of temperature & ${ }^{\circ} \mathrm{C}$ \\
19 & Standard deviation of pressure & dBar \\
20 & Battery Voltage & V \\
\hline
\end{tabular}

Table 38. Column headers for ADP .VE/.VN/.VU files - east (magnetic-eastward positive) / north (magnetic-northward positive) /vertical (up positive) component of velocity for each of 65 cells.

\begin{tabular}{llc}
\hline Column \# & \multicolumn{1}{c}{ Contents } & Units \\
\hline 1 & Profile number & \\
$2-66$ & $\begin{array}{l}\text { Velocity in East/North/Up direction for cells 1-65 (degrees from mag- } \\
\text { netic North) }\end{array}$ & $\mathrm{cm} / \mathrm{s}$ \\
\hline
\end{tabular}

Table 39. Column headers for ADP .SD1/.SD2/.SD3 Files - standard deviation of east / north / vertical component of velocity for each of 65 cells.

\begin{tabular}{lll}
\hline Column \# & \multicolumn{1}{c}{ Contents } & Units \\
\hline 1 & Profile number & \\
$2-66$ & Standard deviation of East/North/Up velocity for cells $1-65$ & $\mathrm{~cm} / \mathrm{s}$ \\
\hline
\end{tabular}

Table 40. Column headers for ADP .A1/.A2/.A3 files - amplitude of signal strength for each beam for each of 65 cells.

\begin{tabular}{llc}
\hline Column \# & \multicolumn{1}{c}{ Contents } & Units \\
\hline 1 & Profile number & \\
$2-66$ & Signal strength for Beam 1/Beam 2/ Beam 3 for cells 1-65 & counts \\
\hline
\end{tabular}


Table 41. Column headers for ADP .SN1/.SN2/.SN3 files - signal to noise ratio for each beam for each of 65 cells.

\begin{tabular}{lll}
\hline Column \# & Contents & Units \\
\hline 1 & Profile number & \\
$2-66$ & Signal to noise ratio for Beam 1/Beam 2/ Beam 3 for cells 1-65 & decibels \\
\hline
\end{tabular}

Table 42. Column headers for ADP.WAV file - wave data.

\begin{tabular}{lll}
\hline Column \# & Contents & Units \\
\hline 1 & Profile number & \\
2 & Estimated wave amplitude for period band: $2-4 \mathrm{~s}$ & $\mathrm{~cm}$ \\
3 & Estimated wave amplitude for period band: $4-6 \mathrm{~s}$ & $\mathrm{~cm}$ \\
4 & Estimated wave amplitude for period band: $6-8 \mathrm{~s}$ & $\mathrm{~cm}$ \\
5 & Estimated wave amplitude for period band: $8-10 \mathrm{~s}$ & $\mathrm{~cm}$ \\
6 & Estimated wave amplitude for period band: $10-12 \mathrm{~s}$ & $\mathrm{~cm}$ \\
7 & Estimated wave amplitude for period band: $12-14 \mathrm{~s}$ & $\mathrm{~cm}$ \\
8 & Estimated wave amplitude for period band: $14-16 \mathrm{~s}$ & $\mathrm{~cm}$ \\
9 & Estimated wave amplitude for period band: $16-18 \mathrm{~s}$ & $\mathrm{~cm}$ \\
10 & Estimated wave amplitude for period band: $18-20 \mathrm{~s}$ & $\mathrm{~cm}$ \\
11 & Estimated wave amplitude for period band: $20-\mathrm{more} \mathrm{s}$ & $\mathrm{cm}$ \\
12 & Significant wave height for profile & $\mathrm{cm}$ \\
13 & Mean period for profile & $\mathrm{s}$ \\
\hline
\end{tabular}

Table 43. Column headers for ADP .PTS file - pressure time series.

\begin{tabular}{llc}
\hline Column \# & Contents & Units \\
\hline 1 & Profile number at which time series was started & psia \\
$2-9$ & Pressure & P \\
\hline
\end{tabular}

\section{C.2 Sea-Bird Seagauge Wave and Tide Recorder. (Sea-Bird Electronics, Inc., 2000b)}

Table 44. Column headers for Seagauge .TID files- tide data.

\begin{tabular}{lll}
\hline Column \# & Contents & Units \\
\hline 1 & Tide measurement number & \\
2 & MM/DD/YY & GMT \\
3 & HHMM:SS & GMT \\
4 & Mean pressure & psia \\
5 & Mean temperature & ${ }^{\circ} \mathrm{C}$ \\
\hline
\end{tabular}


Table 45. Column headers for Seagauge .WB files - wave burst data.

\begin{tabular}{lll}
\hline Column \# & \multicolumn{1}{c}{ Contents } & Units \\
\hline The following repeats every 301 lines: & \\
$1^{\text {st }}$ Line & ${ }^{*}$ - flags beginning of wave burst data & \\
1 & Wave burst number & \\
2 & Start of burst measurement & seconds since Jan. 1, 1989 \\
3 & Wave integration period & $\mathrm{s}$ \\
4 & Number of measurements in burst & \\
5 & & psia \\
Next 300 Lines & Pressure & \\
$1-4$ & &
\end{tabular}




\section{APPENDIX D: OBS CALIBRATION}

This appendix describes laboratory calibrations for the Hydra data logger and the OBS sensors.

\section{D.1 Voltage to Counts Conversion}

Optical backscatter sensors (OBS) measure turbidity and suspended solids concentrations by detecting infrared radiation scattered from suspended matter in a small sampling volume (D\&A Instrument Co., 1991). The OBS outputs a voltage between 0 to $5 \mathrm{~V}$ in response to the amount of light scattered. The OBS output voltage is converted by an analog-to-digital (A/D) converter in the Hydra system and recorded in counts as values between 0 and 65535 (SonTek Inc., 1997).

Calibration of the A/D converter was performed in the laboratory. The output in counts was recorded for applied voltages of $0.0,1.0,2.0,3.0,4.0$ and 5.0 Volts and a line was fit to the data, where counts $=A \cdot$ volts $+B$. The results of the calibrations are reported for each Hydra with an OBS (Table 46). The serial numbers of the OBS can be found in Table 3. Results for Site NS have been omitted since no OBS data were retrieved from that location.

Table 46. Response of Hydra system to increased voltage.

\begin{tabular}{llllll}
\hline Site & $\begin{array}{l}\text { Hydra } \\
\text { S/N }\end{array}$ & $\begin{array}{l}\boldsymbol{A} \\
\text { (counts/V) }\end{array}$ & $\begin{array}{l}\boldsymbol{B} \\
\text { (counts) }\end{array}$ & $\mathbf{R}^{2}$ & $\begin{array}{l}\text { \# of Data } \\
\text { Points }\end{array}$ \\
\hline ND & B45 & 12754 & 112.76 & 0.999990 & 6 \\
MD & B51 & 12757 & 164.57 & 0.999979 & 6 \\
SD & B52 & 12766 & 153.9 & 0.999962 & 6 \\
SS & B59 & 12771 & 213.33 & 0.999987 & 6 \\
\hline
\end{tabular}

The above equations were rearranged to convert the OBS data from counts to volts.

\section{D.2 Formazin Calibration}

Calibrations of OBS response to turbidity was performed in the laboratory. Solutions of Formazin (4000 NTU stock solution) and 0.2 micropore filtered deionized water (which had been left to degas for at least an hour) were mixed to concentrations of $0.00,17.51,100.24$ and 397.49 NTU. A round yellow $\sim 20 \mathrm{~L}$ container was used for the 0 NTU solution and $7.3 \mathrm{~L}$ dark green rectangular Rubbermaid containers were used for the remaining solutions. The dark color minimized reflection of the infrared light emitted by the OBS off the walls of the container. We found that larger containers are necessary for lower NTU concentrations because the light is less obstructed and, therefore, travels further.

Each OBS was positioned in the containers with the sensor a minimum of $5 \mathrm{~cm}$ from the surface of the solution and the bottom of the container. The sensor was directed towards the furthest corner of the container.

To perform the Formazin calibrations, a 12-Volt battery was used to power the OBS. The output of the OBS was sent to a Protek 506 Digital Multi-meter (DMM). The software supplied with the multimeter calculated the minimum, maximum and average of the OBS output voltage. It also allowed the output to be logged to a data file. Sampling was at a rate of $1 \mathrm{~Hz}$.

The minimum, maximum and, 30 second averages were recorded for each OBS at each Formazin concentration. 
The average voltage for each concentration was used to find a linear relationship between Formazin concentration and the voltage outputted by the OBS. These calibration equations, where volts $=C$.counts $+D$, can be found in Table 47 .

Table 47. OBS calibration equations from Formazin calibrations.

\begin{tabular}{llllll}
\hline Site & $\begin{array}{l}\text { Hydra } \\
\text { S/N }\end{array}$ & $\begin{array}{l}\boldsymbol{C} \\
\text { (V/NTU) }\end{array}$ & $\begin{array}{l}\boldsymbol{D} \\
\text { (V) }\end{array}$ & $\mathbf{R}^{2}$ & $\begin{array}{l}\text { \# of Data } \\
\text { Points }\end{array}$ \\
\hline ND & B45 & 0.010116 & 0.010588 & 0.999994 & 4 \\
MD & B51 & 0.010137 & 0.014803 & 0.999978 & 4 \\
SD & B52 & 0.010143 & 0.009100 & 0.999979 & 4 \\
SS & B59 & 0.010219 & 0.012569 & 0.999952 & 4 \\
\hline
\end{tabular}

The above equations were rearranged to convert the OBS data to turbidity measurements. 